UNIVERSIDADE DE SÃO PAULO

FACULDADE DE ECONOMIA, ADMINISTRAÇÃO E CONTABILIDADE DEPARTAMENTO DE ADMINISTRAÇÃO PROGRAMA DE PÓS-GRADUAÇÃO EM ADMINISTRAÇÃO

A INFLUÊNCIA DA TRANSFERÊNCIA DE CONHECIMENTO E DE FATORES CULTURAIS NA INICIATIVA DAS SUBSIDIÁRIAS DE MULTINACIONAIS BRASILEIRAS

Natacha Bertoia da Silva

Orientadora: Prof ${ }^{a}$. Dr ${ }^{\mathrm{a}}$. Maria Tereza Leme Fleury

SÃo PAULO 
Prof. Dr. João Grandino Rodas Reitor da Universidade de São Paulo

Prof. Dr. Reinaldo Guerreiro

Diretor da Faculdade de Economia, Administração e Contabilidade

Prof. Dr. Adalberto Américo Fischmann

Chefe do Departamento de Administração

Prof. Dr. Lindolfo Galvão de Albuquerque

Coordenador do Programa de Pós-Graduação em Administração 
NATACHA BERTOIA DA SILVA

\title{
A INFLUÊNCIA DA TRANSFERÊNCIA DE CONHECIMENTO E DE FATORES CULTURAIS NA INICIATIVA DAS SUBSIDIÁRIAS DE MULTINACIONAIS BRASILEIRAS
}

\begin{abstract}
Tese apresentada ao Departamento de Administração da Faculdade de Economia, Administração e Contabilidade como requisito para a obtenção do título de Doutor em Administração
\end{abstract}

Orientadora: Prof ${ }^{a}$. Dra . Maria Tereza Leme Fleury

São Paulo 


\section{FICHA CATALOGRÁFICA}

Elaborada pela Seção de Processamento Técnico do SBD/FEA/USP

Silva, Natacha Bertoia da

A influência da transferência de conhecimento e de fatores culturais

na iniciativa das subsidiárias de multinacionais brasileiras / Natacha Bertoia da Silva. - São Paulo, 2010.

$229 \mathrm{p}$.

Tese (Doutorado) - Universidade de São Paulo, 2010.

Orientador: Maria Tereza Leme Fleury.

1. Internacionalização de empresas 2. Empresas multinacionais 3. Cultura I. Universidade de São Paulo. Faculdade de Economia, Administração e Contabilidade. II. Título.

$$
\text { CDD }-658.409
$$


À minha avó Edy Maya Bertoia, in memoriam, pelo vigor presente durante sua vida.

Ao Vicente Calvo, sempre companheiro. 


\section{AGRADECIMENTOS}

A elaboração de uma tese, entre diversos risos e algumas lágrimas, é um aprendizado constante, sendo o desenvolvimento solitário um dos maiores desafios do processo. No entanto, apesar de ser uma atividade individual, pude contar com o auxílio de diversas pessoas, fundamentais para a concretização deste objetivo pessoal e profissional, que menciono os meus profundos agradecimentos.

À Prof ${ }^{a}$. Dr ${ }^{a}$. Maria Tereza Leme Fleury, por incentivar o meu desenvolvimento enquanto pesquisadora, docente e no doutorado, principalmente, por sua importante orientação e valorização sempre presentes, indicando o caminho nos momentos mais difíceis desta jornada. Aos demais docentes da FEA-USP, que contribuíram para a minha formação acadêmica desde a graduação, em especial aos professores da área de gestão de pessoas.

À Cristina Marselha e à Regina de Almeida, pelo sempre pronto atendimento e valiosos suportes. Aos funcionários do Departamento de Pós-Graduação e da Biblioteca, atenciosos e disponíveis às minhas solicitações.

Aos meus colegas docentes na Universidade Presbiteriana Mackenzie, em especial ao Prof. Dr. Adilson Aderito da Silva, Prof. Dr. Diógenes de Souza Bido, Prof. Dr. David Pires Dias, Prof. Dr. Saulo Soares de Souza e Prof ${ }^{\mathrm{a}}$. Dra . Arilda Schmidt Godoy, que me auxiliaram tecnicamente em vários momentos da elaboração da tese. Agradeço também a $\operatorname{Prof}^{\mathrm{a}} \operatorname{Dr}^{\mathrm{a}}$. Andresa Silva Neto Francischini, Prof. Dr. Arnaldo Turuo Ono, Prof. Dr. José Carlos Thomaz e demais professores do Campus Tamboré, pelo apoio neste período.

À Prof ${ }^{a}$. Tatiana Iwai, coordenadora da Escola Superior de Administração e Gestão, pela compreensão e auxílio durante toda a jornada.

Aos profissionais que contribuíram muito com suas competências técnicas. À Fanny Mori, pelo auxílio nas análises estatísticas. Ao Thales Sakamoto, pela dedicação e competência no levantamento de dados secundários importantes para o estudo. À Cintia Nassar, pelo eficiente trabalho na transcrição das entrevistas.

Aos amigos competentes e dispostos seriamente em ajudar. Ao Pedro Antonelli, pela paciência e boa vontade na viabilização do questionário on-line para que pudesse ser respondido pelos diretores de unidades distantes geograficamente. Ao Rogério Bruno, pela dedicação e empenho na leitura crítica do trabalho, indicando sugestões de melhorias. À Danielle Guglieri Lima, pela competência e valiosas contribuições linguísticas para a clareza das ideias do texto. 
Aos colegas e amigos do doutorado, especialmente a Liliana Vasconcellos, Ademar Orsi, Lina Nakata, Dinora Floriani, Patricia Muritiba, Sergio Muritiba e Felipe Borini.

À empresa Weg S.A., pela possibilidade de efetuar o estudo, fortalecendo a análise proposta da pesquisa. Agradeço, particularmente, ao Sr. Roberto Lourenço, que cordialmente me atendeu e facilitou todo o processo de interface com as unidades exteriores da empresa e, a atenção dedicada pelos diretores das unidades exteriores e o gerente de exportação na matriz. Aos meus amigos, pelos estímulos constantes e compreensão sobre o meu afastamento durante a longa empreitada da tese.

À minha irmã, Hanuska, pelas dicas fundamentais nos últimos momentos.

Aos meus pais, Luiz Alberto e Soila, pela paciência nas minhas ausências neste período e pelas palavras motivadoras e permanentes para que eu conseguisse concluir a tese com êxito. Ao querido Vicente Calvo, especialmente, pela serenidade e companheirismo, auxílio inquestionável às minhas indagações, carinho e compreensão nos momentos mais árduos desta jornada. 
"As pessoas sempre culpam as circunstâncias pelo que são. Eu não acredito nas circunstâncias. A pessoa que progride neste mundo é aquela que persegue e busca as circunstâncias que deseja e, se não as encontra, as cria."

George Bernard Shaw 


\section{RESUMO}

Diante do processo recente da internacionalização das empresas brasileiras, que ainda suscita estudos para melhor compreender a dinâmica e o estabelecimento dos entrantes tardios verdeamarelos em todos os continentes e, visto que os estudos sobre subsidiárias de multinacionais brasileiras ainda são incipientes, o objetivo geral desta pesquisa foi analisar a influência da transferência de conhecimento e de fatores culturais na iniciativa das subsidiárias de multinacionais brasileiras. A partir das reflexões acerca dos estudos sobre matrizes e subsidiárias de multinacionais, sobretudo aqueles relacionados à cultura, transferência de conhecimento e iniciativa, as três hipóteses deste estudo emergiram e; baseado no modelo de iniciativa da subsidiária de Birkinshaw (1999), o modelo desta pesquisa foi explicitado considerando o contexto corporativo e o local da subsidiária, configurados por dimensões predominantemente comportamentais. Em termos metodológicos, empregou-se a estratégia sequencial explanatória, caracterizada pela coleta e análise de dados quantitativos seguido pela coleta e análise de dados qualitativos. Na primeira etapa, utilizou-se de técnicas estatísticas para analisar uma amostra de 66 subsidiárias de multinacionais brasileiras; enquanto na segunda etapa, explorou-se os resultados obtidos por meio de uma abordagem qualitativa aplicada na Weg, multinacional brasileira, envolvendo a matriz e as respectivas subsidiárias. Como principais resultados, constatou-se que a transferência de conhecimento nas multinacionais brasileiras parte na maioria dos casos, da matriz para subsidiária, principalmente com as unidades oriundas de processos de aquisição, evidenciando o compartilhamento do conhecimento tácito por meio do processo de socialização. Ambas as etapas da pesquisa permitiram identificar que algumas características culturais brasileiras estão presentes nas subsidiárias, principalmente as relacionadas à questão do poder, centralização e hierarquia, que podem dificultar o processo de transferência de conhecimento. Em relação ao modelo de pesquisa proposto, foi possível validá-lo na etapa quantitativa, visto que este explicou $28,9 \%$ da variabilidade da iniciativa da subsidiária de multinacional brasileira, considerado um resultado satisfatório nos estudos de ciências sociais. Duas, das três hipóteses verificadas, foram confirmadas: a iniciativa da subsidiária é diretamente influenciada pela transferência de conhecimento e esta, por sua vez, influenciado pela cultura. Entretanto, a influência da cultura na iniciativa da subsidiária não foi confirmada pela amostra do estudo, mas indícios da sua importância foram percebidos. O estudo sobre a Weg, na segunda fase da pesquisa, permitiu ilustrar o modelo proposto. Por fim, inspirado em uma proposta semelhante de Birkinshaw (1995), considerando-se a transferência de conhecimento, a cultura e a iniciativa das unidades, definiu-se três conglomerados de subsidiárias: Iniciativa de reconfiguração, Iniciativa no mercado local e Iniciativa incipiente. Como contribuições, destacam-se o enriquecimento da literatura acadêmica em construção sobre as multinacionais brasileiras, principalmente o olhar da iniciativa das subsidiárias; a definição de um modelo teórico com variáveis predominantemente comportamentais e que pode ser validado; e reflexões sobre a atuação das multinacionais brasileiras no contexto internacional. Para estudos futuros, acredita-se que outras variáveis sejam incorporadas ao modelo de pesquisa e que este seja aplicado novamente às subsidiárias de multinacionais brasileiras, permitindo uma análise longitudinal, bem como em realidades de outros países. Também, visando aprofundar a interpretação dos dados resultantes da etapa quantitativa, a realização de pesquisas em outras multinacionais brasileiras utilizando a abordagem qualitativa como na segunda fase deste estudo será relevante. 


\begin{abstract}
The internationalization of Brazilian companies is a recent process and raises the need for studies to better understand the dynamic and establishment of Brazilian late-movers in other continents. Moreover, the studies on Brazilian multinational subsidiaries are still scarce. As a result, the general goal of this research was to analyze the influence of knowledge transfer and cultural factors in initiatives of Brazilian multinational subsidiaries. The three hypothesis of this study emerged from the studies about headquarters and subsidiaries of multinationals, mainly those related to culture, knowledge transfer, and initiative. Based on Birkinshaw's (1999) model of subsidiary initiative, this research's model was depicted and it considered both the corporate context and the location of the subsidiary. These issues were especially set by behavioral dimensions. Regarding methodological issues, the explanatory sequential strategy was employed. This strategy includes collecting and analyzing quantitative data and, then, collecting and analyzing qualitative data. At the first phase of the research, statistical techniques were used to analyze a sample of 66 Brazilian multinational subsidiaries. At the second phase, results were obtained and analyzed through a more qualitative approach at Weg, a Brazilian multinational, including headquarters and subsidiaries. As main findings, it has been noticed that knowledge transfer in Brazilian multinationals, mostly, occurs from headquarter to the subsidiary and it is especially true when these subsidiaries are resulted from an acquisition. It was noticed that tacit knowledge sharing occurs through the socialization process. Results depicted from both phases of the research unveiled that some Brazilian cultural features are present in the subsidiaries, especially those related to power, centralization, and hierarchy. These issues can hamper the knowledge transfer process. It was possible to validate the proposed model since it explained $28.9 \%$ of the Brazilian multinational subsidiary initiative variability. This number is considered satisfactory for studies in Social Sciences. Two out of the three tested hypothesis were confirmed: the initiative of the subsidiary is directly influenced by knowledge transfer, which is, then, influenced by culture. However, although the influence of culture in the initiative of the subsidiary was not confirmed with this study's sample, there is evidence it is important. The study at Weg, at the second phase of this research, was useful to put the proposed model into practice. Inspired by a proposal similar to Birkinshaw's (1995) model and considering knowledge transfer, culture, and initiatives of units, three subsidiary clusters were defined: (1) reconfiguration initiative, (2) local market initiative, and (3) incipient initiative. Contributions of this study include: (1) enriching the under-construction academic literature by studying Brazilian multinationals and focused on the initiative of subsidiaries, (2) defining a theoretical model with predominantly behavioral variables, (3) validating the model, and (4) discussing the operation of Brazilian multinationals within the international context. Future studies should include other variables into the research model, which may be reapplied at Brazilian multinational subsidiaries. It will enable researchers to both promote a longitudinal analysis and to understand the reality of other countries. Moreover, aiming at deepening the interpretation of data from the quantitative phase, it is relevant to conduct research at other Brazilian multinationals and the approach should be qualitative, likewise the second phase of this study.
\end{abstract}




\section{SUMÁRIO}

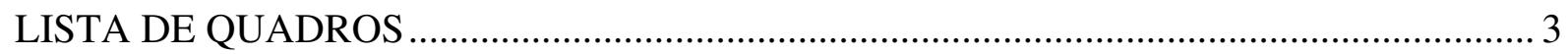

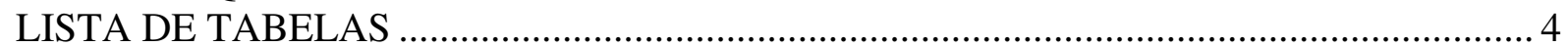

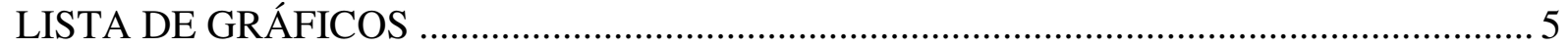

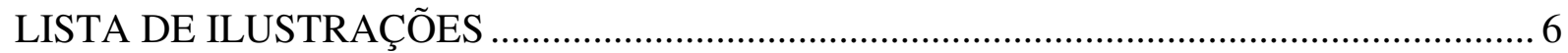

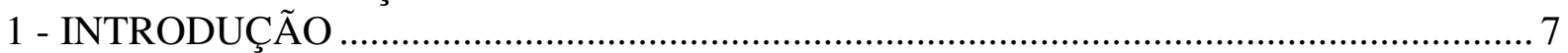

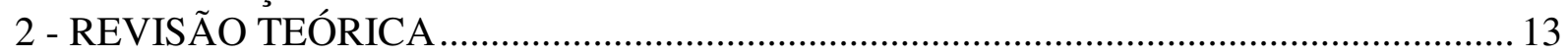

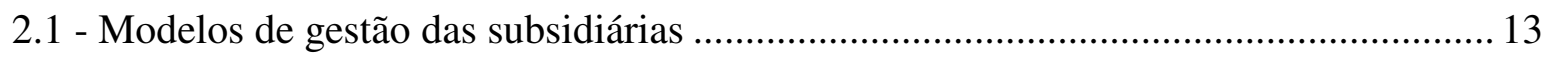

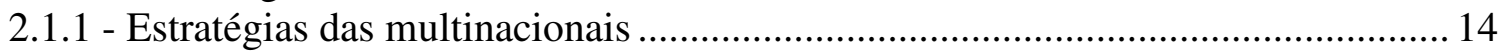

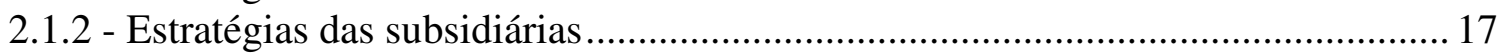

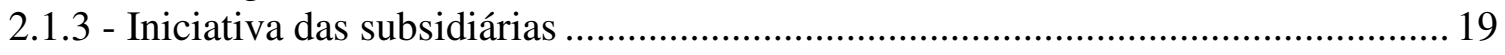

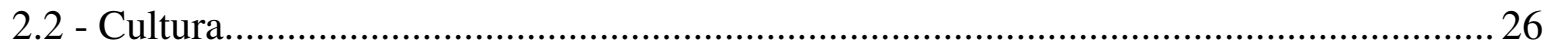

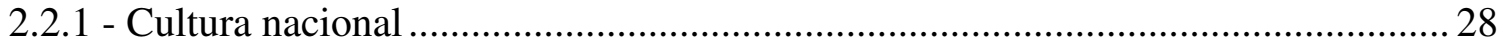

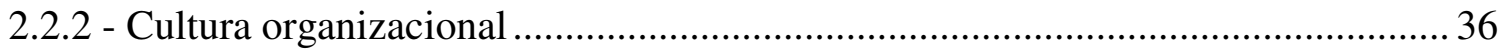

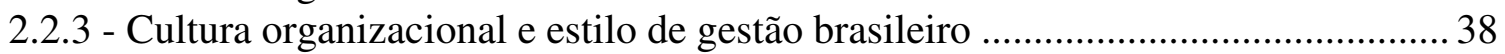

2.3 - Transferência de conhecimento em multinacionais .................................................... 41

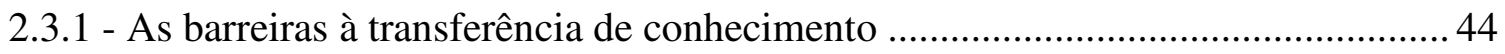

2.3.2 - A estratégia de entrada e a transferência de conhecimento .................................. 47

2.3.3 - A cultura nacional e a transferência de conhecimento............................................ 49

3 - FORMULAÇÃO DAS HIPÓTESES E O MODELO DE PESQUISA............................... 55

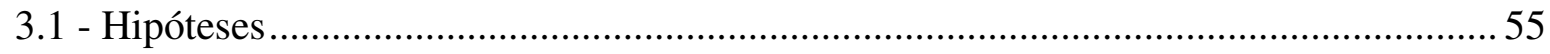

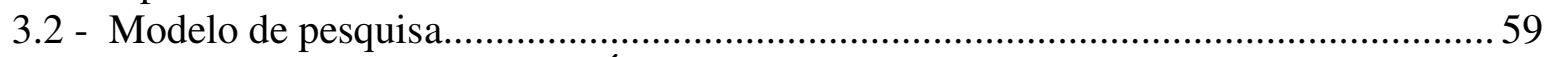

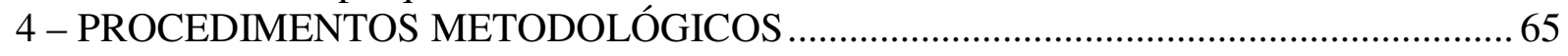

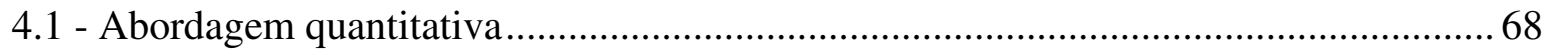

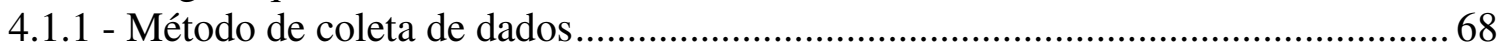

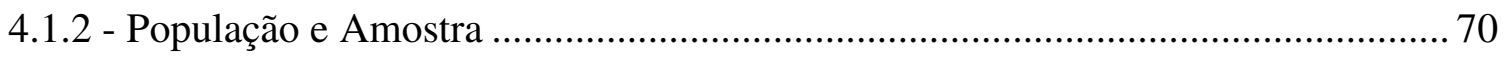

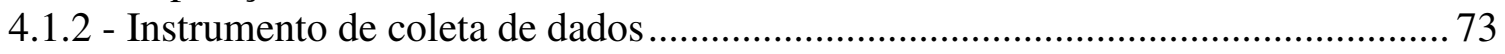

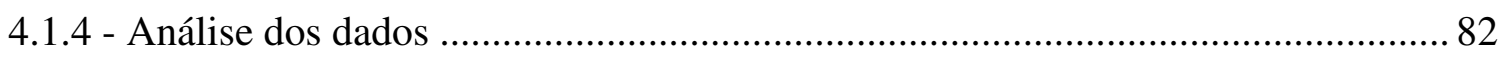

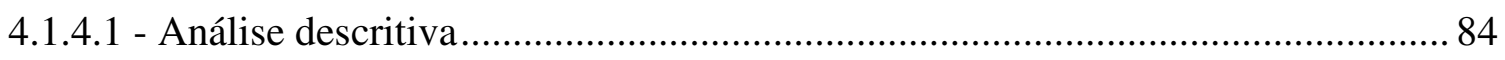

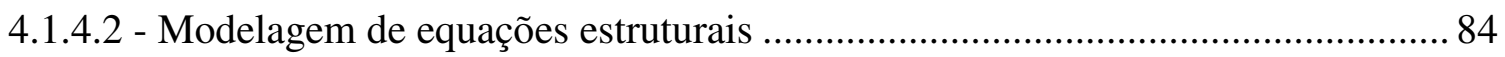

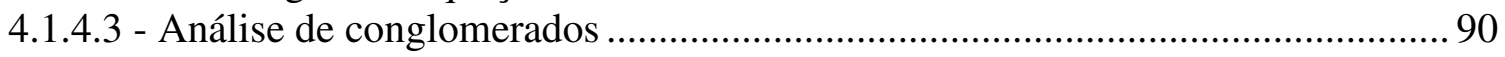

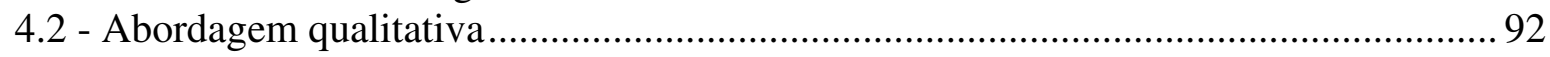

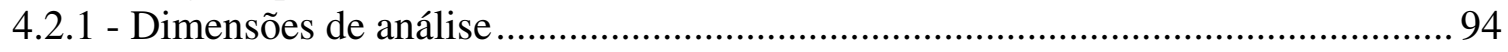

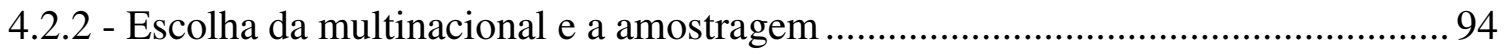

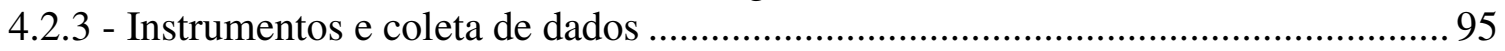

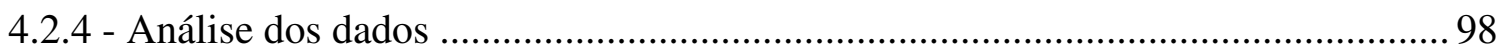

5 - APRESENTAÇÃO E ANÁLISE DOS RESULTADOS QUANTITATIVOS ................ 101

5.1 - O processo de transferência de conhecimento entre a subsidiária e a matriz ............. 101

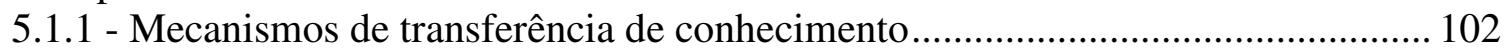

5.1.1.1 - Síntese sobre os mecanismos de transferência de conhecimento ....................... 106

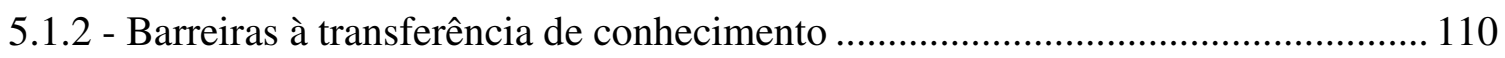

5.1.2.1 - Síntese sobre as barreiras à transferência de conhecimento ............................. 113

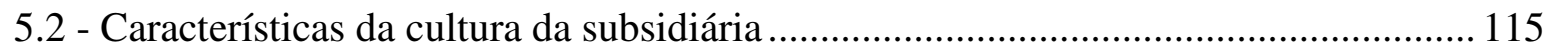

5.2.1 - Formação e caracterização dos conglomerados de cultura nacional ................... 116

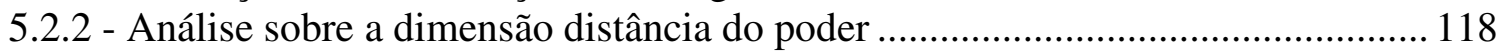

5.2.3 - Análise sobre a dimensão individualismo.......................................................... 121

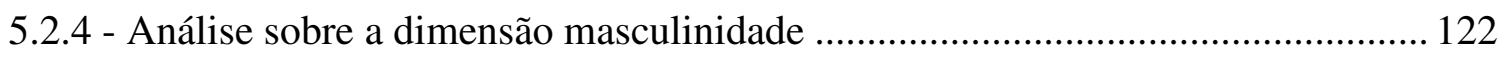

5.2.5 - Análise sobre a dimensão controle das incertezas ........................................... 124 


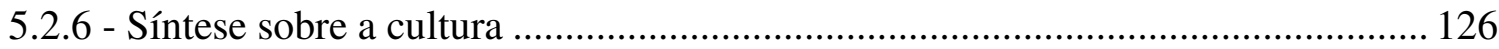

5.3 - A influência da cultura e da transferência de conhecimento na iniciativa da subsidiaria.

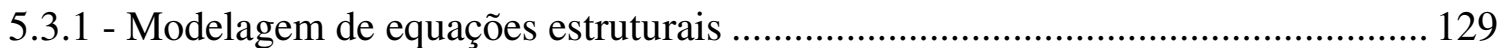

5.3.1.1 - Avaliação do modelo de mensuração ................................................................. 133

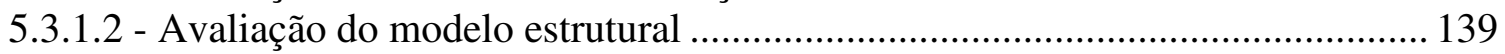

5.3.2 - Análise dos resultados da modelagem de equações estruturais ........................... 141

5.4 - Configuração de grupos homogêneos de subsidiárias a partir da cultura, transferência

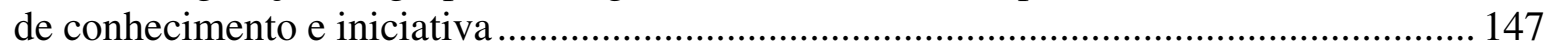

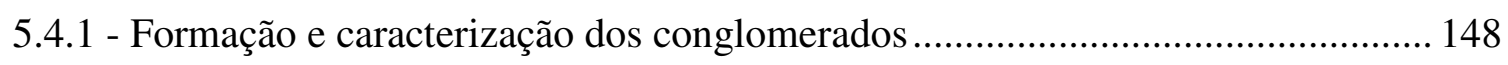

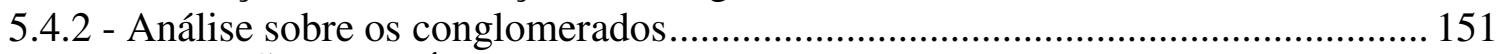

6 - APRESENTAÇÃO E ANÁLISE DOS RESULTADOS QUALITATIVOS .................... 157

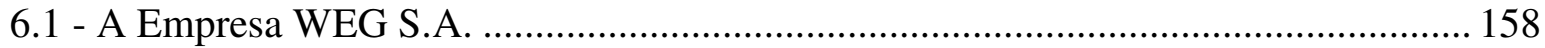

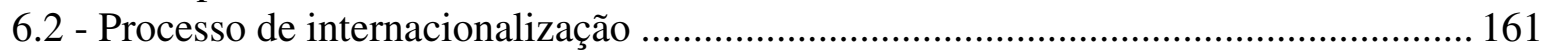

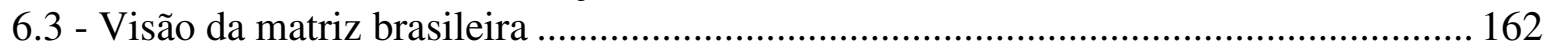

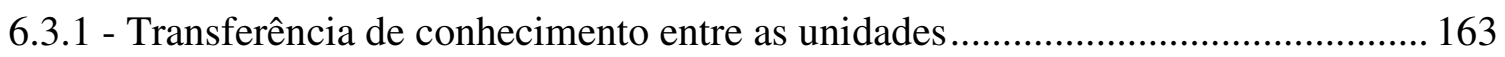

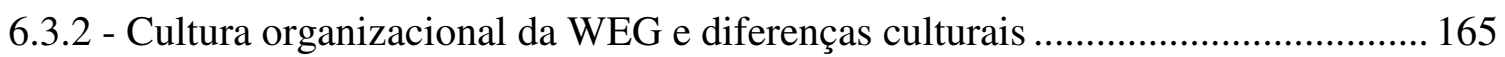

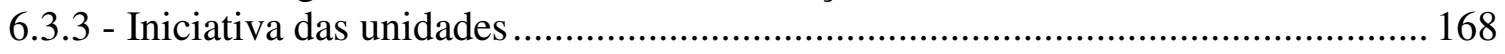

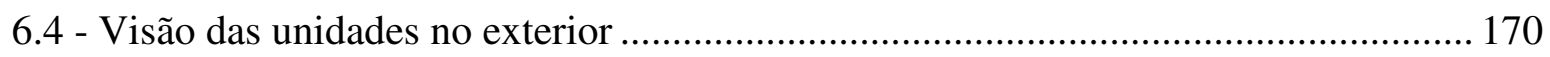

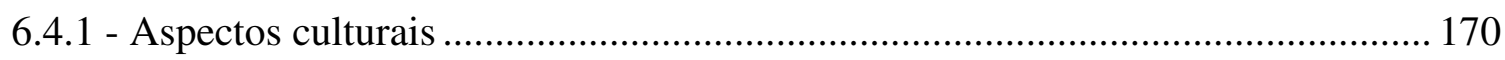

6.4.2 - Transferência de conhecimento entre as unidades ........................................... 173

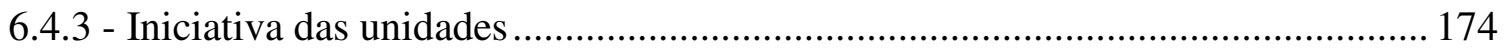

6.5 - Análise comparativa dos resultados da WEG ........................................................... 178

7- DISCUSSÃO DOS RESULTADOS QUANTITATIVOS E QUALITATIVOS .............. 185

7.1 - O processo de transferência de conhecimento entre a subsidiária e a matriz ............ 185

7.2 - Características da cultura da subsidiária ...................................................................... 189

7.3 - A influência da cultura e da transferência de conhecimento na iniciativa da

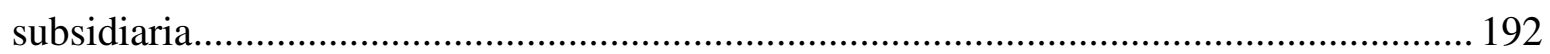

7.4 - Configuração de grupos homogêneos de subsidiárias a partir da cultura, transferência

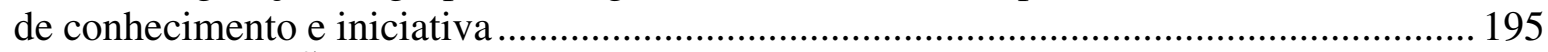

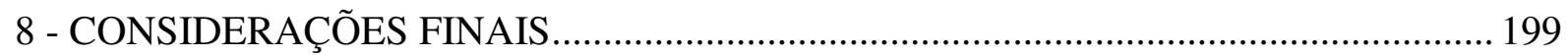

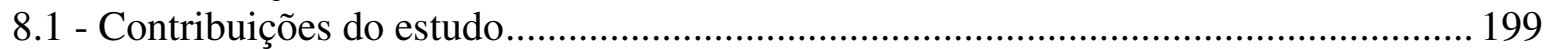

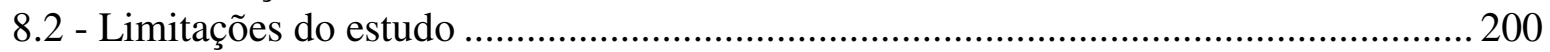

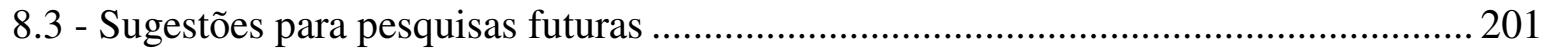

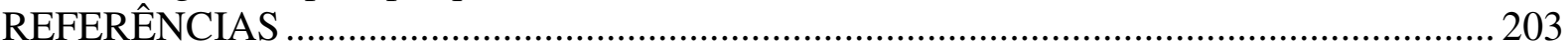

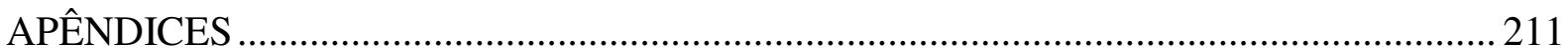

ANEXOS 


\section{LISTA DE QUADROS}

Quadro 1 - Principais linhas de pesquisas na gestão de subsidiárias ...................................... 9

Quadro 2 - Características Organizacionais das Corporações Multinacionais ......................... 14

Quadro 3 - Semelhanças de conceitos de estratégias em negócios internacionais.................... 16

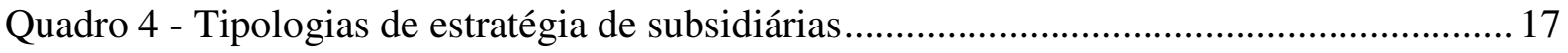

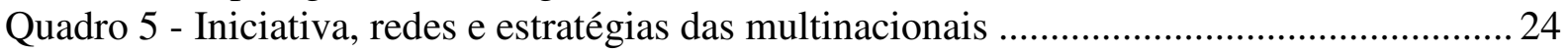

Quadro 6 - Características das iniciativas das subsidiárias .....................................................26

Quadro 7 - A dimensão distância do poder no ambiente de trabalho ...................................... 31

Quadro 8 - Principais características culturais das regiões brasileiras .................................... 35

Quadro 9 - Métodos de entrada no mercado global ............................................................... 47

Quadro 10 - Principais características da transferência de conhecimento em relação a forma de

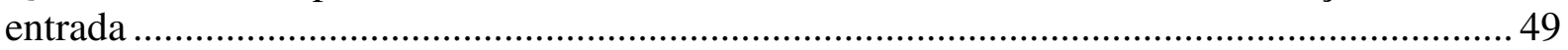

Quadro 11 - Síntese das principais ideias referentes à iniciativa da subsidiária ........................52

Quadro 12 - Síntese das principais ideias referentes à transferência de conhecimento ...........53

Quadro 13 - Síntese das principais ideias referentes à cultura ............................................ 54

Quadro 14 - Principais vantagens e desvantagens das surveys auto-administradas ................69 69

Quadro 15 - Construtos e variáveis relacionadas à transferência de conhecimento .................77

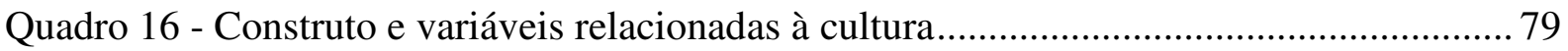

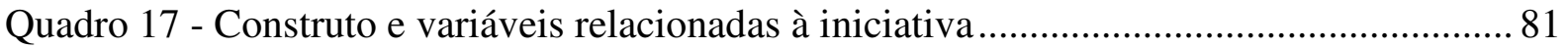

Quadro 18 - Objetivos específicos e técnicas de análise estatística ....................................... 83

Quadro 19 - Diferenças entre a MEEPLS e MEEBC............................................................ 88

Quadro 20 - Dimensões e questões norteadoras da etapa qualitativa ..................................... 94

Quadro 21 - Técnicas e fontes de coletas de dados qualitativos .......................................... 95

Quadro 22 - Síntese dos principais mecanismos de transferência de conhecimento ............. 109

Quadro 23 - Síntese das principais barreiras à transferência de conhecimento ..................... 115

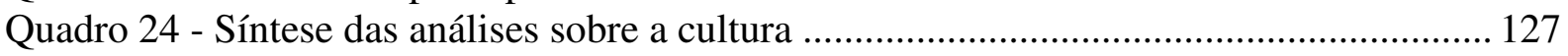

Quadro 25 - Síntese das hipóteses e variáveis do modelo................................................... 129

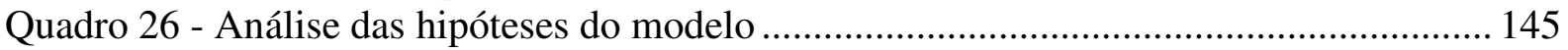

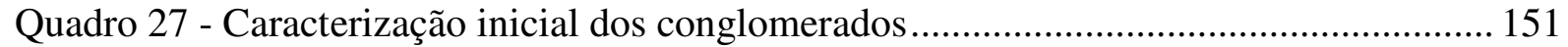

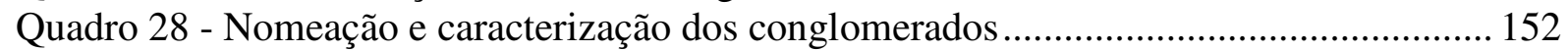

Quadro 29 - Sínteses sobre a visão da matriz da multinacional brasileira ............................ 170

Quadro 30 - Síntese sobre a visão das subsidiárias da multinacional brasileira .................... 178

Quadro 31 - Processo de transferência de conhecimento entre a subsidiária e a matriz........ 188

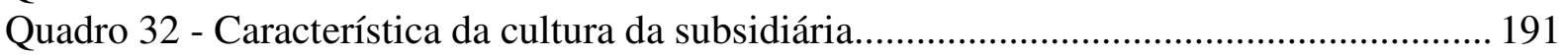

Quadro 33 - Influência da cultura e da transferência de conhecimento na iniciativa da

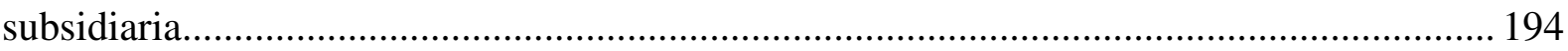

Quadro 34 - Configuração de grupos homogêneos de subsidiária........................................ 197 
LISTA DE TABELAS

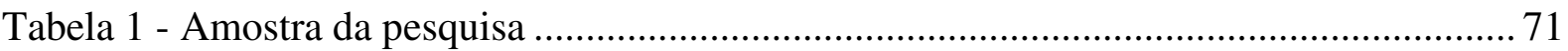

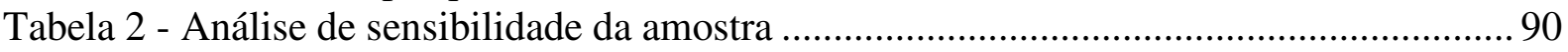

Tabela 3 - Mecanismos de transferência de conhecimento utilizados pelas multinacionais

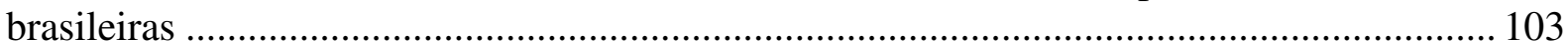

Tabela 4 - Barreiras na transferência de conhecimento nas multinacionais brasileiras .......... 111

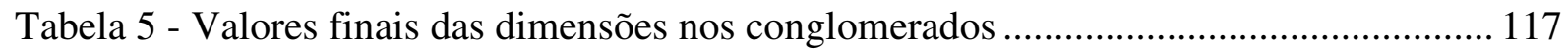

Tabela 6 - Análise da variância referente aos conglomerados de cultura .............................. 117

Tabela 7 - Distribuição das subsidiárias por conglomerado ................................................ 118

Tabela 8 - Resultados referentes à dimensão distância do poder ........................................ 119

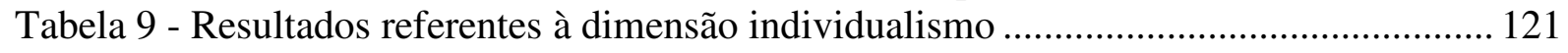

Tabela 10 - Resultados referentes à dimensão masculinidade .......................................... 123

Tabela 11 - Resultados referentes à dimensão controle de incertezas .................................. 125

Tabela 12 - Indicadores retirados do modelo por apresentarem carga fatorial menor que

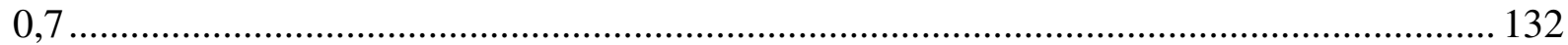

Tabela 13 - Valores da AVE e confiabilidade composta ................................................ 135

Tabela 14 - Indicadores e suas respectivas cargas cruzadas do modelo final ....................... 137

Tabela 15 - Correlação entre as variáveis latentes (Modelo de mensuração final) ................ 138

Tabela 16 - Análise da variância dos conglomerados em relação à iniciativa da subsidiária 150

Tabela 17 - Distribuição das subsidiárias nos conglomerados............................................ 150

Tabela 18 - Valores finais das variáveis nos três conglomerados....................................... 150 


\section{LISTA DE GRÁFICOS}

Gráfico 1 - Distribuição da amostra em relação aos setores de atuação ................................. 72

Gráfico 2 - Distribuição da amostra em relação ao continente …........................................... 72

Gráfico 3 - Distribuição da amostra em relação a forma de criação da subsidiária ................. 73

Gráfico 4 - Número de colaboradores da Weg S.A. no âmbito mundial ................................ 159

Gráfico 5 - Faturamento anual da Weg S.A. (em milhões de R\$) ........................................ 159 


\section{LISTA DE ILUSTRAÇÕES}

Ilustração 1 - Modelo do contexto organizacional e a iniciativa da subsidiária ...................... 21

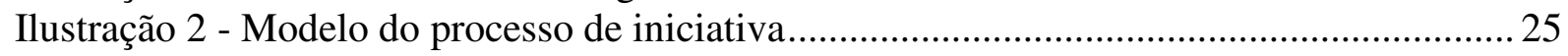

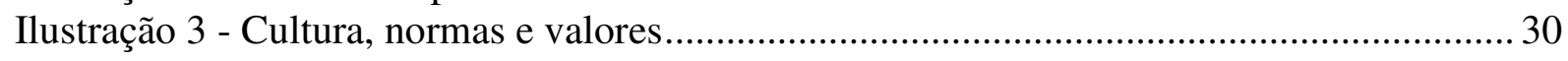

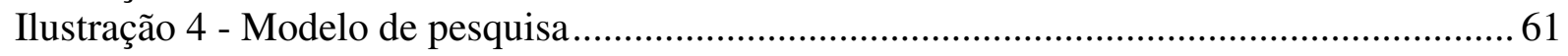

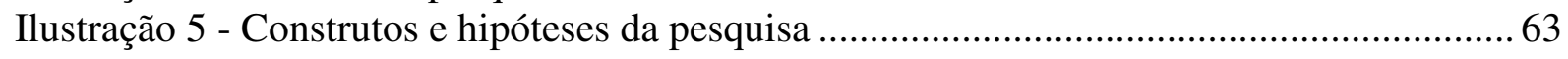

Ilustração 6 - Estratégia de pesquisa sequencial explanatória.................................................. 66

Ilustração 7 - Desenho da pesquisa: relação entre os objetivos específicos e a abordagem do

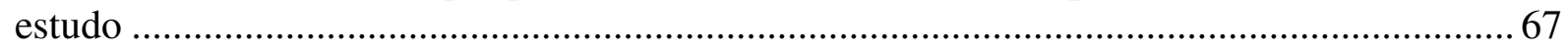

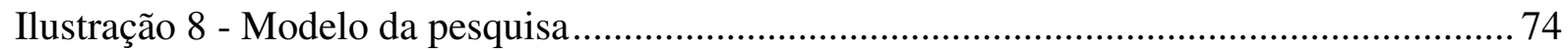

Ilustração 9 - Modelo proposto na modelagem de equações estruturais ................................. 85

Ilustração 10 - Desenho da pesquisa qualitativa ............................................................... 93

Ilustração 11 - Modelo proposto na modelagem de equações estruturais .............................. 130

Ilustração 12 - Modelo de mensuração final ( $9^{a}$ estimação) ……........................................ 134

Ilustração 13 - Bootstrapping do modelo estrutural final (valores t) ..................................... 140

Ilustração 14 - Modelo de mensuração - principais construtos ............................................ 140

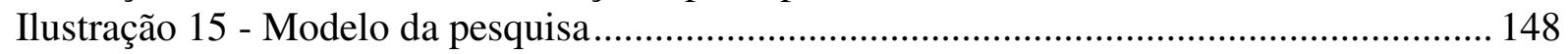




\section{1 - INTRODUÇÃO}

As empresas brasileiras, após a abertura de mercado, no final do século XX, foram estimuladas a buscar novas oportunidades de negócios no contexto internacional como forma de aumentar suas competitividades.

Em 2008, aproximadamente 25,32\% das receitas das vinte maiores transnacionais brasileiras foram geradas em operações com o exterior. No mesmo período, seus ativos em outros países somaram R \$ 199,52 bilhões, o equivalente a 27,66\% do total e, o número de funcionários no estrangeiro cresceu 40,92\% em relação ao ano anterior (FUNDAÇÃO DOM CABRAL, 2009).

Ainda conforme estudo realizado pela Fundação Dom Cabral (2009), observa-se que mesmo em momentos de crise mundial, como em meados de 2008, as empresas multinacionais brasileiras têm demonstrado um resultado satisfatório no âmbito mundial.

Cabe salientar que em 2009, contudo, a crise atingiu com maior intensidade as empresas brasileiras, que passaram a repensar suas estratégias no contexto internacional diante dos cenários instáveis; o que fez com que algumas empresas brasileiras conseguissem manter o crescimento anual positivo nos mercados internacionais (FUNDAÇÃO DOM CABRAL, 2010).

Como resultado dessa nova postura no âmbito mundial, em fevereiro de 2010, o Banco Central divulgou que os investimentos de multinacionais brasileiras no exterior somaram US\$ 4,2 bilhões líquidos, representando um valor recorde para o mês e superior aos investimentos estrangeiros diretos recebidos pelo país.

Corroborando aos resultados supracitados, estudo realizado pela SOBEET $^{1}$ (2010) relacionado a 52 empresas nacionais com presença no exterior evidenciou que $48,8 \%$ dessas companhias têm a intenção de aumentar a seus investimentos no exterior no biênio 20102011, sendo que no ano passado o percentual era de 38,8\% para o biênio 2009-2010. A pesquisa revelou ainda que, para $25,9 \%$ das empresas estudadas, a competitividade internacional da empresa é o principal motivo da sua atuação no estrangeiro. No entanto, outros motivos tais como demanda mundial $(19,5 \%)$, busca de economia de escala $(15,1 \%)$ e

\footnotetext{
${ }^{1}$ Sociedade Brasileira de Estudos de Empresas Transnacionais e da Globalização Econômica
} 
redução da dependência do mercado doméstico (13,7\%) também são relevantes. Outra evidência da expansão das empresas brasileiras no exterior é o índice de internacionalização (UNCTAD $^{2}$ ) que subiu de 14,9\% em 2006 para 16,7\% em 2007 e alcançou 17,4\% em 2008 (REVISTA VALOR ECONÔMICO, 2010).

$\mathrm{Na}$ literatura sobre negócios internacionais, as empresas dos países em desenvolvimento que investem no exterior - como é o caso das empresas brasileiras - são caracterizadas como entrantes tardios ou late movers. Conforme definem Fleury, A. e Fleury, M. T. (2007, p. 4), os entrantes tardios são:

[...] empresas maduras e integradas que cresceram em mercados protegidos da competição internacional; utilizam recursos naturais e mão-de-obra barata; não possuem competências tecnológicas; atrasadas em termos de capacitação gerencial; operam em ambientes extremamente turbulentos.

Tais entrantes tardios também são denominados de multinacionais de países emergentes, que passam por rápido crescimento econômico, industrialização e modernização. Ao mesmo tempo que esses mercados são atrativos para investimentos estrangeiros, começaram a gerar novos desafiantes globais, empresas que rapidamente se tornam os principais concorrentes dos mercados mundiais, impondo desafios competitivos às empresas das economias avançadas como Europa, Japão e América do Norte (CAVUSGIL et al , 2010).

Dessa forma, a busca pela compreensão do processo e atuação mundial das empresas brasileiras de internacionalização das empresas tem fomentado variadas discussões acadêmicas no âmbito nacional e internacional que, segundo Fleury, A. e Fleury, M. T. (2007), permeiam três abordagens principais de estudo: análise da corporação como todo e foco na matriz, ênfase nas subsidiárias e gestão de operações internacionais.

A corrente de estudos da visão baseada em recursos na área de negócios internacionais (BARNEY, 1991; HOLSAPPLE; JOSHI, 2003; BIRKINSHAW, 1999; RUGMAN; VERBEKE, 2001) tem demonstrado que as multinacionais apresentam um papel relevante no processo de criação de vantagens competitivas das empresas.

Dessa forma, as empresas são estudadas em termos de como os recursos que dispõem podem favorecer seu desempenho em um ambiente dinâmico e competitivo. A vantagem competitiva de uma organização é decorrente de como esta utiliza e combina, da melhor forma possível,

\footnotetext{
${ }^{2}$ Unctad - Conferência das Nações Unidas para o Comércio e Desenvolvimento
} 
os seus recursos financeiros, materiais, humanos e conhecimento (HOLSAPPLE; JOSHI, 2003).

As subsidiárias têm um papel crítico para o sucesso das multinacionais, seja em termos das suas habilidades para vender produtos internacionalmente ou em termos de adicionar valor agregado nas atividades de pesquisa e desenvolvimento ou de manufatura (BIRKINSHAW; HOOD, 1998). No entanto, segundo estes autores, apesar da grande importância das subsidiárias, estas só se tornaram objeto de estudo a partir da década de 80, quando surgiram indagações sobre o relacionamento entre matrizes e subsidiárias, seus papéis e estratégias diante da corporação, redes de relacionamento, impacto na economia local, recursos e capacidades.

Um dos pré-requisitos para que a subsidiária favoreça a vantagem competitiva das multinacionais é que aquela desenvolva conhecimentos, os quais possam ser transferidos a estas e usados por outras filiais espalhadas pelo mundo (SUMELIUS; SARALA, 2008). Segundo Nohria e Ghoshal (1997), a subsidiária que possui conhecimento é capaz de tomar decisões melhores e, com isso, contribuir mais para o desenvolvimento eficiente da corporação como um todo.

No âmbito mundial, as pesquisas sobre as subsidiárias têm ocorrido em três linhas principais: relacionamento matriz e subsidiária, papel da subsidiária e desenvolvimento da subsidiária, conforme exposto no quadro 1.

Quadro 1 - Principais linhas de pesquisas na gestão de subsidiárias

\begin{tabular}{|c|c|c|c|}
\hline Aspecto & $\begin{array}{c}\text { Relacionamento matriz } \\
\text { e subsidiária }\end{array}$ & Papel da subsidiária & $\begin{array}{c}\text { Desenvolvimento da } \\
\text { subsidiária }\end{array}$ \\
\hline Foco da pesquisa & $\begin{array}{c}\text { Aspectos do } \\
\text { relacionamento entre } \\
\text { matriz e subsidiária }\end{array}$ & $\begin{array}{c}\text { Fatores internos, } \\
\text { corporativos e ambientais } \\
\text { explicando diferentes } \\
\text { papéis da subsidiária }\end{array}$ & $\begin{array}{c}\text { Mudanças nos papéis e } \\
\text { atividades da subsidiária } \\
\text { constantemente }\end{array}$ \\
\hline $\begin{array}{c}\text { Suposições sobre a } \\
\text { natureza das } \\
\text { multinacionais }\end{array}$ & $\begin{array}{c}\text { Hierarquia: subsidiárias } \\
\text { são controladas pela } \\
\text { matriz }\end{array}$ & $\begin{array}{c}\text { Heterárquico e redes: subsidiárias têm diferentes } \\
\text { papéis e relacionamento com diversas unidades dentro } \\
\text { e fora da multinacional. }\end{array}$ \\
\hline Fundamentação teórica & $\begin{array}{c}\text { Teoria de custo de } \\
\text { transação e teoria } \\
\text { convergente }\end{array}$ & Teoria de redes sociais & $\begin{array}{c}\text { Teoria evolucionária e } \\
\text { teoria baseada em } \\
\text { recursos }\end{array}$ \\
\hline
\end{tabular}

Fonte: Adaptação de BIRKINSHAW e HOOD, 1998.

No entanto, a maioria desses estudos sobre subsidiárias debruçam-se nas pesquisas acerca de multinacionais de países desenvolvidos, justificando-se pelo fato destas existirem há mais tempo. 
Alguns estudos sobre subsidiárias de multinacionais brasileiras têm sido realizados (BORINI, 2008; OLIVEIRA JUNIOR, 2009) no âmbito do Projeto Temático GINEBRA - Gestão Empresarial para a Internacionalização das Empresas Brasileiras - financiado pela Fundação de Amparo à Pesquisa do Estado de São Paulo - FAPESP, no período entre 2006 e 2008, coordenado por professores da Universidade de São Paulo - USP.

Decorrentes desse projeto, informações importantes sobre a questão do desenvolvimento e do reconhecimento das competências das subsidiárias de multinacionais brasileiras foram levantadas (FLEURY, 2010), porém apenas sobre os aspectos predominantemente estruturais. No entanto, Borini (2008) ressalta que aspectos mais comportamentais, tais como a cultura nacional e a transferência de conhecimento entre a matriz e a subsidiária devem ser considerados.

Assim, diante do processo recente da internacionalização das empresas brasileiras, que ainda suscita estudos para melhor compreender a dinâmica e o estabelecimento dos entrantes tardios verde-amarelos em todos os continentes e, visto que os estudos sobre subsidiárias de multinacionais brasileiras ainda são incipientes, o intuito desta pesquisa foi explorar mais profundamente os aspectos da subsidiária diante da corporação como um todo e do mercado local em que se encontra inserida.

No âmbito das subsidiárias de multinacionais brasileiras buscou-se compreender a dinâmica do processo de transferência de conhecimento entre as unidades e analisar aspectos culturais locais e as influências da matriz. E essencialmente, entender como estas questões influenciam a própria iniciativa da subsidiária.

Cabe salientar que apesar de existirem várias definições para empresas atuantes em mercados internacionais, melhor explicado no decorrer do capítulo da revisão teórica, neste estudo optou-se pelo uso de multinacionais, independente do nível e estágio de internacionalização da empresa.

Desta maneira, uma contribuição importante esperada do estudo estava relacionada à iniciativa da subsidiária. Por ser uma temática nova, pretendeu-se identificar fatores relevantes que possibilitassem, de alguma forma, acréscimos ao contexto acadêmico e empresarial, visando indicar às multinacionais brasileiras estratégias e direções para aumentar a competitividade. Igualmente, a validação do modelo de análise para a iniciativa da subsidiária, privilegiando aspectos comportamentais como cultura e processo de transferência 
de conhecimento, permitindo que novos estudos sejam realizados no contexto nacional e mundial.

O objetivo geral do estudo foi analisar a influência da transferência de conhecimento e de fatores culturais na iniciativa das subsidiárias de multinacionais brasileiras. A busca pelo cumprimento do objetivo geral definiu-se quatro objetivos específicos:

1- Explorar o processo de transferência de conhecimento entre a subsidiária e a matriz: identificar quais são os mecanismos de transferência de conhecimento mais utilizados pelas multinacionais brasileiras, bem como as barreiras existentes neste processo, comparando-se as subsidiárias adquiridas com greenfield;

2 - Identificar características da cultura da subsidiária: compreender as características da cultura local da subsidiária e verificar se existem semelhanças e diferenças destas em relação ao Brasil ou mesmo se aspectos da cultura brasileira são percebidos nas unidades;

3- Analisar a influência da cultura e da transferência de conhecimento na iniciativa da subsidiaria: identificar se a transferência de conhecimento e a cultura influenciam direta e positivamente à iniciativa da subsidiária; bem como se existe relação direta e positiva entre a cultura e a transferência de conhecimento; e

4- Identificar se a cultura, a transferência de conhecimento e a iniciativa permitem a configuração de grupos homogêneos de subsidiárias: procurar agrupar as subsidiárias em grupos com características semelhantes, criando uma categorização das empresas em relação a iniciativa das mesmas.

Para tanto, este trabalho está estruturado em oito capítulos, incluindo esta introdução. No segundo capítulo, apresentam-se os principais conceitos e teorias pertinentes aos construtos deste estudo: iniciativa das subsidiárias, transferência de conhecimento e cultura. 
No capítulo três, a formulação das hipóteses do estudo, bem como a construção do modelo de pesquisa é apresentada. No seguinte, os procedimentos metodológicos são explicitados, destacando as particularidades de cada etapa da pesquisa.

O quinto e o sexto capítulos retratam as análises dos dados e os principais resultados da etapa quantitativa e qualitativa, respectivamente. Na etapa quantitativa, utiliza-se os dados uma amostra de 66 subsidiárias para análise, enquanto que na qualitativa, explora-se o modelo de pesquisa no âmbito da Weg S.A., multinacional brasileira.

Os principais alcances com a pesquisa são apresentados no sétimo capítulo por meio da discussão conjunta dos resultados quantitativos e qualitativos em relação a cada objetivo específico delineado.

Enfim, no último capítulo, das considerações finais, as principais contribuições do estudo são ressaltadas, assim como as limitações da pesquisa e sugestões para futuros trabalhos acadêmicos. 


\section{2 - REVISÃO TEÓRICA}

Neste capítulo, subdividido em três partes principais, elenca-se o quadro teórico no qual a pesquisa está inserida, tendo em vista o objetivo geral de analisar a influência da transferência de conhecimento e de fatores culturais na iniciativa das subsidiárias de multinacionais brasileiras.

Inicialmente são abordados alguns conceitos relacionados ao modelo de gestão das subsidiárias, destacando o papel e a estratégia destas diante da corporação multinacional. Posteriormente, explora-se o conceito de iniciativa da subsidiária, os tipos, processo e tipologia existente.

Na segunda parte, a cultura é o ponto de central da discussão. Os conceitos antropológicos e sociológicos são apresentados em um primeiro momento, seguidos pela abordagem da cultura nacional e cultura organizacional. Finaliza-se com a exploração de aspectos particulares da cultura brasileira e os seus impactos no estilo de gestão.

$\mathrm{Na}$ última parte deste capítulo discutem-se aspectos relacionados à transferência de conhecimento entre a subsidiária e a matriz em todos os sentidos, destacando os mecanismos e as barreiras existentes nestes processos, além da comparação destes entre as subsidiárias adquiridas e as greenfield.

\section{1 - Modelos de gestão das subsidiárias}

Segundo Birkinshaw et al. (1998) a subsidiária é considerada como qualquer unidade de operação controlada por uma multinacional fora do seu país de origem. Hill (2003) identifica a multinacional como sendo qualquer empresa engajada no cenário internacional ou com investimento internacionais. Bartlett e Ghoshal (1999) consideram a multinacional como sendo a empresa que possui investimentos diretos em países estrangeiros e administra suas operações internacionais. Rugman e Verbeke (2001) são mais específicos ao definir multinacional como a empresa que vende ou produz no exterior.

Para compreender os papéis e as estratégias da subsidiária, torna-se imprescindível identificar a estratégia de gestão da empresa corporativa. Assim, esta seção está subdividida em três 
partes que estudam as gestões das multinacionais e das subsidiárias e, por fim, a iniciativa destas.

\subsection{1 - Estratégias das multinacionais}

Em relação aos modelos de organizações multinacionais, destaca-se na literatura a proposta de Bartlett e Ghosal (1989) que propõem uma tipologia baseada na combinação de duas dimensões: responsividade local e integração global. Conforme apresentado no Quadro 2, dependendo do grau destas dimensões, a organização pode ser classificada em: multinacional, internacional, transnacional e global. Os autores defendem a ideia de que a internacionalização é um processo que pode ocorrer de formas diferentes, dependendo do tipo de organização, produto e estratégia.

Quadro 2- Características Organizacionais das Corporações Multinacionais

\begin{tabular}{|c|c|c|c|c|}
\hline & Multinacional & Global & Internacional & Transnacional \\
\hline $\begin{array}{l}\text { Configuração de } \\
\text { ativos e recursos }\end{array}$ & $\begin{array}{l}\text { Descentralizado e } \\
\text { auto-suficiente } \\
\text { nacionalmente }\end{array}$ & $\begin{array}{l}\text { Centralizado e } \\
\text { escala global }\end{array}$ & $\begin{array}{c}\text { Fontes de } \\
\text { competências } \\
\text { essenciais } \\
\text { concentradas, outras } \\
\text { descentralizadas }\end{array}$ & $\begin{array}{c}\text { Disperso, } \\
\text { interdependente e } \\
\text { especializado }\end{array}$ \\
\hline $\begin{array}{l}\text { Papel das } \\
\text { subsidiárias no } \\
\text { exterior }\end{array}$ & $\begin{array}{c}\text { Sentir e explorar as } \\
\text { oportunidades } \\
\text { locais }\end{array}$ & $\begin{array}{c}\text { Implementar as } \\
\text { estratégias da } \\
\text { matriz }\end{array}$ & $\begin{array}{c}\text { Adaptação e } \\
\text { alavancar as } \\
\text { competências da } \\
\text { corporação }\end{array}$ & $\begin{array}{c}\text { Contribuições } \\
\text { diferenciadas pelas } \\
\text { unidades nacionais } \\
\text { para integrar } \\
\text { operações } \\
\text { mundiais }\end{array}$ \\
\hline $\begin{array}{l}\text { Desenvolvimento } \\
\text { e difusão do } \\
\text { conhecimento }\end{array}$ & $\begin{array}{l}\text { Desenvolvimento } \\
\text { do conhecimento é } \\
\text { mantido em cada } \\
\text { unidade }\end{array}$ & $\begin{array}{l}\text { Desenvolvimento } \\
\text { do conhecimento é } \\
\text { mantido no centro }\end{array}$ & $\begin{array}{l}\text { Desenvolvimento } \\
\text { do conhecimento no } \\
\text { centro e transferido } \\
\text { para as unidades }\end{array}$ & $\begin{array}{l}\text { Desenvolvimento } \\
\text { do conhecimento } \\
\text { em conjunto e } \\
\text { compartilhado } \\
\text { entre as unidades }\end{array}$ \\
\hline
\end{tabular}

Fonte: BARTLETT; GHOSHAL, 1999, p. 75

As empresas multinacionais apresentam alta responsividade local e baixa integração com as outras unidades, ou seja, buscam explorar o máximo possível das oportunidades locais, com total independência da matriz; enquanto as empresas globais seguem as diretrizes estratégicas da matriz e têm o foco principal na eficiência das operações mundiais (BARTLETT; GHOSHAL, 1999). 
A empresa internacional caracteriza-se pela mescla entre os dois tipos anteriores. A matriz influencia e controla as subsidiárias, mas não tanto como as empresas globais e, permite que as unidades atendam às necessidades locais, com produtos e serviços, com menor responsividade local do que as multinacionais (BARTLETT; GHOSHAL, 1999).

O pressuposto do modelo transnacional é a rede diferenciada, no qual a relação entre a subsidiária e a matriz e as outras unidades ocorre de forma variada. A integração da rede por meio de mecanismos de controle e coordenação, bem como os frequentes fluxos de comunicação entre matriz e subsidiária são frequentes (BARTLETT; GHOSHAL, 1999).

Outra classificação sobre estratégias nos negócios internacionais é proposta por Hill (2005): estratégia de localização, estratégia internacional, estratégia de padronização global e estratégia transnacional. Firmas que enfatizam a estratégia de localização tendem a criar valor com ênfase na rapidez de resposta local e denominam-se responsividade local (HILL, 2005; VANCE; PAIK, 2006). Firmas internacionais caracterizam-se pela transferência de produtos e competências entre países; as globais, por reconhecer a curva de experiência e as economias de localização e as transnacionais, por fazer tudo simultaneamente.

Vance e Paik (2006) apresentam outra classificação, também separadas em quatro categorias: estratégia global, estratégia multidoméstica, estratégia transnacional e estratégia regional. A estratégia global ocorre quando a posição competitiva de uma empresa em um país é influenciada por sua posição em outros países. Em geral, a firma integra suas atividades ao redor do mundo para captar e se beneficiar de conexões e sinergias entre países, ganhando vantagem competitiva. É uma estratégia com foco em eficiência e redução de custos.

A estratégia multidoméstica enfatiza responsividade local, na qual os gerentes têm autonomia substancial para adaptar as estratégias da subsidiária às situações locais. Sobre a estratégia transnacional, os autores anteriormente mencionados ressaltam que há uma busca pelo equilíbrio entre os desafios da redução de custo pela integração global e a responsividade local. Neste caso, o foco está na aprendizagem global, cujo conhecimento deve fluir tanto da matriz para as subsidiárias quanto das subsidiárias para a matriz e também entre as subsidiárias. Este tipo de estratégia apresenta mais autonomia do que a estratégia global, porém menos que a estratégia multidoméstica. Como a estratégia transnacional, que poderia ser considerada ideal, não é tão simples, uma alternativa seria adotar a chamada estratégia 
regional, dividindo o globo em regiões econômicas com o propósito de equilibrar as responsividades locais com a eficiência global por região (VANCE; PAIK, 2006).

Pode-se observar certa similaridade entre as definições utilizadas por Bartlett e Ghosal (1999), Hill (2005) e Vance e Paik (2006), apesar das diferentes nomenclaturas em alguns casos (Quadro 3).

Quadro 3 - Semelhanças de conceitos de estratégias em negócios internacionais
\begin{tabular}{|c|c|c|}
\hline Bartlett e Ghosal (1999) & Vance e Paik (2006) & Hill (2005) \\
\hline Multinacional & Multidoméstica & Internacizacional \\
\hline Internacional & Global & Padronização global / Transnacional \\
\hline Transnacional & Transnacional & \\
\hline Global & Regional & \\
\hline
\end{tabular}

Fonte: Elaborado a partir de BARTLETT e GHOSAL (1999), VANCE e PAIK (2006); HILL (2005)

No entanto, observa-se que os autores buscam constantemente a definição de um modelo multidimensional integrador, garantindo a eficiência global e a resposta local, além da inovação e disseminação do conhecimento em termos globais.

Outro teórico da área que tem destacado aspectos importantes relacionados ao ambiente internacional é Ghemawat (2008), o qual enfatiza que ao definirem estratégias para criação global de valor, as empresas internacionais devem considerar as questões administrativas (política e educacional) e econômicas, bem como o tamanho do país sede da subsidiária.

Desta maneira, o autor sugere a análise das dimensões CAGE (cultural, administrativa, geográfica e econômica) de distância, ou seja, identificar as diferenças e semelhanças entre o país da matriz e o país da subsidiária.

No âmbito das multinacionais brasileiras, Borini (2010) identificou aspectos econômicos e políticos que influenciam no desempenho das subsidiárias. Segundo o autor, as unidades localizadas em ambiente competitivos, apresentando alta interação com as redes locais e um sistema político favorável, estão mais propensas ao investimento no desenvolvimento de competências e resultados vantajosos para a corporação como um todo.

Em contraponto, as subsidiárias localizadas em contextos políticos e mercados não estruturados, “...teriam menor propensão para constituir elos da cadeia produtiva global e deveriam ter um enfoque estratégico de exploração de mercado para obtenção de um retorno superior..." (BORINI, 2010, p. 97). 


\subsection{2 - Estratégias das subsidiárias}

Na visão baseada em recursos, especificamente para Barney (1991), uma subsidiária é concebida como um conjunto de recursos heterogêneos, os quais podem oferecer potencial contribuição para a vantagem específica da firma. Para tanto, há três critérios que devem ser identificados e posteriormente, potencializados pela subsidiária: valor dos recursos, reconhecimento destes pela gestão corporativa e a efetiva transferência destes recursos.

Assim como na matriz, a maioria dos estudos sobre a subsidiária analisa o papel ou a estratégia da unidade diante da corporação. A distinção entre os termos estratégia e papel da subsidiária é mais que semântica. Papel sugere a um processo determinístico no qual a subsidiária é imposta. A estratégia sugere um alto grau de liberdade por parte da gestão da subsidiária para definir os seus próprios destinos (PRAHALAD; DOZ, 1981).

Dentre as tipologias de estratégia da subsidiária, diante do presente estudo, destacam-se três propostas mais interessantes, conforme Quadro 4.

\begin{tabular}{|c|c|c|c|c|}
\hline Autores & \\
\hline $\begin{array}{c}\text { Birkinshaw e } \\
\text { Morrisson (1995) }\end{array}$ & $\begin{array}{c}\text { Papel da subsidiária } \\
\text { diante da estratégia } \\
\text { da matriz }\end{array}$ & $\begin{array}{l}\text { Implementador } \\
\text { local }\end{array}$ & $\begin{array}{l}\text { Contribuidor } \\
\text { especializado }\end{array}$ & Mandato mundial \\
\hline $\begin{array}{c}\text { Bartlett e Ghoshal } \\
\text { (1992) }\end{array}$ & $\begin{array}{c}\text { Importância } \\
\text { estratégica e } \\
\text { capacidade do local }\end{array}$ & Implementador & Contribuidor & Líder estratégico \\
\hline $\begin{array}{c}\text { Gupta e } \\
\text { Govindarajan } \\
(1991)\end{array}$ & $\begin{array}{l}\text { Dinâmica de } \\
\text { transferência de } \\
\text { conhecimento }\end{array}$ & $\begin{array}{l}\text { Inovador local e } \\
\text { implementador }\end{array}$ & Inovador global & Integrador \\
\hline
\end{tabular}

Fonte: Adaptado de BIRKINSHAW; MORRISSON, 1995

Gupta e Govindarajan (1991), considerando a dinâmica de transferência de conhecimento, propuseram um modelo de análise da subsidiária ponderando duas dimensões espaciais: a extensão em que a subsidiária busca absorver (internalizar) o conhecimento oriundo do resto da multinacional e, a extensão em que a subsidiária busca disponibilizar o seu conhecimento para as outras unidades da corporação.

Assim, considerando os fluxos de conhecimentos, a subsidiária pode apresentar quatro papéis gerais: inovador global, integrador, implementador $\mathrm{e}$ inovador local (GUPTA; GOVINDARAJAN, 1991). 
No papel de inovador global, a subsidiária serve como fonte de conhecimento para as outras unidades. O papel de integrador é similar ao de inovador global porque também implica na responsabilidade de criar conhecimento, o qual pode ser utilizado pelas demais unidades. No entanto, diferente do inovador global, este tipo de subsidiária não é auto-suficiente no sentido de gerar todo o conhecimento necessário para a sua eficiência e eficácia, precisando dos conhecimentos criados nas outras unidades (GUPTA; GOVINDARAJAN, 1991).

No papel de implementador, a subsidiária cria pouco conhecimento local, mas absorve muito conhecimento das outras unidades da corporação. E o papel de inovador local representa a subsidiária que apresenta completa responsabilidade local para criar relevantes conhecimentos nas suas áreas funcionais, visando melhor resultado organizacional (GUPTA; GOVINDARAJAN, 1991).

Birkinshaw e Morrisson (1995) desenvolveram uma tipologia em relação ao papel da subsidiária, identificando três perspectivas diferentes: o implementador local, o contribuidor especializado e o mandato mundial.

No caso do implementador local, a subsidiária apresenta escopo geográfico limitado, próprio de um único país. Como apresentado no Quadro 4, Gupta e Govindarajan (1991) denominam de inovador local e implementador. O papel principal da subsidiária é a adaptação de produtos globais à necessidade do mercado local. É tipicamente encontrada (não exclusivamente) na estratégia multidoméstica.

A subsidiária que tem considerável expertise em certas funções ou atividades, sendo as atividades rigidamente coordenadas com as atividades das outras subsidiárias é denominada de contribuidora especializada. Para Gupta e Govindarajan (1991), esta subsidiária é conhecida como inovadora global e na tipologia de Bartlett e Ghoshal (1992), denomina-se contribuidora.

O mandato mundial caracteriza-se pela subsidiária que apresenta responsabilidade regional ou global por uma linha de produto ou negócio. O seu papel é tão estratégico para a corporação como um todo que Bartlett e Ghoshal (1992) denominam de líder estratégico, enquanto que para Gupta e Govindarajan (1991) é reconhecida como integradora.

No entanto, o modelo proposto por Bartlett e Ghoshal (1992) considera a importância estratégica do ambiente local. A importância estratégica de uma unidade de um país 
específico é fortemente influenciada pela importância de seu ambiente nacional para a estratégia global da empresa. Desta maneira, a subsidiária pode apresentar três classificações principais: líder estratégico, colaborador e implementador.

Assim, caracteriza a subsidiária com alta competência em um mercado importante estrategicamente para a corporação multinacional, como uma subsidiária "líder estratégica". Neste papel, a subsidiária serve como um parceiro da matriz na identificação de ameaças e oportunidades, bem como na elaboração e implementação de estratégias.

No papel de colaborador, a subsidiária apresenta alta capacidade, mas está localizada em um ambiente não tão atrativo estrategicamente para a corporação; enquanto que no caso do implementador, a capacidade da subsidiária é suficiente para atender às necessidades do mercado local.

\subsection{3 - Iniciativa das subsidiárias}

A gestão das multinacionais é constantemente foco de discussões sobre vários aspectos diferentes. Uma das questões principais é a dicotomia entre o controle central pela matriz versus a iniciativa das subsidiárias.

De um lado, o controle central pela matriz é positivo quando se analisa a facilidade de coordenação corporativa, a consistência na tomada de decisões e o poder de decisão dos gestores corporativos para os processos de mudanças necessários. Por outro lado, a descentralização reduz a responsabilidade dos gestores corporativos, mas melhora a qualidade das decisões, motiva os colaboradores das subsidiárias e permite maior velocidade, flexibilidade e inovação (PENG, 2008), possibilitando a iniciativa da subsidiária.

Segundo Birkinshaw et al. (1998, p.225), o grande diferencial de uma subsidiária é a sua iniciativa de desenvolvimento do negócio (ou simplesmente, iniciativa), definida como a “proativa e deliberada busca por novas oportunidades de negócios pela subsidiária a fim de expandir seu escopo de responsabilidade, estando alinhada com os objetivos estratégicos da corporação". 
A iniciativa da subsidiária é muito importante, por duas razões: é o principal modo que a multinacional pode identificar oportunidades ao redor do mundo, além de proporcionar a melhoria da sua eficiência operacional por meio da competição interna das unidades (BIRKINSHAW; FRY, 1998).

No entanto, a iniciativa da subsidiária pode refletir diretamente a postura da matriz. Muitas multinacionais estudadas por esses autores desencorajam esforços empreendedores por parte das suas subsidiárias, enquanto outras concordam com o conceito em princípio, mas dificultam o seu desenvolvimento na prática.

Conforme demonstrado na Ilustração 1, Birkinshaw (1999) desenvolveu um modelo de análise da iniciativa da subsidiária em relação ao contexto organizacional, ou seja, o conjunto de mecanismos administrativos e sociais que configuram os comportamentos dos atores na organização, sobre os quais a alta gestão tem controle. $\mathrm{O}$ autor propôs uma análise em dois níveis: contexto corporativo e contexto da subsidiária, cujas dimensões foram classificadas em estruturais ou comportamentais. Além disso, existe o contexto ambiental local da subsidiária que lhe influencia diretamente.

Bower (1970 apud Birkinshaw, 1999) definiu contexto estrutural como o conjunto de forças organizacionais que influenciam o processo de definição e impulsão dos negócios, tais como: organização formal, sistema de informação e controle usado para mensurar os resultados organizacionais, além dos sistemas para medir e recompensar o desempenho gerencial. Birkinshaw (1999) evidencia que o conceito de contexto comportamental foi inicialmente utilizado por Bartlett e Ghoshal em 1995, caracterizando-o como desdobramento de uma ética cuidadosamente fomentada e enraizada no ambiente de trabalho das empresas, que desencadeia os comportamentos em nível individual, do espírito empresarial, colaboração e aprendizagem. O contexto comportamental, segundo Barnard (1938 apud Birkinshaw, 1999) existe como um conjunto de valores e crenças orientadoras, sendo o seu desenvolvimento responsabilidade da alta direção.

No entanto, Birkinshaw (1999) ressalta que os efeitos do contexto estrutural sobre a iniciativa têm sido mais estudados quando comparados ao contexto comportamental, embora existam discussões sobre várias facetas da cultura organizacional como direcionadora do empreendedorismo corporativo, não sendo exploradas aqui por não fazerem parte do escopo do trabalho. 


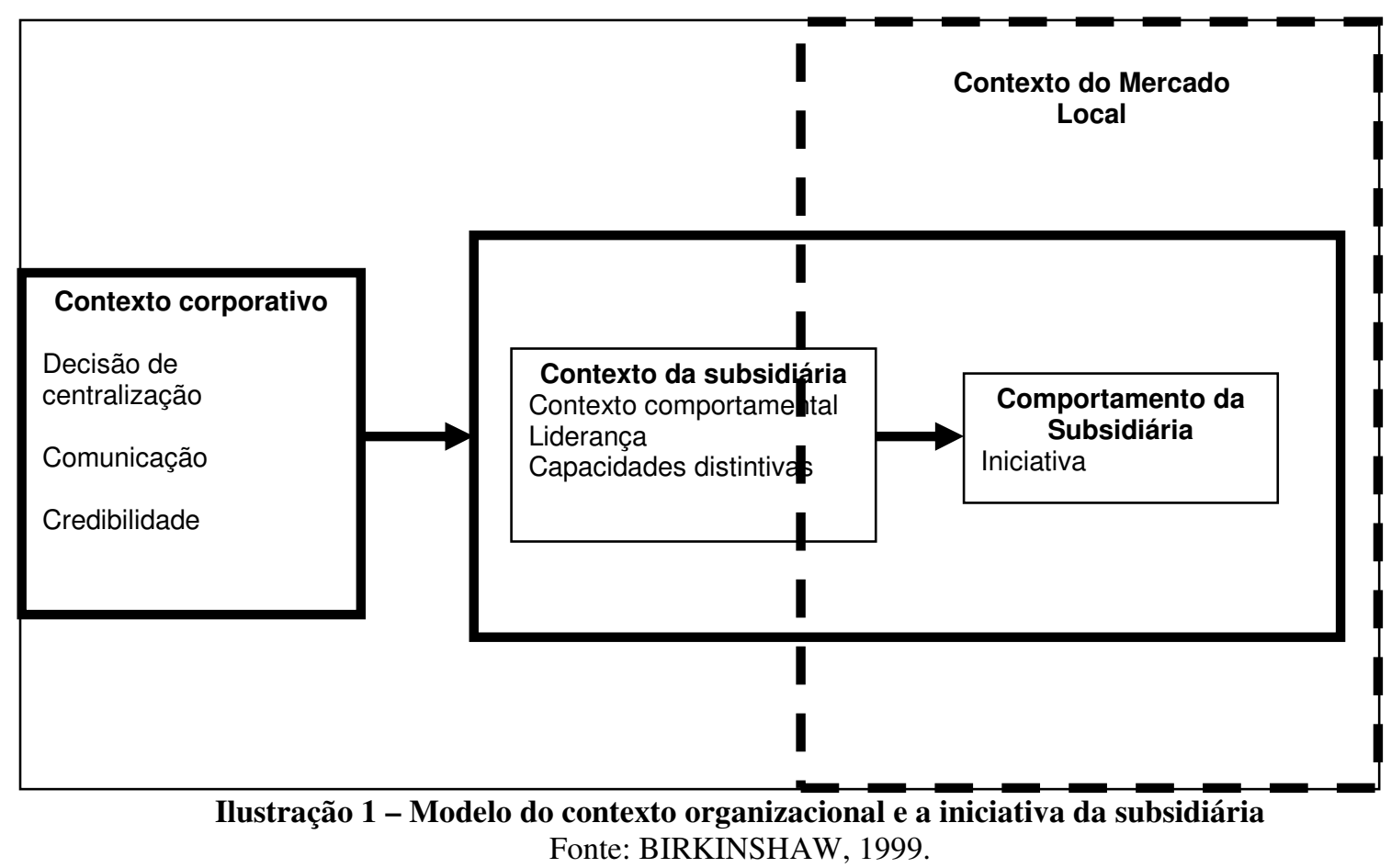

No modelo proposto, em relação ao contexto corporativo, o autor identificou três dimensões relevantes, sendo uma estrutural e duas comportamentais. A centralização das decisões é a dimensão estrutural, e representa o quanto os gestores corporativos têm responsabilidade sobre decisões em relação às atividades realizadas pela subsidiária. O efeito previsto da centralização das decisões das subsidiárias em relação a sua iniciativa é negativo, visto que muitos estudos apontam uma ligação entre a descentralização da tomada de decisão e atividades empreendedoras (BIRKINSHAW, 1999).

As duas dimensões comportamentais são: credibilidade da subsidiária e comunicação entre a matriz e a subsidiária. A credibilidade indica em que medida os gestores da matriz estão conscientes e confiantes na capacidade da subsidiária, enquanto a comunicação representa as interações pessoais ou por meio de tecnologia entre essas, permitindo a socialização organizacional e a integração dos processos normativos. Isto se processa por meio das crenças individuais, valores e normas. $\mathrm{O}$ autor salienta que o efeito esperado destas duas dimensões comportamentais em relação à iniciativa é positivo, ou seja, um o alto nível de comunicação entre a matriz e a subsidiária e um alto nível de credibilidade da subsidiária em relação a matriz promovem a iniciativa (BIRKINSHAW, 1999). 
Em relação ao contexto da subsidiária, Birkinshaw (1999) identifica três dimensões: contexto comportamental, a liderança e a capacidade distintiva. Considera o contexto comportamental como sendo o local de trabalho profundamente enraizado na ética empresarial, valorizado pelo empreendedorismo, colaboração e aprendizagem; enquanto a capacidade distintiva entende-se pela subsidiaria que adiciona valor às suas capacidades, tornando-a superior em relação às outras unidades. $\mathrm{O}$ autor acredita que neste contexto emergirá a iniciativa.

Um terceiro aspecto destacado no modelo é o impacto do contexto ambiental local na iniciativa, representado pelo conjunto de clientes, fornecedores, concorrentes e instituições que a unidade interage. Visto que estudos (ANDERSSON et al, 2002; RUGMAN; VERBEKE, 2001; BIRKINSHAW, 1999; HOLSAPPLE; JOSHI, 2003, BARTLETT; GHOSAL, 1999) sobre multinacionais expõem que as subsidiárias estrangeiras devam identificar ideias e oportunidades no mercado local para que possam ser usados pela corporação como um todo; conforme Birkinshaw (1999), um alto grau de dinamismo no mercado local promove a iniciativa da subsidiária.

Desta maneira, a iniciativa da subsidiária ocorre em ambos os contextos: corporativo e subsidiária; sendo que poderá ser promovida ou suprimida conforme a natureza do contexto, do nível da subsidiária e do nível corporativo. Cabe salientar que tal relação, é de fato, mediada pela gestão da subsidiária por meio do seu contexto.

Segundo pesquisa com 229 subsidiárias em três países (Canadá, Suécia e Escócia), o maior obstáculo para o desenvolvimento da iniciativa na subsidiária é a ausência de credibilidade, seguida pela decisão de centralização e pela falha na comunicação ente ela e sua matriz. $\mathrm{O}$ mesmo estudo evidenciou que as relações no mercado local podem ser fonte de estímulo para a iniciativa da subsidiária (BIRKINSHAW, 1999).

No entanto, não houve evidências de que a liderança e o contexto comportamental fossem promotores da iniciativa. Segundo Birkinshaw (1999) foi uma surpresa encontrar esse resultado porque a teoria sugere que o contexto da subsidiária deve ter um impacto forte na iniciativa; indicando que talvez as medidas do instrumento de coleta de dados tenham sido mal dimensionadas.

Esses estudos permitiram duas conclusões principais (BIRKINSHAW, 1999): tanto o contexto comportamental da subsidiária quanto o relacionamento informal da matriz com a 
subsidiária impactam na iniciativa, sendo que o ambiente da subsidiária afeta mais rapidamente e diretamente do que o contexto corporativo.

Pode-se perceber a iniciativa da subsidiária observando-se as ações internas e a postura comportamental dos seus gestores, pois quando estes começam a assumir responsabilidade pelo destino das operações da unidade é sinal de iniciativa. Logo, também, sugere-se que a subsidiária tenha maior controle e papel central na implementação de estratégias corporativas (BIRKINSHAW; FRY, 1998). Desta maneira, a iniciativa pode ocorrer independente do incentivo por parte da matriz.

Basicamente existem três tipos de iniciativas: globais, externas e internas, sendo que as globais e as externas estão muito próximas (BIRKINSHAW, 1997), que posteriormente Birkinshaw e Fry (1998) adotaram somente duas diferentes formas de iniciativa da subsidiária: foco externo e foco interno, ou seja, processo externo de iniciativa e processo interno de iniciativa.

O processo externo de iniciativa acontece no momento da identificação de novas oportunidades de negócios por meio da interação com os clientes, fornecedores e entidades governamentais no contexto local da subsidiária; enquanto que o processo interno de iniciativa envolve a identificação de novas oportunidades de negócios existentes dentro dos limites da corporação.

Em vários aspectos, as duas formas de iniciativa são muito diferentes, pois envolvem táticas distintas diante das diferentes formas de resistência e apresentam um significante impacto na gestão das multinacionais como um todo. Para as iniciativas externas é fundamental ter um alto grau de autonomia. Para as iniciativas internas é necessária uma integração forte no sistema corporativo, além de que a subsidiária deveria ter ou estar preparada para trabalhar fortemente visando uma reputação e operação confiável.

A questão das redes parece fundamental para o sucesso das iniciativas das subsidiárias. Para Andersson et al (2002), cada uma mantém padrões únicos de ligações com as redes e, consequentemente, é diferentemente exposta a novos conhecimentos, ideias e oportunidades. O recurso de redes de uma subsidiária pode influenciar a habilidade competitiva da multinacional de duas maneiras: primeiro, a inclusão da subsidiária na sua rede local impacta na sua capacidade competitiva no mercado local; segundo, se a subsidiária transfere esta 
capacidade para as outras e para a matriz, a competência da multinacional como um todo tem ganhos.

Assim, a iniciativa é vista como um caminho discreto e proativo para organizar, utilizar e expandir os seus recursos. Inicia-se com a identificação de um novo produto ou oportunidades de mercado pela subsidiária e, finaliza-se com o compromisso, pela corporação como um todo, de prover recursos para tais oportunidades (BIRKINSHAW, 1999).

Birkinshaw e Fry (1998) destacam que a questão do empreendedorismo está presente nas discussões sobre a iniciativa da subsidiária. Visto que o empreendedorismo corporativo envolve o surgimento de diferentes práticas ou uma nova maneira da corporação usar ou expandir seus recursos e a iniciativa é essencialmente um processo empreendedor, mas não necessariamente para a subsidiária ter iniciativa, precisa apresentar uma postura empreendedora. A orientação empreendedora é uma diretriz corporativa com o intuito de gerar um ambiente propício para oportunidades (BORINI, 2008).

Como mencionado anteriormente, estudiosos têm observado que a subsidiária apresenta papéis diferenciados, a depender de fatores, tais como da sua capacidade interna, do ambiente local e das suas relações com outras corporações. Borini (2008) identificou a iniciativa e a forma de interação nas redes externas conforme a estratégia da corporação (Quadro 5).

Quadro 5 - Iniciativa, redes e estratégias das multinacionais

\begin{tabular}{|c|c|c|}
\hline & Iniciativa & Redes externas \\
\hline Multidoméstica & $\begin{array}{l}\text { Importante apenas para a subsidiária e não para a } \\
\text { estratégia corporativa da matriz }\end{array}$ & $\begin{array}{l}\text { Importância exclusiva para a } \\
\text { subsidiária }\end{array}$ \\
\hline Global & $\begin{array}{c}\text { Interessante para incrementar processos produtivos } \\
\text { na subsidiária decorrente de diretrizes da matriz }\end{array}$ & Suporte para ações globais \\
\hline Transacional & $\begin{array}{l}\text { Estimulado somente em algumas subsidiárias } \\
\text { reconhecidas pela importância estratégica }\end{array}$ & $\begin{array}{l}\text { Importante para a criação de } \\
\text { iniciativas }\end{array}$ \\
\hline Metanacional & $\begin{array}{c}\text { Essencial para a estratégia de desenvolvimento de } \\
\text { novas competências, com importância estratégica } \\
\text { para a corporação }\end{array}$ & $\begin{array}{l}\text { Fundamental para a criação de } \\
\text { iniciativas e desenvolvimento de } \\
\text { novas competências }\end{array}$ \\
\hline
\end{tabular}

Birkinshaw (1995) propôs quatro ações principais para que a subsidiária possa desenvolver sua iniciativa. A primeira delas diz respeito aos recursos complementares, ou seja, a existência de recursos físicos como equipamentos, unidades fabris poderia ser aplicado em iniciativas buscando reduzir os custos incrementais. Esta ação também poderia contribuir para o processo contínuo de desenvolvimento da subsidiária. 
A utilização das competências essenciais da subsidiária na identificação de oportunidades de mercado é a segunda ação proposta e, desta maneira, por meio da otimização das suas competências, a subsidiária pode apresentar vantagem e exclusividade na busca por novas oportunidades, resultando em um processo maior de iniciativa (BIRKINSHAW, 1995).

O crescimento da reputação da subsidiária é importante fonte de iniciativas e está presente na terceira proposta do autor, visto que o sucesso das primeiras iniciativas aumenta a reputação da subsidiária com os gestores da multinacional, principalmente na matriz; melhorando assim as chances de futuras iniciativas serem aceitas (BIRKINSHAW, 1995).

A última ação, não menos importante, é o aprendizado com o processo de iniciativa. Os gestores da subsidiária ganham prestígio no contexto organizacional por meio dos seus acertos e erros. Logo, aprender por meio da busca de oportunidades é certamente um bom caminho para maximizar as chances de sucesso (BIRKINSHAW, 1999).

A partir das suas pesquisas, Birkinshaw (1995) propôs uma tipologia para a iniciativa das subsidiárias, relacionando a abrangência (contexto) de oportunidade de mercado utilizado pela unidade e o envolvimento da matriz no processo, apresentado na Ilustração 2.

Acredita-se que a subsidiária apresente um papel empreendedor, no qual a gerência possa distinguir e analisar ações para, no mínimo, manter o negócio. Assim, o papel empreendedor da subsidiária pode ser aplicado em três mercados: local, global e interno.

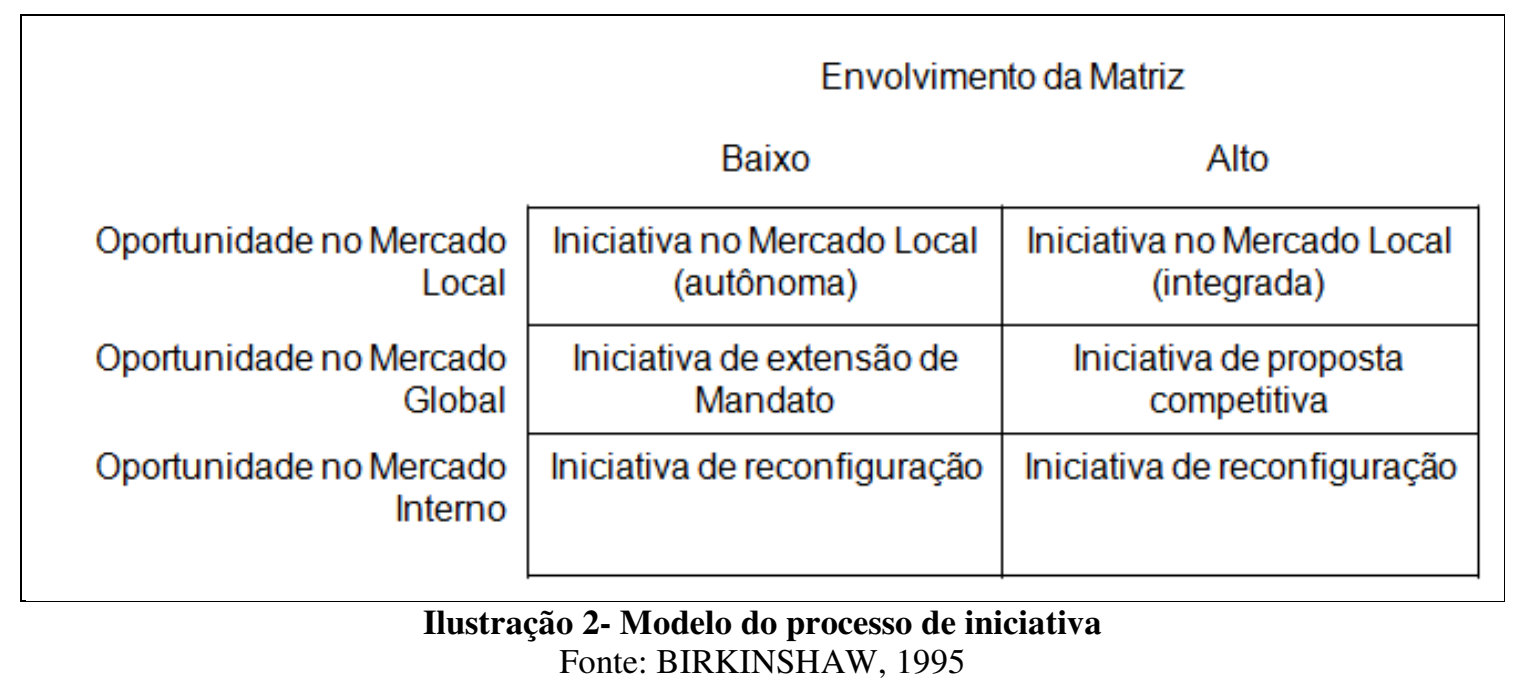

Assim, como o mercado de atuação, o nível do envolvimento da matriz é importante para compreender os tipos diferentes de iniciativa da subsidiária: iniciativa de reconfiguração, 
iniciativa no mercado local, iniciativa de proposta competitiva e a iniciativa da extensão do mandato. O Quadro 6 apresenta as principais características de cada iniciativa e os respectivos fatores chaves para o sucesso.

Quadro 6 - Características das iniciativas das subsidiárias

\begin{tabular}{|c|c|c|}
\hline Iniciativa & Característica & Fatores chaves para o sucesso \\
\hline Reconfiguração & $\begin{array}{l}\text { Subsidiária que promove a redistribuição dos } \\
\text { recursos existentes da empresa ou recursos } \\
\text { que são utilizados com mais eficácia }\end{array}$ & $\begin{array}{l}\text { - } \text { Timing } \\
\text { - Defesa dos esforços individuais } \\
\text { - Credibilidade e bom relacionamento } \\
\text { - } \quad \text { Prom a matriz } \\
\text { - Proposta convincente } \\
\end{array}$ \\
\hline Mercado local & $\begin{array}{l}\text { Subsidiária que procura desenvolver um } \\
\text { novo produto, mercado ou processo por meio } \\
\text { as oportunidades de negócios que são } \\
\text { primeiramente identificadas no contexto local } \\
\text { da subsidiária }\end{array}$ & $\begin{array}{l}\text { - Alto nível de autonomia e presença } \\
\text { local } \\
\text { - } \text { Ajuste com os objetivos estratégicos da } \\
\text { multinacional } \\
\text { - Criatividade e espírito empreendedor } \\
\text { na subsidiária }\end{array}$ \\
\hline $\begin{array}{c}\text { Proposta } \\
\text { competitiva }\end{array}$ & $\begin{array}{l}\text { Subsidiária que procura atrair investimento } \\
\text { global ou foco em atividades de valor } \\
\text { agregado internacionalmente com suporte (no } \\
\text { princípio) da multinacional/matriz }\end{array}$ & $\begin{array}{l}\text { - Garantia de Proposta competitiva } \\
\text { - Credibilidade da subsidiária } \\
\text { - Esforços de venda e de defesa }\end{array}$ \\
\hline $\begin{array}{l}\text { Extensão de } \\
\text { mandato }\end{array}$ & $\begin{array}{l}\text { Subsidiária que procura construir um } \\
\text { mandato em vigor ou capacidade } \\
\text { comprovada para atender a uma demanda } \\
\text { internacional do produto ou oportunidade de } \\
\text { mercado }\end{array}$ & $\begin{array}{l}\text { - Alto nível de autonomia } \\
\text { - Planos de negócios sólidos } \\
\text { - Adequação estratégica com a matriz }\end{array}$ \\
\hline
\end{tabular}

Fonte: Adaptado de BIRKINSHAW, 1995

Desta maneira, a iniciativa da subsidiária deve ser percebida como um dos caminhos possíveis para o crescimento e desenvolvimento das multinacionais.

\section{2 - Cultura}

Conforme mencionado anteriormente, a temática subsidiária tem sido de grande interesse pelos acadêmicos, a questão da iniciativa ainda é recente e incipiente. Desta maneira, apesar de alguns estudos tratarem da questão cultural no âmbito das subsidiárias, não há literatura específica sobre a questão da iniciativa à cultura, apenas desta ao empreendedorismo.

Assim, nesta seção as principais abordagens sobre cultura e os principais conceitos sobre cultura nacional e organizacional são explorados. Como este estudo versa sobre as multinacionais brasileiras, torna-se relevante apresentar as principais características culturais do país, bem como a influência destas no ambiente organizacional. 
No âmbito dos estudos organizacionais, o tema cultura tornou-se relevante na década de setenta do século passado e as diversas definições existentes estão sustentadas em teorias e definições de ciências humanas, principalmente na antropologia e na sociologia.

Sobre a influência da antropologia, Ouchi e Wilkins (1985) identificaram duas abordagens. $\mathrm{Na}$ primeira, consideram o grupo ou sociedade como um todo e observam como as suas práticas, crenças e outros elementos culturais funcionam para manter a estrutura social. A segunda abordagem baseia-se na semiótica e na antropologia cognitiva. A semiótica, reconhecida pelo trabalho de Geertz, enfatiza a importância de se descobrir o native's point of view. O foco está na linguagem e símbolos como as principais ferramentas para compreender a perspectiva nativa (original). No entanto, a antropologia cognitiva, representada por Goodenough, difere-se do anterior em relação ao método. Para esta visão, cultura é um sistema de regras ou padrões para perceber, acreditar e agir que todos precisam saber para se manterem membros da cultura. Cabe salientar que os elementos componentes da cultura para um antropólogo tais como linguagem, rituais, estrutura social se desenvolvem ao longo de décadas ou séculos.

Entre as contribuições dos antropólogos, destaca-se a definição de Lévi-Strauss (s.d. apud CAVEDON, 2008), na qual a cultura pode ser compreendida como um sistema simbólico que para serem compreendidos é necessário relacioná-los com o sistema total no qual estão inseridos.

Entretanto, a sociologia compreende a cultura como um complexo que inclui conhecimento, crença, arte, moral, lei, costume e quaisquer outras capacidades e hábitos adquiridos pelo homem na condição de membro da sociedade. Ouchi e Wilkins (1985) perceberam que a maior influencia no âmbito organizacional são os estudos de mitos e ritos, interação simbólica, etnografia e o estudo das organizações como instituições.

Para Pettigrew (1979, p. 574), a cultura representa um sistema de significados aceitos pública e coletivamente por um dado grupo, em um dado tempo. Este sistema de termos, formas, categorias e imagens interpretam para as pessoas as suas próprias situações. Para o autor, a relação é de mão dupla, ou seja, "o homem faz a cultura e a cultura faz o homem".

Bourdieu (1989) apresenta a cultura como formas de se fazer, sentir e pensar, características de uma coletividade humana. Acrescenta ainda que a cultura se apresenta como o conjunto de 
valores, normas e práticas adquiridas e repassadas por um determinado grupo de pessoas, as quais englobam concepções divergentes.

Assim, a partir de tais concepções, Canclini (2005, p. 41) define cultura como "o conjunto dos processos sociais de significação ou, de um modo mais complexo, o conjunto de processos sociais de produção, circulação e consumo da significação na vida social”.

Canclini (2005) destaca o conceito de cultura diante das perspectivas atuais do mundo, estruturalmente marcado pela globalização, mergulhando em contribuições da antropologia, sociologia e comunicação. Explora a multiplicidade do significado da cultura, apresentando duas vertentes principais. A primeira abordando o senso comum sobre cultura, na qual é concebida como "o acúmulo de conhecimentos e aptidões intelectuais e estéticas", criticando a distinção radical entre civilização e cultura. Contrapondo-se ao senso comum, apresenta as propostas de usos científicos, os quais separam e analisam a cultura diante de outros referentes, principalmente nos termos natureza-cultura e sociedade-cultura.

Uma das maneiras de as empresas expandirem no contexto internacional é por meio das fusões e aquisições de empresas estrangeiras. Nestas situações, as interações interculturais são mais relevantes visto que o desafio não será somente em relação à cultura nacional, mas também a cultura organizacional da empresa envolvida (HOFSTEDE, 2005), cujos conceitos são apresentados a seguir.

\subsection{1 - Cultura nacional}

Refletindo sobre o conceito cultura de uma maneira mais pragmática, o impacto de culturas nacionais sobre a gestão das empresas tem sido objeto constante de trabalhos científicos. Diversos autores como Hofstede (2001), House et al (2004), Ronen e Shenkar (1985) e Inglehart (1997) desenvolveram diferentes abordagens conceituais e esquemas classificatórios, mostrando que as culturas nacionais diferem quanto aos pressupostos culturais existentes e demonstram consequentemente, valores, comportamentos e artefatos distintos. Assim, entende-se que a iniciativa pode ser influenciada também pela cultura local.

Segundo Tung (2008), a maioria dos estudos sobre gestão intercultural continua apresentando duas limitações: consideram a cultura nacional como homogênea, não evidenciando as 
significantes diferenças internas dentro de um país, bem como o fato de que existe uma estabilidade ao longo do tempo, ou seja, a cultura não muda.

Em parte, isso é decorrência da visão convergente, que considera que os países desenvolvidos economicamente determinam um modelo de gestão, o qual pode ser seguido pelos demais países do mundo. Esta teoria defende uma racionalidade estrutural que seria encontrada em várias sociedades, independentemente de seu antepassado cultural (TANURE, 2007).

Contrapondo-se, a perspectiva divergente acentua as diferenças de modelos de gestão entre países e regiões, identificando os impactos dessas diferenças sobre os processos gerenciais. A globalização dos mercados não significa, necessariamente, a globalização dos valores culturais (Hofstede et al., 2002). Isto porque cada empresa possui sua própria história, com formas diferenciadas de internalizar mitos e valores, crenças e tradições, princípios e conhecimentos, muitas vezes, decorrentes da cultura nacional.

Um dos fatores mais importantes, das diferenças de cultura de uma empresa em relação a outra, é a cultura nacional. Os pressupostos básicos, os costumes, as crenças e os valores, bem como os artefatos que caracterizam a cultura de uma empresa, trazem sempre, de alguma forma, a marca de seus correspondentes na cultura nacional. Desta forma, não há como estudar a cultura das empresas operantes em uma sociedade sem estudar as culturas desta sociedade.

A cultura é sempre um fenômeno coletivo, Hofstede $(2005$, p. 4) a define como "uma programação coletiva da mente, que distingue os membros de um grupo ou categoria de pessoas face a outro", ou seja, é adquirida, e não herdada, pois provém do ambiente social do indivíduo, não dos genes.

Para Bartlett e Ghosal (1992) a influência da história, a infra-estrutura e a cultura de uma nação permeiam todos os aspectos da vida do país, incluindo o comportamento dos gestores, bem como as normas e valores centrais das subsidiárias. Peng (2008), por sua vez, menciona que a cultura pode também influenciar na escolha estratégica da subsidiária.

Hall (1998) argumenta que as identidades nacionais não nascem com as pessoas, mas são desenvolvidas e transformadas por meio de representações. Assim, o país não é apenas uma entidade política, mas um sistema de representação social. 
A cultura corresponde a um sistema de valores e normas que são compartilhados por um grupo de pessoas e que juntos constituem a forma de viver. Valores significam ideias abstratas sobre o que grupo acredita ser bom, direito e desejável, enquanto as normas são regras sociais e orientações que determinam um comportamento apropriado em situações particulares (HILL, 2005). Para este, os valores e as normas de uma cultura não emergem totalmente formados, mas caracterizam-se pela evolução de um número de fatores, incluindo a filosofia política e econômica, religião, idioma, estrutura social e educação (Ilustração 3).

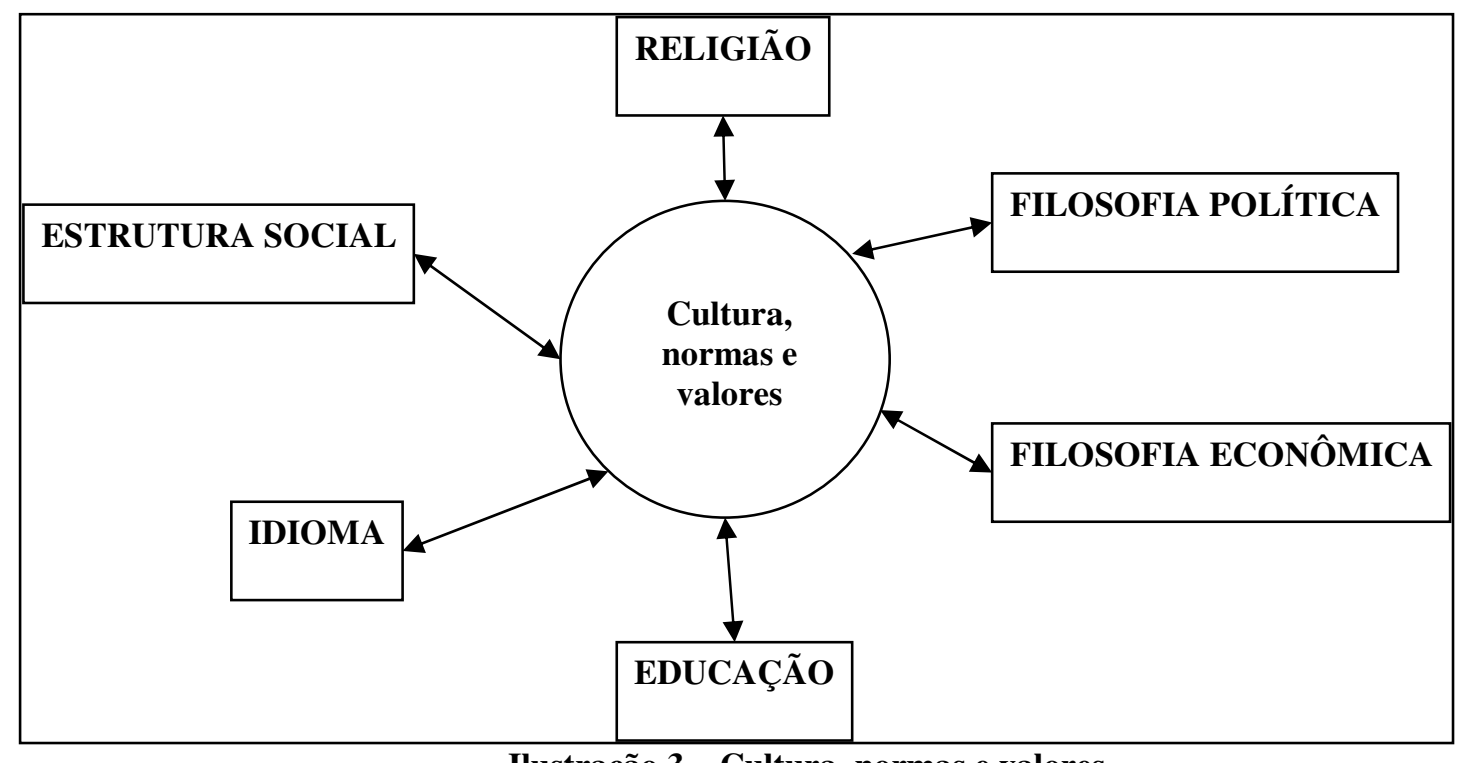

Ilustração 3 - Cultura, normas e valores

Fonte: HILL, 2005.

Corroborando com os inúmeros fatores que formam a cultura, Hofstede (2005) também acentua que as diferenças culturais manifestam-se de diferentes formas: os símbolos, os heróis, os rituais e os valores. Os símbolos são caracterizados pelas palavras e gestos que expressam um significado particular, reconhecido somente pelas pessoas que partilham a cultura; enquanto que os heróis são as pessoas reais ou imaginárias que possuem características valorizadas em uma determinada cultura e, por isso, servem de referência de comportamento. Os rituais são as atividades coletivas, enquanto os valores representam um sentimento orientado.

Hofstede (2005) pode ser considerado o precursor das pesquisas sobre a interferência dos componentes culturais nacionais na organização das empresas. Sugere que os modelos culturais baseiam-se em sistemas de valores, decorrentes da dimensão individual e coletiva e da própria cultura, que são observáveis e podem ser considerados estáveis. Assim, propôs 
quatro dimensões da cultura nacional, as quais podem ser quantificadas: individualismo e coletivismo, distância do poder, controle de incerteza, masculinidade e feminilidade e a orientação a longo e curto prazo.

A dimensão distância do poder representa a percepção do grau de desigualdade entre aquele que detém o poder e aquele que se vê submetido. Hofstede (2001) evidenciou que os países mais populosos e mais pobres tendem a ter índice de distância de poder mais alto.

Segundo Hofstede (2005), nos países com alto índice de distância do poder, as organizações caracterizam-se pela centralização de poder em poucas pessoas e os subordinados esperam que seja dito o que precisam fazer. O Quadro 7 apresenta uma síntese comparativa das principais características de um ambiente de trabalho com alta e baixa distância do poder.

Quadro 7 - A dimensão distância do poder no ambiente de trabalho

\begin{tabular}{|c|c|}
\hline Baixa distância do poder & Alta distância do poder \\
\hline $\begin{array}{c}\text { Hierarquia nas organizações significa uma } \\
\text { desigualdade de papéis, estabelecido por } \\
\text { conveniência }\end{array}$ & $\begin{array}{l}\text { Hierarquia nas organizações reflete uma desigualdade } \\
\text { existente entre os níveis mais altos e os mais baixos }\end{array}$ \\
\hline Descentralização & Centralização \\
\hline Poucos supervisores & Muitos supervisores \\
\hline $\begin{array}{c}\text { Pouca diferença salarial entre o topo e a base da } \\
\text { organização }\end{array}$ & $\begin{array}{c}\text { Grande diferença salarial entre o topo e a base da } \\
\text { organização }\end{array}$ \\
\hline $\begin{array}{l}\text { Os gestores contam com suas experiências e seus } \\
\text { subordinados }\end{array}$ & $\begin{array}{l}\text { Os gestores contam com os seus superiores e as normas } \\
\text { formais }\end{array}$ \\
\hline Os subordinados esperam ser consultados & Os subordinados esperam que digam o que devem fazer \\
\hline O chefe ideal é um democrata & $\begin{array}{l}\text { O chefe ideal é um autocrata benevolente ou um "bom } \\
\text { pai" }\end{array}$ \\
\hline $\begin{array}{l}\text { A relação entre superior e subordinado é } \\
\text { pragmática }\end{array}$ & A relação entre superior e subordinado é emocional \\
\hline Privilégios e símbolos de status são desaprovados & Privilégios e símbolos de status são normais e populares \\
\hline
\end{tabular}

Fonte: Adaptado de HOFSTEDE, 2005, p. 59.

$\mathrm{O}$ fato de as pessoas possuírem suas atividades e responsabilidades bem definidas representa uma organização cujas funções são bem estáveis, na qual a estrutura hierárquica reflete uma desigualdade entre os níveis mais altos e mais baixos do organograma.

Outra característica das organizações de países com alta distância do poder é a determinação das tarefas que precisam ser realizadas, resultado da dependência considerável dos subordinados face às suas chefias, além de uma elevada distância emocional entre as partes 
fazendo com que os subordinados dificilmente abordem ou contradigam as suas chefias abertamente.

O índice de individualismo representa o tipo de relações entre sujeito e seu grau de dependência aos grupos ou às empresas a que eles pertencem. Nas sociedades individualistas, os indivíduos são promovidos considerando-se suas competências e as regras organizacionais; enquanto nas sociedades coletivistas se privilegia o tempo, a experiência na empresa, além da concessão de empregos a familiares ser uma prática comum.

Logo, de um lado, nas sociedades individualistas, as pessoas valorizam condições ambientais e materiais, indicado por buscar incessantemente metas e ganhos financeiros. Do outro lado, nas sociedades coletivistas, as pessoas tendem a trabalhar em grupos, em assumir responsabilidades conjuntamente.

Como individualistas, são identificadas as sociedades em que há poucos laços entre os indivíduos e as pessoas se definem como indivíduos. O coletivismo, ao contrário, caracteriza as sociedades nas quais as pessoas são interligadas e as redes sociais são profundas. É interessante mencionar que quanto mais rico for um país, mais forte será o individualismo (HOFSTEDE, 2005).

Os estudos do autor evidenciaram uma correlação negativa entre essas duas dimensões. Os países com uma grande distância do poder tendem a ser mais coletivistas e os países com pequena distância do poder, mais individualistas.

A terceira dimensão da cultura nacional, a qual se refere ao controle da incerteza, mede o grau de tolerância que uma cultura pode admitir se confrontada ao desassossego suscitado por acontecimentos futuros. Sendo a incerteza uma experiência subjetiva, Hofstede (2001, p. 146) ressalta que "uma incerteza extrema gera uma ansiedade intolerável e cada sociedade desenvolveu mecanismos para aliviar esta ansiedade por meio da tecnologia, das leis ou da religião", ideais transmitidos e reforçados ao longo dos anos pela família, escola e o governo.

Assim, os indivíduos de culturas que possuem elevado índice, como o caso do Brasil, apresentam desconforto perante situações ambíguas, impactando negativamente nos seus comportamentos e tomada de decisão (HOFSTEDE, 2001).

Nos países com elevado nível de controle de incerteza, as pessoas tendem a ser mais inquietas, emotivas, agressivas e ativas; enquanto naqueles nos quais apresentam baixo nível 
de controle de incerteza, as pessoas parecem ser calmas, descontraídas, controladas e indolentes (HOFSTEDE, 2005).

Os mesmos estudos apontam que no ambiente de trabalho, nos países com elevado índice de controle das incertezas existem numerosas leis, formais e informais, que controlam os direitos e deveres dos empregados. Por um lado, nos países com elevado índice de distância do poder, o autor (2001) destaca que o exercício de um poder discricionário por parte dos superiores, substitui, até certo ponto, a necessidade de normas internas. Por outro lado, nos países de baixo índice de controle da incerteza, só se estabelecem normas em casos de absoluta necessidade, existindo uma aversão emocional face às regras formais.

Hofstede (2005) buscou relacionar o controle das incertezas com o individualismo. Suas pesquisas indicam que países coletivistas e com alto controle de incertezas, como o Brasil, têm tendência para eliminar os conflitos intergrupais por meio da negação e tentam assimilar ou reprimir as minorias.

Em relação à quarta dimensão, a qual o estudioso define como masculinidade, salienta-se a forma como a sociedade entende que sejam os papéis dos homens e das mulheres. A dimensão masculinidade representa o quanto os resultados e o sucesso são os valores dominantes na sociedade, estando o trabalho em primeiro lugar, enquanto na feminina, o bem estar e qualidade de vida das pessoas destacam-se, não havendo distinção nos papéis e emoções entre os gêneros.

As principais características das sociedades masculinas são: ter sempre oportunidades para altos ganhos financeiros, obter o reconhecimento merecido quando realiza um bom trabalho, possibilidades contínuas para progresso em um nível mais alto de trabalho e, ter desafios no trabalho a fazer (HOFSTEDE, 2005).

O autor explica que para as sociedades femininas, o destaque fica para: ter um bom relacionamento com o seu superior imediato, trabalhar com pessoas que colaboram umas com as outras e, possuir segurança de que permanecerá no seu trabalho até quando desejar.

Logo, as organizações em sociedades masculinas buscam os resultados e recompensam seus funcionários com base na equidade, cada indivíduo conforme o seu desempenho; enquanto que nas sociedades femininas, as organizações são mais previsíveis e recompensam seus 
funcionários com igualdade, ou seja, cada um conforme suas necessidades (HOFSTEDE, 2005).

Hofstede (2005) propõe a quinta dimensão, relacionada a orientação de curto ou longo prazo, sendo que a sociedade apresentada nesta última, enfatiza a perseverança e a economia visando uma melhoria no futuro. No entanto, diferente das dimensões anteriores propostas pelo autor, esta é muito questionada pelos acadêmicos sobre sua validade.

Em pesquisas do mesmo (2003), as diferenças hierárquicas são mais fáceis de gerir do que as diferenças em relação ao nível de controle de incerteza. Assim, as organizações localizadas em um país de baixa distância hierárquica geralmente têm sucesso nos países de elevada distância hierárquica, visto que o gestor da subsidiária pode adotar um estilo mais autoritário quando comparado à matriz.

As diferenças no índice de controle de incerteza podem representar problemas para as multinacionais visto que as normas têm significados diferentes nos países. Nos países com elevado valor, as pessoas sentem-se desconfortáveis sem a estrutura de um sistema de normas, mesmo que estas sejam impraticáveis.

Vários outros autores também desenvolveram estudos voltados à cultura nacional, destacando-se Leung et al. (2002), Smith et al (1996) e House et al. (2004). Contudo, as dimensões de cultura propostas por estes autores corroboraram em grande parte as dimensões desenvolvidas por Hofstede desde 1980, o que, por sua vez, consolida ainda mais a sua proposta de trabalho diante do entendimento das culturas das nações.

Alguns pesquisadores buscaram classificar os países em grupos com culturas semelhantes como forma de facilitar a análise dos comportamentos dos indivíduos. Por exemplo, Ronen e Shenkar (1985), a partir da geografia, religião, idioma e nível de desenvolvimento econômico e tecnológico, identificaram cinco grupos de países: anglo-americanos, germânicos, latinoseuropeus, latinos-americanos e nórdicos. O Brasil foi classificado como país independente, pois segundo os critérios dos pesquisadores, não apresentou semelhança com nenhum dos grupos.

Inglehart (1997) classificou as sociedades partindo da análise de duas dimensões: autoridades (família, instituições religiosas e políticas) e valores motivacionais. Assim, surgiram oito grupos: ex-comunistas, católicos, Europa protestante, países confucionistas, sul da Ásia, 
América Latina e os países de língua inglesa. Nesta classificação, o Brasil faz parte do grupo da América Latina.

Hofstede (1980 apud RONEN; SHENKAR, 1985) utilizou os valores pessoais expressos pela importância dos objetivos no trabalho e estilo dos gestores. Identificou oito grupos de países: Anglo, Germânico, Nórdico, Europa Latina, América Latina, Oriente Próximo, Extremo Oriente e Independentes. O Brasil foi classificado como país latino europeu juntamente com a Argentina, Bélgica, França, Itália e Espanha.

Leite (1981 apud CYRINO et al, 2010) conduziu uma pesquisa brasileira cujo objetivo foi identificar, dentre 32 países, quais se apresentavam similares ao Brasil em relação à cultura. Constatou que somente Portugal, Uruguai e Argentina caracterizam-se como culturalmente mais próximos ao Brasil, seguido pelos demais países de cultura latina.

Outros estudos buscaram identificar características culturais brasileiras que influenciam de certa forma nos negócios internacionais. Os resultados destes três estudos são sintetizados e apresentados por Hofstede et al (2010) buscando comparar as diferenças culturais entre as regiões do Brasil, visto a grande extensão geográfica do país e as particularidades regionais decorrentes inclusive de processo de colonização e momentos e formas de desenvolvimento econômico distintos em cada local.

Uma evidência desse estudo é que os estados brasileiros mostraram maior similaridade cultural entre si do que quando comparados aos demais países da América Latina. Em relação às cinco regiões do Brasil, um dos estudos apresentados por Hofstede et al (2010) apontou particularidades que são destacadas no Quadro 8.

\begin{tabular}{|c|c|}
\hline Reoiãa & Quadro 8 - Principais características culturais das regiões brasileiras \\
\hline & \\
\hline Sul & $\begin{array}{l}\text { Europeu, hierárquico, menos formal, mais individualista e mais masculino } \\
\text { (orientação para objetivos) }\end{array}$ \\
\hline $\begin{array}{l}\text { Sudeste + Distrito } \\
\text { Federal }\end{array}$ & Urbano, industrial, densamente povoada e eticamente mista, menos masculino. \\
\hline Centro-oeste & Região de colonos, menos formal \\
\hline Nordeste & $\begin{array}{l}\text { Tropical, herança colonial, pobre, afro brasileiro, menos hierárquico, mais formal, } \\
\text { menos masculino (mais emocional) }\end{array}$ \\
\hline Norte & $\begin{array}{l}\text { Predominância de índios nativos na Amazônia, muito informal, coletivista, muito } \\
\text { masculino (assertividade) }\end{array}$ \\
\hline
\end{tabular}

Fonte: Elaborado a partir de HOFSTEDE et al, 2010. 
Dessa maneira, observa-se que a cultura nacional é um fator relevante, mas também que as particularidades regionais precisam ser consideradas e provavelmente influenciam diretamente na forma de gestão das organizações, tanto no contexto nacional quanto no internacional.

\subsection{2 - Cultura organizacional}

A cultura de uma organização está sujeita às influências da cultura de seu país. Ou seja, analisando os modelos de gestão pode-se perceber que os relacionamentos, as relações de poder e o processo de tomada de decisão de uma organização são marcados pelos traços da cultura nacional. Assim, é possível dizer que a cultura nacional influencia a formação da cultura organizacional e esta pode variar entre as mesmas organizações, em diferentes países.

A cultura organizacional passou a adquirir importância quando se atribui o sucesso da economia e administração japonesas não só aos aspectos racionais da gerência japonesa, mas, principalmente, aos seus aspectos tácitos que dificilmente poderiam ser copiados na íntegra em outros contextos.

Uma das discussões mais interessantes sobre a cultura organizacional foi apresentada por Smircich (1983) ao mencionar dois tipos de abordagens. A cultura organizacional pode ser considerada uma variável da organização, ou seja, algo que esta possui ou, de maneira metafórica, a cultura como sendo a própria organização. Segundo a autora, as metáforas utilizadas visam o melhor entendimento da complexidade das organizações: organismos e máquinas são as principais. Cada metáfora, consequentemente, foca a atenção de maneira seletiva, resultando em diferentes formas de conhecimento.

Para Thevenet (1991), a organização tem uma cultura ao mesmo tempo em que ela é uma cultura. Se por um lado, cada organização possui um conjunto de elementos que lhe são próprios, podendo a cultura ser descrita, por outro, a organização vista como sociedade humana, cria símbolos e signos que se caracterizam como criações coletivas e afirmam a sua existência.

Observa-se nos estudos de cultura organizacional um debate contínuo entre explícito e racional versus implícito e irracional. Alguns pesquisadores defendem que a cultura 
organizacional deve ser compreendida pelos aspectos explícitos e racionais, enquanto outros acreditam que os aspectos implícitos e irracionais são primordiais.

Em relação à distinção entre explícito e implícito, sociólogos admitiram que o estudo de ambas torna-se essencial para a compreensão da vida social. Os mitos, ritos e as representações simbólicas de uma complexa realidade social são fundamentais para a vida coletiva, com expressivo efeito nos estudos de cultura organizacional.

Em relação ao racional versus irracional, é de suma importância entender como as relações informais nas organizações e mesmo as crenças individuais ou coletivas modificam o sistema formal.

Um dos notórios estudiosos sobre cultura organizacional é Schein (1989, p. 12), o qual a define como:

conjunto de pressupostos básicos que um grupo inventou, descobriu ou desenvolveu ao aprender como lidar com os problemas de adaptação externa e integração interna e que funcionaram bem o suficiente para serem considerados válidos e ensinados a novos membros como a forma correta de perceber, pensar e sentir, em relação a esses problemas.

$\mathrm{O}$ autor analisa a cultura organizacional, partindo do pressuposto de que o conceito de cultura resulta de três camadas ou três níveis interativos. O primeiro deles são os artefatos que contemplam todos os fenômenos que podem ser vistos por qualquer indivíduo da organização. Classifica este nível como o mais fácil no que tange a observação, contudo o mais difícil de decifrar. A segunda camada traz a discussão dos valores compartilhados ou esposados, que para o autor são tidas como as informações, ou seja, busca conhecer a forma como as pessoas respondem e se comportam na organização.

Schein (2001) ressalta que empresas com artefatos diferentes e valores compartilhados iguais, não conseguem explicar a cultura a estas, é necessário chegar aos pressupostos ou premissas básicas, que é tido como o terceiro nível da cultura.

Este nível busca explicar coisas que vão além dos comportamentos observáveis e dos valores justificados de forma consciente. As premissas básicas levam ao inconsciente, às crenças que consistem da cultura do próprio grupo e que vão sustentar os seus comportamentos. Schein (2001) defende que a essência da cultura está justamente nestas premissas básicas, e diz que 
este nível sendo compreendido, faz com que os outros níveis superficiais tornem-se facilmente entendidos.

Para Fleury (1996), a definição de Schein é válida, mas acredita que a dimensão política deva ser inserida no conceito de cultura organizacional. Assim, Fleury (1996, p. 22) propõe a cultura como "um conjunto de valores e pressupostos básicos expresso em elementos simbólicos, que em sua capacidade de ordenar, atribuir significações, construir a identidade organizacional [...]".

Apesar de cada empresa delimitar sua própria cultura, com normas e valores particulares, a cultura nacional é um fator muito relevante e de grande influência na cultura organizacional.

\subsection{3 - Cultura organizacional e estilo de gestão brasileiro}

Considerando que o objeto deste estudo é representado pelas subsidiárias de multinacionais brasileiras, torna-se relevante expor algumas características da cultura brasileira e como estas influenciam ou impactam nos estilos de gestão preponderantes nas organizações.

O Brasil foi um dos países estudados por Hofstede (2005) e, os resultados de sua pesquisa apontam para uma sociedade coletivista, contudo não se colocando entre as mais coletivistas. O Brasil é mais coletivista que o Japão, país geralmente tido como coletividade por excelência (HOFSTEDE, 2002).

Também é uma das nações onde é alta a dimensão de controle de incerteza, assim como a distância do poder. Por sua vez, em relação a dimensão da masculinidade, o Brasil encontrase na dimensão masculina, muito próximo da feminina, sendo quase impossível situá-lo com precisão (HOFSTEDE, 2002).

Os resultados das pesquisas conduzidas por Hofstede sobre a relação existente entre os traços de culturas, as nacionalidades e os seus reflexos na cultura das organizações, serviram de base para estudos realizados sobre a cultura organizacional brasileira. Aidar et al. (2004) utilizaram três das quatro dimensões, propostas por Hofstede, para analisar e evidenciar traços de uma possível cultura organizacional brasileira: distância do poder, controle da incerteza e individualismo. 
Em relação à alta distância do poder, Aidar et al. (2004) atribuem ao modelo colonial, centrado no senhor das terras, como elemento histórico para justificar as características culturais e uma estrutura social baseada na desigualdade. Esta situação se reflete "em muitas organizações brasileiras que parece haver mesmo acomodação a um status quo baseado em grandes diferenças sociais" (AIDAR et al, 2004, p. 69), decorrentes da alta distância do poder. Para os autores, mesmo as empresas que passaram por processos de modernização do modelo de gestão, fundamentados em princípios de racionalidade administrativa, continuam apresentando características do sistema hierárquico.

Assim como caracterizado por Hofstede, Aidar et al (2004) enfatizam que o Brasil apresentase como uma das nações com alto controle à incerteza. Sobre o aspecto histórico, os autores destacam a baixa iniciativa a mudanças e a falta de espírito empreendedor, decorrentes da miscigenação dos colonizadores com os povos indígenas, além da influência da igreja católica, que preconiza a obediência e a conformidade.

Tal característica, combinada com a alta distância do poder, parece relacionar-se às sociedades onde as relações pessoais e os processos de trabalho são fortemente guiados por estruturas burocráticas, tradições, normas e leis.

No entanto, os sistemas burocráticos e de leis no Brasil não são iguais para todos os cidadãos, valendo-se de particularidades e ambiguidades, frutos dos relacionamentos pessoais. A busca por um caminho alternativo, da malandragem para fugir do "não pode", foi cunhado por DaMatta (1997, p. 103) como sendo o “jeitinho brasileiro”, onde:

\begin{abstract}
não há no Brasil quem não conheça a malandragem, que não é só um tipo de ação concreta situada entre a lei e a plena desonestidade, mas também, e sobretudo, é uma possibilidade de proceder socialmente, um modo tipicamente brasileiro de cumprir ordens absurdas, uma forma ou estilo de conciliar ordens impossíveis de serem cumpridas com situações específicas [...]
\end{abstract}

Em relação aos países coletivistas, como o Brasil, existe uma maior dependência moral dos funcionários em relação à organização, representadas pela postura paternalista da alta direção. Como sustento histórico, Aidar et al. (2004) apresentam a empresa como extensão das casas grandes e senzalas, nas relações entre o chefe, que provem o sustento do empregado, mas ao mesmo tempo, o castiga e cobra resultados. Com as mudanças organizacionais, esta situação 
está se transformando, mas ainda é possível perceber, em várias empresas, a relação de subordinação entre chefe e empregado.

Motta e Caldas (2007) identificaram cinco traços brasileiros que podem ser analisados no âmbito organizacional: hierarquia, personalismo, malandragem, sensualismo e espírito aventureiro. Sucintamente, estes traços demonstram a tendência à centralização do poder dentro das organizações brasileiras, uma busca e valorização dos relacionamentos pessoais, e uma forte flexibilidade e adaptabilidade dos processos de tomada de decisão.

Outra proposta de leitura sobre a gestão brasileira é apresentada por Tanure e Duarte (2006) por meio de um modelo composto por quatro subsistemas: formal, informal, líderes e liderados. As articulações destes subsistemas originam algumas características relevantes como a concentração de poder, oriunda da força militar tradicionalista; a lealdade pessoal, em que as relações pessoais são superiores às profissionais e a postura de espectador dos subordinados, com manifestações de baixa iniciativa e transferência de responsabilidade para o líder.

É interessante ressaltar que alguns traços identificados por esses autores brasileiros corroboram com os resultados verificados na pesquisa de Hofstede sobre o Brasil. A hierarquia e o personalismo mencionados por Motta e Caldas (2007) e a concentração de poder e as relações pessoais por Tanure (2006), são aspectos que justificam, respectivamente, os índices encontrados nas dimensões de distância do poder e coletivismo.

Segundo Moran et al. (1996), a multiculturalidade tem se tornado característica marcante das equipes de trabalho que se compõem cada vez mais de pessoas de diferentes partes de um país ou de diferentes nacionalidades. Os autores ressaltam que o multiculturalismo é uma importante fonte de vantagem competitiva para as empresas globais, quando estas são capazes de combinar diferentes traços culturais que propiciam inovações, flexibilidade e velocidade necessárias no contexto dinâmico internacional.

Em relação à transferência de conhecimento nas multinacionais, existem alguns estudos que apontam os impactos positivos e negativos que a cultura pode gerar em tal processo; temática que será tratada nos capítulos subsequentes. 


\section{3 - Transferência de conhecimento em multinacionais}

As pesquisas na área da gestão do conhecimento mostram que a habilidade para criar e transferir conhecimentos entre as subsidiárias localizadas em diferentes países e contextos de negócios é uma das vantagens competitivas das corporações multinacionais, além de essencial na gestão do conhecimento. Enquanto a transferência de conhecimento entre departamentos ou filiais num mesmo país parece ser algo simples e mais fácil, está claro que os problemas aparecem quando se associa a distância geográfica e cultural, como no caso da multinacional (BRESMAN et al, 1999).

Gupta e Govindarajan (2000) evidenciaram que as pesquisas em teoria organizacional, teorias econômicas e gestão estratégica têm mostrado que a aprendizagem organizacional é um dos mais importantes tópicos de estudos acadêmicos. Garvin (2000, p. 691) ressalta que as “organizações que aprendem são organizações com habilidade de criar, adquirir e transferir conhecimentos, modificando seu comportamento para refletir esses novos conhecimentos e insights", sendo a habilidade de transferir conhecimentos rápida e eficientemente na organização uma das atividades destacada como sendo primordial para a aprendizagem organizacional.

Birkinshaw (1999) explica que os fluxos de recursos representam o elemento central do desenvolvimento da subsidiária, ligados às iniciativas específicas e também ao seu processo de crescimento contínuo e dentre estes, encontra-se o conhecimento.

Na teoria da criação do conhecimento organizacional de Nonaka e Takeuchi (1997), o conhecimento é definido como uma "crença verdadeira justificada", e na organização, o conhecimento é um recurso intangível que é acumulado pelo aprendizado organizacional.

Uma organização cria e utiliza conhecimento convertendo o conhecimento tácito em conhecimento explícito e vice-versa; sendo que estes não são entidades totalmente separadas, e sim mutuamente complementares e em interação permanente. $\mathrm{O}$ conhecimento explícito é formal e sistemático, facilmente comunicado e compartilhado por meio de especificações de produtos, fórmulas científicas ou programas de computador (NONAKA e TAKEUCHI, 1997). 
Contrapondo-se, o conhecimento tácito, é altamente pessoal e por ser de difícil formalização, sua transferência para outros também é árdua. O conhecimento tácito consiste em parte de habilidades técnicas - o tipo de destreza informal e de difícil especificação, incorporada ao termo know-how e tem importante dimensão cognitiva que consiste na formação dos modelos mentais, crenças e perspectivas tão arraigadas que são tidas como algo certo, não sujeitas à fácil manifestação.

O modelo dinâmico de criação do conhecimento está ancorado no pressuposto crítico de que o conhecimento humano é criado e expandido por meio da interação social entre o tácito e o explícito, denominada pelos teóricos de conversão do conhecimento. Desta maneira, Nonaka e Takeuchi (1997) identificaram quatro modos diferentes de conversão do conhecimento em qualquer organização: socialização, externalização, combinação e internalização.

A socialização é a transferência do conhecimento tácito em tácito. Trata-se da conversão que surge da interação do conhecimento tácito entre indivíduos, principalmente por meio da observação, da imitação e da prática, e a chave para adquirir conhecimento dessa forma é a experiência compartilhada (NONAKA; TAKEUCHI, 1997).

No entanto, a externalização representa a transferência de conhecimento tácito em conhecimento explícito. Consiste em um processo de criação do conhecimento perfeito, na medida em que o conhecimento tácito se torna explícito, expresso pelo uso de metáforas, analogias, conceitos, hipóteses ou modelos. O diálogo e a reflexão coletiva são exemplos de situações que provocam o processo de externalização (NONAKA; TAKEUCHI, 1997).

Quando o conhecimento explícito é transformado em conhecimento explícito, ocorre o que os autores denominam de combinação. É o processo de sistematização de conceitos em um sistema de conhecimento (NONAKA; TAKEUCHI, 1997). O mecanismo de troca pode ser reuniões, conversas por telefone e sistemas de computadores, e torna possível a reconfiguração da informação existente, levando a novo conhecimento.

Para Nonaka e Takeuchi (1997), a internalização é o processo decorrente da transformação de conhecimento explícito em conhecimento tácito. Quando são internalizadas nas bases do conhecimento tácito dos indivíduos sob a forma de modelos mentais ou know-how técnico compartilhado, as experiências pela socialização, externalização e combinação tornam-se ativos valiosos. Para que o conhecimento explícito se torne tácito, é necessária a verbalização e diagramação do conhecimento sob a forma de documentos, manuais ou histórias orais. 
A criação do conhecimento é uma interação contínua e dinâmica entre o conhecimento tácito e o conhecimento explícito. A partir desses processos de criação do conhecimento, forma-se a espiral do conhecimento. A espiral do conhecimento, desenvolvida por Nonaka e Takeuchi (1997) inicia-se com o processo de socialização, seguido da externalização, da combinação e finalmente da internalização que abastecerá o reinício do ciclo. Trata-se de um processo em espiral porque começa no nível individual e vai subindo, ampliando comunidades de interação que cruzam fronteiras entre seções, departamentos, divisões e organizações.

O processo de criação do conhecimento é decorrente dos agentes que participam, bem como da forma que participam. Logo, a existência de um contexto físico é imprescindível para que tal processo ocorra.

Outro aspecto importante é a capacidade de absorção de conhecimento pela subsidiária. Andersson et al (2002) acredita que esta capacidade pode ter um papel estratégico no desenvolvimento de competências por meio da transferência de conhecimento para outras subsidiárias. Lane (2001) enfatiza que a capacidade de absorção da subsidiária é determinada por três fatores: a habilidade para compreender o conhecimento externo, assimilar o conhecimento externo e aplicar o conhecimento externo.

Os fluxos de conhecimentos ocorrem em várias direções e caminhos. O entendimento dos agentes envolvidos, dos artefatos utilizados e dos mecanismos de transformação permite compreender sua dinâmica e os passos necessários para promovê-lo para o sucesso da empresa (NEWMAN, 2003).

A partir das teorias de comunicação, Gupta e Govindarajan (2000) conceituaram fluxos de conhecimento (para dentro ou para fora da subsidiária) em função de cinco fatores: valor do estoque de conhecimento da unidade, disposição motivacional da unidade fonte, existência e eficiência dos meios de transmissão, disposição motivacional da unidade de destino e capacidade de absorção da unidade de destino.

Garvin (2000) enfatiza que para aprender mais sobre o local, o conhecimento deve fluir eficaz e eficientemente rápido na organização. Para isto, existem diferentes mecanismos de transferência do conhecimento, todos com aspectos positivos e negativos.

Chai et al (2003) identificaram, em estudos anteriores, que os principais mecanismos de compartilhamento de conhecimento entre a matriz e subsidiárias são representados por 
diferentes métodos, processos ou procedimentos, tais como: designação de tarefas para outras unidades por um período; fóruns internacionais anuais; interação eletrônica; equipes internacionais; centro provedor de informações; fluxos de pessoas (expatriação); uso de sistemas e ferramentas comuns; regras, procedimentos, relatórios e manuais; bem como encontros internacionais para um projeto específico.

Pesquisas realizadas por Sumelius e Sarala (2008) evidenciaram que a transferência de conhecimento técnico contribui para o desenvolvimento da subsidiária, enquanto a transferência de conhecimento de negócios não apresenta significativo efeito no desenvolvimento desta. Assim, os resultados sugerem que a subsidiária é capaz de aprender com o seu ambiente e que seus parceiros externos têm um papel importante no seu desenvolvimento.

No entanto, cabe destacar a questão do tempo de existência da subsidiária na transferência de conhecimento. Segundo Birkinshaw et al (2002), as subsidiárias mais velhas têm mais tempo para criar mecanismos e relacionamentos para compartilhar conhecimentos.

Em relação às multinacionais brasileiras, Oliveira Junior e Borini (2010) evidenciaram que os mecanismos de transferência de conhecimento nessas empresas diferem-se dos adotados pelas multinacionais de outros países. Observaram, portanto, que o fluxo de conhecimento ocorre mais intensamente da matriz para as subsidiárias, indicando que as matrizes brasileiras devam valorizar mais o conhecimento das unidades, promovendo a utilização de ferramentas de gestão.

\subsection{1 - As barreiras à transferência de conhecimento}

No processo de transferência de conhecimento entre a matriz e as subsidiárias de multinacionais são utilizados muitos mecanismos visando otimizar o processo e com isso, aumentar a vantagem competitiva da organização. No entanto, nem sempre este processo ocorre de forma eficaz e eficiente visto a existência de diversos fatores, dentre estes, as barreiras.

As pesquisas quando analisam características do processo de transferência do conhecimento, destacam a relevância das barreiras de comunicação. Holden e Von Kortzfleisch (2004) 
apresentam três aspectos que afetam a transferência de conhecimento entre culturas distintas: a ambiguidade da mensagem, a interferência da linguagem, visto que palavras com grafia semelhante em dois idiomas apresentam sentidos diferentes e, o propósito e prioridade do conhecimento pelas unidades da multinacional (matriz e subsidiárias).

Bhagat et al (2002) evidenciaram que a transferência de conhecimento no âmbito internacional é mais efetivo quando o conhecimento a ser transferido é simples, explicito e independente e, envolve contexto cultural similar. Caso contrário, o processo de transferência do conhecimento torna-se ineficiente e improdutivo.

Ang e Massingham (2007), analisando pesquisas anteriores sobre a gestão internacional do conhecimento, apresentam uma compilação dos fatores que podem facilitar a transferência de conhecimento, salientando que estes podem se tornar barreiras quando não existentes. Por serem muitos, os autores organizaram os fatores em categorias: fatores culturais, fatores organizacionais, característica do conhecimento e gestão do conhecimento.

Dentre essas categorias, torna-se relevante destacar os fatores organizacionais, compreendidos pelo mecanismo de controle da matriz, o modelo de liderança, a similaridade estratégica entre a matriz e a subsidiaria, os incentivos baseados na capacidade de aprendizagem, a gestão de pessoas e a cultura organizacional (ANG; MASSINGHAM, 2007).

Gupta e Govindarajan (2000) apresentam alguns fatores que podem ser facilitadores ou barreiras no processo de transferência de conhecimento entre a matriz e as subsidiárias: valor do estoque de conhecimento da unidade, disposição motivacional tanto da unidade fonte (emissora) do conhecimento quanto da unidade de destino (receptora), existência e eficiência dos canais de transmissão e capacidade de absorção da unidade de destino.

O valor e relevância do estoque de conhecimento da unidade é um deles. O conhecimento criado por uma subsidiária precisa ser inédito e atrativo para as demais unidades, demonstrando uma possibilidade de vantagem relativa. Ou seja, caso a matriz não perceba uma real vantagem na aquisição do conhecimento da subsidiária, não fará nenhum esforço para captar (GUPTA; GOVINDARAJAM, 2000).

Em relação à disposição motivacional para compartilhar conhecimento, pode ser decorrente de uma postura tanto da matriz quanto da subsidiária. Por um lado, a questão do poder, onde não há uma disposição em transmitir conhecimentos com o receio de perder controle sobre as 
atividades. A outra faceta diz respeito à síndrome do "não inventado aqui", ou seja, a matriz ou as subsidiárias criam uma barreira em aceitar ideias e conhecimentos gerados em outra subsidiária (GUPTA; GOVINDARAJAM, 2000).

Segundo Gupta e Govindarajan (2000), existem dois argumentos para a síndrome do "não inventado aqui": mecanismo de autodefesa, quando os gestores bloqueiam quaisquer informações que possam sugerir que as demais unidade são mais competentes que a deles e, lutas internas de poder, quando gestores tentam desqualificar o potencial das unidades, fingindo que o estoque de conhecimento destas não é único e valioso.

Ainda em relação à disposição motivacional, Gupta e Govindarajan (2000) enfatizam que deva existir um sistema de incentivo vinculado à gestão do conhecimento entre as unidades que as mobilize e otimizem a realizar os processos de compartilhamento e valorização do conhecimento.

Outro aspecto destacado pelos autores é a existência de mecanismos de comunicação eficazes, destacando os canais formais e informais na organização. Acreditam que o aspecto da comunicação evidencia questões relacionadas à estrutura organizacional, podendo ser mais centralizada ou descentralizada, impactando na transferência de conhecimento entre as unidades.

Assim como Gupta e Govindarajan (2000), Minbaeva et al (2003) destacaram o aspecto da capacidade de absorção das unidades como sendo uma potencial barreira para os processos de gestão do conhecimento. A capacidade de absorção representa a habilidade de reconhecer o valor de uma nova informação externa, a fim de assimilá-la e aplicá-la nos processos gerenciais.

Essa capacidade de absorção está diretamente relacionada aos colaboradores de uma organização e compreende dois elementos: conhecimento prévio e a intensidade do esforço. $\mathrm{O}$ conhecimento prévio é fruto da formação, experiência e desenvolvimento dos colaboradores ao longo dos anos, enquanto a intensidade do esforço está relacionada à questão motivacional dos funcionários e o seu impacto direto à produtividade organizacional (GUPTA; GOVINDARAJAM, 2000).

Existem pelo menos duas razões por que a capacidade de absorção pode ser diferente entre as organizações: a extensão dos conhecimentos relacionados e a extensão do relacionamento 
entre as unidades de origem e destino. Nesta questão do relacionamento, está representado o quanto os indivíduos de diferentes países que interagem são similares em certos atributos, como crenças, educação, classe social e outros (GUPTA; GOVINDARAJAM, 2000).

Os autores alertam, no entanto, que a síndrome do "não inventado aqui" é considerada a maior barreira na transferência de conhecimento no âmbito das multinacionais.

\subsection{2 - A estratégia de entrada e a transferência de conhecimento}

As multinacionais utilizam diferentes modos de entrada no mercado global, ou seja, "um arranjo institucional que torna possível a entrada de produto, tecnologia, habilidade humana e gestão e outros recursos dentro de um país estrangeiro" (ROOT, 1994, p. 5).

Hitt et al (2008) apresentam os meios de entrada no mercado internacional (Quadro 9), permeando: exportação; licenciamento; alianças estratégicas (da qual a joint-venture é o caso mais relevante); aquisição; investimentos greenfield; os quais apresentam vantagens e desvantagens.

Quadro 9 - Métodos de entrada no mercado global

\begin{tabular}{|c|l|}
\hline Tipo de entrada & \multicolumn{1}{|c|}{ Característica } \\
\hline Exportação & Custo alto, pouco controle \\
\hline Licenciamento & Custo baixo, pequeno riso, pouco controle, baixos retornos \\
\hline Alianças estratégicas & Custos, recursos, riscos compartilhados e problemas de integração \\
\hline Aquisição & $\begin{array}{l}\text { Acesso rápido ao novo mercado, custo alto, negociações complexas, problemas de } \\
\text { fusão com operações locais }\end{array}$ \\
\hline $\begin{array}{c}\text { Nova subsidiária } \\
\text { integral }\end{array}$ & $\begin{array}{l}\text { Complexa, geralmente dispendiosa, demorada, de alto risco, controle máximo, } \\
\text { retornos potenciais acima da média }\end{array}$ \\
\hline
\end{tabular}
Fonte: HITT et al, 2008, p. 223.

Para o presente estudo, torna-se relevante explorar as características das subsidiárias oriundas de aquisições e a opção de início de uma nova unidade integral (greenfield), bem como suas particularidades na transferência de conhecimento com a matriz.

Hitt et al (2008) revelam que as negociações internacionais com objetivo de aquisição são, na maioria das vezes, complexas visto que dependem das exigências legais do país da empresaalvo, além de um ambiente de culturas corporativas distintas, acrescido de práticas culturais e sociais específicas do país. O método mais complexo é o estabelecimento de uma nova subsidiária integral (greenfield venture). Apesar do alto custo e complexidade, garante à 
corporação o controle total da gestão, oferecendo potenciais retornos para a corporação (HITT et al ,2008).

Meyer et al (2009), utilizando-se da visão baseada em recursos, consideram que além de aproveitar os recursos existentes, investimentos estrangeiros significam ampliar os recursos da empresa com a exploração dos conhecimentos existentes por meio da aprendizagem organizacional (internamente) e o acesso a conhecimentos complementares, locais (externo). Especificamente, entradas por meio de aquisições permitem acesso a recursos complementares.

Bresman et al (1999) estudaram a gestão do conhecimento em organizações internacionais adquiridas. Segundo os autores, a literatura sobre gestão do conhecimento tem mencionado o potencial de aquisições como um ganho de novos conhecimentos e a literatura sobre aquisição tem demonstrado a importância da transferência destes nas aquisições para a criação de valor.

Esse aspecto é enfatizado também por Bjorkman (2004), ao relatar que um motivo importante da multinacional adquirir uma empresa local pode ser o acesso à conhecimento de base. Enfatiza que, comparado com subsidiárias greenfield, unidades adquiridas podem possuir conhecimentos mais exclusivos e diferenciados no contexto da multinacional.

Em relação à transferência de conhecimento entre as subsidiárias, Gupta e Govindarajan (2000) evidenciaram que unidades adquiridas transferem mais conhecimento para outras subsidiárias e para a matriz do que as unidades greenfield. Isto porque nas unidades provenientes de aquisições pode-se esperar que haja um estoque de conhecimento que é menos duplicado (repetido) do que o do resto da corporação, fazendo com que tenham maior relevância de conhecimento a oferecer para a rede global do que a subsidiária de greenfield. Por outro lado, os autores evidenciaram que as subsidiárias greenfield possuem uma capacidade de absorção de conhecimento de outras unidades superior a das unidades adquiridas.

Bresman et al $(1999,2010)$ constataram que nos anos iniciais, pós aquisição, que a transmissão do conhecimento, ocorre mais do adquirente (matriz) para o adquirido (subsidiária), de maneira impositiva, sendo baixo o nível de transferência no outro sentido. A principal razão é a falta de relacionamento entre indivíduos das duas unidades, tornando a confiança nas habilidades do outro algo difícil. A distância cultural também aparece como um fator, pois podem existir mal-entendidos entre os indivíduos nos primeiros anos de aquisição. 
No entanto, nos estágios mais avançados, a partir do terceiro ano após a aquisição, os autores perceberam que a transferência de conhecimento passou a ser recíproca, em ambas as direções, decorrentes de desenvolvimento de projetos conjuntos (BRESMAN et al, 2010).

O Quadro 10 apresenta as principais características evidenciadas a partir da literatura sobre a transferência de conhecimento em subsidiárias oriundas de aquisição e de greenfield.

\begin{tabular}{|} 
Quadro 10 - Principais características da transferência de conhecimento em relação a forma de entrada \\
\begin{tabular}{|c|l|}
\hline Subsidiária & \multicolumn{1}{c|}{ Principais características } \\
\hline \multirow{3}{*}{ Aquisição } & $\begin{array}{l}\text { - ganho de novos conhecimentos } \\
\text { - benéfico para criação de valor organizacional } \\
\text { - possibilidade de existência de mal-entendidos } \\
\text { - num primeiro momento, maior transferência de conhecimento da matriz para a } \\
\text { subsidiária }\end{array}$ \\
\hline \multirow{2}{*}{ Greenfield } & $\begin{array}{l}\text { - não dispõe de tanto conhecimento específico do local } \\
\text { - baixa possibilidade de replicar conhecimento para o resto da corporação }\end{array}$ \\
\hline
\end{tabular}
\end{tabular}

Considerando as diferentes formas de entrada em um país, observa-se que em termos de geração e aproveitamento do conhecimento local, a aquisição é mais promissora; no entanto, pode haver outras dificuldades oriundas do processo, como diferenças nas políticas e práticas organizacionais e principalmente choques culturais.

\subsection{3 - A cultura nacional e a transferência de conhecimento}

Apesar de a cultura nacional e gestão do conhecimento constituírem temas pesquisados na gestão internacional, são poucos os estudos que abordam as duas temáticas concomitantemente ou buscam identificar uma relação entre os mesmos.

No contexto de estudos internacionais, as pesquisas que apresentam como tema central a cultura nacional, buscam compreender a sua importância na gestão das multinacionais, principalmente no que diz respeito ao impacto na gestão de pessoas, marketing e operações (ANG; MASSINGHAM, 2007).

No entanto, das pesquisas realizadas e consultadas, um número muito reduzido têm identificado como a cultura pode afetar à gestão do conhecimento, relacionado com fatores como inovação, pesquisa e desenvolvimento, transferência de tecnologia e processo de ensino e aprendizagem. Observa-se, portanto, que não existe uma unanimidade entre os estudiosos sobre a influência da cultura sobre o processo de transferência de conhecimento. 
Por um lado, alguns pesquisadores não evidenciaram que as diferenças na cultura nacional influenciam na transferência do conhecimento. O estudo realizado por Simonin (1999) sobre alianças estratégicas entre empresas de diferentes países evidenciou que não existe significativa influência da cultura nacional na transferência de conhecimento. Gupta e Govindarajan (2000) também não encontraram evidências sobre o impacto da cultura na transferência de conhecimento da subsidiaria para a matriz.

Por outro lado, alguns pesquisadores argumentam que a adaptação ao contexto local é essencial para a gestão internacional do conhecimento, não podendo existir processos de padronização. Holden (2001) critica a literatura sobre a não consideração das diferenças entre os contextos locais. Para o autor, a cultura é um conhecimento tácito, visto que inclui crenças, modelos mentais e percepções que guiam um grupo. Desta maneira, acredita que a cultura possa ser gerenciada por meio da gestão do conhecimento.

Takeuchi e Nonaka (2008) ao explorarem a gestão do conhecimento, apresentando a espiral do conhecimento e os mecanismos de transferência do conhecimento, explicitaram que a compreensão do contexto, particularmente, do cultural é fundamental para um eficiente processo.

Zhu (2004) sugere que exista um aumento da percepção sobre as diferenças entre as culturas e acredita ser impossível a existência de um conceito e modelo universal de gestão do conhecimento, que possa ser utilizado em qualquer contexto. Assim, a adaptação local, considerando-se aspectos culturais, torna-se fundamental.

Pauleen e Murphy (2005) concordam que a utilização do modelo de gestão do conhecimento que exclui a influência da cultura nacional e regional não apresenta sua potencial eficiência no contexto global.

Corroborando com os autores supracitados, estudos realizados por Voel e Han (2005) e Finestone e Snyman (2005) evidenciaram que as diferenças nas culturas nacionais afetam o compartilhamento de conhecimento. Estes estudos revelam que dimensões da cultura nacionais, tais como o individualismo versus coletivismo impactam na gestão internacional de conhecimento.

Em relação às sociedades coletivistas e individualistas, Bhagat et al (2002) ressaltam que os seus membros diferem na forma de criação e transferência de conhecimentos. Nas culturas 
individualistas, as pessoas tendem a analisar cada informação independente do seu contexto, privilegiando os meios mais formais e a comunicação escrita. Entretanto, nas culturas coletivistas, os indivíduos tendem a considerar o contexto da informação e não se vinculam a questões formais, privilegiando contatos telefônicos ou pessoais.

Em relação ao tipo e forma de criação e transferência do conhecimento, Bhagat et al (2007) evidenciaram que organizações em culturas coletivistas são mais dispostas a interpretar e absorver conhecimento tácito, posto que na cultura individualista, estão mais preparados para os conhecimentos explícitos. Na visão dos autores, organizações localizadas em contextos individualistas preferem externalização e combinação da criação do conhecimento enquanto as organizações coletivistas preferem a solicialização e internalização como modos primários de criação e transferência de conhecimento.

Bhagat et al (2007) sugere as sociedades com alta distância do poder são mais propensas a ter organizações relutantes quanto ao conhecimento oriundo da subsidiária, especialmente quando o tipo de conhecimento pode criar desequilíbrio em manter o status quo. Neste caso, o fluxo de informação é controlado por meio da hierarquia, que pode impedir que determinadas informações cheguem a todos os colaboradores (HOFSTEDE, 2001).

Bhagat et al. (2002) diferenciam a transferência de conhecimento entre as culturas verticais e as horizontais. As culturas verticais representam o que Hofstede (2001) classificou como dimensão da distância do poder. Para Bhagat et al. (2002), o fluxo de informações nas culturas verticais geralmente ocorre de cima para baixo, e nas culturas horizontais, em ambos sentidos.

Conforme mencionado anteriormente, cabe salientar que existem estudos teóricos e empíricos sobre a influência da cultura nacional na transferência de conhecimento entre matriz e subsidiárias somente considerando-se as dimensões da distância do poder e individualismo, propostas por Hofstede (2001). Em relação às demais dimensões não foram apontados estudos que as relacionassem com o processo de gestão do conhecimento internacional.

Os quadros 11, 12 e 13 representam uma síntese dos principais conceitos e ideias referentes à iniciativa da subsidiária, ao processo de transferência de conhecimento e à cultura; essenciais para o desenvolvimento dos capítulos subsequentes. 
Quadro 11 - Síntese das principais ideias referentes à iniciativa da subsidiária

\begin{tabular}{|c|c|c|c|}
\hline & Abordagem & Principais Autores & Principais Ideias / Conceitos \\
\hline \multirow{4}{*}{$\begin{array}{c}\text { Iniciativa da } \\
\text { subsidiária }\end{array}$} & Conceito & $\begin{array}{c}\text { Birkinshaw et al }(1998,1999,2002), \\
\text { Birkinshaw e Fry }(1998)\end{array}$ & $\begin{array}{l}\text { - O diferencial de uma subsidiária é a sua iniciativa de desenvolvimento do negócio (BIRKINSHAW et al, } \\
\text { 1998, p. 225), ou seja, a "proativa e deliberada busca por novas oportunidades de negócios pela subsidiária a } \\
\text { fim de expandir seu escopo de responsabilidade, estando alinhada como os objetivos estratégicos da } \\
\text { corporação" } \\
\text { - a iniciativa reflete a postura da matriz de encorajar ou não os esforços da subsidiária }\end{array}$ \\
\hline & $\begin{array}{l}\text { Modelo de análise da } \\
\text { iniciativa da subsidiária }\end{array}$ & Birkinshaw ( 1999) & $\begin{array}{l}\text { - Análise em dois níveis: contexto corporativo e contexto da subsidiária } \\
\text { - Dimensões estruturais (conjunto de forças organizacionais que influenciam o processo de definição e } \\
\text { impulsão do negócio) e comportamentais (conjunto de valores e crenças orientadoras, sendo o seu } \\
\text { desenvolvimento responsabilidade da alta direção) } \\
\text { - Dimensões do contexto corporativo: centralização das decisões (estrutural) e credibilidade e comunicação } \\
\text { entre matriz - subsidiária (comportamental) } \\
\text { - Dimensões no contexto da subsidiária: comportamental, liderança e capacidade distintiva } \\
\text { - Contexto ambiental local: clientes, fornecedores, concorrentes e instituições que a unidade interage } \\
\text { - a iniciativa ocorre tanto no contexto corporativo quanto no da subsidiária }\end{array}$ \\
\hline & Tipos de iniciativa & $\begin{array}{l}\text { Birkinshaw (1997), Birkinshaw e Fry } \\
\quad \text { (1998) e Andersson et al (2002) }\end{array}$ & $\begin{array}{l}\text { - Iniciativa interna: identificação de novas oportunidades de negócios dentro dos limites da corporação } \\
\text { - Iniciativa externa: identificação de novas oportunidades de negócios por meio da interação com os clientes, } \\
\text { fornecedores e entidades governamentais no contexto local da subsidiária }\end{array}$ \\
\hline & $\begin{array}{l}\text { Tipologia para } \\
\text { iniciativa }\end{array}$ & Birkinshaw (1995) & $\begin{array}{l}\text { - reconfiguração: Subsidiária que promove a redistribuição dos recursos existentes da empresa ou recursos, que } \\
\text { são utilizados com mais eficácia } \\
\text { - mercado local: Subsidiária que procura desenvolver um novo produto, mercado ou processo por meio as } \\
\text { oportunidades de negócios que são primeiramente identificadas no contexto local da subsidiária } \\
\text { - proposta competitiva: Subsidiária que procura atrair investimento global ou foco em atividades de valor } \\
\text { agregado internacionalmente com suporte (no princípio) da multinacional/matriz } \\
\text { - extensão de mandato: Subsidiária que procura construir um mandato em vigor ou capacidade comprovada } \\
\text { para atender a uma demanda internacional do produto ou oportunidade de mercado }\end{array}$ \\
\hline
\end{tabular}


Quadro 12 - Síntese das principais ideias referentes à transferência de conhecimento

\begin{tabular}{|c|c|c|c|}
\hline & Abordagem & Principais Autores & Principais Ideias / Conceitos \\
\hline \multirow{4}{*}{$\begin{array}{l}\text { Transferência } \\
\text { de } \\
\text { conhecimento } \\
\text { (TC) }\end{array}$} & $\begin{array}{c}\text { Importância da TC para } \\
\text { o desenvolvimento da } \\
\text { subsidiária }\end{array}$ & $\begin{array}{l}\text { Birkinshaw }(1999,2002), \\
\text { Andersson }(2002), \\
\text { Newman }(2003), \\
\text { Sumelius e Saral (2008) }\end{array}$ & $\begin{array}{l}\text { - os fluxos de recursos representam o elemento central do desenvolvimento da subsidiária } \\
\text { - a capacidade de absorção de conhecimento pela subsidiária é fundamental para o negócio da corporação } \\
\text { - é importante promover os mecanismos de compartilhamento do conhecimento entre as unidades } \\
\text { - a subsidiária é capaz de aprender com o seu ambiente local e contribuir para o negócio da corporação } \\
\text { - a transferência de conhecimento é mais intensa nas subsidiárias mais velhas }\end{array}$ \\
\hline & Barreiras a TC & $\begin{array}{l}\text { Bhagat et al (2002), Ang e } \\
\text { Massingham (2007), Gupta e } \\
\text { Govindarajan (2000), Bresman et al } \\
\text { (1999) e Bjorkman (2004) }\end{array}$ & $\begin{array}{l}\text { - a transferência de conhecimento é mais efetiva quando envolve contexto cultural similar } \\
\text { - excesso de controle da matriz, cultura organizacional e falta de incentivos à aprendizagem são barreiras à } \\
\text { transferência de conhecimento } \\
\text { - valor e relevância do estoque de conhecimento da unidade } \\
\text { - principais barreiras: síndrome do "não inventado aqui" e baixa capacidade de absorção da subsidiária }\end{array}$ \\
\hline & $\begin{array}{l}\text { Forma de entrada e a } \\
\text { TC: Unidades } \\
\text { adquiridas x Greenfield }\end{array}$ & $\begin{array}{c}\text { Gupta e Govindarajan (2000), } \\
\text { Bresman et al (2010) }\end{array}$ & $\begin{array}{l}\text { - importância da transferência de conhecimento nas unidades provenientes de aquisições para criação de valor } \\
\text { - unidades adquiridas transferem mais conhecimento do que as greenfield } \\
\text { - as unidades greenfield possuem capacidade de absorção de conhecimento superior } \\
\text { - nos primeiros anos, alta a transferência de conhecimento da matriz para subsidiária que se inverte com o } \\
\text { amadurecimento }\end{array}$ \\
\hline & Cultura e TC & $\begin{array}{c}\text { Zhu (2004, Pauleen e Murphy (2005), } \\
\text { Bhagat et al (2002), Voel e Han } \\
\text { (2005), Finestone e Snyman (2005), } \\
\text { Takeuchi e Nonaka (2008) }\end{array}$ & $\begin{array}{l}\text { - não há um modelo universal de gestão do conhecimento, sendo a adaptação local fundamental } \\
\text { - as culturas coletivistas utilizam meios mais informais e contatos pessoais ou telefônicos e absorvem mais } \\
\text { conhecimento tácito } \\
\text { - as dimensões culturais afetam a transferência de conhecimento } \\
\text { - fluxo de informações nas culturas verticais (alta distância do poder) geralmente ocorre de cima para baixo }\end{array}$ \\
\hline
\end{tabular}


Quadro 13 - Síntese das principais ideias referentes à cultura

\begin{tabular}{|c|c|c|c|}
\hline & Abordagem & Principais Autores & Principais Ideias / Conceitos \\
\hline \multirow{3}{*}{ Cultura } & Cultura Nacional & $\begin{array}{l}\text { Hofstede (2000), Tung (2008), } \\
\text { Tanure e Duarte (2006), Hall (1998), } \\
\text { Bartlett e Ghosal (1992), Hill (2005) }\end{array}$ & $\begin{array}{l}\text { - visão divergente e convergente da cultura no âmbito internacional } \\
\text { - existem diferenças culturais internas num mesmo país, regionais, inclusive no Brasil } \\
\text { - cultura corresponde a um conjunto de valores e normas que são compartilhados por um grupo } \\
\text { - dimensões da cultura: distância do poder, individualismo, controle de incerteza e masculinidade } \\
\text { - existência de tipologias para comparação do Brasil em termos culturais com outros países }\end{array}$ \\
\hline & Cultura organizacional & $\begin{array}{c}\text { Smircich (1983), Schein (1989) e } \\
\text { Fleury (1996) }\end{array}$ & $\begin{array}{l}\text { - duas abordagens sobre cultura: é uma variável da organização ou a própria organização } \\
\text { - conjunto de pressupostos básicos de um grupo e valorizado e repassado a novos integrantes à organização } \\
\text { - três níveis interativos: artefatos visíveis, valores compartilhados e premissas básicas }\end{array}$ \\
\hline & $\begin{array}{l}\text { Cultura e estilo de } \\
\text { gestão brasileiro }\end{array}$ & $\begin{array}{l}\text { Hofstede (2002), Aidar et al (2004), } \\
\text { Motta e Caldas (2007) e Tanure } \\
\text { (2007) }\end{array}$ & $\begin{array}{l}\text { - sociedade coletivista, alta distancia do poder e controle de incerteza } \\
\text { - presença do jeitinho brasileiro } \\
\text { - centralização do poder nas organizações brasileiras, busca e valorização dos relacionamentos pessoais e uma } \\
\text { forte flexibilidade e adaptabilidade dos processos de tomada de decisão } \\
\text { - fundamento histórico econômico para as questões de poder e hierarquia nas organizações brasileiras } \\
\text { - baixa iniciativa e falta de espírito empreendedor, decorrente da influência da igreja católica, que preconiza a } \\
\text { obediência }\end{array}$ \\
\hline
\end{tabular}




\section{3 - FORMULAÇÃO DAS HIPÓTESES E O MODELO DE PESQUISA}

Considerando-se o objetivo deste estudo que foi analisar a influência da transferência de conhecimento e de fatores culturais na iniciativa das subsidiárias de multinacionais brasileiras, a partir das discussões conceituais dos capítulos anteriores, nesta seção explorase a formulação das hipóteses e a construção do modelo de pesquisa.

Visto que a iniciativa da subsidiária é o principal construto do estudo, cabe relembrar que representa a "proativa e deliberada busca por novas oportunidades de negócios pela subsidiária a fim de expandir seu escopo de responsabilidade, estando alinhada com os objetivos estratégicos da corporação" (BIRKINSHAW, 1999, p. 225). Trata-se de uma forma discreta da multinacional utilizar e expandir seus recursos no âmbito internacional.

\section{1 - Hipóteses}

As três hipóteses deste estudo surgiram principalmente mediante às reflexões acerca dos estudos sobre matrizes e subsidiárias de multinacionais e do modelo de Birkinshaw (1999) que propôs uma análise da iniciativa da subsidiária em dois níveis que se relacionam: o contexto corporativo e o contexto da subsidiária.

\section{A transferência de conhecimento e a iniciativa}

$\mathrm{Na}$ visão baseada em recursos, uma subsidiária é concebida como um conjunto de recursos heterogêneos, os quais podem oferecer contribuição potencial para a vantagem específica da firma (BARNEY, 1991; HOLSAPPLE e JOSHI, 2003).

Entretanto, para gerar vantagem competitiva para a subsidiária e mesmo, para a corporação como um todo, é fundamental que a unidade identifique novas formas de gerenciamento (gestão inovadora) e de oportunidades de negócios por meio da iniciativa, ou seja, a unidade deve operar de maneira discreta e proativa para a organização utilizar e expandir os seus recursos (BIRKINSHAW, 1999; RUGMAN e VERBEKE, 2001). 
De maneira geral, esses recursos são classificados em: capital, materiais, mão de obra e conhecimento (HOLSAPPLE e JOSHI, 2003). Birkinshaw (1999) ressalta que os fluxos de recursos representam o elemento central do desenvolvimento da subsidiária, associados às iniciativas específicas e também ao seu processo de crescimento contínuo, destacando-se assim a disseminação de conhecimento no contexto da multinacional.

Gupta e Govindarajan (1991) expõem que essa dinâmica de transferência de conhecimento depende da extensão em que a subsidiária busca absorver (internalizar) o conhecimento oriundo do resto da multinacional e do quanto a subsidiária busca disponibilizar o seu próprio conhecimento para as outras unidades da corporação.

Esses fluxos de conhecimentos ocorrem em todos os sentidos possíveis, entre a matriz e as unidades e mesmo diretamente entre estas e, o aproveitamento e ganho advindos destes conhecimentos dependerão dos meios e dos mecanismos utilizados para suas transferências (NEWMAN, 2003; GUPTA E GOVINDARAJAN, 1991). Muitas vezes podem surgir barreiras tanto na unidade quanto na matriz as quais dificultam a transferência de conhecimento, o que não é bom para a atuação e estratégia da subsidiária.

Por meio da transferência de conhecimento, as unidades desenvolvem a aprendizagem organizacional, buscando soluções e alternativas para melhorar seu desempenho e criar vantagem competitiva. Garvin (2000) enfatiza que para aprender mais, o conhecimento deve fluir eficaz e eficientemente na organização.

À medida que a subsidiária recebe maiores informações da matriz e que tem capacidade para absorver tais conhecimentos, melhor será o seu domínio sobre os produtos, processos e sistemas utilizados pela multinacional, principalmente pela matriz. No contexto local, isto poderá favorecer os seus contatos com clientes, fornecedores e outros, visto que terá maior poder de barganha e de oferecer novos produtos e/ou serviços.

O mesmo acontecerá na perspectiva das iniciativas internas, ou seja, a partir do momento em que a unidade tem o pleno conhecimento sobre o que ocorre nas demais subsidiárias e na matriz, terá maior facilidade na identificação de oportunidades de melhorias para o negócio corporativo. Também, ao transmitir os resultados obtidos pela otimização dos seus recursos (iniciativa) à matriz e as demais unidades, a subsidiária conquistará maior credibilidade. Birkinshaw (1999) ressalta que a credibilidade da subsidiária com a matriz é fundamental para novos processos de iniciativa, assim como o alto nível de comunicação entre as unidades. 
Conforme mencionado por Nohria e Ghoshal (1997), a subsidiária que possui conhecimento é capaz de tomar melhores decisões e, com isso contribuir mais para o seu desenvolvimento eficiente no contexto local e no da multinacional como um todo.

Desta maneira, mediante ao fato de que o conhecimento é um recurso valioso para o desenvolvimento da multinacional, a sua transferência torna-se imprescindível à criação de iniciativa pela subsidiária, caracteriza-se como primeira hipótese deste estudo:

H 1 - A iniciativa da subsidiária é diretamente influenciada pela transferência de conhecimento

\section{$\underline{\text { A cultura e a iniciativa }}$}

A iniciativa da subsidiária foi definida por Birkinshaw (1998) como a busca proativa de novas oportunidades de negócios pela subsidiária, com o objetivo de expandir o seu escopo de responsabilidade, otimizando seus recursos e alinhando-se sempre às estratégias da multinacional.

Assim, a iniciativa caracteriza-se como uma ação empreendedora da unidade diante de seu contexto competitivo local e da corporação como um todo (BIRKINSHAW e FRY, 1998), independentemente do incentivo da matriz (BORINI, 2008). Apresenta-se, ainda, como resultado do modelo de gestão, mais particularmente, da postura dos gestores da subsidiária e de ações internas realizadas; compreendidas como manifestações da cultura da organização.

Para Bartlett e Ghosal (1992) a história, a infra-estrutura e a cultura de uma nação permeiam todos os aspectos da vida de um país, influenciam o comportamento dos gestores, bem como as normas e valores centrais das subsidiárias. Hofstede (2005) enfatiza que culturas nacionais diferem quanto aos pressupostos culturais existentes e demonstram, consequentemente, valores, comportamentos e artefatos distintos, o que reflete na dinâmica organizacional das empresas.

No ambiente de negócios internacionais, a cultura nacional tem sido considerada um fator relevante, Kogut e Singh (1988) e Peng (2008) apontaram como fundamental a sua análise para a tomada de decisão da multinacional quanto a forma de entrada em um outro país. 
Não existem pesquisas que relacionam diretamente a iniciativa com a cultura local da subsidiária, mas alguns estudos demonstraram significativa relação entre características da cultura nacional e os aspectos do empreendedorismo corporativo, o que indica que as características culturais podem transformar e complementar o contexto econômico e institucional da unidade, influenciando o empreendedorismo (HAYTON et al, 2002).

Logo, tanto a cultura do país da unidade internacional quanto a cultura organizacional da matriz, manifestada pelos costumes, hábitos e normas, no contexto da subsidiária influenciará positivamente a iniciativa desta, seja no âmbito da corporação ou no ambiente local fomentada pelas redes de relacionamento. E, assim, tem-se a segunda hipótese deste estudo.

H 2 - A iniciativa da subsidiária é diretamente influenciada pela cultura

\section{$\underline{\text { A transferência de conhecimento e a cultura }}$}

No processo de transferência de conhecimento entre as unidades de uma multinacional, alguns autores distinguem os impactos positivos e negativos que podem ter sido gerados pela cultura (VOEL; HAN, 2005; FINESTONE; SNYMAN, 2005). No entanto, não há unanimidade dos estudiosos sobre esta interferência, ainda que em muitos casos, a cultura tenha sido apontada como um fator facilitador neste processo (TAKEUCHI; NONAKA, 2008; PAULEEN; MURPHY, 2005; BHAGAT et al, 2002).

Holden e Von Kortzfleisch (2004) destacaram que a ambiguidade da mensagem, o sentido diferente de palavras com a mesma grafia e o propósito e prioridade do conhecimento pelas unidades da multinacional (matriz e subsidiárias) são as principais barreiras na transferência de conhecimento entre culturas distintas.

No entanto, a compreensão da cultura se torna primordial no momento em que a adaptação ao contexto local é essencial para a gestão internacional do conhecimento e, não podem existir processos de padronização. Zhu (2004) salienta que é impossível a existência de um conceito e modelo universal de gestão do conhecimento, que possa ser utilizado em qualquer contexto. Assim, a adaptação local, considerando-se aspectos culturais, torna-se fundamental. 
Takeuchi e Nonaka (2008), ao explorarem a gestão do conhecimento, apresentando a espiral do conhecimento e os mecanismos de transferência do conhecimento, explicitaram que a compreensão do contexto, particularmente, do cultural é fundamental para um processo eficiente. Bhagat et al (2002) evidenciaram que a transferência de conhecimento é mais efetiva quando envolve contextos culturais similares.

Considerando a gestão do conhecimento como ferramenta estratégica no âmbito global, tornase fundamental a análise da influência da cultura nacional e regional no processo (PAULEEN; MURPHY, 2005). Logo, apesar dos estudos sobre a influência da cultura diretamente na transferência de conhecimento entre matriz e subsidiárias, em todos os sentidos, ainda ser muito incipiente, as evidências indicam a existência desta relação, a qual será tomada como a última hipótese deste estudo.

H 3 - A transferência de conhecimento é diretamente influenciada pela cultura

\section{2 - Modelo de pesquisa}

O modelo de pesquisa proposto para este estudo está baseado no modelo de iniciativa da subsidiária de Birkinshaw (1999), que considerou tanto o contexto corporativo quanto o contexto local da subsidiária, configurados por dimensões estruturais e comportamentais, no qual a iniciativa da subsidiária é decorrente das inter-relações do contexto corporativo com o seu próprio.

No modelo de Birkinshaw (1999), o contexto corporativo apresenta três dimensões relevantes:

- centralização da decisão;

- credibilidade da subsidiária; e

- comunicação, representando pelas interações pessoais ou por meio da tecnologia existente entre a matriz e a subsidiária.

O contexto corporativo é representado pela matriz e demais unidades estrangeiras, considerando-se apenas a dimensão da comunicação, caracterizada no modelo pelos fluxos de 
conhecimentos direcionados pela sede e reconhecidos pela subsidiária. Esta, por sua vez, também irá criar e disseminar conhecimentos internamente e para as demais unidades da corporação, inclusive para a administração central. Desta interação, resultará a transferência de conhecimento como um todo, um dos construtos do presente estudo.

No modelo original de Birkinshaw (1999), o contexto da subsidiária é formado pelo contexto comportamental, ou seja, o local de trabalho profundamente enraizado na ética empresarial, valorizado pelo empreendedorismo, pela colaboração e pela aprendizagem. $O$ autor não explicita o contexto comportamental como parte da cultura da organização, mas sua definição conduz a esta leitura. Assim, para o modelo proposto por este estudo, o contexto da subsidiária será formado pela transferência de conhecimento e pela cultura local da subsidiária; sendo que esta pode ter sofrido influência da cultura do país e/ou da matriz brasileira e que por sua vez, apresenta aspectos da cultura da nação.

Desta maneira, a interação entre o contexto corporativo e o da subsidiária é fundamental para a iniciativa desta, ou seja, a sua forma de agir e reagir ao ambiente interno (corporativo) será decorrente dos processos de transferência de conhecimento tanto da matriz para a filial, quanto o inverso.

No contexto da subsidiária, além da transferência de conhecimento, devem-se considerar as suas características culturais, decorrentes da cultura do país sede e da matriz. Como fruto dessas relações, oportunidades de negócios para a corporação como um todo poderão ser identificadas, o que se denomina iniciativa interna.

Ao mesmo tempo em que a filial, inserida em seu contexto, relaciona-se com a matriz e demais unidades da corporação, existe um ambiente local externo com características próprias e peculiares. Do relacionamento entre a subsidiária e o seu mercado local, representado pelos clientes, fornecedores, entidades governamentais e setoriais, podem surgir oportunidades definidas neste modelo como iniciativa externa. 


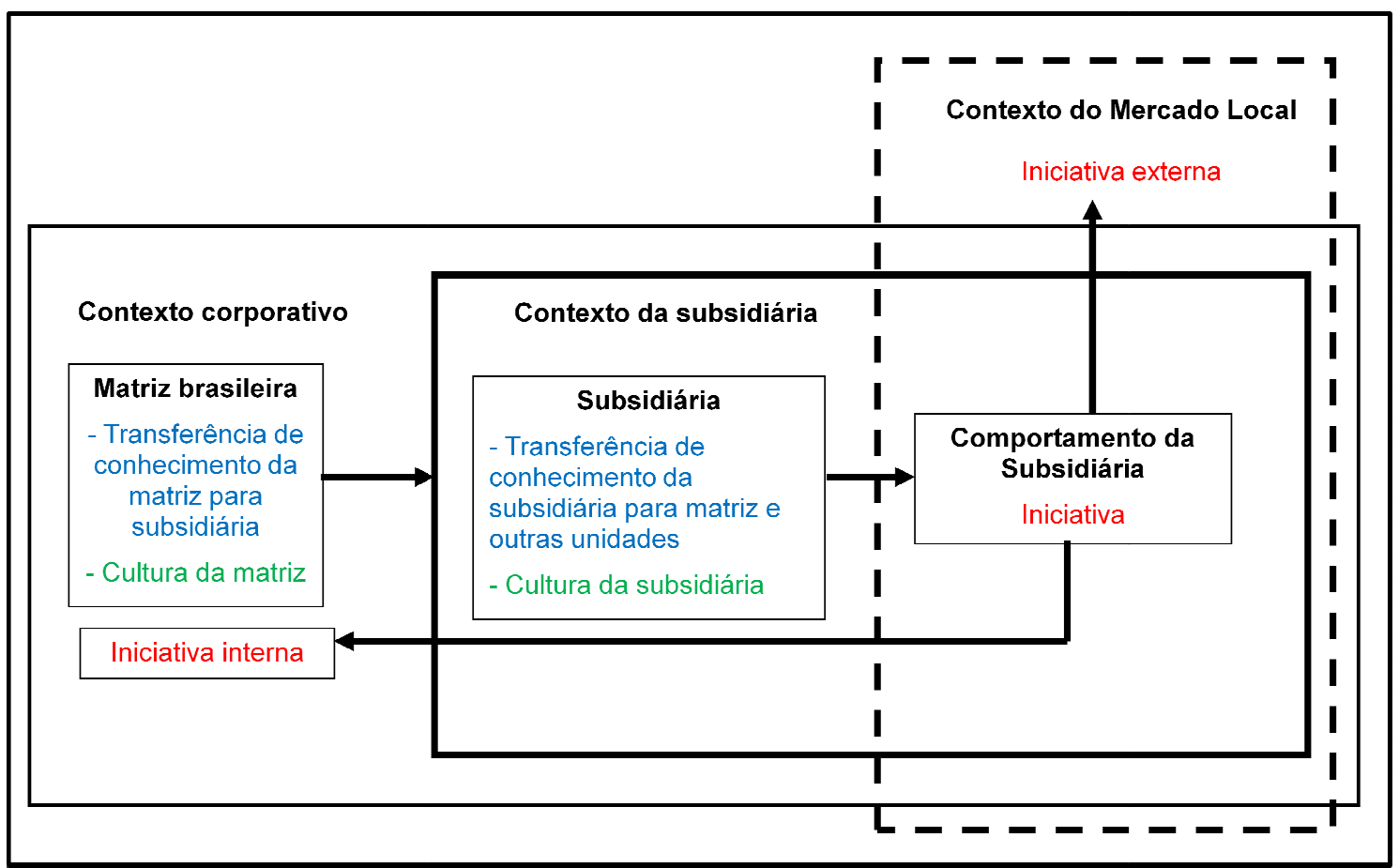

Ilustração 4 - Modelo de pesquisa

Fonte: Elaborado a partir de BIRKINSHAW, 1999.

Portanto, observa-se que as três dimensões que formam o modelo de pesquisa (Ilustração 4) são, conforme definição de Birkinshaw (1999), predominantemente comportamentais: iniciativa da subsidiária, transferência de conhecimento e cultura.

Assim sendo, o contexto da subsidiária, representado pelos construtos transferência de conhecimento e cultura, influenciará positivamente a iniciativa da subsidiária, seja esta no âmbito da corporação ou no local, fomentada pelas redes de relacionamento.

Antes de detalhar o modelo de pesquisa, cabe salientar as definições nominais dos principais construtos aplicadas ao estudo:

A) Transferência de conhecimento é um processo de disseminação de informações, conhecimentos e práticas entre as unidades da multinacional, sendo, desta forma, um construto de terceira ordem, decorrente de dois outros construtos: transferência de conhecimento da subsidiária para matriz e outras unidades e, a transferência de conhecimento da matriz para a subsidiária. Cada um destes processos é o resultado dos mecanismos de transferência utilizados e das barreiras existentes.

Os estudos de Gupta e Govindarajan (2000) sustentam as variáveis que explicam os mecanismos de transferências em ambos os casos: reuniões, manuais, expatriados, 
treinamentos, viagens e ferramentas eletrônicas; enquanto que, para as barreiras ao processo de transferência do conhecimento, são utilizadas as variáveis: dificuldades de integração, estrutura organizacional e falta de reconhecimento pela matriz.

B) Cultura consiste em um conjunto de valores e normas compartilhados por um grupo, organização ou sociedade, representada neste estudo por alguns aspectos culturais da subsidiária; sendo um construto de primeira ordem, formado por variáveis que representam as quatro principais dimensões propostas por Hofstede (2005), e, para analisá-lo: distância do poder, individualismo, controle da incerteza e masculinidade.

C) Iniciativa da subsidiária é a capacidade da subsidiária em vislumbrar oportunidades tanto no âmbito interno da multinacional, quanto no externo, decorrente de seu relacionamento com o mercado local, podendo ser considerada também um construto de segunda ordem, decorrentes de duas abordagens complementares: iniciativas internas e iniciativas externas. Em relação às iniciativas internas, decorrente das relações dentro da corporação, as variáveis utilizadas são: novos produtos desenvolvidos no Brasil e vendidos internacionalmente; aquisição de empresas nacionais conduzidas pela subsidiária; novas atividades de negócios internacionais criadas no país; incremento nas linhas de produtos adotados internacionalmente; e novos investimentos em pesquisa e desenvolvimento ou em processos produtivos (BIRKINSHAW, 1997).

A iniciativa externa está fundamentada na teoria de redes de negócios, ou seja, no relacionamento entre a subsidiária com os seus parceiros estratégicos, representada pelas variáveis: grau de relacionamento com outras subsidiárias da empresa no exterior; unidades de pesquisa e desenvolvimento de outras empresas; empresas de engenharia de outras empresas; universidades ou institutos de pesquisa específicos; fornecedores corporativos preferenciais no país; fornecedores de mercado específicos; com clientes corporativos; clientes do mercado local e com instituições governamentais locais (ANDERSSON; FORSGREN, 2002). 


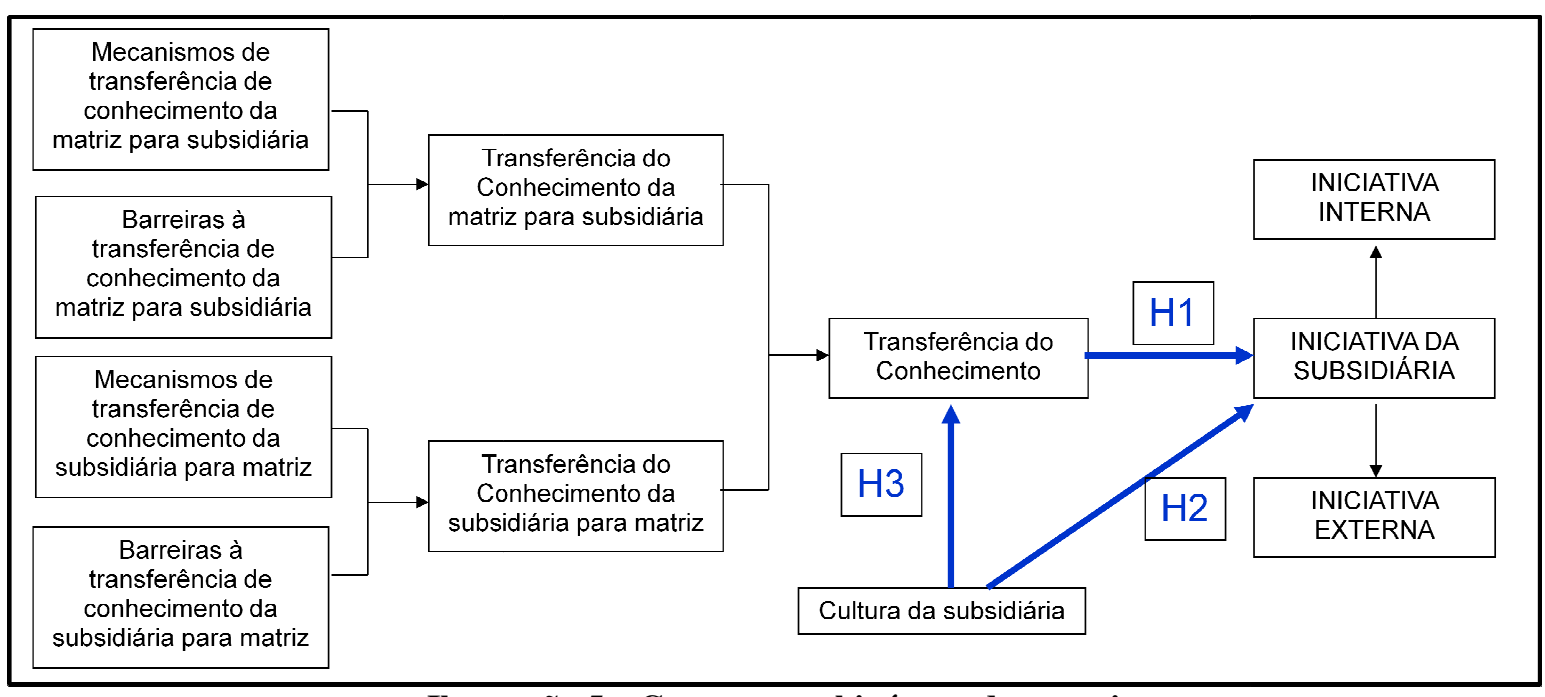

Ilustração 5 - Construtos e hipóteses da pesquisa

A Ilustração 5 apresenta a síntese das relações entre os construtos, bem como as três hipóteses de pesquisa deste estudo. Cabe salientar que, apesar de o modelo estar representado de forma estática, o processo é dinâmico, ou seja, a transferência de conhecimento acontece simultaneamente em ambos os sentidos, permeado pela cultura, além do desenvolvimento de iniciativas pelas subsidiárias e o reconhecimento destas pela matriz. 


\section{4 - PROCEDIMENTOS METODOLÓGICOS}

Neste capítulo são apresentados os procedimentos metodológicos, no que diz respeito à estratégia de pesquisa, aos métodos e às técnicas, que foram utilizados para atingir o objetivo principal deste estudo que é analisar a influência da transferência de conhecimento e de fatores culturais na iniciativa das subsidiárias de multinacionais brasileiras.

A pesquisa foi realizada em dois momentos distintos, os quais tiveram abordagens metodológicas diferentes, porém complementares: quantitativa e qualitativa; visto a amplitude do objetivo geral do estudo, bem como a necessidade de atingir aos objetivos específicos. Creswell (2003) denomina este tipo de estudo como abordagem de métodos mistos.

A articulação de técnicas quantitativas e qualitativas em uma mesma investigação, a pesquisa mista, é uma tendência da pesquisa social, pois possibilita estudos complementares e interessantes, sendo mais completa e efetiva do que as realizadas exclusivamente com uma das duas abordagens (CRESWELL, 2003). Sampieri et al (2006, p. 15) enfatizam que a "mistura dos dois modelos potencializa o desenvolvimento do conhecimento, a construção de teorias e a resolução de problemas".

Nos estudos com emprego de métodos mistos, a integração entre a análise dos dados numéricos e os textuais pode ocorrer de duas formas: concomitante ou sequencialmente. $\mathrm{O}$ primeiro caso acontece quando os dados quantitativos e qualitativos são coletados em um mesmo período de realização da pesquisa de campo; enquanto o estudo em sequência acontece em dois momentos distintos, o pesquisador levanta os dados da segunda fase apenas após ter concluído a etapa inicial, independente se foi quanti-quali ou quali-quanti (CRESWELL, 2003).

Além da sequência de implementação da pesquisa, a prioridade na coleta e análise de dados, o estágio em que os dados e os resultados (quantitativos e qualitativos) são integrados, além da perspectiva teórica, são critérios que Creswell (2003) considera na elaboração de seis estratégias distintas para os estudos de métodos mistos: exploratória sequencial, explanatória sequencial, transformadora sequencial, triangulação concomitante, alinhada concomitante e transformadora concomitante. 
Neste estudo, empregou-se a estratégia sequencial explanatória, a qual Creswell (2003) afirma como sendo a estratégia mais íntegra dentre as abordagens possíveis. É caracterizada pela coleta e análise de dados quantitativos seguida pela coleta e análise de dados qualitativos. Normalmente, os dois métodos (quantitativo e qualitativo) são integrados durante a fase de interpretação do estudo. As etapas do estudo (Ilustração 6) são explicitadas minuciosamente nas próximas seções.

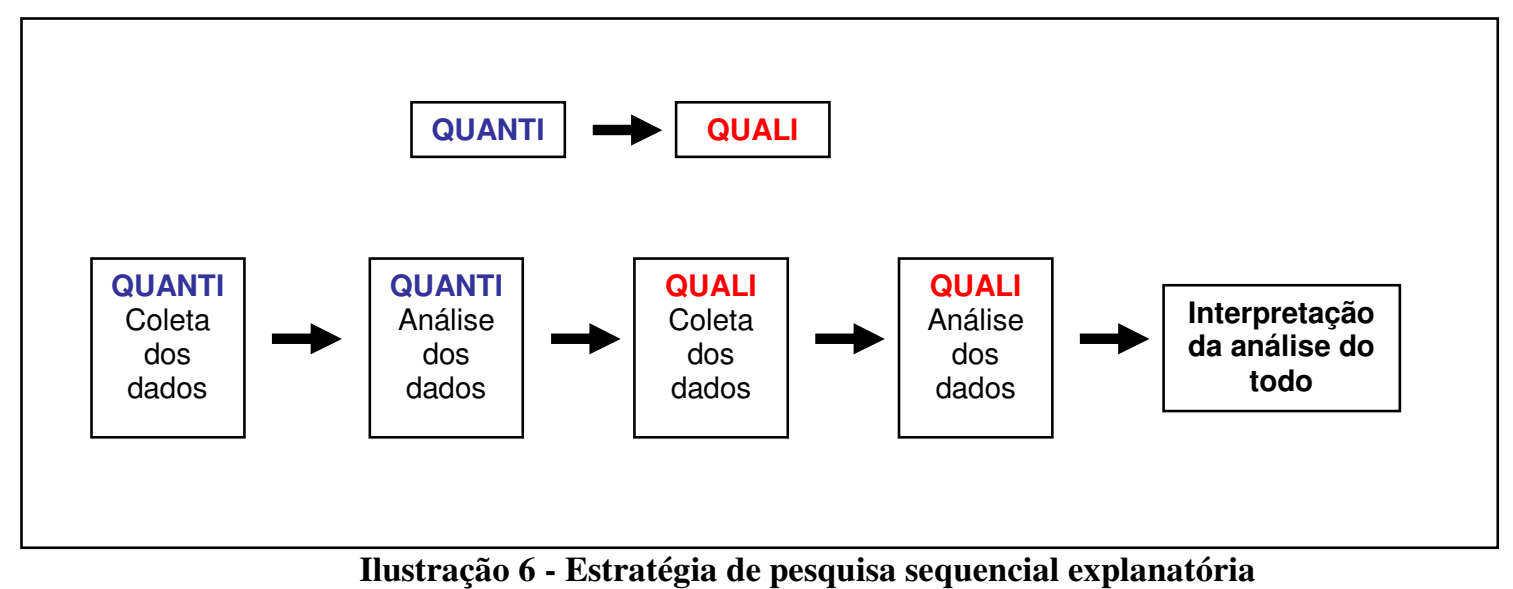

Fonte: CRESWELL, 2003, pg. 213.

O propósito da estratégia sequencial explanatória é utilizar os resultados qualitativos para auxiliar na explicação e interpretação das descobertas feitas no estudo quantitativo preliminar. É aplicada especialmente quando resultados inesperados surgem do estudo quantitativo. Assim, a coleta de dados qualitativos pode ser utilizada para explorar aqueles resultados detalhadamente (CRESWELL, 2003).

Se por um lado, Creswell (2003) salienta que a natureza simples dessa estratégia é um dos seus pontos fortes, fácil de ser implementada porque as etapas são claras, com estágios bem definidos previamente; por outro, o tempo despendido na coleta de dados, com as duas fases distintas, representa sua principal fraqueza.

Assim, no presente estudo, o propósito das duas fases foi obter estatisticamente, em um primeiro momento, resultados quantitativos a partir de uma amostra de subsidiárias de multinacionais brasileiras, atendendo ao objetivo geral e a algumas particularidades dos objetivos específicos delineados; e, em um segundo momento, explorar profundamente esses resultados, por meio de uma abordagem qualitativa aplicada na análise de uma multinacional brasileira, envolvendo a matriz e as respectivas subsidiárias. 
A Ilustração 7 apresenta o desenho geral da pesquisa, relacionando os objetivos específicos com as fases e a abordagens do estudo.

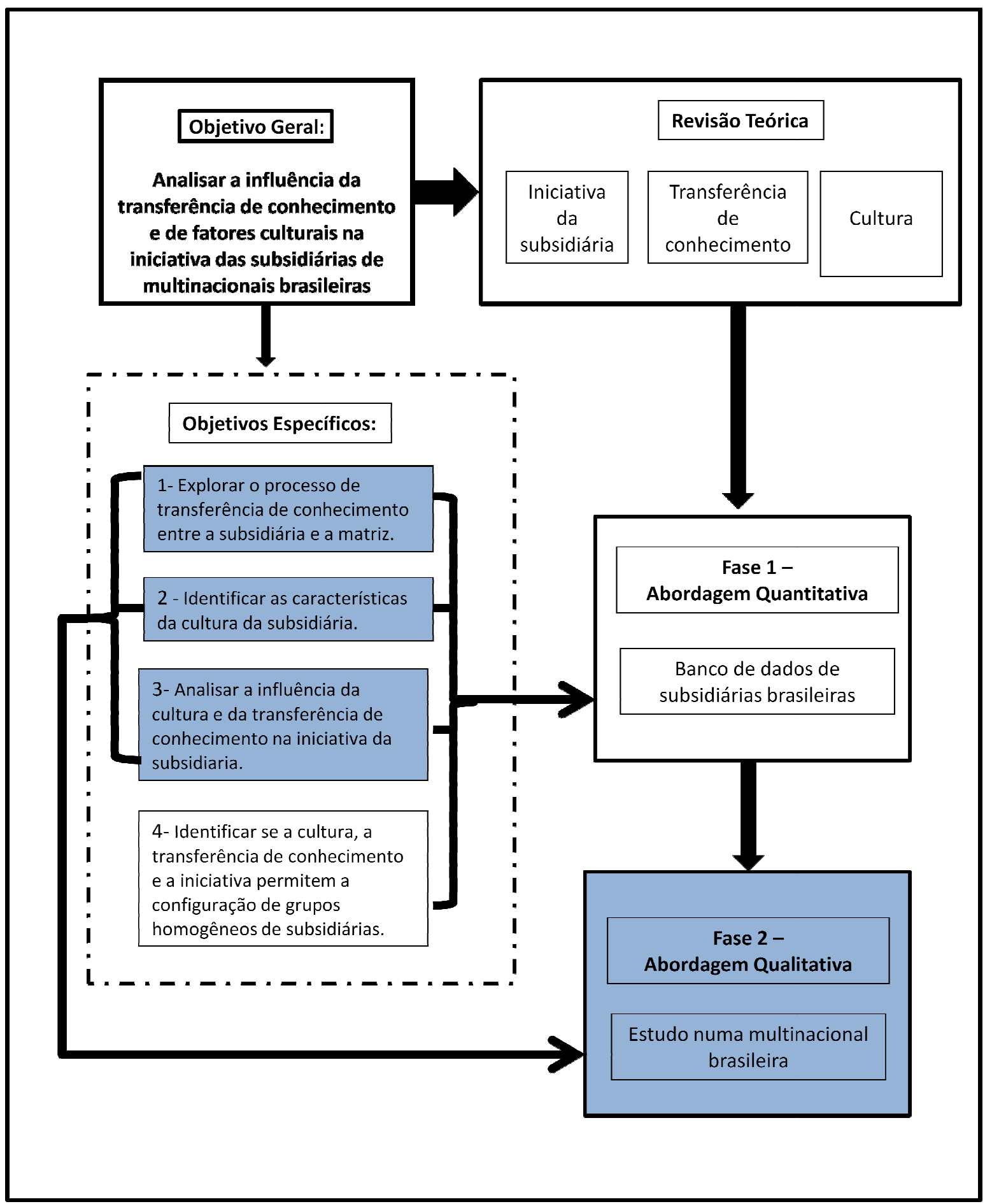

Ilustração 7- Desenho da pesquisa: relação entre os objetivos específicos e a abordagem do estudo

Para melhor compreensão dos procedimentos metodológicos, as duas etapas são apresentadas separadamente na próxima seção, detalhando-se suas particularidades. 


\section{1 - Abordagem quantitativa}

A primeira fase deste estudo caracterizou-se como uma pesquisa quantitativa descritiva que possibilitou a realização de hipóteses inerentes ao modelo delineado e a análise do objetivo central, bem como dos objetivos específicos.

Para Babbie (2005), o estudo descritivo tem a finalidade de descrever situações e eventos. O objetivo primordial é a descrição das características de determinada população ou fenômeno ou, então, o estabelecimento de relações entre variáveis (GIL, 2002).

Quando se decide pela realização de um estudo descritivo pretende-se medir, ou coletar, informações de maneira independente, ou conjunta, sobre conceitos ou sobre as variáveis que explicam determinado conceito (SAMPIERI et al, 2006). Hair (2006, p. 86) aponta que "[...] as hipóteses, derivadas da teoria, normalmente servem para guiar o processo e fornecer uma lista do que precisa ser mensurado."

Os estudos descritivos permitem, assim, integrar as medições ou a informação de cada uma dessas variáveis ou conceitos com a finalidade de explicar como é e como se manifesta o fenômeno de interesse (SAMPIERI et al, 2006). Desta maneira, na primeira etapa, por meio de uma survey e de análises estatísticas, pretendeu-se identificar como os construtos transferência do conhecimento e cultura influenciam a iniciativa das subsidiárias de multinacionais brasileiras.

O método de pesquisa, o instrumento de coleta de dados, a população e amostra do estudo, a coleta e as técnicas de análise dos dados são detalhadas a seguir.

\subsection{1 - Método de coleta de dados}

Para esta primeira parte do estudo, foram utilizados dados coletados no Projeto Temático "Gestão Empresarial para a Internacionalização das Empresas Brasileiras" do Núcleo de Política e Gestão Tecnológica da Universidade de São Paulo, que teve como objetivo compreender as estratégias na gestão de competências para as operações internacionais das multinacionais brasileiras. 
Como método de coleta de dados, utilizou-se a survey que segundo Hair (2006, p. 157) "[...] é usada quando o projeto de pesquisa envolve a coleta de informações de uma grande amostra [...]". Um das vantagens do uso deste método é a postura determinística, ou seja, pelo fato deste tipo de pesquisa permitir elaboração clara e rigorosa de um modelo lógico, "[...] busca explicar as razões para as fontes de eventos, características e correlações observados [...]" (BABBIE, 2005, p. 83).

Geralmente, a utilização de survey visa à descrição; no entanto, vários estudos apresentam como objetivos adicionais realizar asserções explicativas sobre a população em estudo, buscando relacionar duas ou mais variáveis (BABBIE, 2005). Sobre este aspecto, a pesquisa teve intuito descritivo, visto que buscou caracterizar as subsidiárias de multinacionais brasileiras e, explicativo, quando procurou elucidar relações entre as variáveis em estudo.

Dentre as técnicas de coleta de dados existentes, no caso de survey, utiliza-se geralmente questionários, que podem ser aplicados via correio ou por meios eletrônicos, sendo estes mais comuns nos estudos acadêmicos de administração (HAIR et al, 2005).

Cooper e Shindler (2003) evidenciam algumas vantagens e desvantagens do uso de surveys auto-administradas, as quais são apresentadas no Quadro 14.

Quadro 14 - Principais vantagens e desvantagens das surveys auto-administradas

\begin{tabular}{|l|l|}
\hline \multicolumn{1}{|c|}{ Vantagens } & \multicolumn{1}{c|}{ Desvantagens } \\
\hline $\begin{array}{l}\text { - permite contato com respondentes inacessíveis de } \\
\text { outra forma (distância geográfica) } \\
\text { - normalmente, custo baixo }\end{array}$ & \\
- exige poucas pessoas de suporte & - pode haver baixo índice de respostas \\
- percebida como mais anônima & - não é possível a intervenção do entrevistador para \\
- o respondente tem tempo para pensar sobre a & comprovação ou explicação \\
pergunta & - não pode ser longo ou complexo \\
- coleta de dados rápida & \\
- pode usar auxílios visuais & \\
\hline
\end{tabular}

Fonte: Adaptado de COOPER; SCHINDLER, 2003.

Realizou-se uma survey eletrônica, em dois momentos. Primeiramente, contatou-se a matriz da multinacional brasileira e a, partir desta, os contatos foram realizados nas subsidiárias. Os representantes das subsidiárias responderam o questionário via internet, mas houve acompanhamento telefônico para esclarecimentos, quando necessários.

O período de coleta de dados foi de oito meses, com início em dezembro de 2006 e término em junho de 2007. Segundo classificação de Babbie (2005), trata-se de uma survey 
interseccional, pois os dados da amostra colhidos em um certo momento podem ser utilizados tanto para descrever quanto para determinar relações entre variáveis naquela época.

Cabe salientar que apesar de o projeto "Gestão Empresarial para a Internacionalização das Empresas Brasileiras" ter como enfoque a multinacional brasileira sobre os dois contextos: matriz e subsidiária; para o presente estudo a unidade foco da análise da survey foi a subsidiária de multinacional brasileira.

\subsection{2 - População e Amostra}

A população de uma pesquisa corresponde ao agregado de todos os elementos, compartilhando algum conjunto de características comuns, que compõem o universo para o propósito do problema de pesquisa. A amostra consiste na seleção de um grupo de elementos com a intenção de descobrir alguma coisa sobre a população da qual foram extraídos, isto é, um subconjunto da população (MALHOTRA, 2006). Quando se trata de estudo com enfoques quantitativos, Sampieri et al (2006) sugerem como primeiro passo delimitar a população da pesquisa.

Para fins deste estudo, foram considerados os dados decorrentes do Projeto Temático GINEBRA - Gestão Empresarial para a Internacionalização das Empresas Brasileiras, financiado pela FAPESP no período entre 2006 e 2007, coordenado por professores vinculados à Universidade de São Paulo (FLEURY et al, 2007).

Assim, a população desta pesquisa é representada pelas subsidiárias das multinacionais brasileiras com atividades manufatureiras ou de serviço profissional no exterior. Esta escolha excluiu da análise representações comerciais, lojas ou postos de distribuição no exterior. Com base em pesquisas secundárias em diversos mailing nacionais, especialmente o da Editora Análise e em estudos da Unctad e $\mathrm{Cepal}^{3}$, obteve-se um resultado de quarenta e seis (46) multinacionais brasileiras em atividade até o ano de 2006, o que representou uma população de 93 subsidiárias, localizadas em diversos países.

De acordo com Hair et al. (2006), a amostra é delimitada utilizando-se procedimentos nãoprobabilísticos ou probabilísticos. Quando se trata de amostras probabilísticas, todos os

\footnotetext{
${ }^{3}$ Cepal - Comissão Econômica para a América Latina e o Caribe
} 
elementos da população possuem a mesma possibilidade de serem escolhidos. Nas amostras não-probabilísticas, a escolha dos elementos não depende de probabilidade e sim das causas relacionadas com as características da pesquisa (SAMPIERI et al, 2006).

A abordagem utilizada para este estudo é considerada como não-probabilística, por conveniência, porque para a seleção das multinacionais considerou-se aquelas mais disponíveis para participar do estudo e que poderiam oferecer as informações necessárias (HAIR et al, 2006).

Das 46 multinacionais brasileiras elencadas em 2006, somente 29 aceitaram participar da pesquisa, totalizando uma população de 93 subsidiárias em diversos países. Entretanto, deste total, somente 66 participaram efetivamente, o que representa a amostra do presente estudo, explicitada na Tabela 1.

Tabela 1 - Amostra da pesquisa

\begin{tabular}{|c|c|c|c|}
\hline \multirow[t]{2}{*}{ Multinacional } & \multicolumn{3}{|c|}{ Subsidiárias } \\
\hline & $\begin{array}{l}\text { Quantidade na } \\
\text { amostra }\end{array}$ & $\begin{array}{l}\text { Representatividade } \\
\text { na amostra }\end{array}$ & Localização (País) \\
\hline $\begin{array}{l}\text { Andrade } \\
\text { Gutierrez }\end{array}$ & 1 & $1,5 \%$ & Argentina \\
\hline Ambev & 1 & $1,5 \%$ & Equador \\
\hline Artecola & 5 & $7,6 \%$ & Argentina, Colômbia, Chile, México e Peru \\
\hline Atech & 1 & $1,5 \%$ & Estados Unidos \\
\hline CI\&T & 1 & $1,5 \%$ & Estados Unidos \\
\hline $\mathrm{CSN}$ & 2 & $3,0 \%$ & Portugal e Estados Unidos \\
\hline CVRD & 2 & $3,0 \%$ & China e França \\
\hline Embraco & 3 & $4,5 \%$ & China, Itália e Eslováquia \\
\hline Guerra & 1 & $1,5 \%$ & Argentina \\
\hline Ipiranga & 1 & $1,5 \%$ & Chile \\
\hline Marcopolo & 3 & $4,5 \%$ & África do Sul, Portugal e México \\
\hline Metalcorte & 1 & $1,5 \%$ & Argentina \\
\hline Metalfrio & 1 & $1,5 \%$ & Estados Unidos \\
\hline Natura & 5 & $7,6 \%$ & Argentina, Chile, México, Peru e Venezuela \\
\hline Odebrecht & 9 & $13,6 \%$ & $\begin{array}{l}\text { Portugal, Angola, Argentina, Emirados Árabes } \\
\text { Unidos, Estados Unidos (2), México, Peru e } \\
\text { Venezuela }\end{array}$ \\
\hline Oxiteno & 1 & $1,5 \%$ & México \\
\hline Santista & 1 & $1,5 \%$ & Espanha \\
\hline Smar & 1 & $1,5 \%$ & EUA \\
\hline Tigre & 1 & $1,5 \%$ & Colômbia \\
\hline $\mathrm{VM}$ & 1 & $1,5 \%$ & Peru \\
\hline Petrobrás & 11 & $16,7 \%$ & $\begin{array}{l}\text { Argentina (3), Colômbia (2), Uruguai (3), Estados } \\
\text { Unidos, Paraguai e Bolívia }\end{array}$ \\
\hline Sabó & 1 & $1,5 \%$ & Alemanha \\
\hline Embraer & 3 & $4,5 \%$ & China, Estados Unidos e Portugal \\
\hline Weg & 3 & $4,5 \%$ & Portugal, Argentina e China \\
\hline Votorantim & 6 & $7,6 \%$ & Estados Unidos (2), Canadá (3) e Argentina \\
\hline Gerdau & 1 & $1,5 \%$ & Argentina \\
\hline TOTAL & 66 & $100,0 \%$ & \\
\hline
\end{tabular}


Em relação ao setor de atuação, observa-se no Gráfico 1 que há o predomínio de 22 subsidiárias que atuam como montadores de sistemas, seguidas pelas unidades de recursos naturais e, serviços e tecnologia da informação.

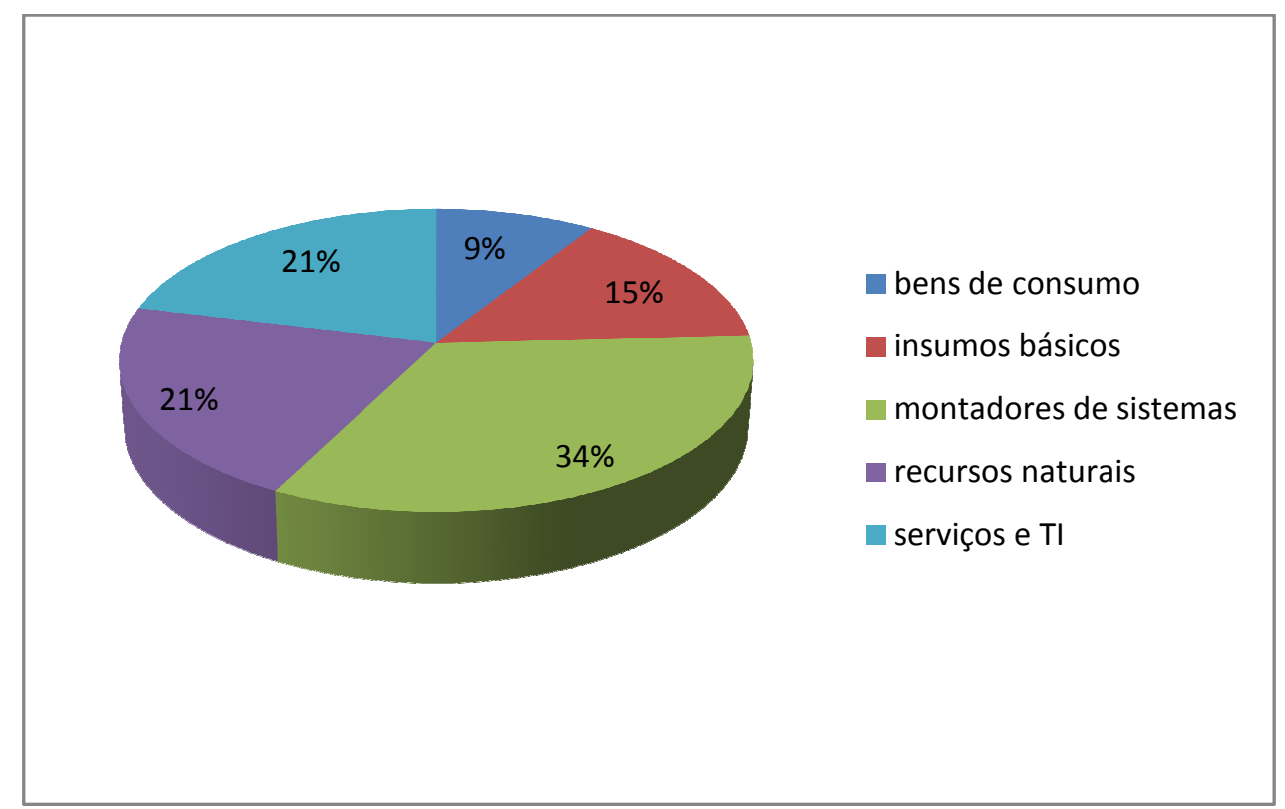

Gráfico 1- Distribuição da amostra em relação aos setores de atuação Fonte: FLEURY et al, 2007.

As subsidiárias das multinacionais brasileiras estão localizadas em 35 pontos da América Latina, seguidas por 14 unidades na América do Norte e 10 na Europa (Gráfico 2). Cabe salientar que os Estados Unidos e a Argentina são os países com maior representatividade das subsidiárias; 11 unidades em cada nação, seguidos pelo México e Portugal, com 5 unidades cada.

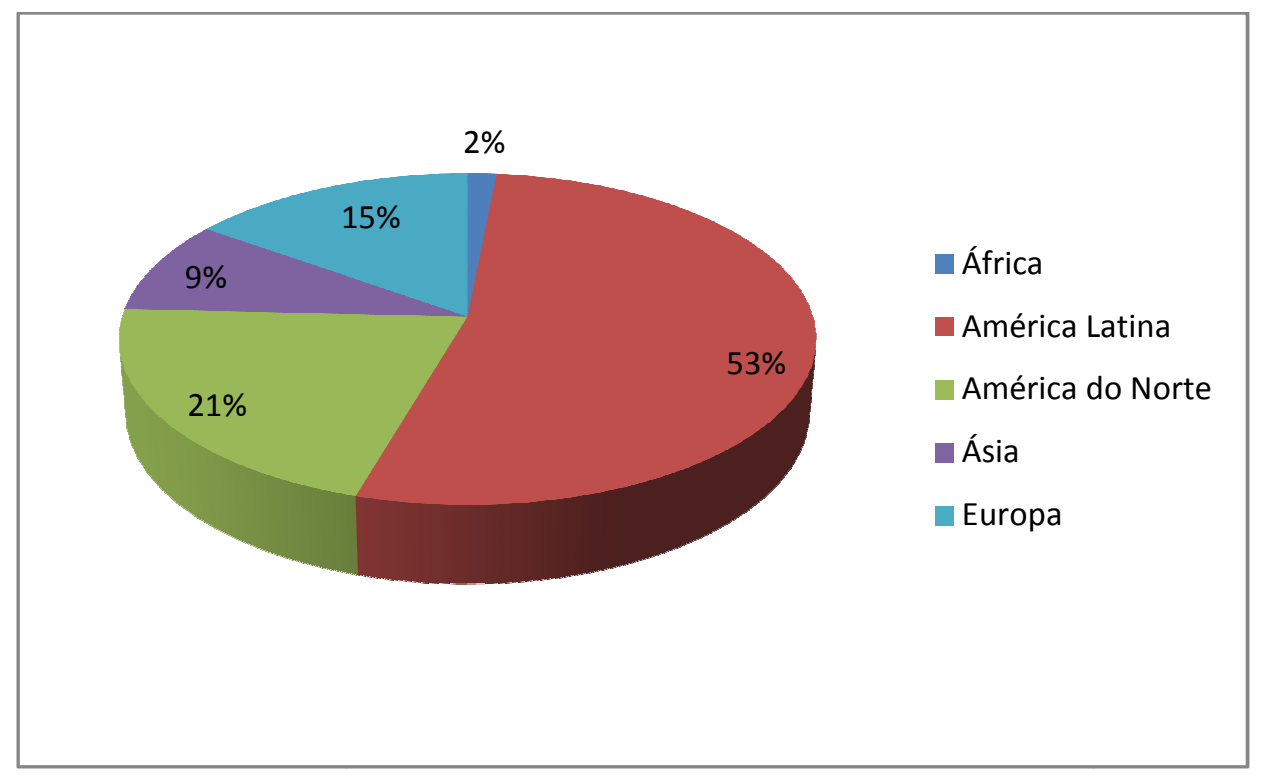

Gráfico 2- Distribuição da amostra em relação ao continente Fonte: FLEURY et al, 2007. 
Em relação a forma de criação das subsidiárias, o Gráfico 3 mostra que as unidades provenientes de aquisição representam $62,1 \%$ da amostra ou 41 unidades, enquanto as oriundas de greenfield, no total de 25 unidades, correspondem a 37,9\%.

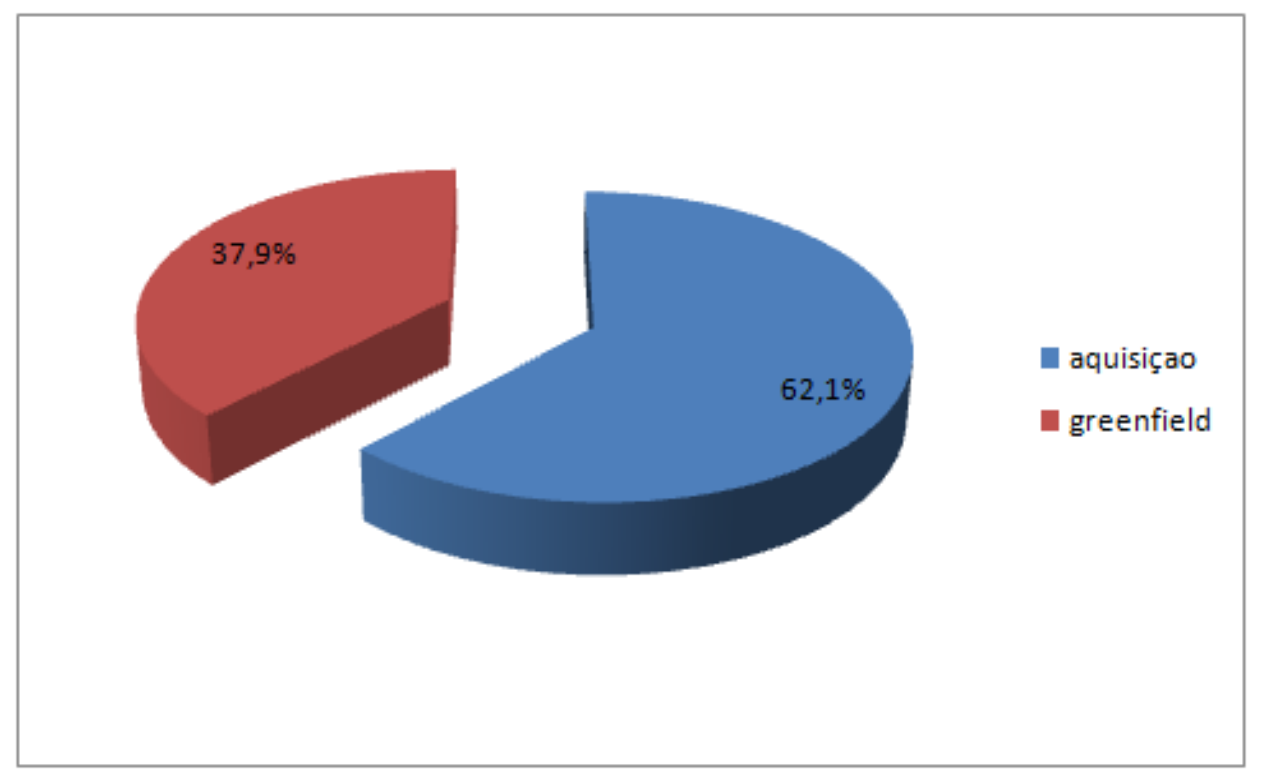

Gráfico 3- Distribuição da amostra em relação a forma de criação da subsidiária Fonte: FLEURY et al, 2007.

\subsection{2 - Instrumento de coleta de dados}

Conforme Hair (2006, p. 159), uma "boa survey exige bons questionários para garantir a precisão dos dados". Assim, optou-se para o referido projeto temático, como instrumento de coleta de dados (ANEXO A), o uso de questionário com perguntas fechadas, cujas questões foram preparadas para avaliar as subsidiárias de empresas multinacionais brasileiras, apresentadas em quatro blocos distintos: características gerais da unidade; relacionamento com a matriz; capacidade, recursos e habilidades da unidade e, macro ambiente em que opera.

Ressalta-se, no entanto, que a maioria das questões apresentava várias afirmativas, para as quais o respondente, representando a subsidiária, deveria aplicar uma escala de Likert, isto é, uma escala de medida com cinco categorias de respostas que variam de "discordo totalmente" a "concordo totalmente" e, que exige dos participantes a indicação do grau de concordância para cada afirmação apresentada (MALHOTRA, 2004). 
A facilidade na elaboração e na aplicação junto aos respondentes são as principais vantagens da utilização da escala de Likert, conforme afirma Malhotra (2004). No entanto, um questionário com este tipo de escala pode exigir mais tempo para ser preenchido quando comparado às outras formas, visto que o respondente precisaria ler e avaliar cada uma das afirmativas.

Hair et al (2006) destacam que esse tipo de escala é originalmente ordinal. Entretanto, para os estudos em administração, pode-se tratá-la como intervalar, o que permite que alguns cálculos e análises estatísticas específicas sejam realizados.

Após a conclusão do instrumento de coleta de dados, realizou-se um pré-teste: professores especialistas na área analisaram as afirmativas e os seus respectivos construtos, identificando possíveis dúvidas ou inadequações. Também foi realizado um pré-teste com uma multinacional e uma subsidiária.

Para atender o objetivo desta pesquisa, considerou-se para análise as questões referentes à transferência de conhecimento, iniciativa e cultura do questionário original (ANEXO A). As questões relacionadas a estes construtos são exploradas a seguir.

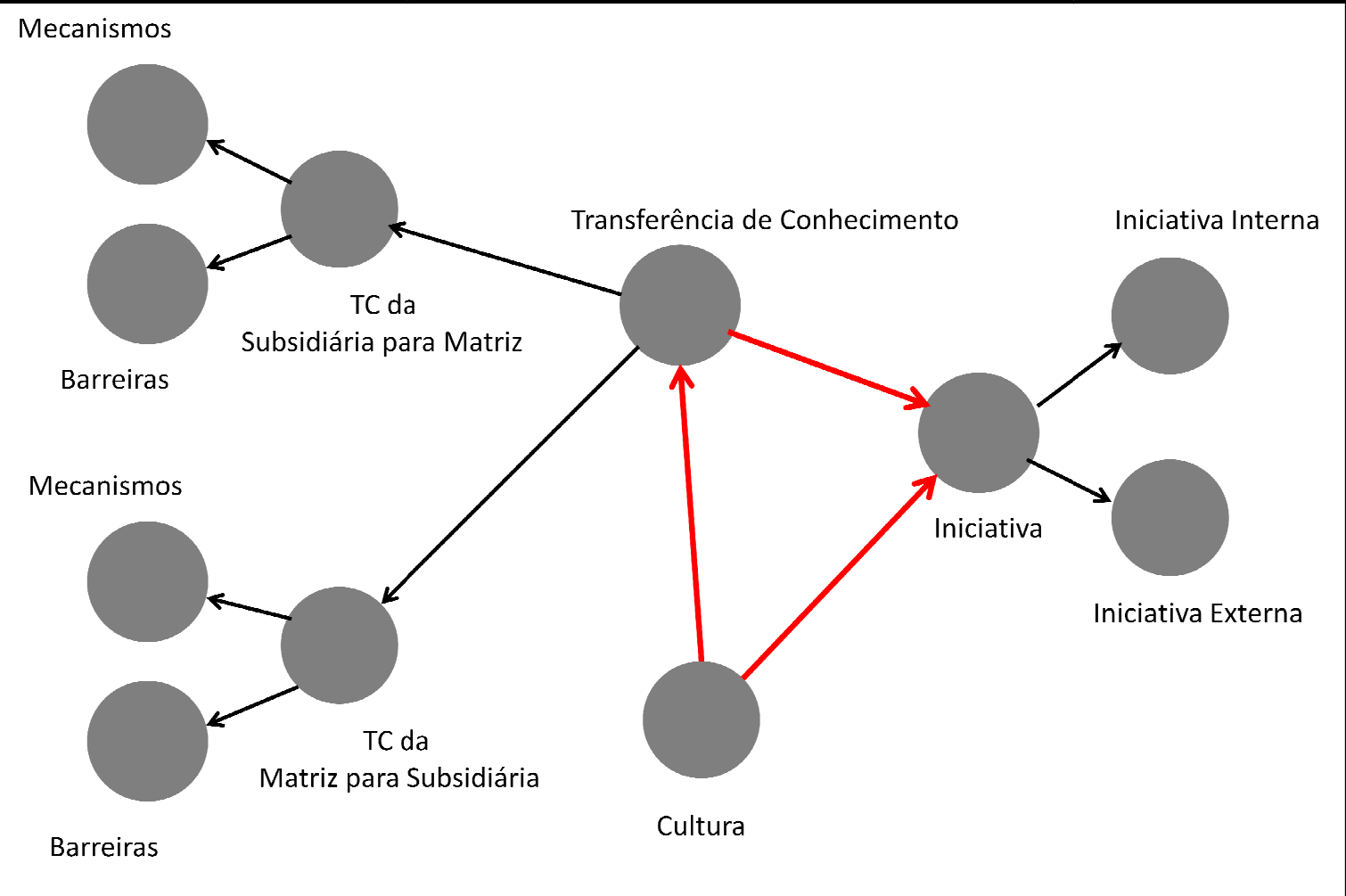

Ilustração 8 - Modelo da pesquisa 


\section{a) Transferência de Conhecimento}

No modelo deste estudo, o construto transferência de conhecimento é reflexivo (variável latente) de terceira ordem. Conforme Hair et al. (2005, p. 467), trata-se de "um conceito que pode ser definido em termos teóricos e que não pode ser medido diretamente, mas pode ser medido por meio de indicadores". Desta maneira, a transferência de conhecimento é medida por meio de outros dois construtos: transferência de conhecimento da subsidiária para matriz e outras unidades e, a transferência de conhecimento da matriz para a subsidiária.

Todavia, esses construtos - transferência de conhecimento da subsidiária para matriz e a transferência de conhecimento da matriz para a subsidiária - são igualmente construtos reflexivos de segunda ordem, os quais também não podem ser apurados diretamente. Por isso, não há questões específicas no questionário.

Assim, cada um destes processos é o resultado dos construtos de primeira ordem: mecanismos de transferência utilizados entre as unidades e das barreiras existentes.

Para identificar os mecanismos de transferência de conhecimento, foram propostas duas questões com dez afirmativas cada (Quadro 15), tendo como parâmetro os estudos de Gupta e Govindarajan (2000) que evidenciam as principais práticas existentes: o fluxo de pessoas, as regras, os procedimentos, os relatórios e manuais, a interação eletrônica; as equipes internacionais e os encontros internacionais para um projeto específico, dentre outras.

Em relação aos mecanismos de transferência de conhecimento da matriz para a subsidiária, o propósito da questão foi identificar as ações utilizadas a fim de disseminar ou implementar uma atividade desenvolvida pela matriz; enquanto nas questões relacionadas aos mecanismos de transferência de conhecimento da subsidiária para a matriz, buscou-se averiguar como ocorre o fluxo de conhecimento das unidades para a matriz.

É importante ressaltar que o conteúdo das duas questões é o mesmo, mudando-se somente o emissor e o receptor das atividades, práticas e conhecimentos e, que os dados são oriundos da pesquisa somente com as subsidiárias. Logo, o processo de transferência de conhecimento da matriz para a subsidiária é resultado da percepção da unidade.

Para identificar as barreiras no processo de transferência de conhecimento, foram elaboradas novamente duas questões (Quadro 15). Segundo Gupta e Govindarajan (2000), os 
principais fatores que podem contribuir ou dificultar a transferência de conhecimento entre a matriz e a subsidiária são: valor do estoque de conhecimento da unidade como vantagem relativa para as demais, disposição motivacional da unidade fonte para compartilhar conhecimentos, existência e eficiência dos canais de transmissão, disposição motivacional da unidade receptiva para reconhecer os conhecimentos gerados pela outra unidade e capacidade de absorção da unidade receptiva.

A partir desses conceitos, elaborou-se oito afirmativas que pudessem evidenciar as possíveis barreiras estruturais ou comportamentais existentes na transferência de conhecimento entre a matriz e as unidades. Cabe salientar que utilizou-se as mesmas afirmativas tanto para identificar as barreiras da matriz para a subsidiária, quanto no sentido oposto. 
Quadro 15 - Construtos e variáveis relacionadas à transferência de conhecimento

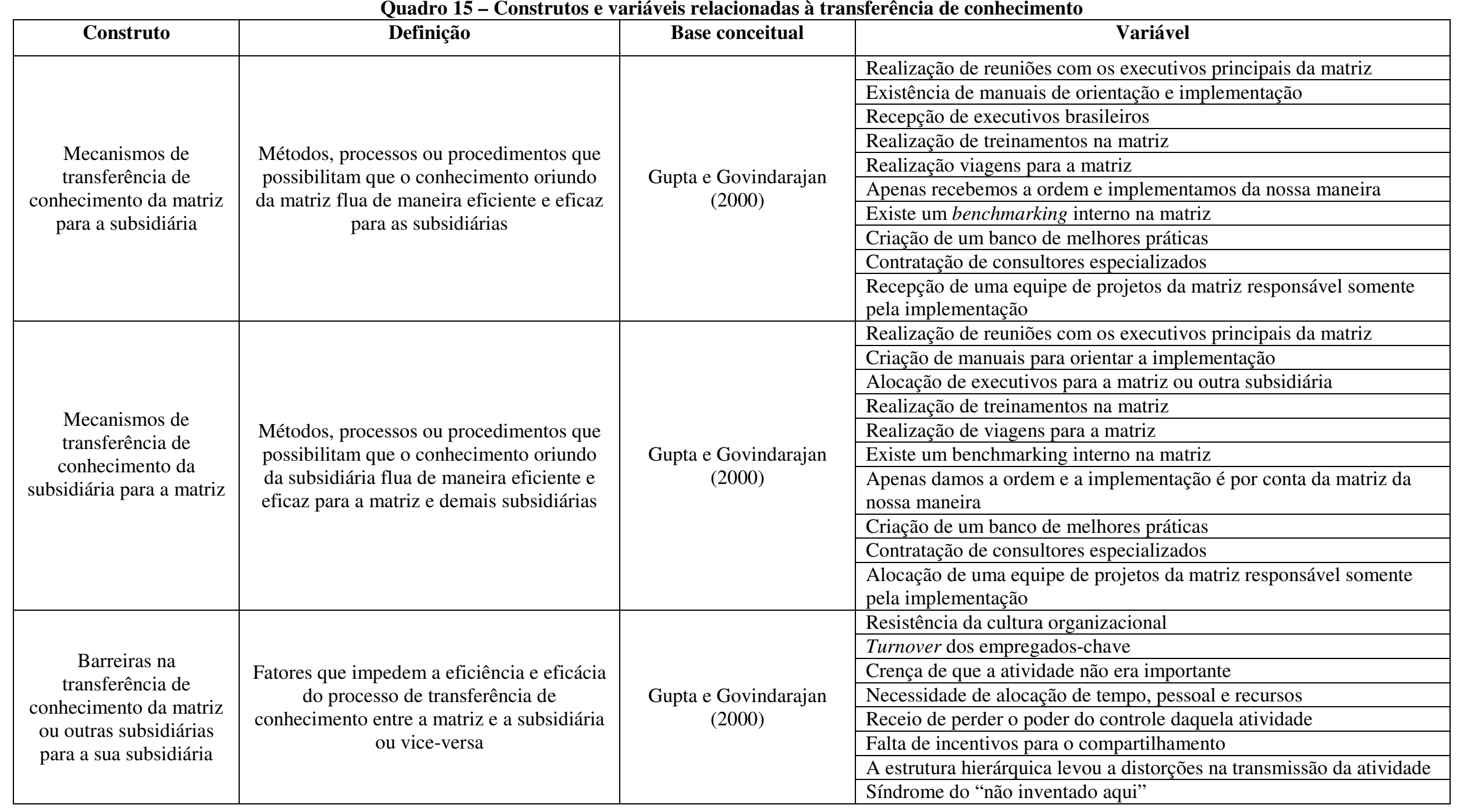




\section{b) Cultura}

A questão relacionada à cultura local da subsidiária foi elaborada com base nos instrumentos originais validados por Hofstede (2001). No entanto, para que a pesquisa não se tornasse exaustiva para o respondente, foram selecionadas algumas afirmativas que, no conjunto, representassem as quatro principais dimensões daquele estudo: distância do poder, individualismo, masculinidade e controle de incertezas, conforme apresentado no Quadro 16, a seguir.

Salienta-se que, mesmo reconhecendo as quatro dimensões separadamente, para o modelo proposto de estudo, a cultura foi analisada como um construto de primeira ordem, visto que para ter uma confiabilidade aceitável é necessário apresentar de cinco a sete indicadores (HAIR, 2005). 
Quadro 16 - Construto e variáveis relacionadas à cultura

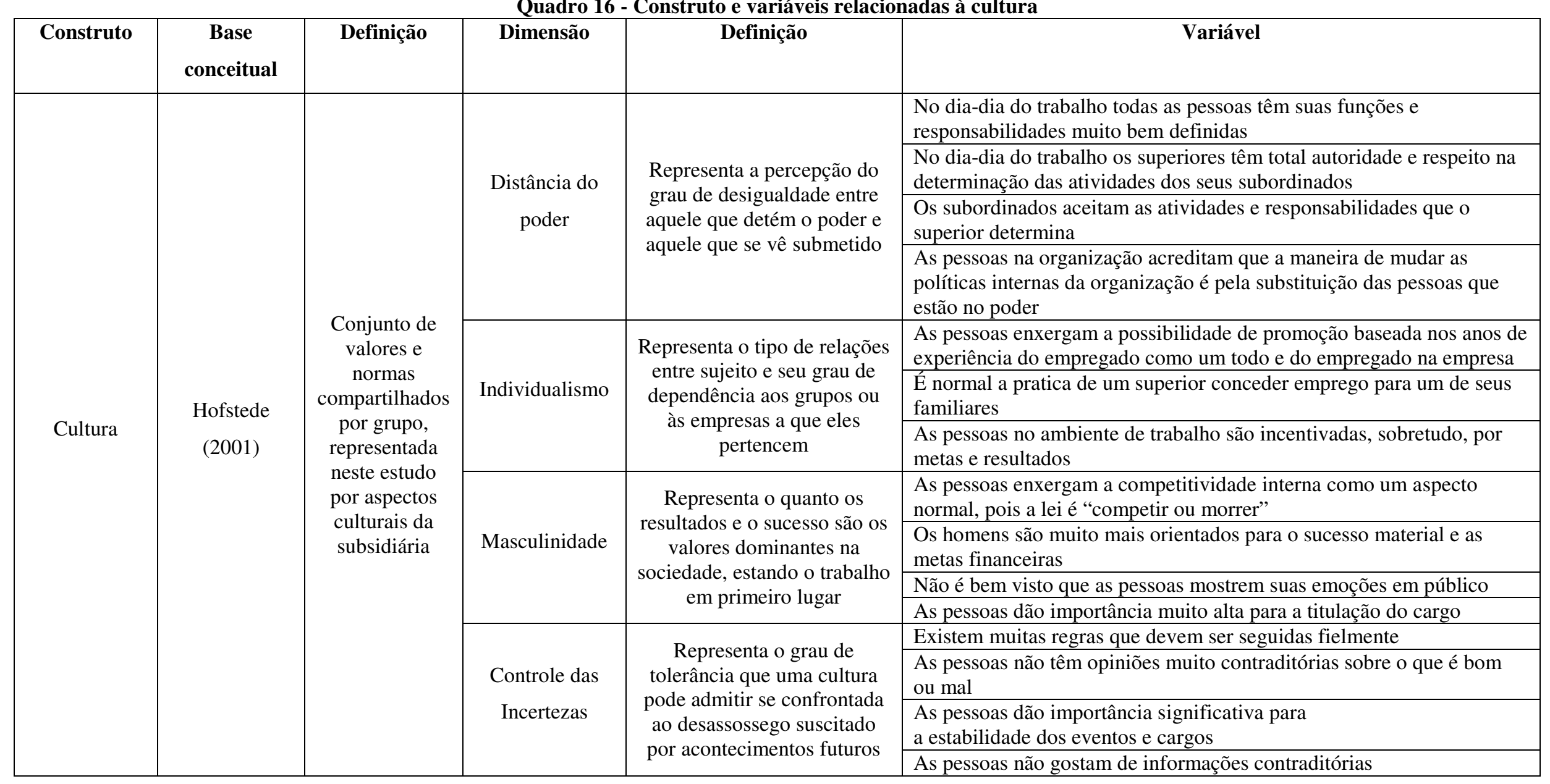


c) Iniciativa

Conforme mencionado anteriormente, a iniciativa da subsidiária é um construto de segunda ordem, apresentando as duas abordagens denominadas construtos de primeira ordem: iniciativas internas e iniciativas externas.

Para a elaboração da questão relativa às iniciativas internas (Quadro 17) foram considerados relevantes os conceitos de Birkinshaw (1999), e o uso de afirmativas validadas em estudos anteriores, buscou-se identificar com que extensão as atividades relacionadas ocorreram na subsidiária nos últimos anos.

Os conceitos de redes de Andersson e Forsgren (2002) contribuíram para a elaboração da questão e das afirmativas sobre a iniciativa externa (Quadro 17). O propósito principal foi identificar como as relações com organizações específicas têm contribuído para o desenvolvimento do negócio da subsidiária. 
Quadro 17 - Construto e variáveis relacionadas à iniciativa

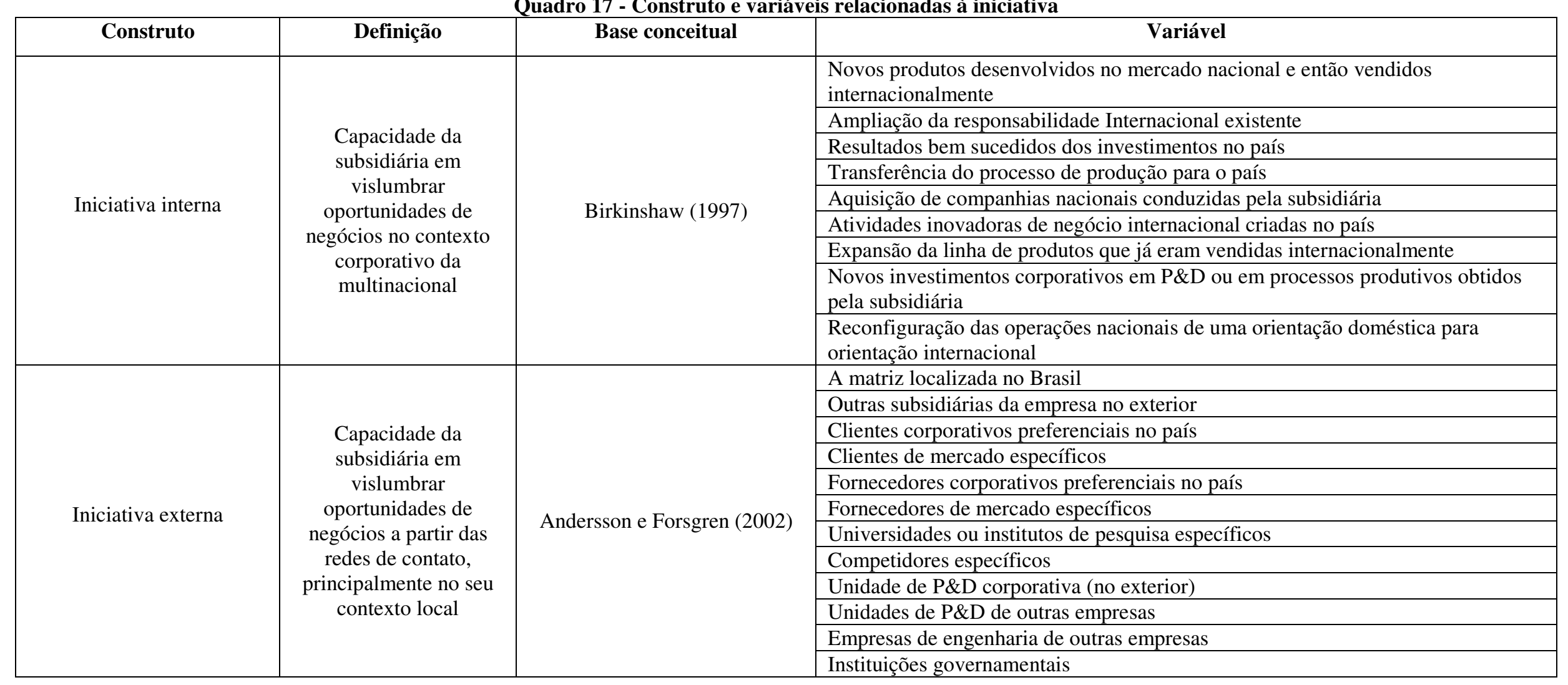




\subsection{4 - Análise dos dados}

Antes da análise dos dados, alguns cuidados envolvendo toda a amostra foram tomados, como os poucos casos de respostas não dadas (missing), os quais foram substituídos pelo valor da moda de cada variável.

A partir disso, as técnicas de análise estatística, que permitem obter, de conjuntos complexos, representações simples e a verificação de relações entre as variáveis (MARCONI; LAKATOS, 2001), foram aplicadas visando atingir cada objetivo específico do estudo, conforme explicitado no Quadro 18 e detalhado a seguir.

Para contemplar esses objetivos, foram utilizados alguns softwares, tais como o Excel, para elaboração de gráficos, estatísticas descritivas e técnicas estatísticas simples; SPSS (Statistical Package for the Social Sciences) para análises estatísticas multivariadas e, o SmartPLS para a modelagem de equações estruturais, bem como o software GPower 3, para verificar o efeito do tamanho da amostra, como é melhor explicitado nas próximas seções. 
Quadro 18 - Objetivos específicos e técnicas de análise estatística

\begin{tabular}{|c|c|c|c|}
\hline Objetivos Específicos & $\begin{array}{c}\text { Técnica de Análise } \\
\text { Estatística }\end{array}$ & Variáveis envolvidas & Resultados Esperados e Obtidos \\
\hline $\begin{array}{l}\text { 1- Explorar o processo de } \\
\text { transferência de conhecimento entre } \\
\text { a subsidiária e a matriz }\end{array}$ & Análise Estatística Descritiva & $\begin{array}{l}\text { - Transferência de conhecimento da matriz } \\
\text { para subsidiária: K1 a K10 (mecanismos) e BK } \\
1 \text { a BK } 8 \text { (barreiras) } \\
\text { - Transferência de conhecimento da subsidiária } \\
\text { para matriz: KS1 a KS } 10 \text { (mecanismos) e } \\
\text { BKS 1 a BKS } 8 \text { (barreiras) }\end{array}$ & $\begin{array}{l}\text { A técnica possibilitou a descrição da amostra em } \\
\text { relação ao processo de transferência de } \\
\text { conhecimento, evidenciando as semelhanças e } \\
\text { diferenças entre as unidades provenientes de } \\
\text { aquisição e greenfield }\end{array}$ \\
\hline $\begin{array}{l}2 \text { - Identificar características da } \\
\text { cultura da subsidiária }\end{array}$ & Análise Estatística Descritiva & - Dimensões da Cultura: HOF 1 ao HOF 15 & $\begin{array}{l}\text { A técnica possibilitou a comparação dos grupos } \\
\text { formados em relação às dimensões da cultura, } \\
\text { evidenciando semelhanças e diferenças com a } \\
\text { brasileira }\end{array}$ \\
\hline $\begin{array}{l}\text { 4- Identificar se a cultura, a } \\
\text { transferência de conhecimento e a } \\
\text { iniciativa permitem a configuração } \\
\text { de grupos homogêneos de } \\
\text { subsidiárias }\end{array}$ & Análise de Conglomerados & $\begin{array}{l}\text { - Escores, oriundos da modelagem de equações } \\
\text { estruturais, dos construtos: transferência de } \\
\text { conhecimento da matriz para subsidiária, } \\
\text { transferência de conhecimento da subsidiária } \\
\text { para a matriz, cultura, iniciativa interna e } \\
\text { iniciativa externa }\end{array}$ & $\begin{array}{l}\text { A técnica permitiu o agrupamento de subsidiárias } \\
\text { por dados semelhantes, reduzindo a amostra inicial } \\
\text { de } 66 \text { unidades para } 3 \text { grupos com resultados } \\
\text { semelhantes em relação aos construtos }\end{array}$ \\
\hline
\end{tabular}




\subsubsection{1 - Análise descritiva}

Para atingir os objetivos específicos de explorar o processo de transferência de conhecimento entre a subsidiária e a matriz e de identificar características da cultura da subsidiária, utilizou-se das técnicas de estatística descritiva.

A fim de explorar a transferência de conhecimento entre a subsidiária e a matriz, optouse por comparar tal processo entre as unidades provenientes de greenfield e de aquisição, sendo que para cada afirmativa, numa escala Likert, o respondente da subsidiária deveria assinalar aquela que melhor representasse a situação encontrada naquele momento. Entretanto, para análise dos dados, foram consideradas as frequências das respostas "concordo" (4) e "concordo plenamente" (5), visto que o objetivo principal foi o de analisar os mecanismos de transferência de conhecimento mais utilizados entre a matriz e a subsidiária, bem como as barreiras existentes no processo.

Com o intuito de identificar características da cultura da subsidiária, inicialmente, agrupou-se as 66 subsidiárias da amostra em três conglomerados, sendo que para cada afirmativa sobre os aspectos culturais, o respondente tinha cinco opções, entre (1) "discordo plenamente" até (5) "concordo plenamente". No entanto, para melhor análise dos resultados em relação à cultura, reduziu-se as cinco possibilidades de respostas obtidas a apenas três: "concordo" (agrupando as respostas concordo plenamente e concordo na maioria das vezes), "discordo" (agrupando as respostas discordo plenamente e discordo na maioria das vezes) e “às vezes concordo e às vezes discordo".

Mediante aos cálculos estatísticos, para cada afirmativa, buscou-se comparar os percentuais das respostas positivas, negativas e neutras dentre os conglomerados estabelecidos.

\subsubsection{2 - Modelagem de equações estruturais}

Para contemplar o objetivo específico de analisar a influência da cultura e da transferência de conhecimento na iniciativa da subsidiaria, utilizou-se a modelagem de equações estruturais a fim de identificar as relações existentes entre as variáveis: cultura, 
transferência de conhecimento e iniciativa obtidas junto às subsidiárias de multinacionais brasileiras (Ilustração 9).

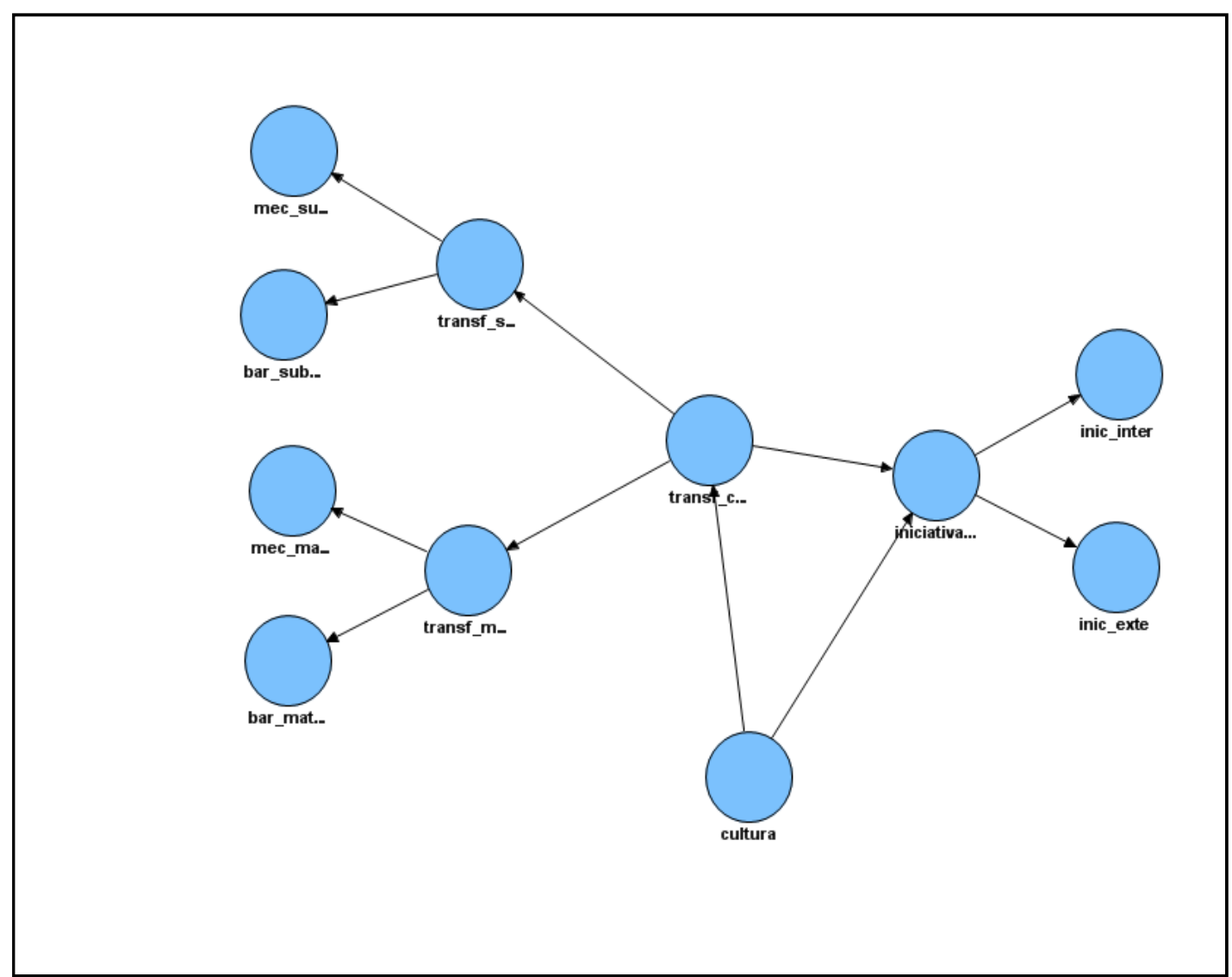

Ilustração 9 - Modelo proposto na modelagem de equações estruturais Fonte: Software SmartPLS

Essa técnica, diferentemente de outras técnicas de regressão, permite representar múltiplas relações simultaneamente e com especificação da direção causal. De acordo com Klem (1995 apud FARIAS e SANTOS, 2000), a modelagem de equações estruturais (MEE) pode ser vista como a extensão da regressão múltipla, sendo que na aplicação desta, o pesquisador está interessado em prever uma única variável dependente, enquanto na MEE há mais de uma variável dependente. Se na regressão múltipla X influencia $Y$, na MEE X influencia Y e Y influencia Z.

Além disso, essa técnica combina elementos de análise fatorial (representando fatores ou construtos não diretamente observados), o que permite estimar uma série de relações de dependência simultaneamente e explicar erros de mensuração no processo de estimação (HAIR et al 2005). 
Conforme Zwicker et al (2008), a MEE deve ter início em um modelo conceitual que especifique as relações entre um conjunto de variáveis (indicadores), o que permitirá fazer estimativas das influências que exercem todas estas variáveis sobre outras variáveis representadas em um esquema teórico. Os construtos são frequentemente tratados como variáveis latentes (VL), em virtude de não poderem ser medidos diretamente, mas por uma ou mais variáveis manifestas ou indicadores (NIÑO, 2009).

Kline (1998 apud SOUZA, 2004) considera que a MEE é uma técnica a priori, isto é, uma série de definições deve ser estabelecida previamente pelo pesquisador, tais como: quais variáveis influenciam outras e quais são as direções de causalidade dessas relações. Estas especificações refletem as hipóteses do pesquisador e, em seu conjunto, compõem o modelo a ser avaliado, ou seja, o modelo de mensuração e o modelo estrutural.

A MEE apresenta dois submodelos: mensuração e estrutural. Segundo Hair et al (2005), o modelo de mensuração especifica os indicadores (variáveis observáveis) para cada construto e avalia a confiabilidade de cada um destes (variável latente) para estimar as relações causais. Este modelo é semelhante em forma à análise fatorial, mas o pesquisador deve especificar quais variáveis são indicadores para cada construto.

A avaliação do modelo de mensuração é feita para demonstrar um nível satisfatório de validade e confiabilidade e os parâmetros utilizados para cumprir com esta condição são: validade de conteúdo, validade convergente, confiabilidade composta e validade discriminante.

A validade de conteúdo é definida por Hair et al (2006) como sendo a avaliação do grau de correspondência entre os itens selecionados para constituir uma escala múltipla e sua definição conceitual. É uma avaliação subjetiva (MALHOTRA, 2006) na qual o próprio pesquisador e especialistas no assunto examinam se os itens da escala abrangem todo o domínio do construto que está sendo medido. Ressalta-se que o questionário usado não precisou ser validado, visto que esta etapa já fora realizada no momento de sua elaboração, conforme Fleury et al (2007).

A validade convergente avalia o grau em que duas medidas do mesmo conceito estão correlacionadas. É esperado alto valor de correlação (HAIR et al, 2006). Para este estudo, a validade convergente foi avaliada com base em três critérios: carga fatorial superior a 0,7 ; 
carga fatorial significante; e variância média extraída superior a 0,5 (FORNELL; LARCKER, 1981).

A partir disto, deve-se verificar a confiabilidade dos construtos, ou seja, a coerência dos dados resultantes da pesquisa. No caso de instrumentos de coleta de dados com escalas de itens múltiplos, para que seja confiável, os escores para as afirmativas individuais (indicadores, variáveis) que compreendem a escala devem ser correlacionados, por que quanto mais fortes as correlações, maior a confiabilidade da escala (HAIR et al, 2005).

Neste estudo, a confiabilidade foi avaliada pela confiabilidade composta e pelo alfa de Cronbach, uma medida de consistência interna baseada na correlação média entre as variáveis de um construto. A medida varia entre 0 e 1, sendo que Hair et al (2005) aconselham o valor 0,6 como o limite inferior aceito em pesquisas exploratórias. Uma propriedade importante deste coeficiente, destacado por Malhotra (2004), é que seu valor tende a aumentar com o número de itens na escala.

Hair et al (2005, p. 489) alertam que “[...] confiabilidade não garante validade. A validade é o grau em que os indicadores medem com precisão aquilo que eles devem efetivamente medir $[\ldots] "$.

A validade discriminante é fundamental para averiguar se um construto qualquer difere de outros construtos do estudo. Obtém-se esta análise por meio das correlações entre todos os indicadores e os construtos do modelo. Se a correlação for baixa entre os indicadores e demais construtos, pode-se concluir que o construto possui validade discriminante.

Diferentemente do modelo de mensuração, o modelo estrutural representa o conjunto de uma ou mais relações de dependência conectando os construtos, sendo útil para especificar as conexões entre os construtos (HAIR et al, 2005).

Para estimar os modelos de mensuração e estrutural, a MEE apresenta alguns métodos, sendo os mais conhecidos, o baseado em covariâncias (MEEBC) e, o Partial Least Squares (MEEPLS), que avalia o modelo por partes. O método de estimação utilizado foi o PLS-PM Partial Least Squares $\boldsymbol{P}$ ath Modeling em função da sua maior simplicidade de aplicação e flexibilidade quanto à distribuição dos dados. Zwicker et al (2008) apresentaram uma série de critérios para a escolha entre os métodos MEEPLS e MEEBC (Quadro 19): 


\begin{tabular}{|l|l|l|}
\hline \multicolumn{2}{l}{ Quadro 19 - Diferenças entre a MEEPS e MEEBC } \\
\hline Critério & \multicolumn{1}{|c|}{ MEEPLS } & \multicolumn{1}{c|}{ MEEBC } \\
\hline Objetivo & Predição & $\begin{array}{l}\text { Explicação: modelo causal e testes de } \\
\text { teorias }\end{array}$ \\
\hline Precisão & $\begin{array}{l}\text { Consistente conforme o tamanho da } \\
\text { amostra e a quantidade de indicadores }\end{array}$ & Ótimo para grandes amostras \\
\hline Modelo de mensuração & $\begin{array}{l}\text { Pode haver indicadores formativos e } \\
\text { reflexivos }\end{array}$ & Apenas indicadores reflexivos \\
\hline $\begin{array}{l}\text { Requisitos quanto à } \\
\text { teoria }\end{array}$ & $\begin{array}{l}\text { Mais flexível, contexto mais } \\
\text { exploratório }\end{array}$ & Fortemente dependente da teoria \\
\hline Tamanho da amostra & $\begin{array}{l}\text { Análise do poder estatístico com a } \\
\text { porção do modelo que possui o maior } \\
\text { número de preditores ou 10 vezes o } \\
\text { maior número de preditores } \\
\text { (indicadores formativos ou setas } \\
\text { estruturais chegando na VL, o que for } \\
\text { maior). Sendo o mínimo recomendado } \\
\text { de } 30 \text { a 100 casos }\end{array}$ & $\begin{array}{l}\text { Idealmente baseado na análise do poder } \\
\text { datatístico, sendo o mínimo recomendendo } 200 \text { casos }\end{array}$ \\
\hline Complexidade & $\begin{array}{l}\text { Capaz de lidar com alta complexidade } \\
\text { (100 construtos e 1000 indicadores) }\end{array}$ & $\begin{array}{l}\text { Complexidade de média a moderada } \\
\text { (menos de 100 indicadores) }\end{array}$ \\
\hline
\end{tabular}

Fonte: Adaptado de ZWICKER et al, 2008.

Dentre as diferenças entre o MEEPLS e o MEEBC, destaca-se, no contexto desta pesquisa, o fato de o primeiro ser mais adequado quando o número de dados para a análise é limitado, contrapondo-se ao segundo, que permite a estimação somente com um número expressivo de dados.

Para o processamento dos dados, utilizou-se o software SmartPLS 2.0 M3. O modelo estrutural foi estimado por meio da técnica de bootstrapping, que Hair et al (2006, p. 466) apontam como sendo a "reamostragem na qual os dados originais são repetidamente amostrados com substituição para estimação do modelo [...]”.

A MEEPLS não possui uma medida global de ajuste do modelo aos dados empíricos, evidenciados por Zwicker et al (2008). Desta maneira, indicam três medidas de verificação da qualidade do modelo: variância média explicada (AVE), $\mathrm{R}^{2}$ e Goodeness of fit measure (GOF).

A AVE demonstra a adequação ao modelo de mensuração, enquanto que o $\mathrm{R}^{2}$, a adequação ao modelo estrutural. Já a medida GOF avalia se o modelo tem ou não ajustes aos dados empíricos. Tenenhaus et al (2005 apud ZWICKER et al, 2008) propuseram este índice de adequação do modelo, cujo valor é a média geométrica entre o $\mathrm{R}^{2}$ médio e a AVE média ponderada pela quantidade de indicadores. 
Outro aspecto importante diz respeito ao tamanho da amostra, a partir da análise do poder do teste, cuja importância é enfatizada nos textos sobre estatística, em ciências sociais (FAUL et al, 2009).

O poder do teste estatístico é a probabilidade de rejeitar a hipótese nula, dada que a mesma é falsa. A estatística do poder depende de três classes de parâmetros: o nível de significância (probabilidade do erro tipo I - alfa), o tamanho da amostra utilizada e o tamanho do efeito.

Dependendo dos recursos disponíveis, da etapa do processo de pesquisa e da questão de pesquisa, cinco diferentes tipos de análise do poder podem ser utilizados: análise do poder $a$ priori, análise do poder a posterior, análise do poder ajustado, análise de sensibilidade e análise de critério (FAUL et al, 2009). Para este estudo, utilizou-se a análise de sensibilidade, ou seja, visto que a amostra era conhecida e limitada (66 subsidiárias), verificou-se se o tamanho do efeito detectado foi de todo realista.

Para isso, utilizou-se o software GPower 3, que segundo Faul et al (2007) envolve quatro etapas: seleção do teste estatístico apropriado para o problema, escolha de um dos cinco tipos de análise de poder, indicação dos parâmetros de entradas necessários para analise e obtenção dos resultados.

A regressão linear múltipla, que testa o efeito total (sendo a hipótese do teste que o valor do $\mathrm{R}^{2}$ para a população é diferente de zero) e testa a hipótese de que a adição de mais preditores aumenta o valor do $\mathrm{R}^{2}$, foi utilizada nesta pesquisa.

Segundo o critério de Cohen (1988 apud FAUL et al, 2007), o efeito do tamanho de 0,02; 0,15 e 0,35 são considerados pequeno, médio e grande, respectivamente. É possível mensurar um $\mathrm{R}^{2}$ de referência a partir do valor do efeito do tamanho, que para ser calculado, utilizou-se alfa de 5\%, poder de $80 \%$, amostra de 66 unidades e 2 preditores. Como saída, obteve-se 0,1531 para o efeito do tamanho, conforme demonstrado na Tabela 2. 
Tabela 2 - Análise de sensibilidade da amostra

\begin{tabular}{lll}
\hline F tests - Linear multiple regression: Fixed model, $\mathrm{R}^{2}$ deviation from \\
Analysis: & Sensitivity: Compute required effect size \\
Input: & $\alpha$ err prob & $=0.05$ \\
& Power ( $1-\beta$ err prob) & $=0.8$ \\
& Total sample size & $=66$ \\
& Number of predictors & $=2$ \\
Output: & Noncentrality parameter $\lambda$ & $=10.1079146$ \\
& Critical F & $=3.1428085$ \\
& Numerator $\mathrm{df}$ & $=2$ \\
& Denominator $\mathrm{df}$ & $=63$ \\
& Effect size $\mathrm{f}^{2}$ & $=0.1531502$
\end{tabular}

A partir do valor do efeito do tamanho foi possível calcular o $\mathrm{R}^{2}$, neste caso, $13,3 \%$. Desta maneira, ao término da análise da modelagem de equações estruturais, se o $\mathrm{R}^{2}$ encontrado fosse maior do que 13,3\%, o tamanho da amostra seria detectado como significante.

\subsubsection{3 - Análise de conglomerados}

Hair et al (2006, pg. 400) definem a análise de conglomerados (ou agrupamentos) como uma técnica multivariada de interdependência, visto que procura combinar "objetos que tenham alta homogeneidade interna (dentro do conglomerado) bem como alta heterogeneidade externa (entre conglomerados)".

A técnica de conglomerados foi utilizada em dois momentos no estudo, inicialmente, como parte do processo para contemplar o objetivo de identificar características da cultura da subsidiária, quando procurou-se organizar as subsidiárias em grupos a partir de dados do estudo de Hofstede (2001) para as dimensões da cultura (distância do poder, individualismo, masculinidade e controle de incerteza) dos países sedes das subsidiárias.

Posteriormente, utilizou-se a referida técnica visando atingir o objetivo de investigar se a cultura, a transferência de conhecimento e a iniciativa permitem a configuração de grupos homogêneos de subsidiárias, a partir dos escores dos construtos transferência de conhecimento (matriz para subsidiária e desta para matriz), cultura e iniciativa (interna e externa) do modelo de equações estruturais. 
A análise de agrupamentos tem o objetivo principal de definir a estrutura dos dados colocando as observações mais parecidas em grupos. Para tanto, Hair et al (2006) orientam que deve-se definir inicialmente a medida de distância, o método de aglomeração e o número de grupos pretendidos.

Existem duas técnicas de análise de conglomerados: análise de conglomerados hierárquicos (Hierarchical Cluster), quando o pesquisador não sabe a priori o número de grupos pretendidos e deseja encontrar a melhor resposta; e a análise de conglomerados k-médias $(k$ means), quando se conhece a priori o número de grupos pretendidos. Este pode ser utilizado para refinar os resultados do modelo hierárquico e/ou para grandes volumes de dados.

Para medir a similaridade é preciso um método de comparação simultânea de observações sobre as variáveis de agrupamento, sendo a distância quadrática euclidiana, a correlação de Pearson, o Chebychev e Blocos os principais tipos de medidas de distância. Dentre estes métodos, o primeiro é o mais utilizado, sendo aplicado neste estudo.

Com relação ao método de aglomeração, o critério para colocar objetos similares dentro de grupos conforme as possibilidades existentes no programa SPSS, deve ser o de sempre maximizar as diferenças entre os grupos em confronto com a variação dentro dos mesmos (POHLMANN, 2007). Dentre os algoritmos, destaca-se a variação entre os grupos (betweencluster variation) que tende a combiná-los com menores variações internas.

Para este estudo, nos dois momentos de uso da técnica, analisou-se inicialmente os conglomerados hierárquicos, sendo a distância quadrática euclidiana a medida de distancia e between group, como o método de aglomeração. Para refinar os resultados obtidos, utilizou-se a análise de conglomerados k-médias para 3 conglomerados.

A técnica análise da variância foi utilizada para reforçar o resultado dos conglomerados. A ANOVA é um teste de médias para duas ou mais populações, no caso, as variáveis que originaram os conglomerados. Para cada variável é obtida a estatística F e quanto maior o seu valor, maior a relevância da variável para discriminar os conglomerados.

Além disso, o nível de significância das variáveis é outro aspecto que deve ser verificado na ANOVA, visto que se alguma variável apresentar nível de significância maior do que 0,05 ; esta deverá ser retirada e os dados restantes deverão ser reprocessados. 


\section{2 - Abordagem qualitativa}

Como mencionado anteriormente, este estudo é classificado como sequencial explanatório (CRESWELL, 2003). Bryman (1992 apud Flick, 2004) acredita que uma das formas de integração entre pesquisa quantitativa e qualitativa é aquela em que os resultados qualitativos podem facilitar a interpretação das relações entre variáveis em conjuntos de dados quantitativos.

Sendo assim, o propósito da segunda etapa da pesquisa foi evidenciar resultados qualitativos que pudessem ilustrar, explicar e auxiliar nas interpretações das descobertas da primeira fase, da etapa quantitativa.

$\mathrm{Na}$ abordagem qualitativa "[...] o interesse está em verificar como determinado fenômeno se manifesta nas atividades, procedimentos e interações diárias” (GODOY, 1995, p. 63). Por meio das técnicas de coleta de dados em uma multinacional brasileira, pretendeu-se compreender como ocorre a transferência de conhecimento entre a matriz e a subsidiária considerando as interações organizacionais, além de elucidar os aspectos culturais que podem favorecer ou dificultar tal processo, assim como a iniciativa da unidade.

Para Flick (2004, p. 66), “uma característica central de qualquer bom desenho de pesquisa [...] é seu potencial para limitar o foco do estudo planejado". Assim, a fim de explicitar o processo de realização da pesquisa qualitativa, a Ilustração 10 apresenta o fluxo das etapas realizadas, as quais são detalhadas. 


\section{Objetivo Geral:}

Analisar a influência da transferência de conhecimento e de fatores culturais na iniciativa das subsidiárias de multinacionais brasileiras

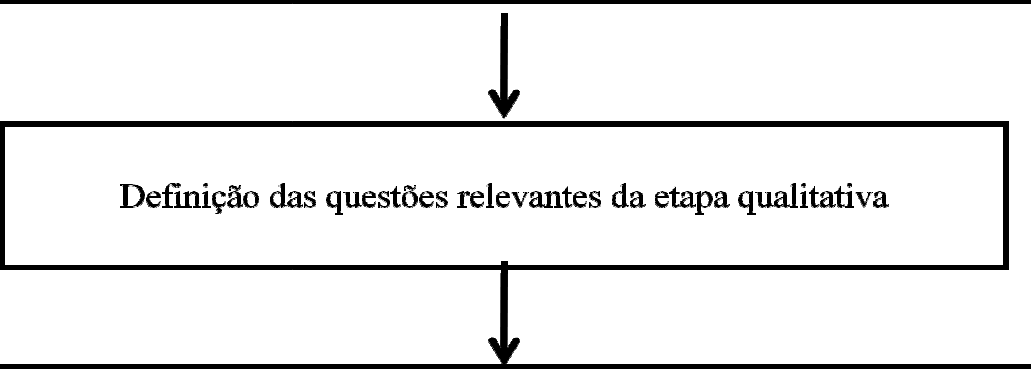

Elaboração dos instrumentos de coleta de dados: roteiro de entrevista semiestruturado e questionário

Escolha da multinacional brasileira do estudo

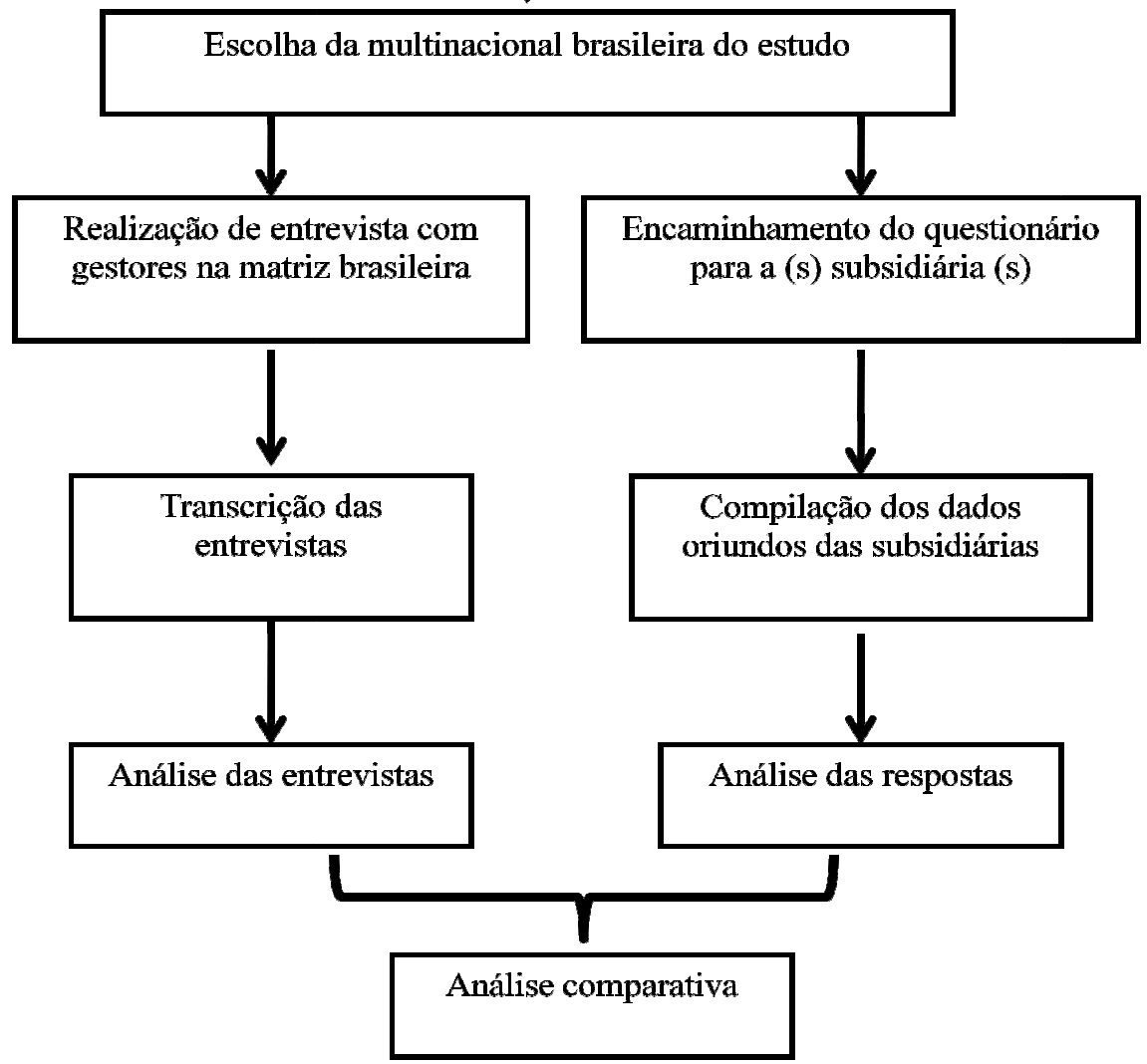

Ilustração 10 - Desenho da pesquisa qualitativa 


\subsection{1 - Dimensões de análise}

Considerando-se o propósito da abordagem qualitativa, o arcabouço teórico e o objetivo geral do estudo, elencou questões centrais que facilitassem a condução da pesquisa, bem como a elaboração dos instrumentos de coletas de dados.

Cabe salientar, entretanto, que foram mantidos os mesmos construtos identificados e utilizados no questionário da etapa quantitativa, sendo denominados de dimensões: transferência de conhecimento, cultura e iniciativa (interna e externa). As principais questões norteadoras da etapa qualitativa são apresentadas no Quadro 20.

Quadro 20 - Dimensões e questões norteadoras da etapa qualitativa

\begin{tabular}{|c|c|c|}
\hline Dimensões & Questões Norteadoras & Referencial \\
\hline $\begin{array}{l}\text { Transferência de } \\
\text { conhecimento }\end{array}$ & $\begin{array}{l}\text { - Como ocorre o processo de transferência de conhecimento entre } \\
\text { as unidades da multinacional? } \\
\text { - Quais são os principais meios utilizados na transferência de } \\
\text { conhecimento entre as unidades? } \\
\text { - Existe alguma dificuldade neste processo? Quais são as } \\
\text { barreiras mais freqüentes? }\end{array}$ & $\begin{array}{c}\text { Gupta e } \\
\text { Govindarajan (2000) }\end{array}$ \\
\hline Cultura Nacional & $\begin{array}{l}\text { - Quais são os aspectos de destaque (positivo e negativo) da } \\
\text { cultura dos países onde estão as unidades da multinacional? } \\
\text { - Esses aspectos influenciam (facilitam ou dificultam) o processo } \\
\text { de transferência de conhecimento entre as unidades? } \\
\text { - De que maneira esses aspectos influenciam (facilitam ou } \\
\text { dificultam) a gestão da unidade? }\end{array}$ & Hofstede (2005) \\
\hline Iniciativa interna & $\begin{array}{l}\text { - Considerando o contexto da multinacional, a subsidiária busca } \\
\text { novas oportunidades de negócios para expandir a sua atuação? } \\
\text { Como? } \\
\text { - De que maneira, a transferência de conhecimento entre a matriz } \\
\text { e a subsidiária facilita e/ou dificulta a identificação dessas novas } \\
\text { oportunidades? } \\
\text { - A matriz reconhece as iniciativas da subsidiária? Como? }\end{array}$ & Birkinshaw (1997) \\
\hline Iniciativa externa & $\begin{array}{l}\text { - A subsidiária tem contato direto com os clientes, fornecedores e } \\
\text { entidades governamentais no seu contexto local? Como? } \\
\text { - A subsidiária identifica oportunidades de negócios a partir } \\
\text { desses contatos? Como? }\end{array}$ & $\begin{array}{c}\text { Andersson e } \\
\text { Forsgren (2002) }\end{array}$ \\
\hline
\end{tabular}

\subsection{2 - Escolha da multinacional e a amostragem}

Uma das grandes dificuldades na realização de pesquisas qualitativas é o acesso aos respondentes, principalmente quando envolvem instituições e organizações que possuem vários níveis hierárquicos, o que pode dificultar a concordância e a concessão desta para a realização do estudo. Flick (2004, p.54) destaca que "conseguir acesso a campos, instituições ou pessoas pode ser um processo longo e difícil". 
O critério principal de escolha da multinacional para ser o foco de estudo desta etapa foi a participação na primeira fase, além de possuir subsidiárias na amostra analisada. Considerouse também a disponibilidade de colaboração com o estudo por parte da organização. Desta maneira, a Weg S.A. foi a empresa analisada nesta segunda etapa do estudo, melhor apresentada no capítulo dos resultados qualitativos.

A amostragem na pesquisa qualitativa se apresenta de duas maneiras básicas: i) mais formais, com critérios previamente definidos, e ii) mais flexíveis, com foco nas necessidades que aparecem durante a realização da pesquisa (FLICK, 2004). Para o presente estudo, o processo ocorreu de forma mais flexível, visto que não foi definido de antemão o número de entrevistas na matriz brasileira, bem como nas unidades estrangeiras.

\subsection{3 - Instrumentos e coleta de dados}

Para a coleta de dados primários desta etapa do estudo, ou seja, na multinacional brasileira, adotou-se duas técnicas principais: entrevistas semi-estruturadas e questionários on-line. No Quadro 21 é apresentada uma síntese das técnicas de coleta de dados utilizadas, assim como o seu propósito e a fonte mais indicada e recorrida.

\begin{tabular}{|c|l|c|}
\hline $\begin{array}{c}\text { Técnica de } \\
\text { coleta de } \\
\text { dados }\end{array}$ & \multicolumn{1}{|c|}{ Puadro 21- Técnicas e fontes de coletas de dados qualitativos } & \multicolumn{1}{|c|}{ Pronte } \\
\hline $\begin{array}{c}\text { Entrevista semi } \\
\text { estruturada }\end{array}$ & $\begin{array}{l}\text { - Caracterização da empresa e processo de internacionalização } \\
\text { - Identificar como ocorre o processo de transferência de conhecimento } \\
\text { (mecanismos e barreiras) entre a matriz e a subsidiária } \\
\text { - Percepção da matriz sobre aspectos da cultura local do país da subsidiária e e } \\
\text { os impactos na transferência de conhecimento e iniciativa } \\
\text { - Visão da matriz sobre a iniciativa da subsidiária } \\
\text { - Identificar o modelo de gestão das subsidiárias }\end{array}$ & Gestor na matriz \\
\hline $\begin{array}{c}\text { Questionário } \\
\text { na internet (on- } \\
\text { line) }\end{array}$ & $\begin{array}{l}\text { - Caracterização da subsidiária } \\
\text { - Compreender aspectos culturais do país } \\
\text { - Identificar como ocorre o processo de transferência de conhecimento } \\
\text { - Compreender a iniciativa da subsidiária e o reconhecimento desta pela } \\
\text { matriz } \\
\text { - Percepção sobre a iniciativa da subsidiária, considerando aspectos da } \\
\text { cultura local do país e a transferência de conhecimento na multinacional } \\
\text { brasileira. }\end{array}$ & Gestores das \\
subsidiárias
\end{tabular}


Durante o desenvolvimento da pesquisa, a coleta de dados secundários teve como objetivos principais a busca do histórico da multinacional, mais particularmente do conhecimento do negócio, do processo de internacionalização e de evidências relacionadas diretamente ao objetivo do estudo. Para tanto, fez-se levantamentos de dados secundários, tais como os documentos internos da organização (relatórios e compêndios históricos), notícias da imprensa, bem como trabalhos acadêmicos que pudessem ser fontes riquíssimas de evidências para as análises deste estudo.

Visto que as entrevistas semi-estruturadas e os questionários on-line foram as técnicas principais para a coleta de dados, são melhores exploradas a seguir.

\section{a) Entrevista}

A entrevista é recomendada para situações em que o pesquisador deseja conhecer as opiniões e ideias do entrevistado sobre um dado fenômeno.

Sobre a entrevista, Dencker e Viá (2001) ressaltam que a importância desta técnica é permitir a obtenção de informações que não podem ser encontradas somente em registros ou fontes documentais. Desta forma, é possível utilizar-se das respostas obtidas para construir um conhecimento a respeito dos aspectos relacionados aos objetivos da pesquisa proposta.

Para Minayo (2000), a entrevista, como fonte de informação, fornece dados primários e secundários, referentes a fatos, opiniões, maneiras de atuar, condutas, razões conscientes ou inconscientes. No entanto, como as entrevistas estão sujeitas a problemas, tais como preconceito, memória fraca e articulação pobre ou imprecisa, deve-se confrontar os dados obtidos por meio destas com informações advindas de outras fontes.

Dentre os tipos existentes, optou-se pela entrevista semi-estruturada, na qual o entrevistador deve fazer certo número de perguntas principais e específicas, mas com liberdade para ir além das respostas dadas às perguntas e gerar novos questionamentos não programados antecipadamente.

O instrumento de coleta de dados utilizado foi um roteiro de entrevista semi-estruturado (Apêndice 1) aplicado a dois gestores de exportação da matriz brasileira, tendo como objetivo principal investigar as características gerais da organização, o processo de internacionalização, a relação com as subsidiárias, bem como os aspectos chave deste estudo: iniciativa, transferência de conhecimento e cultura. 
As entrevistas, gravadas na íntegra, foram realizadas em junho de 2010, nas dependências da organização em Jaraguá do Sul, Santa Catarina. Naquele momento, entrevistou-se dois gerentes de comércio exterior, formados em engenharia elétrica e com carreira sólida na organização, onde atuam há mais de 20 anos.

Assim, tais entrevistas permitiram uma compreensão quanto ao olhar da matriz sobre o relacionamento desta com as unidades estrangeiras, bem como a percepção da multinacional brasileira sobre o seu desenvolvimento.

\section{b) Questionário}

Apesar de não ser frequente nas abordagens qualitativas, o uso de questionários como técnica de coleta de dados é vantajoso porque possibilita atingir grande número de pessoas, mesmo que estejam dispersas em uma área geográfica muito extensa, além de não expor os pesquisados à influência das opiniões e do aspecto pessoal do entrevistador.

Segundo Sudman e Bradburn (1982), os questionários não devem ser extensos, mas apropriados aos objetivos da pesquisa, contendo questões estruturadas e/ou semi-estruturadas, formuladas de acordo com a natureza das variáveis a serem estudadas e a forma como serão conduzidos.

$\mathrm{Na}$ oportunidade das entrevistas com os gestores na matriz, foi solicitado que o questionário com perguntas fechadas e abertas fosse colocado à disposição dos gestores da subsidiária. Yeung (1995 apud Marschan-Piekkari et al, 2004) salienta que o acesso às subsidiárias de multinacionais é um grande desafio para os pesquisadores na área de negócios internacionais e que um bom relacionamento com os executivos na matriz pode facilitar tal contato com as unidades.

O intuito da realização do questionário foi compreender como ocorre o processo de transferência de conhecimento entre as unidades e identificar os mecanismos e as barreiras existentes, bem como a percepção sobre a iniciativa da subsidiária, considerando aspectos da cultura local e da cultura organizacional da multinacional.

O questionário auto-preenchido (Apêndice 2) conteve quatro partes principais: i) questões relacionadas aos brasileiros expatriados e as relações destes com colaboradores locais; ii) indagações sobre a cultura local e a cultura organizacional e seus impactos na gestão da 
unidade; iii) o processo de transferência de conhecimento e, por fim, as iv) oportunidades de negócios.

Para responder ao questionário auto preenchido, eram necessários, no máximo, 20 minutos. Realizou-se um pré-teste para a validação das questões. $O$ passo seguinte foi a tradução do mesmo para o inglês e espanhol, a fim de facilitar e incentivar os respondentes a participarem.

Após a tradução, o questionário foi disponibilizado às unidades respondentes, via internet, de forma a facilitar o processo. A partir do retorno dos mesmos, foi criado um banco de dados com todas as respostas, o que facilitou o processo posterior de análise dos dados.

Para o sucesso na obtenção do maior número possível de respondentes dentre as 22 unidades estrangeiras da multinacional brasileira, contou-se com o apoio da matriz na divulgação do link de acesso ao questionário nos três idiomas.

No período de junho a julho de 2010, os questionários auto-preenchidos ficaram disponíveis. Ao final deste período, obteve-se respostas de oito unidades internacionais da Weg, compreendendo seis escritórios (Bélgica, Itália, Espanha, Austrália, Cingapura e Chile) e duas plantas fabris (Argentina e México).

Os questionários das oito unidades foram respondidos pelos seus respectivos diretores, os quais são engenheiros elétricos de formação e tempo na unidade oscilando entre seis meses (brasileiros expatriados) à catorze anos. Dentre os oito respondentes, há um belga, um italiano, um espanhol e cinco brasileiros.

Assim, considerou-se os resultados coletados por meio desses questionários respondidos pelos oito diretores de filiais (escritórios e plantas) da Weg, como a visão das subsidiárias sobre os aspectos chaves deste estudo.

\subsection{4 - Análise dos dados}

$\mathrm{Na}$ pesquisa qualitativa, a análise dos dados envolve dois aspectos: manipulação e interpretação (GIBBS, 2009). O tipo mais comum de dado qualitativo usado em análise é o texto, representado neste estudo pelas entrevistas na matriz da multinacional brasileira e pelas respostas dos questionários das subsidiárias. 
Visando facilitar o processo de análise, o conteúdo das entrevistas foi transcrito na íntegra em texto digitado e as respostas dos diretores das subsidiárias foram compiladas em um único arquivo digital, organizado por perguntas. Cabe salientar que, apesar de o questionário direcionado às unidades estrangeiras possuir algumas perguntas fechadas e, do considerado o número reduzido de respondentes, todos os dados foram tratados de maneira qualitativa.

Para analisar os dados oriundos desta etapa, optou-se inicialmente por explorar os resultados das técnicas e dos instrumentos de coleta de dados separadamente, visto que buscaram identificar percepções de contextos distintos: matriz e subsidiárias, respectivamente.

Ressalta-se que em ambos os processos de apresentação dos dados e análise (matriz e subsidiárias), tanto o objetivo geral do estudo quanto as questões norteadoras foram os fios condutores na exploração dos construtos: transferência de conhecimento, cultura e iniciativa das subsidiárias.

Durante a explanação dos resultados, trechos das entrevistas e das respostas abertas do questionário foram destacados e apresentados como evidências que pudessem confirmar ou ilustrar determinada reflexão. Visando garantir o anonimato de todos os participantes, utilizou-se códigos para identificá-los.

Por fim, realizou-se uma análise comparativa entre as percepções da matriz e das subsidiárias, tendo como ponto de partida os construtos (categorias de análise) do estudo. Os resultados foram discutidos à luz das teorias de internacionalização e do modelo proposto no presente trabalho, relacionando os três construtos principais: iniciativa da subsidiária, transferência de conhecimento e cultura. 


\section{5 - APRESENTAÇÃO E ANÁLISE DOS RESULTADOS QUANTITATIVOS}

Conforme explicitado no capítulo da metodologia, este estudo apresenta-se com métodos mistos, conciliando abordagem quantitativa com a qualitativa. De acordo com a classificação de Creswell (2003), a estratégia utilizada foi a sequencial explanatória, na qual a coleta e análise de dados quantitativos precedeu a de dados qualitativos.

Desta maneira, neste capítulo, apresentam-se os resultados e a análise dos dados obtidos na etapa quantitativa e, para o processamento dos dados, foi utilizada a planilha de cálculo Microsoft Excel e os pacotes de análise estatística SPSS - Statistical Package for Social Sciences, versão 13 e, SmartPLS versão 2.0 M3 (RINGLE et al, 2005).

Cabe salientar, no entanto, que para melhor exploração dos resultados, a análise é apresentada pelos seguintes objetivos específicos:

- Explorar o processo de transferência de conhecimento entre a subsidiária e a matriz;

- Identificar características da cultura da subsidiária;

- Analisar a influência da cultura e da transferência de conhecimento na iniciativa da subsidiaria;

- Identificar se a cultura, a transferência de conhecimento e a iniciativa permitem a configuração de grupos homogêneos de subsidiárias.

\section{1 - O processo de transferência de conhecimento entre a subsidiária e a matriz}

O processo de transferência de conhecimento entre a subsidiária e a matriz ocorre por meio de mecanismos, como reuniões com executivos brasileiros, realização de viagens dos colaboradores da subsidiária, movimentação de executivos, utilização de manuais de orientação e implementação, benchmarking interno, banco de melhores práticas, consultores especializados e equipes de projetos. No entanto, nem sempre a transferência de conhecimento em ambos os sentidos é eficiente e eficaz, devido as barreiras ao processo. 
Inicialmente, a partir de uma amostra de 66 subsidiárias, nesta seção explora-se o processo de transferência de conhecimento entre a subsidiária e a matriz, seguido pela apresentação das barreiras existentes identificadas no levantamento.

Alguns estudos internacionais (MEYER et al, 2009; KOGUT; SINGH, 1988; BRESMAN et al, 1999; GUPTA; GOVINDARAJAN, 2000; BJORKMAN, 2004) apontam que existem diferenças no processos de transferência de conhecimento nas multinacionais em relação à forma como as subsidiárias foram criadas. Desta maneira, visando explorar esta situação no contexto das subsidiárias de multinacionais brasileiras, é apresentada a análise comparativa entre as unidades provenientes de greenfield (25 unidades) e de aquisição (41 unidades).

\subsection{1 - Mecanismos de transferência de conhecimento}

Como explicitado no capítulo dos procedimentos metodológicos, no instrumento de coleta de dados foram utilizadas dez afirmativas referentes ao processo de transferência da matriz para a subsidiária e a mesma quantidade de afirmativas para analisar os mecanismos no sentido oposto. Cabe salientar que ambas as questões foram respondidas pela subsidiária, ou seja, é dela a percepção em relação aos mecanismos de transferência nos dois sentidos.

Ressalta-se que para cada afirmativa, numa escala likert, o respondente da subsidiária deveria assinalar aquela que melhor representasse a situação naquele momento. Entretanto, para análise dos dados, foram consideradas as respostas concordo e concordo plenamente, visto que o intuito principal era analisar os mecanismos de transferência de conhecimento mais utilizados entre a matriz e a subsidiária.

A partir disso, fez-se a comparação dos mecanismos de transferência de conhecimento nos dois sentidos: matriz para subsidiária e, da subsidiária para matriz e demais subsidiárias. Os resultados sintetizados são demonstrados na Tabela 3 , evidenciando o percentual de concordância dos mecanismos em relação a maneira como a unidade foi criada. 
Tabela 3 - Mecanismos de transferência de conhecimento utilizados pelas multinacionais brasileiras

\begin{tabular}{l|ccc|ccc}
\hline \multicolumn{1}{c}{$\begin{array}{c}\text { Mecanismos de transferência de } \\
\text { conhecimento }\end{array}$} & \multicolumn{3}{c|}{ TC da matriz } & \multicolumn{3}{c}{ TC da subsidiária } \\
\cline { 2 - 7 } & greenfield & aquisição & Geral & greenfield & aquisição & Geral \\
\hline Reuniões com os executivos principais da matriz & $72,0 \%$ & $90,6 \%$ & $80,3 \%$ & $56,0 \%$ & $43,8 \%$ & $51,5 \%$ \\
Deslocamento de executivos & $72,0 \%$ & $84,4 \%$ & $77,3 \%$ & $28,0 \%$ & $25,0 \%$ & $25,8 \%$ \\
Viagens para a matriz & $64,0 \%$ & $75,0 \%$ & $65,2 \%$ & $52,0 \%$ & $34,4 \%$ & $40,9 \%$ \\
Manuais de orientação & $48,0 \%$ & $78,1 \%$ & $63,6 \%$ & $28,0 \%$ & $15,6 \%$ & $19,7 \%$ \\
Práticas de treinamento & $52,0 \%$ & $71,9 \%$ & $57,6 \%$ & $36,0 \%$ & $18,8 \%$ & $24,2 \%$ \\
Benchmarking interno & $44,0 \%$ & $68,8 \%$ & $53,0 \%$ & $16,0 \%$ & $12,5 \%$ & $16,7 \%$ \\
Banco de melhores práticas & $40,0 \%$ & $53,1 \%$ & $43,9 \%$ & $28,0 \%$ & $9,4 \%$ & $19,7 \%$ \\
Consultores & $36,0 \%$ & $25,0 \%$ & $43,9 \%$ & $4,0 \%$ & $15,6 \%$ & $10,6 \%$ \\
Equipes de projetos & $28,0 \%$ & $31,3 \%$ & $27,3 \%$ & $16,0 \%$ & $6,3 \%$ & $12,1 \%$ \\
\hline
\end{tabular}

A realização de reuniões com executivos da matriz é um dos mecanismos de transferência de conhecimentos mais utilizados no contexto das multinacionais. No entanto, considerando-se a amostra analisada, observa-se na Tabela 3, que a reunião com executivos brasileiros é uma prática predominante da matriz para a subsidiária (80,3\%), enquanto que apenas $51,5 \%$ dos respondentes acreditam que esta seja uma prática nos processos inversos, da subsidiária para a matriz.

É interessante destacar que a realização de reuniões com executivos da matriz está mais presente como forma de relacionamento da matriz com as subsidiárias decorrentes de aquisições $(90,6 \%)$ do que com as greenfield (72\%), provavelmente pelo fato de as primeiras serem processos que proporcionem pleno controle da unidade brasileira. No sentido oposto, há menor participação e possibilidade de reuniões com a matriz por parte das unidades adquiridas $(43,8 \%)$ em relação às oriundas de greenfield $(56 \%)$.

Quanto à existência e criação de manuais de orientação e implementação, 63,6\% subsidiárias recebem os manuais da matriz e seguem suas orientações, sendo por isso um ótimo mecanismo de disseminação do conhecimento.

O desejo da matriz brasileira, em implementar seu processo produtivo em subsidiárias provenientes de processos de aquisição em substituição a práticas anteriores, pode ser o motivo pelo qual há expressivo uso deste mecanismo de transferência nas unidades adquiridas $(78,1 \%)$, enquanto que nas greenfield, apenas $48 \%$ das unidades indicaram a existência de ações similares. 
Observa-se que não se caracteriza uma prática de transferência de conhecimento da subsidiária para a matriz visto que somente $19,7 \%$ dos respondentes concordam com a existência de tal mecanismo.

A expatriação, movimentação de executivos, principalmente da matriz brasileira para as subsidiárias é outra prática que propicia a transferência de conhecimento, segundo 77,3\% das subsidiárias respondentes. Observa-se que é um mecanismo existente em ambos os tipos de subsidiárias, sendo mais expressivo no caso de processos de aquisição (84,4\%). Este alto valor nas subsidiárias adquiridas pode representar certo zelo por parte da matriz com estas unidades, utilizando os expatriados como forma de redefinir as práticas locais e aumentar o controle sobre a unidade.

No entanto, nota-se que o mesmo não acontece no sentido das subsidiárias para a matriz, pois esta se apresenta como uma prática verificada na unidade somente para $25,8 \%$ dos respondentes. Logo, não há a preocupação, pelo menos em um primeiro momento, de que executivos das subsidiárias desenvolvam trabalhos de médio ou longo período na matriz brasileira ou em subsidiárias em outros países.

Este resultado pode mesmo ser tão somente reflexo do fato de as multinacionais brasileiras serem novas e, por isso, do fluxo de repatriados, da subsidiária para a matriz, ainda ser incipiente, quando comparado ao fluxo de expatriados, da matriz para a subsidiária.

A realização ou participação em treinamentos na matriz aparece como uma forma usual de se transmitir os conhecimentos apenas da sede para as filiais (Tabela 3). Se por um lado, 57,6\% dos respondentes afirmaram que os colaboradores da subsidiária participam em treinamentos na matriz visando a transferência de conhecimento desta para aquela; por outro, apenas $24,2 \%$ indicaram que as subsidiárias participam de treinamentos na matriz a fim de transferir de conhecimento originado na unidade.

Cabe, novamente, destacar que as subsidiárias oriundas de aquisição $(71,9 \%)$ são as que apresentam maior participação em treinamentos na matriz, o que representa, mais uma vez, a preocupação das multinacionais brasileiras em promover disseminação das suas políticas e práticas gerenciais, especialmente para as unidades adquiridas. Em contrapartida, resultado apresentado pelas subsidiárias greenfield no processo de transferência de conhecimento da subsidiária para a matriz por meio de práticas de treinamento $(36 \%)$ reforça a ideia de que a prática de benchmarking interno é mais ativa nestas do que nas subsidiárias adquiridas. 
Assim, como no caso dos treinamentos, as viagens de colaboradores da subsidiária para a matriz aparecem como um forte mecanismo de transferência de conhecimento, conforme foi afirmado por $65,2 \%$ das respondentes. Igualmente, os casos de subsidiárias provenientes de processos de aquisição destacam-se pelo uso deste mecanismo (75\%). Ressalta-se que esta estratégia é utilizada, principalmente, como forma de transferência de conhecimento da matriz para a subsidiária, proporcionando aos colaboradores estrangeiros um contato maior com as rotinas e processos produtivos nas unidades brasileiras.

Sobre os resultados referentes ao direcionamento das atividades e à autonomia das unidades para implementá-las, enfatiza-se que, a afirmativa proposta no questionário teve como objetivo verificar o quanto a subsidiária recebe de ordens da matriz e como as implementa, e com qual grau de liberdade faz os ajustes necessários. Conforme os dados apresentados, apenas $15,2 \%$ dos respondentes afirmaram que as subsidiárias gozam de autonomia para implementar procedimentos a sua própria maneira. Assim, evidencia-se que o estilo de gestão das multinacionais brasileiras é caracterizado predominantemente pela centralização das decisões, fator este, que pode inibir a iniciativa das subsidiárias.

Além disso, quando a subsidiária propõe algo, percebe-se que há abertura para novas ideias e melhorias de processos, no entanto a implementação acontece conforme a matriz acredita ser melhor.

Observa-se que 53\% das subsidiárias acreditam que há realização de benchmarking, porém a disseminação de práticas e políticas da corporação, ocorre sobretudo da matriz para as subsidiárias, já que no sentido inverso o percentual é de apenas $16,7 \%$, e é mais evidente em subsidiárias oriundas de processos de aquisição $(68,8 \%)$.

Assim como o benchmarking, a estruturação de bancos de melhores práticas é uma forma eficaz de transferência de conhecimento no ambiente das multinacionais. Na amostra analisada, observou-se que 43,9\% responderam que este é um mecanismo de transferência de conhecimento da matriz para a subsidiária, sendo mais evidente para aquelas, oriundas de processos de aquisição $(53,1 \%)$.

A contratação de consultores especializados foi reconhecida como prática de transferência de conhecimento da matriz para a subsidiária por $43,9 \%$ dos respondentes no geral. Em relação às unidades greenfield, $36 \%$ identificaram este mecanismo como de transferência de conhecimento da matriz para a subsidiária. 
Por fim, outro mecanismo de transferência de conhecimento existente é o deslocamento de equipes de projetos responsáveis pela implementação dos processos e atividades nas unidades. Observando-se a Tabela 3, percebe-se que as equipes de projetos são mais frequentes $(27,3 \%)$ no sentido da matriz para a subsidiária, o que demonstra mais uma vez a preocupação da primeira em assegurar a manutenção de seus modelos de gestão e de suas práticas na segunda. É notável que tal prática seja mais expressiva nas subsidiárias provenientes de aquisições $(31,3 \%)$.

\subsubsection{1 - Síntese sobre os mecanismos de transferência de conhecimento}

Os resultados apresentados na seção anterior indicam que as multinacionais brasileiras utilizam-se de mecanismos de transferência de conhecimento entre as unidades, preferencialmente com processos da matriz para a subsidiária, conforme explicitado por Oliveira Junior e Borini (2010), o que demonstra que as sedes brasileiras buscam difundir seus procedimentos, práticas e modelos de gestão para as demais unidades. Este comportamento é consoante com o que Bhagat et al (2002) concluíram sobre o Brasil e, por apresentar um alto índice de distância do poder (conforme a classificação do Hofstede, 2001), caracteriza-se como uma cultura vertical, na qual o fluxo de informações ocorre de cima para baixo, ou seja, da matriz para as unidades estrangeiras.

A realização de reuniões com os principais executivos da matriz tem sido a prática predominante de transferência de conhecimento nas multinacionais brasileiras, em ambos os sentidos: da matriz para a subsidiária e vice-versa. Este tipo de estratégia tende a ser utilizada quando o objetivo é a transferência de conhecimentos tácitos, inerentes aos profissionais da matriz, que por meio da socialização e externalização, compartilham com os gestores da subsidiária os conhecimentos relevantes para a operacionalização do negócio.

No caso da transferência de conhecimento da subsidiária para a matriz, a realização de viagens para a matriz é o segundo mecanismo mais utilizado, o que revela a existência da preocupação para que os profissionais das unidades conheçam e compreendam os processos e sistemas organizacionais de perto, em visitas e permanências na matriz por um período suficiente. Novamente, o compartilhamento do conhecimento tácito por meio de processos de socialização é fundamental. 
Outro mecanismo de transferência da matriz para as subsidiárias das empresas brasileiras, utilizado em alto grau, é o deslocamento de executivos brasileiros para as unidades, em muitos casos, por meio de expatriações, o que possibilita transferir muitas informações por vez, permitindo uma alta interação entre os indivíduos (emissor e receptor).

Cabe salientar que apesar de o deslocamento de executivos proporcionar alta interatividade entre os colaboradores, mostrou-se uma prática pouco utilizada como mecanismos de transferência de conhecimento das subsidiárias para a matriz nas multinacionais brasileiras. Uma explicação para este acontecimento é o limitado tempo de internacionalização das empresas brasileiras, fazendo com que os fluxos priorizem os processos/conhecimentos no sentido da matriz para a subsidiária.

\section{A realização de treinamentos e viagens na matriz também aparecem como práticas} comuns, tendo como intenção o deslocamento de profissionais da subsidiária para a matriz com o objetivo de transferência de conhecimentos, predominantes tácitos, além da oportunidade de contato com a cultura local. Cabe salientar que a realização de treinamentos na matriz é um dos mecanismos mais utilizado para transferir conhecimento desta para as unidades, enquanto as viagens ocorrem com o propósito de disseminação das experiências em ambos os sentidos.

Como forma de transferência de conhecimento da matriz para as subsidiárias brasileiras destaca-se ainda a utilização de manuais de orientação, indicando o direcionamento das decisões e informações conforme a hierarquia top-down (cima para baixo), ou seja, da matriz centralizadora de decisão para as unidades.

As multinacionais brasileiras utilizam muito mais mecanismos pessoais de transferência de conhecimento do que de ferramentas eletrônicas, com a intenção de sempre criar oportunidades de socialização e externalização do conhecimento, visto que é observável que uma característica cultural brasileira é a necessidade de contato físico (pessoal) entre as pessoas. Bhagat et al. (2002) identificaram que nas culturas coletivistas, como a existente no Brasil, os indivíduos tendem a considerar o contexto da informação e não se vinculam a questões formais, privilegiando contatos mais informais.

É importante evidenciar que existem algumas particularidades nos processos de transferência de conhecimento e que estes ocorrem diferentemente entre as subsidiárias adquiridas e as greenfield. No que diz respeito à transferência de conhecimento da matriz para a subsidiária, o 
alvo principal é a filial adquirida, já, no sentido inverso, quando há transferência de conhecimento da subsidiária para a sede, os processos são mais frequentemente associados à filial greenfield. Exceto, no caso de consultorias, quando estas recebem mais transferência de conhecimento da sede do que o inverso e quando aquelas transferem mais do que recebem.

Nos processos de transferência de conhecimento da matriz para a subsidiária, a primazia é maior para as unidades provenientes de aquisições, quando comparadas às greenfield. Esta transferência de conhecimento intensa entre a matriz e as subsidiárias adquiridas é fundamental para a criação de valor do negócio (BRESMAN et al, 1999, 2010), ou seja, permite um aprendizado (MEYER et al, 2009) e a partilha de recursos entre as partes (adquirido e adquirente), bem como o aumento de economia de escalas, redução de custos e maior variedade de produtos e serviços para oferecer ao mercado.

Outra justificativa para essa ocorrência é o fato de a maioria das unidades adquiridas ser jovens o que, conforme evidenciado por Bresman et al (1999, 2010), é uma prática comum no estágio inicial pós aquisição, devido a falta de relacionamento e confiança entre os indivíduos das duas unidades originais, bem como a ocorrência de mal-entendidos diante das diferenças culturais entre as sociedades.

No sentido oposto, da subsidiária para a matriz, as unidades oriundas de aquisições, utilizam pouco os mecanismos de transferência de conhecimento. Com isso, as multinacionais brasileiras podem estar perdendo conhecimentos relevantes, visto que, segundo Bjorkman (2004), unidades adquiridas podem possuir conhecimentos mais diferenciados para o contexto organizacional do que as greenfield, pois detêm conhecimentos sobre o contexto local.

A literatura sobre gestão do conhecimento (GUPTA; GOVINDARAJAN, 2000) em multinacionais aponta que a disseminação dos conhecimentos gerados nas subsidiárias é mais intensa a partir das unidades adquiridas quando comparadas às greenfield. Entretanto, diferente disto, os resultados indicam que as unidades greenfield brasileiras utilizam mais os mecanismos de transferência de conhecimento delas para a matriz, quando comparado às adquiridas.

Essa evidência pode ser decorrência das unidades greenfield, na sua maioria, apresentarem alta capacidade de absorção (GUPTA; GOVINDARAJAN, 2000; MINBAEVA et al., 2003), o que representa a habilidade de reconhecer o valor de uma nova informação externa, assimilá-la e aplicá-la aos processos gerenciais. Assim, a medida em que a unidade passa a 
conhecer a dinâmica organizacional se torna mais fácil a interação com a unidade mãe, podendo, inclusive, contribuir com sugestões para a melhoria dos processos.

Assim, em relação à transferência de conhecimento da matriz para a subsidiária, observa-se que as reuniões com os principais executivos da matriz e a recepção de brasileiros executivos são as duas práticas mais utilizadas em ambos os tipos de unidades: aquisição e greenfield; como indicado no Quadro 22, o qual proporciona uma visão geral, em ordem decrescente de importância, dos principais mecanismos utilizados no ambiente corporativo internacional das multinacionais brasileiras.

Quadro 22 - Síntese dos principais mecanismos de transferência de conhecimento

\begin{tabular}{|c|c|c|}
\hline & Matriz para Subsidiária & Subsidiária para Matriz \\
\hline Aquisição & $\begin{array}{l}\text { 1. Realização de reuniões com os executivos } \\
\text { principais da matriz; } \\
\text { 2. Deslocamento de executivos brasileiros; } \\
\text { 3. Utilização de manuais de orientação e } \\
\text { implementação; } \\
\text { 4. Realização de viagens para a matriz. }\end{array}$ & \multirow{2}{*}{$\begin{array}{l}\text { 1. Realização de reuniões com } \\
\text { os principais executivos da matriz; } \\
\text { 2. Realização de viagens para a } \\
\text { matriz. }\end{array}$} \\
\hline Greenfield & $\begin{array}{l}\text { 1. Realização de reuniões com os executivos } \\
\text { principais da matriz e deslocamento de } \\
\text { executivos brasileiros; } \\
\text { 2. Realização de viagens para a matriz; } \\
\text { 3. Prática de treinamento. }\end{array}$ & \\
\hline
\end{tabular}

Ainda sobre a transferência da matriz para a subsidiária, a realização de viagens para a matriz aparece como uma das quatro práticas utilizadas para todas as unidades, sendo mais relevantes para as greenfield do que para as provenientes de processo de aquisição.

Para as subsidiárias oriundas de aquisição, além desse mecanismo, há a utilização de manuais de orientação e implementação. Nestes casos, a presença brasileira é muito importante para a adequação, não somente dos processos e práticas, mas também do estilo de gestão e das características da cultura organizacional. Todavia, as unidades greenfield, por tratar de investimentos iniciais diretos em outros países, necessitam muito mais dos conhecimentos da matriz, provenientes de práticas de treinamento.

Entretanto, no sentido oposto, dos fluxos das práticas e conhecimentos da subsidiária para a matriz, tanto para as unidades adquiridas quanto para as de greenfield, a realização de reuniões com os principais executivos e as viagens para a matriz são as práticas mais utilizadas. 
Logo, as subsidiárias brasileiras caracterizam-se como receptoras de conhecimento, com predomínio de papel passivo, seguindo as orientações da matriz brasileira. Cabe salientar que existe transferência de conhecimento da subsidiária para a matriz, mas ainda como um processo lento e tímido, talvez decorrente do pouco tempo de existência das multinacionais brasileiras.

\subsection{2 - Barreiras à transferência de conhecimento}

Com o intuito de identificar a existência ou não de barreiras à transferência de conhecimento da matriz para a subsidiária, foram utilizadas oito afirmativas no questionário e, a mesma quantidade de enunciados para a análise no sentido oposto. No entanto, assim como nos mecanismos de transferência de conhecimento, ambas as questões foram respondidas pela subsidiária, ou seja, a percepção desta em relação às barreiras na transferência de conhecimento é feita nos dois sentidos.

Ressalta-se que para cada afirmativa, numa escala likert, o respondente da subsidiária deveria assinalar aquela que melhor representasse a situação naquele momento. Entretanto, para análise dos dados, foram consideradas as respostas concordo e concordo plenamente, ou seja, aquelas que permitem verificar se os respondentes acreditam que haja alguma barreira no processo de transferência de conhecimento.

A partir disso, buscou-se analisar e comparar as barreiras à transferência de conhecimento, das unidades adquiridas e oriundas de greenfield, nos dois sentidos: matriz para subsidiária e da subsidiária para matriz e demais subsidiárias.

Neste estudo foram analisados oito fatores que podem dificultar a transferência de conhecimento entre a matriz e a subsidiária, sendo alguns mais comportamentais e outros mais estruturais, decorrentes dos próprios mecanismos de transferência de conhecimento: resistência cultural, rotatividade de funcionários, não valorização das atividades, demanda de recursos, perda de controle, falta de incentivos, estrutura hierárquica e a síndrome do "não inventado aqui".

A Tabela 4 apresenta os resultados obtidos nos questionários das 66 subsidiárias de multinacionais brasileiras respondentes. Observa-se que de uma maneira geral, os percentuais são baixos, indicando que as unidades percebem poucas barreiras na transferência de conhecimento no contexto da multinacional. 
Tabela 4 - Barreiras na transferência de conhecimento nas multinacionais brasileiras

\begin{tabular}{|c|c|c|c|c|c|c|}
\hline \multirow[t]{2}{*}{$\begin{array}{l}\text { Principais Barreiras na Transferência de } \\
\text { Conhecimento }\end{array}$} & \multicolumn{3}{|c|}{ Matriz para Subsidiária } & \multicolumn{3}{|c|}{ Subsidiária para Matriz } \\
\hline & greenfield & aquisição & Geral & greenfield & aquisição & Geral \\
\hline Resistência da cultura organizacional & $12,0 \%$ & $31,3 \%$ & $19,7 \%$ & $20,0 \%$ & $37,5 \%$ & $31,8 \%$ \\
\hline Turnover dos empregados-chave & $4,0 \%$ & $18,8 \%$ & $10,6 \%$ & $12,0 \%$ & $12,5 \%$ & $10,6 \%$ \\
\hline Crença de que a atividade não era importante & $8,0 \%$ & $15,6 \%$ & $10,6 \%$ & $4,0 \%$ & $3,1 \%$ & $6,1 \%$ \\
\hline recursos & $12,0 \%$ & $9,4 \%$ & $9,1 \%$ & $8,0 \%$ & $9,4 \%$ & $9,1 \%$ \\
\hline $\begin{array}{l}\text { Receio de perder o poder do controle daquela } \\
\text { atividade }\end{array}$ & $12,0 \%$ & $15,6 \%$ & $13,6 \%$ & $0,0 \%$ & $12,5 \%$ & $6,1 \%$ \\
\hline Falta de incentivos para o compartilhamento & $16,0 \%$ & $15,6 \%$ & $13,6 \%$ & $16,0 \%$ & $15,6 \%$ & $13,6 \%$ \\
\hline $\begin{array}{l}\text { Estrutura hierárquica levou a distorções na } \\
\text { transmissão da atividade }\end{array}$ & $12,0 \%$ & $21,9 \%$ & $16,7 \%$ & $12,0 \%$ & $15,6 \%$ & $13,6 \%$ \\
\hline Síndrome do "não inventado aqui" & $12,0 \%$ & $18,8 \%$ & $13,6 \%$ & $12,0 \%$ & $21,9 \%$ & $16,7 \%$ \\
\hline
\end{tabular}

Em relação à dificuldade para integrar e aplicar as atividades devido à resistência da cultura organizacional observa-se que, apesar do baixo percentual de concordância, esta barreira foi a mais evidente $(19,7 \%)$ nos fluxos da matriz para a subsidiária. No entanto, 31,8\% das subsidiárias percebem a resistência cultural nas matrizes quando o conhecimento é oriundo na unidade internacional, principalmente aquelas provenientes de processos de aquisição (37,5\%). Neste caso, as barreiras culturais podem estar associadas ao estilo de gestão das matrizes em relação às subsidiárias.

Outra barreira identificada na transferência de conhecimento entre a matriz e as subsidiárias é a rotatividade dos funcionários responsáveis por tal processo. No entanto, para a amostra estudada, esta barreira é quase inexistente visto que 10,6\% dos respondentes acreditam que ela ocorra, não havendo diferença entre as unidades adquiridas e as greenfield quando o fluxo ocorre da subsidiária para a matriz. Ao se analisar as barreiras no sentido da matriz para a subsidiária, $18,8 \%$ das unidades provenientes de processos de aquisição identificam a existência desta barreira. De certo, neste tipo de processo, podem ocorrer mudanças no quadro de colaboradores locais, impactando negativamente na transferência de conhecimento entre as unidades.

A importância das atividades desenvolvidas e, principalmente no seu compartilhamento, não é uma barreira muito representativa, porque somente $10,6 \%$ dos respondentes no geral, percebem tal existência no fluxo da matriz para a subsidiária, contrapondo-se aos $6,1 \%$ do sentido contrário. Ou seja, nestes poucos casos, as subsidiárias percebem que a matriz não valoriza as atividades e por isso, acaba não as transferindo por achar que estas não originam 
melhorias de eficiências para a corporação. Novamente, cabe destacar o caso das unidades adquiridas, que reconhecem certa resistência (15,6\% de concordância) por parte da matriz quando o fluxo ocorre desta para as unidades.

A necessidade de alocação de tempo, pessoal e recursos entre as unidades das multinacionais brasileiras para o compartilhamento de atividades não se caracterizou como obstáculo para a maioria dos respondentes, sendo que somente $9,1 \%$ acreditam na sua ocorrência.

Ressalta-se, no entanto, que no caso das subsidiárias de greenfield a percepção da barreira é mais acentuada no sentido da matriz para a subsidiária (12\%), justificada pelo fato do próprio investimento direto já demandar alocação de tempo, pessoas e recursos.

Dentre as barreiras, Gupta e Govindarajam (2000) destacam a disposição motivacional para compartilhar conhecimento tanto da matriz quanto da subsidiária, quando não há disposição em transmitir conhecimentos com o receio de perder controle sobre as atividades. Considerando a amostra estudada, 13,6\% das subsidiárias respondentes acreditam que a matriz tenha receio em perder o controle da atividade e, por isso, o compartilhamento de muitas informações e atividades pode ser prejudicado.

É relevante salientar que esta questão do receio em perder o controle da atividade é mais presente no caso dos processos da matriz para a subsidiária, nos dois casos: greenfield (12\%) e aquisição $(15,6 \%)$. No sentido oposto, ou seja, da subsidiária para a matriz, somente as subsidiárias decorrentes de processos de aquisição (12,5\%) reconhecem este apreensão.

Os resultados demonstram que as subsidiárias admitem que faltam incentivos para o compartilhamento de conhecimentos entre as unidades, tanto nas subsidiárias greenfield $(16 \%)$ quanto nas adquiridas $(15,6 \%)$, em ambos os sentidos.

Outra barreira à transferência de conhecimento é decorrente da própria estrutura organizacional, que pode gerar entraves ou distorções no processo. Em relação a este último, as subsidiárias acreditam que a estrutura hierárquica é uma barreira mais expressiva da matriz para a subsidiária $(16,7 \%)$ do que no sentido contrário $(13,6 \%)$. Ressalta-se que esta barreira aparece mais presente para as subsidiárias provenientes de aquisições, principalmente no processo de transferência de conhecimento da matriz para a subsidiária $(21,9 \%)$. Isto denota que ao mesmo tempo em que a matriz busca implementar seus processos na unidade adquirida, o modelo de gestão pode se caracterizar como barreira ao processo. 
A síndrome do "não inventado aqui" é outra disposição motivacional para o compartilhamento do conhecimento, que segundo Gupta e Govindarajam (2000) acontece quando a matriz ou as subsidiárias criam uma barreira em aceitar ideias e conhecimentos gerados em outra unidade.

Em relação aos resultados deste estudo, 16,7\% das respondentes acreditam que a matriz e outras unidades tenham forte relutância em aceitar a atividade criada pelas suas subsidiárias. Esta situação torna-se mais relevante para as subsidiárias provenientes de aquisições $(21,9 \%)$.

Cabe salientar, no entanto, que 13,6\% das subsidiárias respondentes acreditam que exista resistência por parte das unidades em aceitar ideias originadas na matriz ou em outras unidades, sendo novamente mais expressivo, no caso das adquiridas $(18,8 \%)$ do que nas greenfield (12\%).

Logo, para a amostra estudada, percebe-se que as barreiras de transferência de conhecimento entre as unidades nas multinacionais brasileiras existem, mas não são tão expressivas ao ponto de impedirem o compartilhamento de informações e práticas entre as unidades.

\subsubsection{1 - Síntese sobre as barreiras à transferência de conhecimento}

Nas multinacionais brasileiras, as barreiras à transferência de conhecimento existem de forma branda, sendo mais evidentes no caso das subsidiárias adquiridas do que nas de greenfield.

A realidade organizacional nas pesquisas acadêmicas, na área de negócios internacionais, tem mostrado que o processo de aquisição de uma empresa por outra em um mesmo país proporciona dificuldades, decorrentes de choques culturais e barreiras estruturais e comportamentais. Esta situação é agravada quando se analisa situações que envolvem diferentes empresas, em diferentes países, com diferentes culturas, como é o caso de subsidiárias adquiridas por multinacionais brasileiras.

Assim, a resistência cultural é a barreira mais eminente no processo de transferência de conhecimento das multinacionais brasileiras, sendo percebida de forma mais evidente quando este é transferido da subsidiária para a matriz, indicando que as unidades percebem certa dificuldade para integrar e aplicar as atividades no contexto internacional. 
$\mathrm{Na}$ perspectiva da matriz para subsidiária, além da resistência cultural, a estrutura hierárquica aparece como uma barreira à transferência de conhecimento, principalmente quando este ocorre para unidades de aquisição. O fato de as organizações brasileiras apresentarem estrutura burocrática, com alta formalização, especialização e centralização, é uma possível justificativa para a existência de barreiras (NONAKA; TAKEUCHI, 1995), principalmente no processo de criação do conhecimento pelas subsidiárias (ANG; MASSINGHAM, 2007).

No caso das unidades greenfield, a barreira predominante no processo de transferência da matriz para a subsidiária é a falta de incentivos para o compartilhamento de conhecimentos. Isto indica que a matriz não cria mecanismos que incentivem o compartilhamento de práticas, apontando, de certa forma, que o conhecimento da subsidiária greenfield não é relevante ou valorizado para o negócio. Contrapondo-se assim a proposta de Gupta e Govindarajan (2000), na qual deve existir um sistema de incentivo vinculado à gestão do conhecimento entre as unidades, que mobilize estas a otimizarem e realizarem os processos de compartilhamento e valorize o conhecimento no contexto da multinacional.

Entretanto, no processo de transferência de conhecimento da subsidiária para a matriz, além da resistência cultural, nas unidades greenfield novamente a falta de incentivos para o compartilhamento de conhecimentos é uma das barreiras mais presentes, enquanto nas subsidiárias provenientes de aquisições, a síndrome do "não inventado aqui” é mais expressiva.

Nessa última barreira, a percepção das subsidiárias brasileiras é que a matriz cria, mesmo de forma inconsciente, uma barreira em aceitar ideias e conhecimentos gerados nas unidades. Esta disposição motivacional da unidade de destino do conhecimento, a matriz brasileira, pode ser explicada como sendo um mecanismo de autodefesa ou decorrente de lutas de poder (GUPTA; GOVINDARAJAM, 2000). No primeiro caso, os próprios gestores da matriz bloqueiam qualquer conhecimento que indique que as unidades possam parecer mais competentes; no segundo caso, os gerentes buscam desqualificar as subsidiárias, mostrando que o estoque de conhecimento destas não é exclusivo e importante para o negócio da multinacional. 
O Quadro 23 apresenta uma síntese das principais barreiras existentes na transferência de conhecimento entre a matriz e as unidades das multinacionais brasileiras, em ordem de relevância.

Quadro 23 - Síntese das principais barreiras à transferência de conhecimento

\begin{tabular}{|c|l|l|}
\hline & \multicolumn{1}{|c|}{ Matriz para Subsidiária } & \multicolumn{1}{c|}{ Subsidiária para Matriz } \\
\hline \multirow{2}{*}{ Aquisição } & 1- resistência cultural & 1- resistência cultural \\
& 2- estrutura hierárquica & 2- síndrome do "não inventado aqui" \\
\hline \multirow{3}{*}{ Greenfield } & $\begin{array}{l}\text { 1- falta de incentivos para o } \\
\text { compartilhamento de conhecimentos } \\
\text { 2- resistência cultural }\end{array}$ & $\begin{array}{l}\text { 1- resistência cultural } \\
\text { 2- falta de incentivos para o compartilhamento } \\
\text { de conhecimentos }\end{array}$ \\
\hline \multirow{2}{*}{ Geral } & $\begin{array}{l}\text { 1- resistência cultural } \\
\text { 2- estrutura hierárquica }\end{array}$ & $\begin{array}{l}\text { 1- resistência cultural } \\
\text { 2- síndrome do "não inventado aqui" }\end{array}$ \\
\hline
\end{tabular}

Logo, apesar das barreiras de transferência do conhecimento nas multinacionais brasileiras não serem tão expressivas, existem. Assim, demandam atenção por parte das multinacionais brasileiras, que devem buscar minimizar ou erradicar tais barreiras, tornando o processo de transferência de mais eficaz e eficiente.

\section{2 - Características da cultura da subsidiária}

A análise dos aspectos culturais das subsidiárias partiu das quinze afirmativas existentes no questionário, como resultado de fragmentos do instrumento de pesquisa validado por Hofstede (2001), cujo objetivo inicial era identificar valores pessoais sobre ambientes de trabalho. Com estas questões, buscou-se explorar a existência, no âmbito das subsidiárias brasileiras, das quatro dimensões principais propostas pelo autor: distância do poder, masculinidade, individualismo e controle da incerteza.

Cabe salientar que a proposta não era a de analisar profundamente a cultura da subsidiária, mas evidenciar algumas características importantes para a gestão no contexto internacional. Para analisar profundamente a cultura organizacional, outros métodos e técnicas preferencialmente qualitativas devem ser considerados, os quais não foram usados neste estudo, por não fazerem parte do enfoque.

Com o intuito de melhor comparar as respostas obtidas neste estudo dessas dimensões com os dados sobre a realidade brasileira, as subsidiárias foram organizadas em grupos que emergiram dos escores das quatro dimensões de cultura proposta por Hofstede (2001) para 
cada um dos países sedes das unidades. A partir da identificação dos conglomerados, utilizouse a estatística descritiva para comparação dos resultados entre si.

Desta maneira, esta seção está estruturada em três partes: a técnica estatística de conglomerados para a formação dos grupos de subsidiárias; a análise estatística dos dados coletados nesta pesquisa para cada dimensão, comparando-se as características culturais destes conglomerados com as características do Brasil e, por fim, apresenta-se uma síntese dos resultados evidenciados sobre a cultura.

\subsection{1 - Formação e caracterização dos conglomerados de cultura nacional}

Inicialmente, visando compreender se existem diferenças entre os aspectos culturais dos países sedes das subsidiárias em relação ao Brasil, elencou-se todos os países existentes na amostra de análise (22 países), acrescentando-se o Brasil e identificou-se os valores estabelecidos pelo Hofstede (2001) para as quatro dimensões da cultura, conforme demonstrado no ANEXO B.

Apesar de existirem algumas classificações dos países, em relação às dimensões culturais (RONEN e SHENKAR, 1985; INGLEHART, 1997; LEITE, 1981), para o presente estudo optou-se pela identificação de conglomerados a partir das quatro dimensões propostas por Hofstede (2001) para os 22 países existentes na amostra e o Brasil.

Para tanto, utilizou-se a técnica estatística de conglomerados hierárquicos, sendo a distância quadrática euclidiana, a medida de distância utilizada e, entre grupos (between-groups) o método de aglomeração, que prioriza a menor média das distâncias entre todos os pares.

Dentre os resultados encontrados (Apêndice 3), o estágio 20 foi o escolhido, o qual representa três conglomerados. A partir deste resultado, processou-se o k-médias ( $k$-means) para três conglomerados, com 100 interações, que permitiu um refinamento dos mesmos e uma análise mais detalhada dos resultados.

A Tabela 5 apresenta os valores finais encontrados para cada dimensão da cultura nos três conglomerados e os respectivos escores das dimensões para o Brasil. Observa-se que o conglomerado 1 apresenta média distância do poder, alto individualismo e médias masculinidade e controle de incerteza. É formado pelos Estados Unidos, Canadá, Alemanha, Itália e África do Sul. 
Tabela 5 - Valores finais das dimensões nos conglomerados

\begin{tabular}{l|c|c|c|c}
\hline \multirow{2}{*}{} & \multirow{2}{*}{ Brasil } & \multicolumn{3}{|c}{ Cluster } \\
\cline { 3 - 5 } & & 1 & 2 & 3 \\
\hline DP & 69 & 42,60 & 68,44 & 92,00 \\
IND & 38 & 75,80 & 29,19 & 36,00 \\
MAS & 49 & 62,60 & 50,13 & 88,00 \\
INC & 76 & 56,60 & 79,00 & 40,50 \\
\hline
\end{tabular}

O conglomerado 2, representado por Portugal, Espanha, Emirados Árabes e pelos países da América Latina, incluindo o Brasil, apresenta como características predominantes: alto níveis de distância do poder, coletivismo (baixo individualismo) e controle de incerteza e índice neutro de masculinidade.

Entretanto, o conglomerado 3, formado pela China e Eslováquia, apresenta altíssimo valor para a distância de poder e para a masculinidade e, coletivismo e médio valor para o controle sobre as incertezas. Uma possível explicação para a configuração deste conglomerado está na questão político-administrativa, pois enquanto a China ainda apresenta um modelo de governo comunista, a Eslováquia, apesar de não mais tê-lo, ainda guarda resquícios do histórico desta prática governamental.

A análise da técnica de conglomerados é reforçada pelos resultados da análise de variância ANOVA aplicada sobre a amostra. Observa-se que a distribuição F (Tabela 6) calculada para a dimensão distância de poder apresentou o maior valor $(23,595)$, o que a distingue como a variável que mais contribuiu para a formação dos conglomerados. No entanto, a masculinidade foi a que menos contribuiu com distribuição F igual a 7,697.

Tabela 6 - Análise da variância referente aos conglomerados de cultura

\begin{tabular}{l|r|r|r|r|r|r}
\hline & \multicolumn{2}{|c|}{ Cluster } & \multicolumn{2}{c}{ Error } & \multirow{2}{*}{ Sig. } \\
\cline { 2 - 5 } & Mean Square & df & Mean Square & DF & \multicolumn{1}{c}{ F } & \multicolumn{1}{c}{ S } \\
\hline DP & 2077,736 & 2 & 88,057 & 20 & 23,595 &, 000 \\
IND & 4155,294 & 2 & 263,862 & 20 & 15,748 &, 003 \\
MAS & 1408,829 & 2 & 183,048 & 20 & 7,697 &, 001 \\
INC & 1960,107 & 2 & 195,885 & 20 & 10,006 &, \\
\hline
\end{tabular}

Outro aspecto verificado foi o nível de significância das variáveis. Como as quatro variáveis apresentaram nível de significância menor do que 0,05 , não houve necessidade de reprocessar os dados. 
Por fim, para atingir o objetivo específico de identificar características da cultura das subsidiárias, alocou-se cada uma das 66 unidades estrangeiras em um dos três conglomerados acima definidos, conforme o país em que estão localizadas.

Por meio da Tabela 7 observa-se que o conglomerado dois, com aspectos culturais semelhantes aos do Brasil, engloba $67 \%$ das subsidiárias estudadas, seguido pelo conglomerado 1 (26\%), representado predominantemente por países desenvolvidos. As unidades alocadas na China e Eslováquia formaram o conglomerado 3, com $8 \%$ do total de unidades estrangeiras.

Tabela 7 - Distribuição das subsidiárias por conglomerado

\begin{tabular}{c|c|c|c}
\hline Conglomerado & Subsidiárias & \% & Caracterização \\
\hline 1 & 17 & 26 & Países desenvolvidos \\
\hline 2 & 44 & 67 & $\begin{array}{c}\text { América e Europa Latina (países } \\
\text { culturalmente semelhantes ao Brasil) }\end{array}$ \\
\hline 3 & 5 & 8 & $\begin{array}{c}\text { Países com características } \\
\text { comunista/socialista }\end{array}$ \\
\hline Total & $\mathbf{6 6}$ & $\mathbf{1 0 0}$ & \\
\hline
\end{tabular}

Para melhor compreensão e exploração dos dados, os resultados são apresentados separadamente por dimensão: distância do poder, individualismo, masculinidade e controle de incertezas.

Conforme colocado no capítulo da metodologia, foram consideradas as frequências das afirmativas (variável), sendo que para cada uma destas, o respondente tinha cinco opções, de (1) discordo plenamente até (5) concordo plenamente. No entanto, para melhor exploração dos resultados em relação à cultura das subsidiárias, reduziu-se as cinco possibilidades de respostas em relação às afirmativas em três para análise: concordo (totalizando as respostas concordo plenamente e concordo na maioria das vezes), discordo (totalizando as respostas discordo plenamente e discordo na maioria das vezes) e às vezes concordo e às vezes discordo.

\subsection{2 - Análise sobre a dimensão distância do poder}

Segundo Hofstede (2005), a distância do poder representa a percepção do grau de desigualdade entre aquele que detém o poder e aquele que se vê submetido. As subsidiárias responderam quatro afirmativas referentes à distância do poder, conforme a Tabela 8. 
Tabela 8 - Resultados referentes à dimensão distância do poder

\begin{tabular}{|c|c|c|c|c|c|}
\hline \multirow{2}{*}{ Afirmativas } & \multirow[t]{2}{*}{ Resposta } & \multicolumn{3}{|c|}{ Conglomerados } & \multirow[b]{2}{*}{ Geral } \\
\hline & & 1 & 2 & 3 & \\
\hline \multirow{3}{*}{$\begin{array}{l}\text { No dia-dia do trabalho todas as pessoas têm } \\
\text { suas funções e responsabilidades muito bem } \\
\text { definidas }\end{array}$} & negativa & $0,0 \%$ & $7,1 \%$ & $20,0 \%$ & $6,3 \%$ \\
\hline & indiferente & $17,6 \%$ & $16,7 \%$ & $0,0 \%$ & $15,6 \%$ \\
\hline & positiva & $82,4 \%$ & $76,2 \%$ & $80,0 \%$ & $78,1 \%$ \\
\hline \multirow{3}{*}{$\begin{array}{l}\text { No dia-dia do trabalho os superiores têm total } \\
\text { autoridade e respeito na determinação das } \\
\text { atividades dos seus subordinados }\end{array}$} & negativa & $0,0 \%$ & $9,5 \%$ & $0,0 \%$ & $6,3 \%$ \\
\hline & indiferente & $17,6 \%$ & $4,8 \%$ & $20,0 \%$ & $9,4 \%$ \\
\hline & positiva & $82,4 \%$ & $85,7 \%$ & $80,0 \%$ & $84,4 \%$ \\
\hline \multirow{3}{*}{$\begin{array}{l}\text { Os subordinados aceitam as atividades e } \\
\text { responsabilidades que o superior determina }\end{array}$} & negativa & $5,9 \%$ & $2,4 \%$ & $0,0 \%$ & $3,1 \%$ \\
\hline & indiferente & $17,6 \%$ & $16,7 \%$ & $0,0 \%$ & $15,6 \%$ \\
\hline & positiva & $76,5 \%$ & $81,0 \%$ & $100,0 \%$ & $81,3 \%$ \\
\hline \multirow{3}{*}{$\begin{array}{l}\text { As pessoas na organização acreditam que a } \\
\text { maneira de mudar as políticas internas da } \\
\text { organização é pela substituição das pessoas } \\
\text { que estão no poder }\end{array}$} & negativa & $52,9 \%$ & $61,0 \%$ & $50,0 \%$ & $58,1 \%$ \\
\hline & indiferente & $29,4 \%$ & $24,4 \%$ & $50,0 \%$ & $27,4 \%$ \\
\hline & positiva & $17,6 \%$ & $14,6 \%$ & $0,0 \%$ & $14,5 \%$ \\
\hline
\end{tabular}

$\mathrm{O}$ fato de as pessoas possuírem suas atividades e responsabilidades bem definidas representa uma organização com alta amplitude na estrutura hierárquica, a qual reflete a existência de desigualdade entre os níveis mais altos e mais baixos do organograma. Esta é uma característica dos países com alto índice de distância do poder, como o Brasil e os demais países da América Latina, caracterizados pelo conglomerado 2. No entanto, 78,1\% das subsidiárias da amostra acreditam que os indivíduos reconhecem suas funções e responsabilidades claramente nas unidades, o que impede muitas vezes que desenvolvam outras atribuições, pois que ficam "amarrados” àquelas pertinentes ao seu cargo.

Cabe destacar que o percentual de concordância com esta afirmativa também foi alto $(82,4 \%)$ para o conglomerado 1, compreendido por países com baixo índice de distância do poder, segundo estudo do Hofstede (2005). Isto pode representar uma influência das características culturais brasileiras e do estilo de gestão, identificado pela alta distância do poder. Desta maneira, à medida em que a multinacional brasileira empenha-se em implantar seu modelo de gestão nas unidades, muitas vezes com a presença de expatriados brasileiros, formas de trabalho existentes na matriz tendem a ser replicadas, especialmente por estes.

Segundo Hofstede (2005), nos países com alto índice de distância do poder, as organizações caracterizam-se pela centralização de poder em poucas pessoas e, assim, os subordinados esperam que seja dito o que precisam fazer. Em relação à postura dos superiores e subordinados no ambiente de trabalho, percebe-se que $84,4 \%$ das subsidiárias respondentes acreditam que os superiores têm total autoridade na determinação das tarefas dos 
subordinados e, que estes aceitam as atividades e responsabilidades determinadas por aqueles, de acordo com $81,3 \%$ dos respondentes.

Esse resultado seria previsível no caso dos conglomerados 2 e 3, mas não no conglomerado 1, formado por subsidiárias alocadas em países predominantemente com baixo índice de distância do poder. Novamente, surgem indícios de influências da alta hierarquia e da concentração do poder, características culturais e de estilo de gestão brasileira, no processo operacional das subsidiárias estrangeiras.

É notável o resultado de $100 \%$ apresentado no conglomerado 3. Isto corrobora com a teoria de Hofstede (2005), a qual indica que altíssimos valores para a distância do poder é característico de sociedades com histórico político-administrativo similares aos da China e Eslováquia.

Outro aspecto das organizações com alta distância do poder é o fato de as pessoas acreditarem que as mudanças ocorrem quando os funcionários que ocupam a alta direção são substituídos, ou seja, por processos radicais; enquanto nas organizações com baixa distância do poder, a crença é que as mudanças ocorrem gradualmente, a partir de discussões e debates.

Contrapondo-se à teoria, os resultados apontaram que 58,1\% das unidades respondentes discordam que a maneira de mudar as políticas internas da organização é pela substituição das pessoas que estão no poder. É interessante destacar que os conglomerados 2 e 3, com valores altos para a distância do poder, justificaria um elevado percentual de concordância com a afirmativa, diferente do obtido na pesquisa. Para compreender tal ocorrência, neste caso, seria necessário um estudo mais aprofundado da realidade, utilizando-se uma abordagem qualitativa de pesquisa.

Logo, em relação à distância de poder, pode-se observar que há uniformidade nas respostas obtidas nos três conglomerados, se consideradas as três primeiras afirmativas, o que indica uma tendência em serem os aspectos da cultura organizacional da multinacional brasileira e o respectivo modelo de gestão da matriz mais impactantes que a própria cultura nacional do país onde a subsidiária está alocada. 


\subsection{3 - Análise sobre a dimensão individualismo}

O individualismo é caracterizado pela cultura na qual as pessoas se preocupam apenas consigo mesmas e com o seu núcleo familiar, enquanto no coletivismo, as pessoas pertencem a grupos fortes (família, comunidade ou organizações), cujo benefício espera-se que favoreça a todos, com alto grau de lealdade. Para este estudo, considerou-se as três afirmativas respondidas pelas subsidiárias, conforme a Tabela 9.

Tabela 9 - Resultados referentes à dimensão individualismo

\begin{tabular}{|c|c|c|c|c|c|}
\hline \multirow[t]{2}{*}{ Afirmativas } & \multirow[t]{2}{*}{ Respostas } & \multicolumn{3}{|c|}{ Conglomerados } & \multirow{2}{*}{ Geral } \\
\hline & & 1 & 2 & 3 & \\
\hline \multirow{3}{*}{$\begin{array}{l}\text { As pessoas enxergam a possibilidade de } \\
\text { promoção baseada nos anos de experiência do } \\
\text { empregado como um todo e do empregado na } \\
\text { empresa }\end{array}$} & Negativa & $18,8 \%$ & $22,0 \%$ & $40,0 \%$ & $22,6 \%$ \\
\hline & indiferente & $12,5 \%$ & $39,0 \%$ & $20,0 \%$ & $30,6 \%$ \\
\hline & Positiva & $68,8 \%$ & $39,0 \%$ & $50,0 \%$ & $46,8 \%$ \\
\hline \multirow{3}{*}{$\begin{array}{l}\text { É normal a pratica de um superior conceder } \\
\text { emprego para um de seus familiares }\end{array}$} & Negativa & $88,2 \%$ & $85,7 \%$ & $80,0 \%$ & $85,9 \%$ \\
\hline & indiferente & $5,9 \%$ & $9,5 \%$ & $20,0 \%$ & $9,4 \%$ \\
\hline & Positiva & $5,9 \%$ & $4,8 \%$ & $0,0 \%$ & $4,7 \%$ \\
\hline \multirow{3}{*}{$\begin{array}{l}\text { As pessoas no ambiente de trabalho são } \\
\text { incentivadas, sobretudo, por metas e } \\
\text { resultados }\end{array}$} & Negativa & $17,6 \%$ & $9,5 \%$ & $20,0 \%$ & $12,5 \%$ \\
\hline & indiferente & $17,6 \%$ & $4,8 \%$ & $0,0 \%$ & $7,8 \%$ \\
\hline & Positiva & $64,7 \%$ & $85,7 \%$ & $80,0 \%$ & $79,7 \%$ \\
\hline
\end{tabular}

Nas sociedades individualistas, promoções ocorrem por conta das competências dos indivíduos e das regras organizacionais; enquanto nas sociedades coletivistas, privilegia-se o tempo e a experiência dos funcionários na empresa. Os resultados da pesquisa demonstram que $46,8 \%$ das subsidiárias respondentes possuem uma visão coletivista, contrapondo-se aos $22,6 \%$ com percepções individualistas.

Embora a promoção pelo tempo de casa seja uma característica dos países mais coletivistas, ou seja, dos conglomerados 2 e 3, as subsidiárias alocadas nos países componentes do conglomerado 1 (individualistas) acreditam (68,8\%) que exista um favorecimento aos profissionais com mais tempo de trabalho na organização. Isto pode ser reflexo do favorecimento e promoção de profissionais brasileiros (expatriados), pelo fato de pertencerem ao quadro da corporação como um todo há mais tempo do que os funcionários locais.

Em relação à concessão de empregos a familiares, prática de sociedades coletivistas, os resultados apontam que esta ação não é corrente na maioria das subsidiárias (85,9 \%). Uma possível justificativa para a não ocorrência desta prática, principalmente em países coletivistas 
(conglomerados 2 e 3), é que as subsidiárias encontram-se em outros países, na sua maioria distantes do Brasil, o que dificulta, em muito, tais favorecimentos a familiares e amigos brasileiros.

No ambiente organizacional, Hofstede (2005), baseando-se nos conceitos de motivação intrínsecas e extrínsecas, originadas em 1950, dos estudos do psicólogo Herzberg, identificou que nas sociedades individualistas, as pessoas valorizam condições ambientais e materiais, caracterizado pela busca incessante por metas e ganhos financeiros. Enquanto, nas sociedades coletivistas, as pessoas tendem a trabalhar em grupos, em assumir responsabilidades conjuntamente.

Os resultados obtidos nas subsidiárias brasileiras indicam que a percepção geral dos respondentes condiz com um contexto mais individualista, em que as pessoas são incentivadas por metas e resultados individuais $(79,7 \%)$. É curioso que o conglomerado 1 , formado por países individualistas, foi o que apresentou menor convicção com relação a esta afirmativa $(64,7 \%)$. Uma possível explicação para tal ocorrência é o fato de muitos questionários terem sido respondidos por executivos expatriados brasileiros, os quais podem ter explicitado seus valores pessoais, ao invés dos locais.

Assim, em relação ao individualismo, observou-se que não houve uma uniformidade nas respostas, ou seja, dependendo da afirmativa enunciada e do conglomerado, os resultados indicam uma visão mais individualista, enquanto em outras, mais coletivista. Para esta dimensão, nem sempre os resultados mostraram uma coerência com os estudos de Hofstede (2005), nem com uma concordância com as características brasileiras, neste caso, coletivista.

\subsection{4 - Análise sobre a dimensão masculinidade}

A dimensão masculinidade representa o quanto os resultados e o sucesso são os valores dominantes na sociedade e o quanto o trabalho é colocado em primeiro lugar. Contrapondo-se a isto, o bem estar e a qualidade de vida das pessoas destacam-se na sociedade feminina, não havendo distinção nos papéis e emoções entre os gêneros.

Entretanto, cabe salientar que a dimensão masculinidade foi a que teve menor representatividade na formação dos conglomerados para análise neste estudo, conforme 
explicitado no início desta seção. Isto é decorrência provavelmente do fato de os valores deste índice, postulados por Hofstede (2005) para todos os países da amostra não serem tão expressivos positiva ou negativamente, ou seja, não apresentarem tantas discrepâncias, indicando que na maioria são culturas sem uma definição clara em qual categoria estão, masculina ou feminina.

Logo, é possível encontrar nas respostas das subsidiárias destes países tanto características das sociedades masculinas quanto das femininas. Para essa dimensão foram exploradas quatro afirmativas do questionário, as quais são apresentadas na Tabela 10.

Tabela 10 - Resultados referentes à dimensão masculinidade

\begin{tabular}{|c|c|c|c|c|c|}
\hline \multirow[t]{2}{*}{ Afirmativas } & \multirow[t]{2}{*}{ Respostas } & \multicolumn{3}{|c|}{ Conglomerados } & \multirow[t]{2}{*}{ Geral } \\
\hline & & 1 & 2 & 3 & \\
\hline \multirow{3}{*}{$\begin{array}{l}\text { As pessoas enxergam a competitividade } \\
\text { interna como um aspecto normal, pois a lei é } \\
\text { "competir ou morrer" }\end{array}$} & negativa & $47,1 \%$ & $45,0 \%$ & $0,0 \%$ & $42,6 \%$ \\
\hline & indiferente & $29,4 \%$ & $40,0 \%$ & $50,0 \%$ & $37,7 \%$ \\
\hline & positiva & $23,5 \%$ & $15,0 \%$ & $50,0 \%$ & $19,7 \%$ \\
\hline \multirow{3}{*}{$\begin{array}{l}\text { Os homens são muito mais orientados para o } \\
\text { sucesso material e as metas financeiras }\end{array}$} & negativa & $17,6 \%$ & $29,3 \%$ & $0,0 \%$ & $23,8 \%$ \\
\hline & indiferente & $35,3 \%$ & $36,6 \%$ & $40,0 \%$ & $36,5 \%$ \\
\hline & positiva & $47,1 \%$ & $34,1 \%$ & $60,0 \%$ & $39,7 \%$ \\
\hline \multirow{3}{*}{$\begin{array}{l}\text { Não é bem visto que as pessoas mostrem suas } \\
\text { emoções em público }\end{array}$} & negativa & $41,2 \%$ & $47,5 \%$ & $20,0 \%$ & $43,5 \%$ \\
\hline & indiferente & $29,4 \%$ & $35,0 \%$ & $20,0 \%$ & $32,3 \%$ \\
\hline & positiva & $29,4 \%$ & $17,5 \%$ & $60,0 \%$ & $24,2 \%$ \\
\hline \multirow{3}{*}{$\begin{array}{l}\text { As pessoas dão importância muito alta para a } \\
\text { titulação do cargo }\end{array}$} & negativa & $35,3 \%$ & $19,0 \%$ & $0,0 \%$ & $21,9 \%$ \\
\hline & indiferente & $23,5 \%$ & $23,8 \%$ & $20,0 \%$ & $23,4 \%$ \\
\hline & positiva & $41,2 \%$ & $57,1 \%$ & $80,0 \%$ & $54,7 \%$ \\
\hline
\end{tabular}

Nas sociedades masculinas, a competitividade é fator predominante. Percebe-se que as subsidiárias dos conglomerados 1 e 2 apresentam uma percepção negativa em relação à competitividade interna $(47,1 \%$ e $45 \%$ respectivamente), indicando uma abordagem mais feminina, apesar de o conglomerado 1 apresentar países com características mais masculinas.

No entanto, os resultados do conglomerado 3 confirmam os dados da pesquisa de Hofstede (2005) para os dois países: Eslováquia e China, ambos masculinos, ou seja, a competição é algo natural em tais sociedades.

Novamente, observa-se que os conglomerados 1 e 3, formados por países masculinos, apresentam resultados expressivos no que diz respeito à orientação ao sucesso material e metas financeiras $(47,1 \%$ e $60,0 \%$ respectivamente). Interessante destacar o percentual de respondentes indiferentes (36,5\% no geral) nos conglomerados, indicando que para muitos países não há uma visão uniforme sobre o sucesso material. 
Em relação à demonstração de emoções em público, nas sociedades masculinas não é permitida. Repetidamente, os dados confirmam os estudos de Hofstede (2005), no que diz respeito aos países do conglomerado 3 , indicando que $60 \%$ das subsidiárias acreditam que a demonstração das emoções em público não é bem vista. Entretanto, para os demais conglomerados, as respostas indicam uma tendência para ambientes mais femininos ou neutros, visto os expressivos números de respostas negativas $(43,5 \%)$ e indiferentes $(32,3 \%)$.

Nos países masculinos, as pessoas valorizam o dinheiro, carreira, desafios e reconhecimento; enquanto nas sociedades femininas a ênfase está na relação de trabalho harmoniosa e o foco na qualidade de vida é maior (HOFSTEDE, 2005). Logo, as subsidiárias do conglomerado 3 reconhecem que a titulação dos cargos na organização é importante (80\%), condizendo com as sociedades masculinas.

Ressalta-se que o percentual de concordância dos respondentes do conglomerado 2 foi expressivo $(57,1 \%)$, considerando-se que os países são predominantemente neutros para a dimensão masculinidade, como o Brasil. Pode-se atribuir este resultado à afirmativa "as pessoas dão importância muito alta para a titulação do cargo" ser também uma característica dos países com alta distância do poder, onde a posição hierárquica é muito valorizada.

Assim, em relação ao índice de masculinidade, os resultados não apontam para uma identificação ou influência direta da cultura brasileira. Provavelmente, pelo Brasil apresentar uma posição neutra em relação a esta dimensão, conforme dados originais de Hofstede, não seja relevante no modelo de gestão brasileiro. Logo, a influência desta característica nas subsidiárias dos demais países não é evidente como a distância do poder.

\subsection{5 - Análise sobre a dimensão controle das incertezas}

O controle das incertezas é a dimensão que representa o quanto as pessoas de uma sociedade sentem-se ameaçadas pela incerteza e ambiguidade e tentam evitar e/ou controlar essas situações.

Para essa dimensão, utilizou-se dos dados oriundos de quatro afirmativas contempladas no questionário respondido pelas subsidiárias (Tabela 11). 
Tabela 11 - Resultados referentes à dimensão controle de incertezas

\begin{tabular}{|c|c|c|c|c|c|}
\hline \multirow{2}{*}{ Afirmativas } & \multirow{2}{*}{ Respostas } & \multicolumn{3}{|c|}{ Conglomerados } & \multirow{2}{*}{ Geral } \\
\hline & & 1 & 2 & 3 & \\
\hline \multirow{3}{*}{$\begin{array}{l}\text { Existem muitas regras que devem ser seguidas } \\
\text { fielmente }\end{array}$} & negativa & $29,4 \%$ & $21,4 \%$ & $0,0 \%$ & $21,9 \%$ \\
\hline & indiferente & $23,5 \%$ & $42,9 \%$ & $40,0 \%$ & $37,5 \%$ \\
\hline & positiva & $47,1 \%$ & $35,7 \%$ & $60,0 \%$ & $40,6 \%$ \\
\hline \multirow{3}{*}{$\begin{array}{l}\text { As pessoas não têm opiniões muito ambíguas } \\
\text { sobre o que é bom ou mal }\end{array}$} & negativa & $29,4 \%$ & $23,8 \%$ & $20,0 \%$ & $25,0 \%$ \\
\hline & indiferente & $29,4 \%$ & $31,0 \%$ & $20,0 \%$ & $29,7 \%$ \\
\hline & positiva & $41,2 \%$ & $45,2 \%$ & $60,0 \%$ & $45,3 \%$ \\
\hline \multirow{3}{*}{$\begin{array}{l}\text { As pessoas dão importância significativa para } \\
\text { a estabilidade dos eventos e cargos }\end{array}$} & negativa & $0,0 \%$ & $10,0 \%$ & $0,0 \%$ & $6,6 \%$ \\
\hline & indiferente & $31,3 \%$ & $17,5 \%$ & $20,0 \%$ & $21,3 \%$ \\
\hline & positiva & $68,8 \%$ & $72,5 \%$ & $80,0 \%$ & $72,1 \%$ \\
\hline \multirow{3}{*}{$\begin{array}{l}\text { As pessoas não gostam de informações } \\
\text { contraditórias }\end{array}$} & negativa & $6,3 \%$ & $12,8 \%$ & $20,0 \%$ & $11,7 \%$ \\
\hline & indiferente & $25,0 \%$ & $23,1 \%$ & $0,0 \%$ & $21,7 \%$ \\
\hline & positiva & $68,8 \%$ & $64,1 \%$ & $80,0 \%$ & $66,7 \%$ \\
\hline
\end{tabular}

Os estudos de Hofstede (2005) apontam que no ambiente de trabalho, nos países com elevado índice de controle das incertezas existem numerosas leis, formais e informais, que controlam os direitos e deveres dos empregados.

Sobre os resultados referentes à percepção dos respondentes se as regras devem ser seguidas fielmente, é interessante destacar que os resultados obtidos não condizem com as expectativas; visto que o conglomerado 2, com valores maiores para a dimensão conforme estudo do Hofstede (2005), apresentou menores concordâncias (35,7\%) se comparado com os demais. Uma justificativa seria o fato de a afirmativa não mencionar o tipo de regra a ser seguida, levando o respondente a pensar somente nas formais, descartando as informais e os “jeitinhos”, típicos do Brasil e demais países latinos, pertencentes a este conglomerado.

Em contrapartida, no conglomerado 3, de quem se esperavam valores baixos, $60 \%$ das unidades respondentes concordaram com a afirmativa, indicando que as regras estabelecidas devem ser seguidas fielmente. Percebe-se, neste caso, que o estilo de gestão brasileiro pode estar impactando nas subsidiárias destes países, por meio da determinação de cumprimento de regras e normas da matriz.

Como forma de lidarem com as situações, os indivíduos de sociedades com alto índice nessa dimensão, buscam proteção em crenças que prometam certezas, rejeitam ideias novas e aceitam a existência de verdades absolutas (HOFSTEDE, 2005). Desta maneira, é possível constatar que $45,3 \%$ dos respondentes acreditam que as pessoas não têm opiniões muito ambíguas sobre o que é bom ou mal, ou seja, de uma maneira geral, os indivíduos são conscientes e seguros sobre os seus pontos de vista. 
Nas sociedades com alto valor para a dimensão de controle de incertezas, os indivíduos tendem a dar importância para a estabilidade, principalmente de cargos e eventos. Desta maneira, os resultados deste estudo corroboram com os dados do Hofstede (2005) para os países pertencentes ao segundo conglomerado (72,5\%), como o Brasil.

É interessante destacar que nos conglomerados 1 e 3 o percentual de concordância com a afirmativa também foi elevado (68,8\% e $80,0 \%$ respectivamente). Uma explicação para tal ocorrência pode ser a interferência direta da matriz nas subsidiárias e até a possibilidade do respondente (representante da unidade) ser brasileiro, demonstrando a sua percepção individual e não propriamente dita a dos demais colaboradores e da sociedade como um todo.

Tanure (2007) ressalta que as culturas com valores altos de controle das incertezas evitam situações ambíguas, pois não toleram conviver com alto grau de incerteza por muito tempo. Sobre este aspecto é interessante destacar que $66,7 \%$ das subsidiárias da amostra indicam que as pessoas não gostam de informações contraditórias, característica predominante em sociedades com alto grau de controle de incertezas, como o Brasil. Cabe salientar, no entanto, que este resultado seria previsível no conglomerado 2, mas ocorreu nos demais, cujos países apresentam valores moderados ou baixo para a referida dimensão, conforme estudo do Hofstede (2001).

Logo, em relação à dimensão controle de incerteza, observa-se que os resultados indicam uma influência das características brasileiras na atuação das subsidiárias.

\subsection{6 - Síntese sobre a cultura}

Os resultados do estudo para as quatro dimensões propostas por Hofstede (2001) - distância do poder, masculinidade, individualismo e controle de incertezas - indicam que algumas são mais expressivas para as subsidiárias do que outras no contexto das multinacionais brasileiras.

Dentre essas dimensões, as mais significativas para o Brasil são a distância do poder e o controle de incertezas, representando altos índices (HOFSTEDE, 2001), muitas vezes percebidas pela alta concentração do poder e estrutura hierárquica tradicional nas organizações brasileiras. 
É interessante ressaltar que essas duas dimensões foram as que apresentaram para as subsidiárias da amostra, de uma maneira geral, resultados semelhantes aos do Brasil, mesmo para aquelas instaladas em países com características culturais diferentes. Desta maneira, acredita-se que as características culturais brasileiras, principalmente no que diz respeito à hierarquia e a centralização, estão presentes nas subsidiárias estudadas.

Em relação ao individualismo, os resultados obtidos com a amostra estudada foram variados em relação às afirmativas e aos conglomerados, ou seja, não houve uma uniformidade nas respostas a ponto de ser possível afirmar semelhança ou diferença com as características brasileiras. Destaca-se que o mesmo aconteceu com a dimensão masculinidade, neutra para o Brasil, cujo os resultados não foram expressivos para a amostra estudada.

Quadro 24 demonstra a síntese das análises obtidas com as afirmativas sobre cultura, explicitando os resultados por dimensão. Para cada dimensão da cultura, indicou-se a classificação do índice do estudo do Hofstede (2001) para o Brasil, os resultados observados com a amostra de subsidiárias e, por fim a constatação ou não da influência do estilo de gestão brasileiro nas unidades.

Quadro 24 - Síntese das análises sobre a cultura

\begin{tabular}{|c|c|c|l|}
\hline $\begin{array}{c}\text { Dimensão da } \\
\text { Cultura }\end{array}$ & $\begin{array}{c}\text { Índice do Hofstede } \\
\text { para o Brasil }\end{array}$ & $\begin{array}{c}\text { Observado nas } \\
\text { Subsidiárias }\end{array}$ & $\begin{array}{c}\text { Influência do estilo de gestão } \\
\text { brasileiro }\end{array}$ \\
\hline Distância do poder & Alta & Alta & - há evidências \\
\hline Individualismo & Baixo & Variado & - não há evidências suficientes \\
\hline Masculinidade & Média (neutralidade) & Média & - não há evidências suficientes \\
\hline $\begin{array}{c}\text { Controle das } \\
\text { incertezas }\end{array}$ & Alta & Média para Alta & - há evidências \\
\hline
\end{tabular}

No processo de internacionalização das empresas brasileiras, por meio de greenfield e de aquisições, as matrizes tendem a replicar seus modelos de gestão às subsidiárias, mesmo de que forma intrínseca, por meio principalmente, de processos de expatriação e outros mecanismos de controle, fazendo com que as unidades apresentem ou tenham que se reportar à matriz constantemente por meio de relatórios ou mesmo em situações de tomada de decisão local.

Entretanto, pelo Brasil ser um país coletivista não parece representar impacto direto na gestão das subsidiárias de multinacionais brasileiras, podendo inclusive facilitar o processo de adaptação e integração entre as unidades. Como nas sociedades coletivistas as pessoas são 
interligadas em redes sociais e tendem a trabalhar em grupos, os brasileiros são mais receptíveis e propiciam um ambiente aberto e descontraído de trabalho; além de o Brasil ser um país multicultural, no qual as pessoas convivem e estão acostumadas com diferentes visões e costumes, o que pode ser um fator facilitador na dinâmica organizacional.

Logo, a análise dos dados sobre cultura indica, que em algumas situações, a cultura do país da matriz, no caso o Brasil, influencia ou está presente no modelo de gestão das subsidiárias, mesmo que de forma involuntária. As multinacionais, ao decidirem o país sede da subsidiária, devem examinar a sua cultura local, elencando aspectos similares e diferentes da cultura de origem, buscando minimizar os conflitos entre as partes.

Cabe salientar, no entanto, que a presença da cultura nacional brasileira nas subsidiárias pode ser decorrente das próprias culturas organizacionais das matrizes (ou multinacionais como um todo), visto que estas, de certa maneira, apresentam aspectos da cultura do país de origem da empresa. Assim, apesar de cada organização ter sua própria cultura, com normas e valores particulares, a cultura nacional é um fator muito relevante e de grande influência na cultura organizacional.

Por fim, cabe mencionar que esta reflexão sobre a cultura no contexto das subsidiárias de multinacionais brasileiras indica e corrobora com a perspectiva divergente em relação à cultura. Enquanto na perspectiva convergente há uma predominância dos modelos de gestão dos países desenvolvidos e que estes seriam utilizados como padrões para os demais países do mundo; na divergente, existem diferenças de modelos de gestão organizacional entre países e regiões, decorrentes de suas culturas nacionais e empresariais, os quais impactam nos processos gerenciais, principalmente na atuação internacional.

\section{3 - A influência da cultura e da transferência de conhecimento na iniciativa da subsidiaria}

Visando analisar a influência da cultura e da transferência de conhecimento na iniciativa da subsidiária, utilizou-se a técnica de modelagem de equações estruturais, a qual permitiu validar o modelo de pesquisa proposto (Ilustração 11), bem como verificar as hipóteses de pesquisa. 
Assim, esta seção está dividida em duas partes, sendo a primeira os resultados da modelagem de equações estruturais a partir dos dados coletados, destacando-se as etapas preconizadas pela técnica. Na segunda parte, os resultados são discutidos à luz do referencial e modelo teórico, aplicado a realidade das subsidiárias de multinacionais brasileiras.

\subsection{1 - Modelagem de equações estruturais}

Como decorrência das três hipóteses delineadas e do modelo proposto, conforme detalhado nos capítulos anteriores, para a aplicação da modelagem de equações estruturais, os construtos e os indicadores reflexivos são detalhados, as quais são explicitadas no Quadro 25.

Quadro 25 - Síntese das hipóteses e variáveis do modelo

\begin{tabular}{|c|c|c|c|}
\hline \multicolumn{2}{|c|}{ Modelo Estrutural } & \multicolumn{2}{|c|}{ Modelo de Mensuração } \\
\hline Hipóteses & Enunciado & $\begin{array}{c}\text { Construtos } \\
\text { (variáveis latentes) }\end{array}$ & Indicadores reflexivos \\
\hline \multirow[b]{2}{*}{ H 1} & \multirow[b]{2}{*}{$\begin{array}{lr}\text { A iniciativa } & \text { da } \\
\text { subsidiária } & \text { é } \\
\text { diretamente } & \\
\text { influenciada } & \text { pela } \\
\text { transferência } & \text { de } \\
\text { conhecimento. } & \end{array}$} & $\begin{array}{l}\text { Iniciativa da subsidiária } \\
\left.\text { ( } 2^{\mathrm{a}} \text { ordem }\right)\end{array}$ & $\begin{array}{l}\text { - Iniciativa externa: REL } 1 \text { ao REL } 12 \\
\text { - Iniciativa interna: RIPOS } 1 \text { ao } 9\end{array}$ \\
\hline & & $\begin{array}{c}\text { Transferência de } \\
\text { conhecimento } \\
\left(3^{\mathrm{a}} \text { ordem }\right)\end{array}$ & $\begin{array}{l}\text { - Transferência de conhecimento da } \\
\text { matriz para subsidiária: K1 a K10 } \\
\text { (mecanismos) e BK 1 a BK } 8 \text { (barreiras) } \\
\text { - Transferência de conhecimento da } \\
\text { subsidiária para matriz: KS1 a KS } 10 \\
\text { (mecanismos) e BKS } 1 \text { a } \\
\text { (barreiras) }\end{array}$ \\
\hline \multirow[t]{2}{*}{ H 2} & \multirow{2}{*}{$\begin{array}{lr}\text { A iniciativa } & \text { da } \\
\text { subsidiária } & \text { é } \\
\text { diretamente } & \\
\text { influenciada } & \text { pela } \\
\text { cultura. } & \end{array}$} & $\begin{array}{l}\text { Iniciativa da subsidiaria } \\
\left.\text { ( } 2^{\mathrm{a}} \text { ordem }\right)\end{array}$ & $\begin{array}{l}\text { - Iniciativa externa: REL } 1 \text { ao REL } 12 \\
\text { - Iniciativa interna: RIPOS } 1 \text { ao } 9\end{array}$ \\
\hline & & Cultura ( $1^{\mathrm{a}}$ ordem $)$ & - HOF 1 ao HOF 15 \\
\hline \multirow[t]{2}{*}{ H 3} & \multirow[t]{2}{*}{$\begin{array}{l}\text { A transferência de } \\
\text { conhecimento é } \\
\text { diretamente } \\
\text { influenciada pela } \\
\text { cultura. }\end{array}$} & $\begin{array}{l}\text { Transferência de } \\
\text { conhecimento } \\
\left(3^{\mathrm{a}} \text { ordem }\right)\end{array}$ & 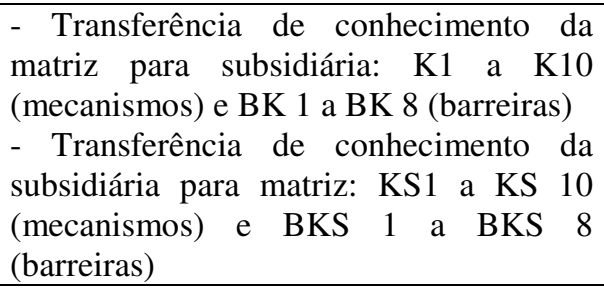 \\
\hline & & Cultura ( $1^{\mathrm{a}}$ ordem $)$ & - HOF 1 ao HOF 15 \\
\hline
\end{tabular}

Cabe salientar que se trata de um modelo reflexivo para todos os construtos (variáveis latentes), ou seja, os indicadores são manifestações dos construtos, sendo esperados que os indicadores se correlacionem (JARVIS; MACKENZIE; PODSAKOFF, 2003), conforme a Ilustração 11. 


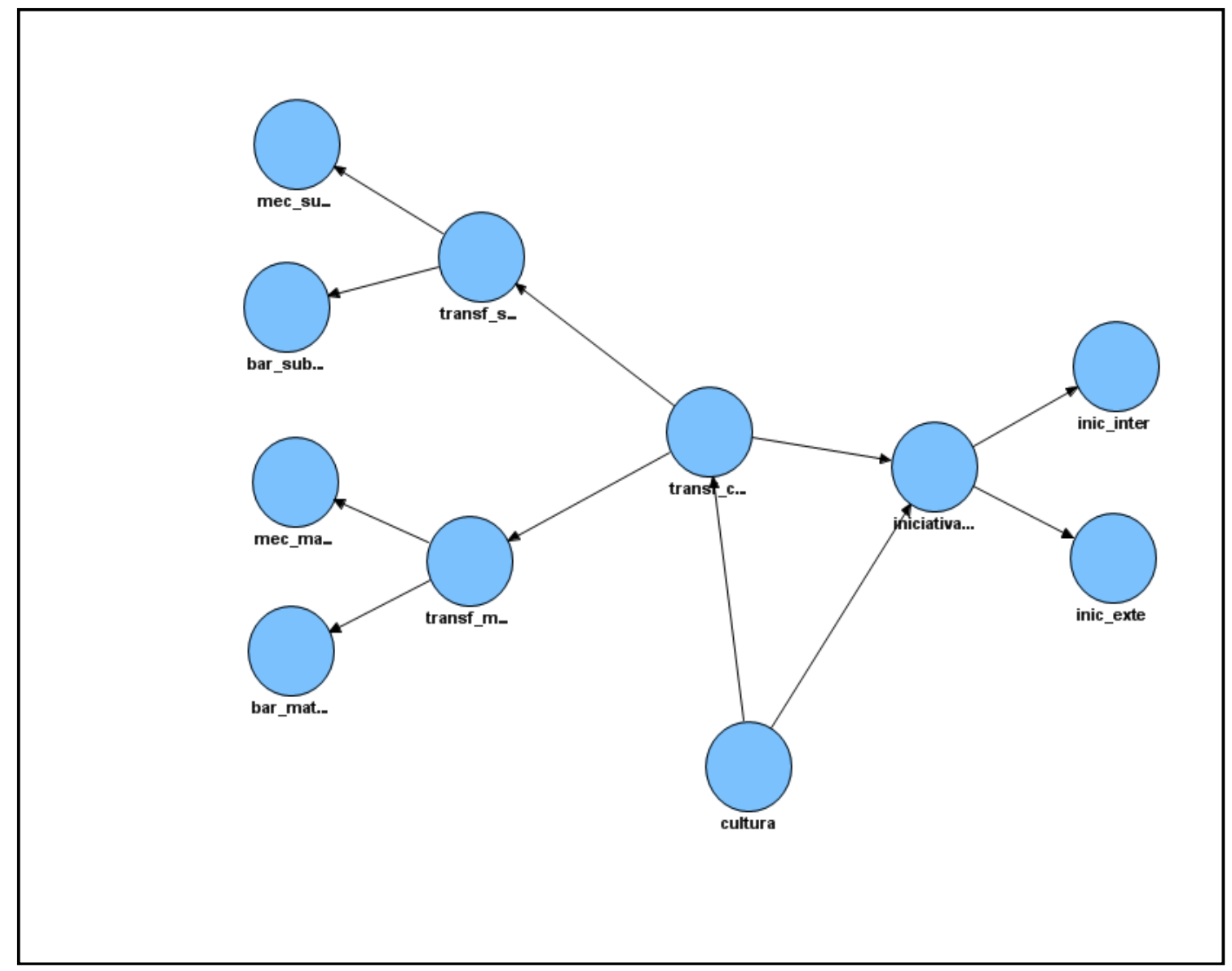

Ilustração 11- Modelo proposto na modelagem de equações estruturais Fonte: Software SmartPLS

Antes do processamento da modelagem de equações estruturais, conforme as recomendações de Wold (1982 apud Zwicker et al, 2008) e Wetzels et al. (2009), alguns cuidados foram tomados tais como a repetição dos indicadores nas variáveis latentes de ordem superior.

Todos os indicadores da variável latente de primeira ordem (por exemplo, no caso de mec_sub, ks1 a ks9) foram também utilizados como indicadores da variável latente de segunda ordem (neste caso, a transferência de conhecimento da subsidiária para a matriz); aplicando-se o mesmo para as variáveis latentes de terceira ordem, como por exemplo, transferência do conhecimento. Assim, as variáveis latentes de primeira ordem são reutilizadas como indicadores reflexivos das variáveis latentes de ordem superior.

Buscando aperfeiçoar o modelo, a cada processamento, no máximo um indicador com carga fatorial inferior a 0,7 foi retirado de cada construto, detalhado na Tabela 12, pois acarreta baixa validade e confiabilidade para o modelo de mensuração. O novo modelo formado é processado, obtendo-se, assim, outros valores para as cargas fatoriais. Este processo foi 
repetido até obter cargas fatoriais aceitáveis, ou seja, valores preferencialmente maiores que 0,7 (FORNELL; LARCKER, 1981; CHIN, 1998) para todas as variáveis. Cabe salientar, no entanto, que cargas menores, de 0,6 ou de 0,7 podem ser aceitas, dependendo dos outros indicadores do construto, como uma forma de manter a validade de conteúdo (LITTLE et al., 1999). 
Tabela 12 - Indicadores retirados do modelo por apresentarem carga fatorial menor que 0,7

\begin{tabular}{|c|c|c|c|c|c|c|c|}
\hline \multirow[b]{2}{*}{ Modelo } & \multicolumn{7}{|c|}{ Construto } \\
\hline & $\begin{array}{c}\text { Mecanismos de } \\
\text { transferência de } \\
\text { conhecimento da } \\
\text { matriz para a } \\
\text { subsidiária (K1 a } \\
\text { K10) }\end{array}$ & $\begin{array}{c}\text { Mecanismos de } \\
\text { transferência de } \\
\text { conhecimento da } \\
\text { subsidiária para a matriz } \\
(\text { KS1 a KS10) }\end{array}$ & $\begin{array}{c}\text { Barreiras na } \\
\text { transferência de } \\
\text { conhecimento da matriz } \\
\text { para a sua subsidiária } \\
\text { (BK1 a BK8) }\end{array}$ & $\begin{array}{c}\text { Barreiras na } \\
\text { transferência de } \\
\text { conhecimento da } \\
\text { subsidiária para a sua } \\
\text { matriz (BKS1 a BKS8) }\end{array}$ & $\begin{array}{l}\text { Cultura } \\
\text { (HOF1 a } \\
\text { HOF15) }\end{array}$ & $\begin{array}{l}\text { Iniciativa } \\
\text { Interna } \\
\text { (RIPOS1 a } \\
\text { RIPOS9) }\end{array}$ & $\begin{array}{c}\text { Iniciativa } \\
\text { Externa } \\
\text { (REL1 a } \\
\text { REL12) }\end{array}$ \\
\hline $\begin{array}{c}1^{\mathrm{a}} \\
\text { estimação }\end{array}$ & $\mathrm{K} 6=0,369$ & $\begin{array}{c}\text { Todas as demais cargas } \\
\text { aprovadas }\end{array}$ & $\begin{array}{c}\text { Todas as demais cargas } \\
\text { aprovadas }\end{array}$ & $\begin{array}{c}\text { Todas as cargas } \\
\text { aprovadas }\end{array}$ & HOF13=0,315 & RIFOS 5=0,400 & REL4=0,593 \\
\hline $\begin{array}{c}2^{\mathrm{a}} \\
\text { estimação }\end{array}$ & $\mathrm{K} 10=0,517$ & $\begin{array}{c}\text { Todas as demais cargas } \\
\text { aprovadas }\end{array}$ & $\begin{array}{c}\text { Todas as demais cargas } \\
\text { aprovadas }\end{array}$ & $\begin{array}{c}\text { Todas as cargas } \\
\text { aprovadas }\end{array}$ & HOF $15=0,332$ & RIPOS $3=0,427$ & REL 3=0,613 \\
\hline $\begin{array}{c}3^{\mathrm{a}} \\
\text { estimação }\end{array}$ & $\mathrm{K} 9=0,540$ & $\begin{array}{c}\text { Todas as demais cargas } \\
\text { aprovadas }\end{array}$ & $\begin{array}{c}\text { Todas as demais cargas } \\
\text { aprovadas }\end{array}$ & $\begin{array}{c}\text { Todas as cargas } \\
\text { aprovadas }\end{array}$ & $\mathrm{HOF} 10=0,442$ & RIPOS6=0,586 & REL1=0,603 \\
\hline $\begin{array}{c}4^{\mathrm{a}} \\
\text { estimação }\end{array}$ & $\begin{array}{l}\text { Todas as demais } \\
\text { cargas aprovadas }\end{array}$ & $\begin{array}{c}\text { Todas as demais cargas } \\
\text { aprovadas }\end{array}$ & $\begin{array}{c}\text { Todas as demais cargas } \\
\text { aprovadas }\end{array}$ & $\begin{array}{c}\text { Todas as cargas } \\
\text { aprovadas }\end{array}$ & HOF7=0,501 & $\begin{array}{c}\text { Todas as cargas } \\
\text { aprovadas }\end{array}$ & REL12=0,616 \\
\hline $\begin{array}{c}5^{\mathrm{a}} \\
\text { estimação }\end{array}$ & $\begin{array}{l}\text { Todas as demais } \\
\text { cargas aprovadas }\end{array}$ & $\begin{array}{c}\text { Todas as demais cargas } \\
\text { aprovadas }\end{array}$ & $\begin{array}{c}\text { Todas as demais cargas } \\
\text { aprovadas }\end{array}$ & $\begin{array}{c}\text { Todas as cargas } \\
\text { aprovadas }\end{array}$ & HOF6=0,477 & $\begin{array}{c}\text { Todas as cargas } \\
\text { aprovadas }\end{array}$ & REL8=0,617 \\
\hline $\begin{array}{c}6^{\mathrm{a}} \\
\text { estimação }\end{array}$ & $\begin{array}{l}\text { Todas as demais } \\
\text { cargas aprovadas }\end{array}$ & $\begin{array}{c}\text { Todas as demais cargas } \\
\text { aprovadas }\end{array}$ & $\begin{array}{c}\text { Todas as demais cargas } \\
\text { aprovadas }\end{array}$ & $\begin{array}{c}\text { Todas as cargas } \\
\text { aprovadas }\end{array}$ & HOF14=0,506 & $\begin{array}{c}\text { Todas as cargas } \\
\text { aprovadas }\end{array}$ & $\begin{array}{c}\text { Todas as cargas } \\
\text { aprovadas }\end{array}$ \\
\hline $\begin{array}{c}7^{\mathrm{a}} \\
\text { estimação }\end{array}$ & $\begin{array}{l}\text { Todas as demais } \\
\text { cargas aprovadas }\end{array}$ & $\begin{array}{c}\text { Todas as demais cargas } \\
\text { aprovadas }\end{array}$ & $\begin{array}{c}\text { Todas as demais cargas } \\
\text { aprovadas }\end{array}$ & $\begin{array}{c}\text { Todas as cargas } \\
\text { aprovadas }\end{array}$ & $\mathrm{HOF} 3=0,524$ & $\begin{array}{c}\text { Todas as cargas } \\
\text { aprovadas }\end{array}$ & $\begin{array}{c}\text { Todas as cargas } \\
\text { aprovadas }\end{array}$ \\
\hline $\begin{array}{c}8^{\mathrm{a}} \\
\text { estimação }\end{array}$ & $\begin{array}{l}\text { Todas as demais } \\
\text { cargas aprovadas }\end{array}$ & $\begin{array}{c}\text { Todas as demais cargas } \\
\text { aprovadas }\end{array}$ & $\begin{array}{c}\text { Todas as demais cargas } \\
\text { aprovadas }\end{array}$ & $\begin{array}{c}\text { Todas as cargas } \\
\text { aprovadas }\end{array}$ & $\mathrm{HOF} 2=0,519$ & $\begin{array}{l}\text { Todas as cargas } \\
\text { aprovadas }\end{array}$ & $\begin{array}{c}\text { Todas as cargas } \\
\text { aprovadas }\end{array}$ \\
\hline $\begin{array}{c}9^{\mathrm{a}} \\
\text { estimação }\end{array}$ & $\begin{array}{l}\text { Todas as demais } \\
\text { cargas aprovadas }\end{array}$ & $\begin{array}{c}\text { Todas as demais cargas } \\
\text { aprovadas }\end{array}$ & $\begin{array}{c}\text { Todas as demais cargas } \\
\text { aprovadas }\end{array}$ & $\begin{array}{l}\text { Todas as cargas } \\
\text { aprovadas }\end{array}$ & $\mathrm{HOF} 1=0,576$ & $\begin{array}{c}\text { Todas as cargas } \\
\text { aprovadas }\end{array}$ & $\begin{array}{c}\text { Todas as cargas } \\
\text { aprovadas }\end{array}$ \\
\hline
\end{tabular}

O modelo final ( $9^{\mathrm{a}}$ estimação) é comentado nas próximas seções e está apresentado de forma completa no Apêndice 4 


\subsubsection{1 - Avaliação do modelo de mensuração}

O modelo de mensuração representa as variáveis latentes (construtos) que são originadas das variáveis ou indicadores reflexivos. Ou seja, por meio deste modelo é possível observar todas as relações existentes entre os construtos e seus respectivos indicadores.

A Ilustração 12 representa o modelo de mensuração final, após a nona estimação. Assim, observa-se que do total de 71 indicadores iniciais, 51 permaneceram. Cabe salientar, conforme detalhado na Tabela 12, que todos indicadores referentes aos mecanismos de transferência de conhecimento da subsidiária para a matriz e das barreiras na transferência de conhecimento tanto da matriz para a subsidiária, quanto no sentido contrário, foram validados.

Em relação aos indicadores da iniciativa interna, a Tabela 12 indica que somente três destes foram retirados: RIPOS 5 - aquisição de companhias nacionais conduzida pela subsidiária; RIPOS 3 - Resultados bem sucedidos dos investimentos no país e RIPOS 6 - Atividades inovadoras de negócio internacional criadas no país. Assim, a iniciativa interna foi mensurada por seis indicadores que apresentaram cargas fatoriais superiores a 0,7 (Tabela 14).

No entanto, em relação à iniciativa externa, ou seja, como as relações dos atores do contexto local têm influenciado à subsidiária, cinco indicadores foram retirados: REL 4 - clientes de mercados específicos; REL 3 - clientes corporativos preferenciais no país; REL 1 - a matriz localizada no Brasil; REL 12 - instituições governamentais e REL 8 - competidores específicos. Ainda assim, a iniciativa externa foi mensurada por sete indicadores que apresentaram cargas fatoriais superiores a 0,67 (Tabela 14).

Observa-se que a cultura foi o construto com maiores impactos visto as retiradas dos indicadores com cargas baixas (9 do total inicial de 15), conforme Tabela 12. Neste caso, mesmo utilizando no questionário afirmativas validadas por estudos anteriores de Hofstede (2005), não houve resultados positivos. No entanto, os seis indicadores que permaneceram (HOF 4 - distância do poder, HOF 5 - individualismo, HOF 8 e 9 - masculinidade e HOF 11 e 12 - controle de incertezas) são suficientes para explicar o construto cultura. 


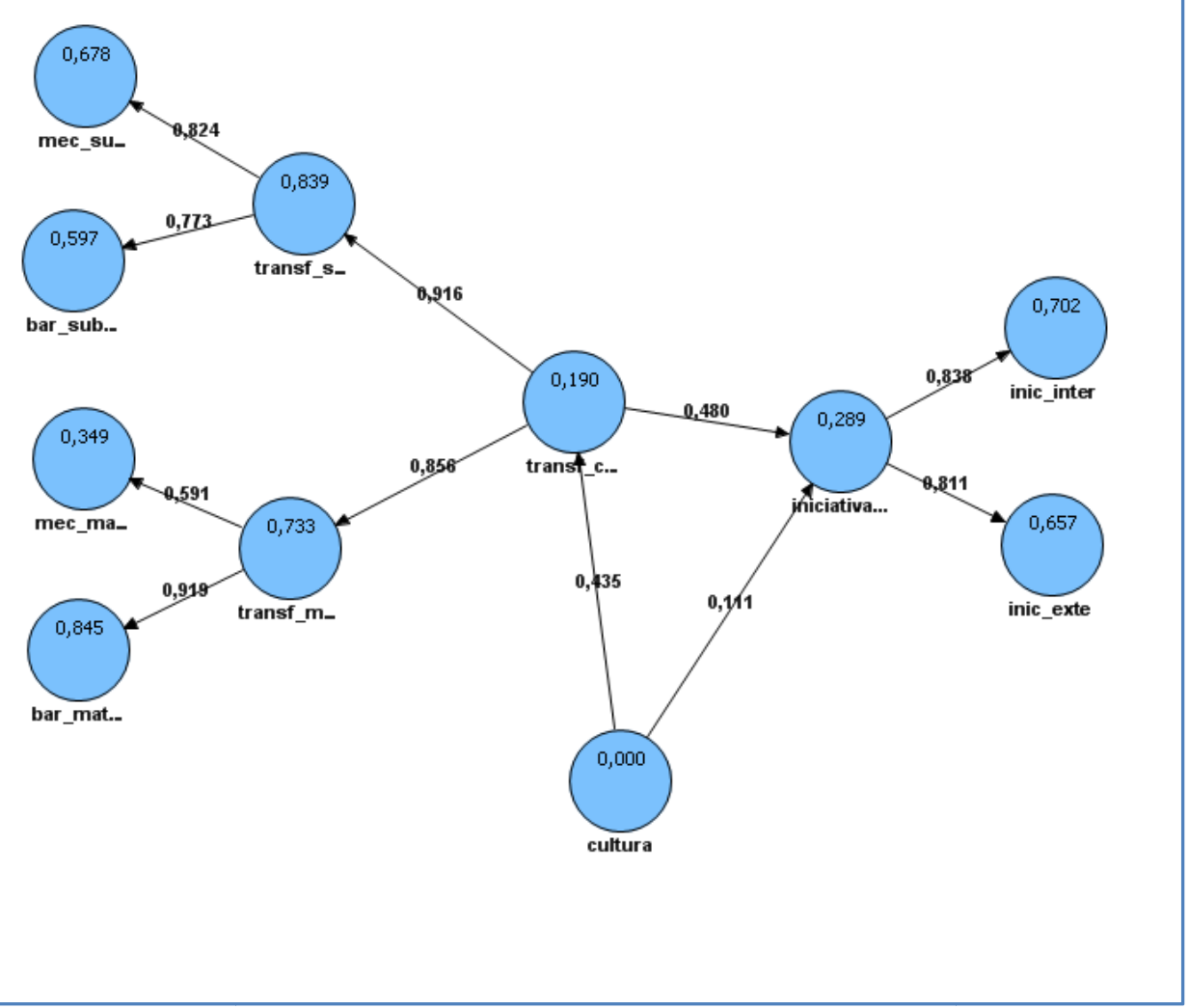

Ilustração 12- Modelo de mensuração final ( $9^{\mathrm{a}}$ estimação)

Nota: Os indicadores não foram incluídos nesta figura apenas por questão estética, mas as cargas fatoriais são apresentadas na Tabela 14 e no Apêndice 4

A avaliação do modelo de mensuração é feita para demonstrar um nível satisfatório de validade e confiabilidade. Os parâmetros utilizados para cumprir com esta condição são: validade de conteúdo, validade convergente, confiabilidade composta e validade discriminante, conforme explicitado na metodologia.

Em relação a validade de conteúdo, para a construção do instrumento de coleta de dados, conforme explicitado nos procedimentos metodológicos, a partir de teorias de referência para dois construtos (transferência de conhecimento e iniciativa), elencou-se variáveis pertinentes (indicadores reflexivos) e elaborou-se afirmativas correspondentes. Em relação ao construto cultura, utilizou-se questões previamente validadas pelo teórico Hofstede (2005).

A validade de conteúdo foi garantida na elaboração do instrumento de coleta de dados, quando professores especialistas na área analisaram as afirmativas e os seus respectivos construtos, além da realização de um pré-teste com uma multinacional e respectiva subsidiária. 
Após a exclusão das variáveis com cargas fatoriais menores que 0,7 , ou seja, considerando-se o modelo final ( $9^{\mathrm{a}}$ estimação), observa-se que os valores da average variance extracted - AVE (variância média extraída) em todos os construtos do modelo são iguais ou superiores a 0,5, sendo esta a condição mínima exigida para que se tenha validade convergente (HAIR et al, 2006). Logo, a validade convergente do modelo é satisfeita, conforme apresentado na Tabela 13.

Tabela 13 - Valores da AVE e confiabilidade composta

\begin{tabular}{c|c|r|r|r}
\hline & Ordem & AVE & Confiabilidade Composta & Alfa de Cronbachs \\
\hline bar_mat_sub & 1VL & 0,743 & 0,958 & 0,949 \\
\hline bar_sub_matr & 1VL & 0,701 & 0,949 & 0,938 \\
\hline Cultura & 1VL & 0,491 & 0,852 & 0,796 \\
\hline inic_exte & 1VL & 0,539 & 0,891 & 0,857 \\
\hline inic_inter & 1VL & 0,633 & 0,912 & 0,883 \\
\hline iniciativa_sub & 2VL & 0,680 & 0,809 & 0,870 \\
\hline mec_mat_sub & 1VL & 0,614 & 0,917 & 0,894 \\
\hline mec_sub_matr & 1VL & 0,677 & 0,954 & 0,946 \\
\hline transf_conhec & 3 VL & 0,786 & 0,880 & 0,937 \\
\hline transf_mat_sub & 2 VL & 0,597 & 0,739 & 0,899 \\
\hline transf_sub_matr & 2VL & 0,638 & 0,779 & 0,924 \\
\hline
\end{tabular}

Cabe salientar que todas as cargas fatoriais foram significantes $(\mathrm{p}<0,001)$. Segundo procedimento recomendado por Henseler, Ringle e Sinkovics (2009), a significância foi estimada por bootstrap com $n=66$ casos e 1.000 reamostragens e opção Individual changes.

Para as variáveis de segunda ordem (iniciativa da subsidiária, transferência de conhecimento da matriz para a subsidiária e transferência de conhecimento da subsidiária para a matriz), bem como de terceira ordem (transferência de conhecimento), os valores da AVE e confiabilidade composta não são resultantes diretos do software SmartPLS, necessitando de cálculos a parte.

A validade convergente também foi avaliada pelas cargas fatoriais. Observa-se na Tabela 14 que a maioria dos itens possui carga fatorial superior a $0,7(\mathrm{p}<0,001)$ e mesmo nos casos em que ocorreram alguns itens com cargas inferiores a 0,7 , não prejudicou a medida de AVE, confirmando a validade convergente.

A confiabilidade foi avaliada pela confiabilidade composta e pelo alfa de Cronbach (Tabela 13) e ambos estão acima do valor mínimo recomendado, de 0,7, segundo (HAIR et al, 2005). 
Analisando-se as cargas cruzadas do modelo de mensuração, observa-se que todas as variáveis possuem cargas maiores nas suas respectivas variáveis latentes (VL) do que em qualquer outra VL, o que indica a existência de validade discriminante para esses construtos, conforme apresentado na Tabela 14. 
Tabela 14 - Indicadores e suas respectivas cargas cruzadas do modelo final

\begin{tabular}{|c|c|c|c|c|c|c|c|}
\hline Indicadores & $\begin{array}{c}\text { bar_mat_s } \\
\text { ub }\end{array}$ & $\begin{array}{c}\text { bar_sub_str } \\
\text { matr }\end{array}$ & cultura & inic_exte & inic_inter & $\begin{array}{c}\text { mec_mat_su } \\
\text { b }\end{array}$ & $\begin{array}{c}\text { mec_sub_mat } \\
\mathbf{r}\end{array}$ \\
\hline bk1 & 0,854 & 0,626 & 0,204 & 0,170 & 0,264 & 0,131 & 0,103 \\
\hline bk2 & 0,657 & 0,473 & 0,288 & 0,182 & 0,241 & 0,167 & 0,295 \\
\hline bk3 & 0,888 & 0,748 & 0,196 & 0,199 & 0,217 & 0,174 & 0,161 \\
\hline bk4 & 0,881 & 0,701 & 0,310 & 0,223 & 0,267 & 0,195 & 0,237 \\
\hline bk5 & 0,882 & 0,591 & 0,288 & 0,220 & 0,252 & 0,224 & 0,152 \\
\hline bk6 & 0,927 & 0,651 & 0,250 & 0,100 & 0,234 & 0,229 & 0,098 \\
\hline bk7 & 0,899 & 0,624 & 0,289 & 0,110 & 0,140 & 0,222 & 0,086 \\
\hline bk8 & 0,879 & 0,661 & 0,280 & 0,205 & 0,277 & 0,207 & 0,082 \\
\hline bks1 & 0,490 & 0,819 & 0,258 & 0,168 & 0,359 & 0,101 & 0,223 \\
\hline bks2 & 0,503 & 0,699 & 0,301 & 0,227 & 0,192 & 0,032 & 0,338 \\
\hline bks3 & 0,666 & 0,927 & 0,346 & 0,211 & 0,308 & 0,106 & 0,286 \\
\hline bks4 & 0,703 & 0,892 & 0,242 & 0,249 & 0,360 & 0,083 & 0,321 \\
\hline bks5 & 0,584 & 0,807 & 0,512 & 0,205 & 0,327 & 0,198 & 0,209 \\
\hline bks6 & 0,709 & 0,876 & 0,264 & 0,162 & 0,231 & 0,095 & 0,115 \\
\hline bks7 & 0,713 & 0,870 & 0,256 & 0,176 & 0,254 & 0,037 & 0,222 \\
\hline bks8 & 0,557 & 0,785 & 0,166 & 0,181 & 0,260 & $-0,125$ & 0,080 \\
\hline hof11 & 0,162 & 0,214 & 0,706 & 0,155 & 0,169 & 0,128 & 0,021 \\
\hline hof12 & 0,056 & 0,131 & 0,719 & 0,200 & 0,257 & 0,120 & 0,177 \\
\hline hof4 & 0,292 & 0,445 & 0,632 & $-0,024$ & 0,226 & $-0,018$ & 0,229 \\
\hline hof5 & 0,362 & 0,359 & 0,720 & 0,183 & 0,182 & 0,350 & 0,236 \\
\hline hof8 & 0,078 & 0,082 & 0,664 & 0,024 & 0,287 & 0,259 & 0,235 \\
\hline hof9 & 0,205 & 0,154 & 0,755 & 0,217 & 0,292 & 0,156 & 0,298 \\
\hline $\mathrm{k} 1$ & 0,300 & 0,143 & 0,309 & 0,241 & 0,321 & 0,803 & 0,366 \\
\hline k2 & 0,225 & 0,120 & 0,121 & 0,089 & $-0,010$ & 0,737 & 0,216 \\
\hline $\mathrm{k} 3$ & 0,171 & 0,050 & 0,243 & 0,241 & 0,209 & 0,854 & 0,303 \\
\hline $\mathrm{k} 4$ & 0,098 & $-0,064$ & 0,143 & 0,199 & 0,229 & 0,830 & 0,198 \\
\hline k5 & 0,092 & $-0,028$ & 0,212 & 0,235 & 0,243 & 0,848 & 0,276 \\
\hline k7 & 0,138 & $-0,001$ & $-0,008$ & 0,054 & 0,176 & 0,705 & 0,259 \\
\hline $\mathrm{k} 8$ & 0,160 & 0,201 & 0,293 & 0,170 & 0,291 & 0,693 & 0,388 \\
\hline ks1 & 0,149 & 0,182 & 0,250 & 0,358 & 0,415 & 0,372 & 0,759 \\
\hline ks10 & 0,167 & 0,204 & 0,269 & 0,386 & 0,367 & 0,283 & 0,837 \\
\hline ks2 & 0,032 & 0,144 & 0,275 & 0,261 & 0,326 & 0,322 & 0,865 \\
\hline ks3 & 0,076 & 0,149 & 0,268 & 0,465 & 0,446 & 0,343 & 0,867 \\
\hline ks4 & 0,088 & 0,176 & 0,301 & 0,419 & 0,496 & 0,357 & 0,886 \\
\hline ks5 & 0,033 & 0,204 & 0,227 & 0,301 & 0,401 & 0,336 & 0,830 \\
\hline ks6 & 0,082 & 0,184 & 0,180 & 0,330 & 0,318 & 0,379 & 0,785 \\
\hline ks7 & 0,435 & 0,468 & 0,281 & 0,334 & 0,370 & 0,140 & 0,681 \\
\hline ks8 & 0,097 & 0,218 & 0,236 & 0,196 & 0,190 & 0,247 & 0,814 \\
\hline ks9 & 0,198 & 0,299 & 0,190 & 0,276 & 0,279 & 0,281 & 0,878 \\
\hline rel10 & 0,089 & 0,183 & $-0,033$ & 0,826 & 0,317 & 0,100 & 0,390 \\
\hline rel11 & 0,081 & 0,137 & 0,208 & 0,681 & 0,151 & 0,129 & 0,242 \\
\hline rel2 & 0,092 & 0,065 & 0,068 & 0,696 & 0,144 & 0,183 & 0,221 \\
\hline rel5 & 0,315 & 0,287 & 0,219 & 0,765 & 0,381 & 0,216 & 0,266 \\
\hline rel6 & 0,258 & 0,210 & 0,229 & 0,785 & 0,255 & 0,211 & 0,326 \\
\hline rel7 & 0,037 & 0,077 & 0,051 & 0,696 & 0,167 & 0,164 & 0,231 \\
\hline rel9 & 0,115 & 0,208 & 0,210 & 0,677 & 0,362 & 0,173 & 0,369 \\
\hline ripos1 & 0,316 & 0,405 & 0,264 & 0,325 & 0,836 & 0,244 & 0,347 \\
\hline ripos2 & 0,194 & 0,210 & 0,219 & 0,181 & 0,774 & 0,204 & 0,273 \\
\hline ripos4 & 0,218 & 0,234 & 0,219 & 0,290 & 0,845 & 0,157 & 0,357 \\
\hline ripos7 & 0,202 & 0,283 & 0,213 & 0,224 & 0,803 & 0,236 & 0,286 \\
\hline ripos8 & 0,189 & 0,264 & 0,380 & 0,310 & 0,781 & 0,219 & 0,324 \\
\hline ripos9 & 0,173 & 0,235 & 0,291 & 0,371 & 0,728 & 0,218 & 0,493 \\
\hline
\end{tabular}


Outra forma de verificar a existência de validade de discriminante é a proposta por Fornell e Larcker (1981). De acordo com os autores, a validade discriminante é satisfeita caso o valor da raiz quadrada da AVE, necessário para tornar as grandezas comparáveis às correlações, seja maior que os valores das correlações com as demais variáveis latentes, representando que os próprios indicadores da variável latente possuem maior poder de explicação do que qualquer outra variável latente do modelo.

Na Tabela 15, verifica-se que as variáveis latentes satisfazem a essa condição, uma vez que os valores da raiz quadrada da AVE para cada construto (postados na diagonal da matriz de correlação na Tabela 15) são maiores que as correlações do mesmo com as demais variáveis latentes.

Tabela 15 - Correlação entre as variáveis latentes (Modelo de mensuração final)

\begin{tabular}{|c|c|c|c|c|c|c|c|}
\hline Variável latente de $1^{\mathrm{a}}$ ordem & 1 & 2 & 3 & 4 & 5 & 6 & 7 \\
\hline $\begin{array}{l}1 \text { - Barreiras de transferência de } \\
\text { conhecimento da matriz para a subsidiária }\end{array}$ & 0,862 & & & & & & \\
\hline $\begin{array}{l}2 \text { - Barreiras de transferência de } \\
\text { conhecimento da subsidiária para a matriz }\end{array}$ & 0,739 & $\mathbf{0 , 8 3 7}$ & & & & & \\
\hline 3 - cultura & 0,304 & 0,352 & 0,701 & & & & \\
\hline 4 - Iniciativa externa & 0,202 & 0,238 & 0,186 & 0,734 & & & \\
\hline 5 - Iniciativa interna & 0,273 & 0,345 & 0,334 & 0,360 & 0,795 & & \\
\hline $\begin{array}{l}6 \text { - Mecanismos de transferência de } \\
\text { conhecimento da matriz para a subsidiária }\end{array}$ & 0,226 & 0,084 & 0,248 & 0,229 & 0,268 & 0,784 & \\
\hline $\begin{array}{l}7 \text { - Mecanismos de transferência de } \\
\text { conhecimento da subsidiária para a matriz }\end{array}$ & 0,170 & 0,276 & 0,302 & 0,405 & 0,439 & 0,370 & 0,823 \\
\hline \multicolumn{3}{|c|}{$\begin{array}{c}\text { Variável latente do modelo } \\
\text { estrutural }\end{array}$} & 1 & \multicolumn{2}{|c|}{2} & \multicolumn{2}{|l|}{3} \\
\hline \multicolumn{3}{|l|}{1 - Cultura } & $\mathbf{0 , 7 0 1}$ & & & & \\
\hline \multicolumn{3}{|c|}{2 - Iniciativa da subsidiária } & 0,320 & \multicolumn{2}{|c|}{0,825} & & \\
\hline \multicolumn{3}{|c|}{3 - Transferência do conhecimento } & 0,435 & \multicolumn{2}{|c|}{0,528} & \multicolumn{2}{|l|}{$\mathbf{0 , 8 8 7}$} \\
\hline
\end{tabular}

Nota: na diagonal estão os valores da raiz quadrada da variância média extraída.

Comparando-se as correlações da iniciativa com a transferência de conhecimento $(0,528)$ e daquela com a cultura $(0,320)$, constata-se que é mais representativa no primeiro caso, sendo ambas positivas. Isto indica que quanto maior a transferência de conhecimento entre a matriz e a subsidiária, maior será a iniciativa desta.

Cabe salientar também que a correlação entre a cultura e a transferência de conhecimento também é positiva, apesar de apresentar baixa magnitude $(0,435)$. Desta maneira, quanto mais 
alto o valor da cultura, maior será a transferência de conhecimento, ou seja, quanto mais próxima a cultura local, da subsidiária, à brasileira, mais efetivo será o compartilhamento de conhecimentos e práticas.

É possível constatar que existe uma alta correlação $(0,739)$ entre as barreiras de transferência de conhecimento da subsidiária para matriz (2) e as barreiras de transferência de conhecimento da matriz para a subsidiária (1). Isto indica que as subsidiárias, quando percebem barreiras no processo de transferência de conhecimento, não fazem distinção se estas são oriundas na matriz ou na própria subsidiária.

Outro ponto interessante a ser destacado é que os mecanismos de transferência de conhecimento da subsidiária para a matriz apresentam maior correlação em relação a iniciativa interna $(0,439)$ e iniciativa externa $(0,405)$ do que os mecanismos de transferência da matriz para a subsidiária. Uma explicação possível para este resultado é o fato de as subsidiárias que promovem a iniciativa, ou seja, identificam oportunidades de negócios, desejam ou necessitam compartilhar com a matriz e, consequentemente, melhorar a credibilidade perante a multinacional.

Em relação à cultura, observa-se que a correlação desta com a iniciativa externa $(0,186)$ é inferior à iniciativa interna $(0,334)$, embora ambas obtenham valores de baixa magnitude. Assim, considerando-se que na iniciativa externa o principal para a subsidiária é fomentar a rede local de contatos e, a partir deste, identificar oportunidades de negócios, a cultura mais similar às características do Brasil (valores mais altos) acaba sendo indiferente.

\subsubsection{2 - Avaliação do modelo estrutural}

A partir dos resultados obtidos no modelo de mensuração final (Ilustração 12), realizou-se a avaliação do modelo estrutural estimado por meio da técnica bootstrapping com 66 casos e 1000 repetições, obtendo-se os valores t-student. Para 66 graus de liberdade, para um intervalo de confiança de $95 \%$, tem-se o valor crítico t de student de 1,968. A Ilustração 13 apresenta o modelo estrutural com os coeficientes estruturais, após o teste bootstrapping, utilizando -se o software SmartPLS. 


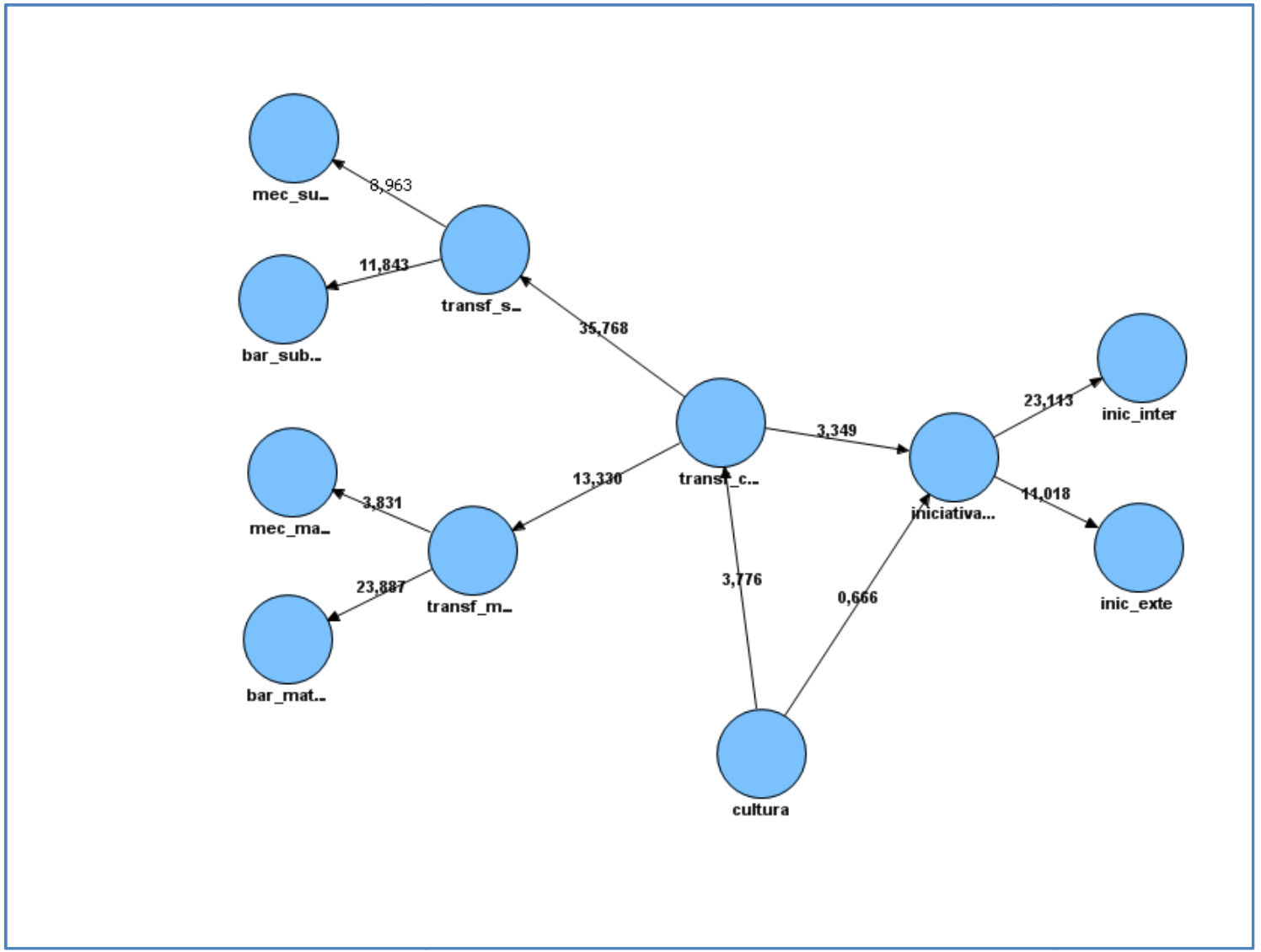

Ilustração 13- Bootstrapping do modelo estrutural final (valores t)

Nota: Coeficientes com valores t superiores a 1,96 são significantes a 5\% (bicaudal).

A Ilustração 14 apresenta o modelo final ajustado de mensuração após os processamentos (nove estimações), considerando os três construtos principais em estudo.

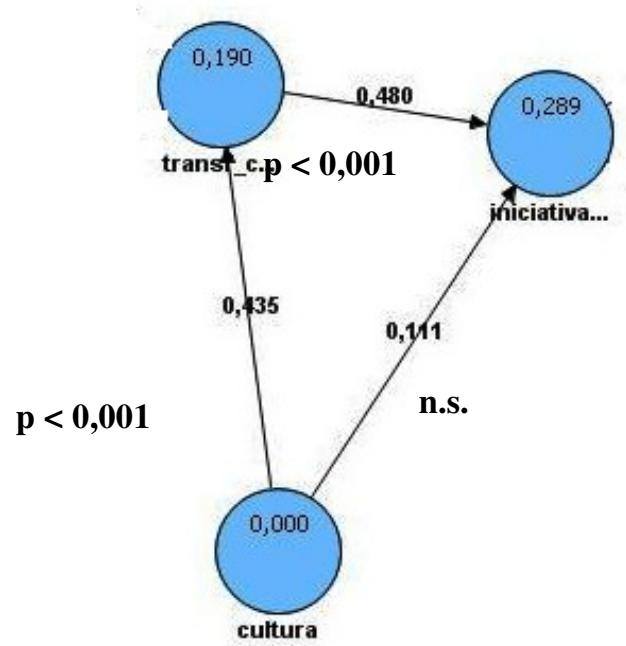

Ilustração 14 - Modelo de mensuração - principais construtos 
Por meio da Ilustração 14, observa-se que dos construtos com efeitos direitos sobre a iniciativa da subsidiária, a transferência de conhecimento é o que exerce maior influência $(0,480, \mathrm{p}<0,001)$, enquanto o efeito direto da cultura na iniciativa da subsidiária é nulo $(0,111, \mathrm{p}>0,3)$.

A transferência do conhecimento, por sua vez, recebe efeito direito da cultura de 0,435 ( $\mathrm{p}<$ 0,001), com $19 \%$ de sua variabilidade, sendo explicada pelo modelo. Entretanto, cabe salientar que existe um efeito indireto da cultura na iniciativa $(0,21=0,435 * 0,480)$, isto é, a cultura influencia a transferência de conhecimento e este influencia a iniciativa.

Considerando o modelo (Ilustração 14), o Goodness-of-fit foi igual a 0,59 e este valor pode ser interpretado como se fosse um índice geral do modelo, representando a média geométrica entre o $\mathrm{R}^{2}$ médio (adequação do modelo estrutural) e a AVE média (adequação do modelo de mensuração). Tenenhuaus et al (2005 apud Bido et al, 2008) não propõem um ponto de corte desta medida; mas Wetzels et al (2009) sugerem que 0,36 seja considerado como GoF grande, logo, o valor obtido neste estudo está bem acima deste critério, visto que se apresenta como um resultado positivo.

Analisando-se o modelo como um todo, é claro explicar os $28,9 \%$ da variância da iniciativa da subsidiária. Considerando a área de ciências sociais e do comportamento, Cohen (1977) sugere a seguinte classificação: $\mathbf{R}^{2}=0,02$ (pequeno); $\mathrm{R}^{2}=0,13$ (médio) e $\mathrm{R}^{2}=0,26$ (grande). Logo, pode-se considerar que o modelo explica uma boa parcela da variabilidade da iniciativa $\left(\mathrm{R}^{2}=0,289\right)$.

Em relação ao efeito do tamanho da amostra analisada (66 unidades), conforme apresentado no capítulo de metodologia, para que houvesse significância para o estudo, o $\mathrm{R}^{2}$ deveria ser superior a $13,3 \%$. Logo, como o resultado foi de 28,9\%, entende-se que o número de subsidiárias, embora reduzido, foi suficiente para validar o modelo de pesquisa.

\subsection{2 - Análise dos resultados da modelagem de equações estruturais}

Conforme mencionado anteriormente, a aplicação da técnica de modelagem de equações estruturais teve como objetivo verificar a existência da influência da cultura e da transferência de conhecimento na iniciativa da subsidiária. Assim, os resultados estatísticos obtidos na 
seção anterior são discutidos à luz do referencial e modelo teórico; e às hipóteses, aplicado à realidade das subsidiárias de multinacionais brasileiras.

Para o contexto em estudo, das multinacionais brasileiras, a transferência de conhecimento da matriz para a subsidiária é explicada pela utilização dos seguintes mecanismos: realização de reuniões com os executivos principais da matriz, recepção de executivos brasileiros, realização de treinamentos e viagens para a matriz, manuais de orientação de trabalho, benchmarking interno e banco de melhores práticas. Salienta-se que enquanto a

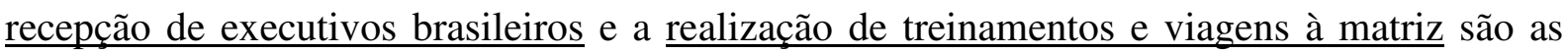
práticas mais relevantes para disseminarem conhecimentos com as unidades provendo processos de iniciativa; a contratação de consultores especializados e a recepção de uma equipe de projetos da matriz não são.

No entanto, o processo no sentido oposto, ou seja, a transferência de conhecimento da subsidiária para a matriz ocorre por meio dos diversos mecanismos, conforme explorado nas seções anteriores.

Em relação às barreiras na transferência de conhecimento, em ambos os sentidos, todas as variáveis contribuem para a construção dos construtos. Se por um lado, no caso da transferência de conhecimento da matriz para a subsidiária, as barreiras que mais contribuíram para este construto foram: falta de incentivos para o compartilhamento do conhecimento e as distorções na transmissão da atividade devido à estrutura hierárquica; por outro, no sentido oposto, da subsidiária para a matriz, a necessidade de demanda de recursos para o compartilhamento das práticas e a sensação de que a atividade não era importante para a corporação foram os indicadores que mais contribuíram.

Sobre a iniciativa interna, observa-se que novos produtos, desenvolvidos na unidade e vendidos internacionalmente, bem como a transferência do processo de produção para o país da subsidiária e a expansão da linha de produtos foram as variáveis que mais contribuíram para o construto. Na iniciativa externa, os relacionamentos com unidades de pesquisa e desenvolvimento (P\&D) de outras empresas e com fornecedores tanto de mercado específico quando corporativos, foram as variáveis que mais contribuíram para o construto.

O construto cultura é representado por poucas variáveis que correspondem de maneira geral, às dimensões do Hofstede: distância do poder, individualismo, masculinidade e controle das 
incertezas; indicando que quanto mais alto o valor resultante, mais similar a cultura da subsidiária se apresenta em relação à cultura brasileira.

No contexto deste estudo, das multinacionais brasileiras, a variabilidade da iniciativa da subsidiária é explicada 28,9\% pelo modelo proposto, sendo um resultado satisfatório para estudos em ciências sociais; visto que se utiliza somente de dimensões predominantemente comportamentais (transferência de conhecimento e cultura), enquanto que o de Birkinshaw (1999) apresenta também dimensões estruturais.

Logo, os 71,1\% (complementares aos 28,9\%) da variabilidade da iniciativa podem ser explicados com outras variáveis, ou seja, outras dimensões do contexto corporativo ou da subsidiária brasileira que afetam a iniciativa da subsidiária, principalmente aquelas referentes ao contexto estrutural da multinacional, que não fazem parte da abordagem desta pesquisa.

Em relação ao contexto corporativo, além da comunicação, dimensão comportamental representada neste estudo pela transferência de conhecimento entre a matriz e a subsidiária, Birkinshaw (1999) indicou duas dimensões estruturais: centralização da decisão e credibilidade da subsidiária perante a matriz.

Em relação à centralização da decisão, nas discussões sobre o resultado da pesquisa, nas seções anteriores, observou-se que uma das barreiras à transferência de conhecimento entre as unidades é a estrutura hierárquica, decorrente de um modelo de alto controle de gestão por parte da matriz brasileira.

Essa forma de atuação das multinacionais é decorrente da influência de características culturais brasileiras, que de alguma maneira, interferem positiva ou negativamente na gestão das subsidiárias. A análise sobre os dados de cultura permitiu identificar uma interferência do modelo de gestão brasileiro nas subsidiárias, mesmo naquelas que possuem aspectos culturais diferentes do Brasil.

Assim, mesmo não sendo foco deste estudo, a centralização das decisões é um aspecto relevante e que mesmo indiretamente, pode afetar negativamente a iniciativa das subsidiárias, seja por meio de barreiras à transferência de conhecimentos quanto pela própria característica do estilo gerencial brasileiro.

Em relação à credibilidade da subsidiária pela matriz, apesar de não ser a intenção da investigação deste estudo, há evidências da sua ocorrência e impacto nas relações internas das 
multinacionais brasileiras. A falta de credibilidade pode ser decorrente de outra barreira à transferência de conhecimento entre as unidades, a síndrome do "não inventado aqui', ou seja, as subsidiárias brasileiras percebem muitas vezes que a matriz brasileira não reconhece e nem valoriza as contribuições oriundas daquelas. Assim, sem o reconhecimento da subsidiária por parte da matriz, não há como estruturar um relacionamento de confiança e credibilidade.

No âmbito da subsidiária, além da dimensão cultural, Birkinshaw (1999) elucidou a importância da liderança e a capacidade distintiva da unidade para a iniciativa do negócio, questões não abordadas no modelo deste estudo.

Assim, esses $71,1 \%$ da variabilidade da iniciativa da subsidiária podem ser explicados pelo grau de centralização das decisões na matriz ou pela falta de credibilidade, estilo de liderança e baixa capacidade distintiva da subsidiária; dimensões propostas no modelo de Birkinshaw (1999). Também, outros fatores ambientais e organizacionais que poderiam promover a iniciativa das subsidiárias devem ser considerados.

Em relação aos fatores ambientais locais, destacam-se questões administrativas (política e educacional) e econômicas, bem como o tamanho do país sede da subsidiária; que Ghemawat (2008) denominou de distâncias geográfica, administrativa e econômica, as quais podem influenciar a atuação e o nível de iniciativa da unidade estrangeira.

Em relação à distancia administrativa, o governo local pode estabelecer barreiras alfandegárias para competição estrangeira: tarifas, cotas, restrições para investimentos diretos e preferência por competidores domésticos com favoritismo na regulamentação (GHEMAWAT, 2008). Desta maneira, pode existir a intenção da subsidiária brasileira à iniciativa externa, mas estas são inviabilizadas pela regulamentação local. Outro aspecto a ser também considerado é o tamanho do país e o mercado consumidor.

O nível de desenvolvimento econômico do país, representando pelo custo e qualidade dos recursos naturais, financeiros, humanos, infraestrutura e informações (GHEMAWAT, 2008), pode influenciar positiva ou negativamente à iniciativa da subsidiária, principalmente à externa. Por exemplo, um país com alto nível de desenvolvimento econômico, tende a possuir organizações que privilegiam novas tecnologias e investimentos nos processos, com contínuo relacionamento com as universidades. Nestes contextos, provavelmente a subsidiária de multinacional brasileira terá maiores oportunidades de negócios e de aprendizado a partir dos contatos locais com clientes e fornecedores. 
Sobre as hipóteses da pesquisa, por meio da modelagem de equações estruturais, foi possível confirmar duas delas, conforme explicitado no Quadro 26.

Quadro 26- Análise das hipóteses do modelo

\begin{tabular}{|l|c|}
\hline \multicolumn{1}{|c|}{ Hipóteses do modelo } & Situação \\
\hline $\begin{array}{l}\text { H1 - A iniciativa da subsidiária é diretamente influenciada pela transferência de } \\
\text { conhecimento }\end{array}$ & Confirmada \\
\hline H2 - A iniciativa da subsidiária é diretamente influenciada pela cultura & Não confirmada \\
\hline H3 - A transferência de conhecimento é diretamente influenciada pela cultura & Confirmada \\
\hline
\end{tabular}

A hipótese 1 ( $\left.\begin{array}{ll}\text { H } & 1\end{array}\right)$ - a iniciativa da subsidiária é diretamente influenciada pela transferência de conhecimento - foi confirmada com a amostra estudada.

Segundo Birkinshaw (1999), os fluxos de recursos, principalmente o conhecimento, representam o elemento central do desenvolvimento da subsidiária, permitindo iniciativas específicas e também o seu processo de crescimento contínuo.

Nas multinacionais brasileiras, a transferência de conhecimento influencia em $25,3 \%$ a iniciativa da subsidiária, indicando que aquela que possui conhecimento é capaz de tomar melhores decisões e, com isso contribuir mais para o seu desenvolvimento eficiente, buscando oportunidades de negócios tanto no ambiente corporativo quanto no local (NOHRIA; GHOSHAL, 1994).

Cabe salientar que a transferência de conhecimento da subsidiária para a matriz apresenta maior relação com a iniciativa da unidade. Isto se justifica diante da visão do modelo dinâmico, ou seja, ao mesmo tempo em que novos conhecimentos são insumos para a iniciativa, esta pode ser insight para novos conhecimentos que são disseminados para as demais unidades da multinacional. Assim, a partir do momento em que a subsidiária identifica novas oportunidades de negócios ou melhorias de processos, seus gestores se fortalecem, aumentando a credibilidade da unidade diante da matriz.

Quanto mais dinâmico esse processo de disseminação do conhecimento (GUPTA; GOVINDARAJAN, 1991) entre todas as unidades estrangeiras, provavelmente possibilidades maiores de visualização de novas oportunidades, visto que a subsidiária brasileira passará a compreender e dominar cada vez mais o negócio da multinacional. Ao atingir este estágio, estará desenvolvendo a aprendizagem organizacional, decorrente da fluidez rápida e eficaz do conhecimento (GARVIN, 2000) no contexto da corporação. 
Visto que neste estudo, o contexto comportamental é caracterizado pelos aspectos culturais da subsidiária, a hipótese 2 (H 2) - a iniciativa da subsidiária é diretamente influenciada pela cultura - não foi confirmada, assim como não o foi nas pesquisas de Birkinshaw (1999).

É interessante relembrar que nas pesquisas de Birkinshaw (1999), que buscaram verificar a aplicação do modelo dos contextos corporativo e da subsidiária e suas relações com a iniciativa, não houve evidências de que o contexto comportamental, ou seja, o local de trabalho profundamente enraizado na ética empresarial, valorizado pelo empreendedorismo, colaboração e aprendizagem, fosse promotor da iniciativa.

Assim, por mais que pareça evidente que uma cultura organizacional centrada em processos de aprendizagem e que fomente ações empreendedoras possa influenciar positivamente a identificação de oportunidades de negócios, tanto os resultados das pesquisas anteriores desse autor, como os do presente estudo não comprovam tal afirmação.

A não confirmação da hipótese pode estar relacionada com a abstração do construto cultura e a subjetividade do respondente do instrumento de coleta de dados, pelo fato de apenas um indivíduo de cada subsidiária ter participado da pesquisa; talvez com uma representatividade maior, os resultados pudessem ser diferentes, mais favoráveis.

Outro aspecto que deve ser considerado é a particularidade da amostra estudada, compreendidas por subsidiárias de multinacionais brasileiras. Mesmo que os indivíduos dos países das unidades valorizem ações empreendedoras nas organizações; por se tratarem de subsidiárias de empresas brasileiras, os traços culturais e o estilo de gestão brasileiro, como o baixo caráter empreendedor, se tornam preponderantes.

Apesar de a cultura não apresentar efeito direto na iniciativa das subsidiárias brasileiras, é indispensável para a transferência de conhecimento eficaz e esta, por sua vez, influencia positivamente a iniciativa.

Desta maneira, observa-se que a cultura é relevante no processo de identificação de oportunidades e maximização dos recursos, como aspecto complementar ao contexto institucional da unidade, conforme apresentado por Hayton et al (2002).

\section{A hipótese 3 (H 3) - a transferência de conhecimento é diretamente influenciada pela cultura - também foi confirmada.}


Logo, pode-se afirmar que a cultura influencia diretamente a transferência de conhecimento nas multinacionais brasileiras em todos os sentidos, e esta constatação confirma as evidências de Bhagat et al. (2002), de que a transferência de conhecimento no âmbito internacional é mais efetiva quando o conhecimento a ser transferido é simples, explicito e independente e, envolve o contexto cultural similar. Takeuchi e Nonaka (2008), ao explorarem a gestão do conhecimento, explicitaram que a compreensão do contexto, principalmente, do cultural é fundamental para um eficiente processo de transferência.

A compreensão da cultura é fundamental para a adaptação ao contexto local, desde o momento em que a multinacional brasileira escolhe o país onde irá atuar e, conseqüentemente, define as estratégias e os ajustes necessários ao ambiente da nova subsidiária.

Uma dessas adequações ao contexto local diz respeito à gestão do conhecimento, que permeia desde a questão do idioma até a escolha por estratégias de compartilhamento de práticas entre as unidades, ou seja, a matriz brasileira precisa identificar quais os melhores mecanismos a serem utilizados e que poderão otimizar tal processo.

\section{4 - Configuração de grupos homogêneos de subsidiárias a partir da cultura, transferência de conhecimento e iniciativa}

Visando identificar se existem subsidiárias brasileiras semelhantes em relação à iniciativa, cultura e transferência de conhecimento, utilizou-se a técnica de conglomerados, a partir dos dados consolidados e resultantes da técnica de Modelagem de Equações Estruturais, explorados na seção anterior.

Desta maneira, esta seção está estruturada em duas partes: a primeira, a apresentação da técnica estatística de conglomerados e as análises para a formação dos grupos de subsidiárias e, a segunda os resultados são discutidos à luz do referencial e modelo teórico, aplicado à realidade das subsidiárias de multinacionais brasileiras, que proporcionaram a definição de uma tipologia para as mesmas em relação à iniciativa. 


\subsection{1 - Formação e caracterização dos conglomerados}

Após a utilização da técnica de equações estruturais, para cada uma das 66 subsidiárias de multinacional brasileira da amostra, as variáveis utilizadas resultaram em um valor (escore), na escala razão. Isto possibilitou a utilização da análise de conglomerados visando atingir o objetivo específico de identificar se a cultura, a transferência de conhecimento e a iniciativa permitem a configuração de grupos homogêneos de subsidiárias.

Para a configuração dos conglomerados, utilizou-se os escores de cinco construtos (em destaque na Ilustração 15, para cada uma das subsidiárias: transferência de conhecimento da matriz para a subsidiária, transferência de conhecimento da subsidiária para a matriz, cultura, iniciativa interna e iniciativa externa.

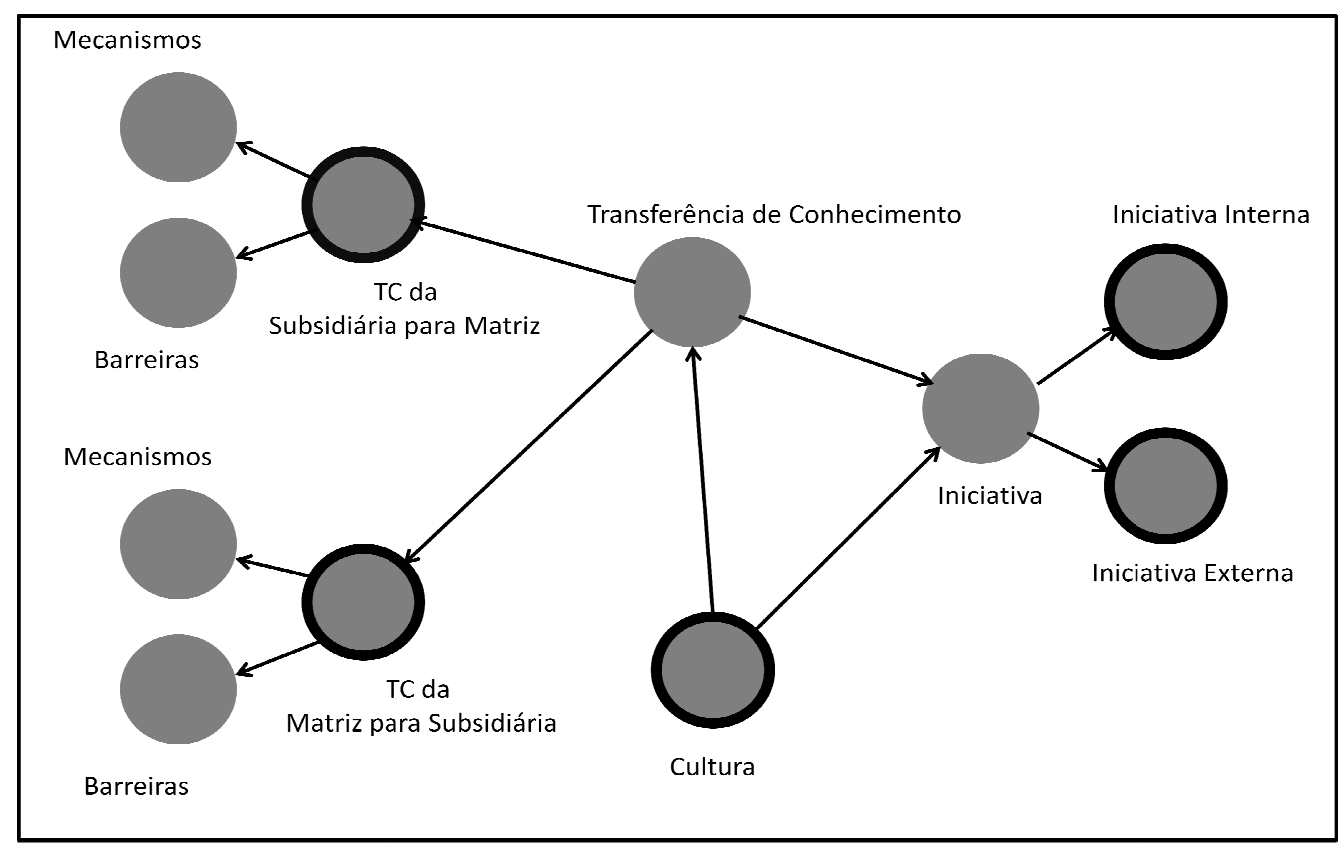

Ilustração 15 - Modelo da pesquisa

Conforme explorado no modelo de pesquisa, os construtos transferência de conhecimento da subsidiária para matriz (transf_sub_matr) e transferência de conhecimento da matriz para subsidiária (transf_mat_sub) são resultantes dos mecanismos de transferência utilizados e das barreiras existentes em cada um dos sentidos.

Considerando os resultados obtidos para os mecanismos, observa-se que quanto maior o valor, maior a utilização dos mesmos, enquanto nas barreiras, quanto menor o valor, menos barreiras existentes no processo. Desta maneira, entende-se que quanto maior o valor dos 
construtos de transferência, maior é o processo de transferência existente em cada um dos sentidos: matriz para subsidiária ou no contrário.

Em relação à iniciativa, capacidade da subsidiária em vislumbrar oportunidades tanto no âmbito interno da multinacional quanto no âmbito externo, para o propósito deste objetivo específico, utilizou-se os dois construtos: iniciativa externa (inic_ext) e iniciativa interna (inic_int).

Nesses casos, quanto maior o valor no construto iniciativa interna indica que a subsidiária identifica oportunidades de negócios para a multinacional como um todo, enquanto que, um valor alto para a iniciativa externa representa que a unidade busca oportunidades de negócios no seu contexto local a partir do relacionamento com os seus clientes, fornecedores e outras entidades.

A cultura, conforme explorado anteriormente, apesar de ser um construto de primeira ordem, principalmente devido o número reduzido de variáveis, é resultante de variáveis que representam as quatro principais dimensões propostas por Hofstede (2005): distância do poder, coletivismo, controle da incerteza e masculinidade.

Na elaboração das questões relativas à cultura no instrumento de coleta de dados, buscou-se estruturar, de forma a analisar o quanto os resultados são similares as características culturais brasileiras, levando-se em consideração o estudo de Hofstede (2005). Assim, quanto mais alto o valor do construto cultura da subsidiária, maior a sua proximidade cultural com o Brasil, cujas características principais são: alto índice de distância do poder e controle de incertezas, coletivista e com tendência a masculinidade.

Em relação ao valor numérico, para cada uma das subsidiárias da amostra, esses construtos apresentam um valor compreendido entre 0 e 5, visto ser uma resultante da escala likert.

Para isso, utilizou-se a técnica estatística de conglomerados hierárquicos, sendo a distância quadrática euclidiana a medida de distância utilizada e, entre grupos (between-groups), o método de aglomeração que prioriza a menor média das distâncias entre todos os pares.

Dentre os resultados encontrados (Apêndice 5), o estágio 63 foi o escolhido, que representa três conglomerados. Processou-se o k-médias (k-means) para três conglomerados, com 100 interações, que permitiu um refinamento dos mesmos e uma análise mais detalhada dos resultados. 
A análise da técnica de conglomerados é reforçada utilizando-se a ANOVA. Observando-se a distribuição F (Tabela 16), como a iniciativa interna apresentou o maior valor $(41,336)$, foi a variável que mais contribuiu para a formação dos conglomerados; enquanto a iniciativa externa foi a de menor contribuição. Outro aspecto verificado foi nível de significância das variáveis. Como todas as variáveis apresentaram nível de significância menor do que 0,05, não houve necessidade de reprocessar os dados.

Tabela 16- Análise da variância dos conglomerados em relação à iniciativa da subsidiária

\begin{tabular}{l|r|r|r|r|r|r}
\hline & \multicolumn{2}{|c|}{ Cluster } & \multicolumn{2}{c|}{ Error } & \multicolumn{1}{c}{ F } & Sig. \\
\cline { 2 - 6 } & Mean Square & df & Mean Square & df & , \\
\hline cultura & 11,226 & 2 &, 461 & 63 & 24,326 &, 000 \\
\hline inic_exte & 12,787 & 2 &, 811 & 63 & 15,771 &, 000 \\
\hline inic_inter & 37,691 & 2 &, 912 & 63 & 41,336 &, 000 \\
\hline transf_mat_sub & 8,770 & 2 &, 495 & 63 & 17,708 &, 000 \\
\hline transf_sub_matr & 14,223 & 2 &, 501 & 63 & 28,379 &, 000 \\
\hline
\end{tabular}

Desta maneira, a Tabela 17 apresenta a distribuição das 66 subsidiárias da amostra em relação aos conglomerados. Observa-se que o conglomerado 1 é o que possui maior representatividade, com 29 unidades, seguido pelo conglomerado 2, formado por 27 unidades e o conglomerado 3, com menor participação, apresentando 10 unidades.

Tabela 17 - Distribuição das subsidiárias nos conglomerados

\begin{tabular}{l|l|r}
\hline \multirow{2}{*}{ Cluster } & 1 & 29,000 \\
\cline { 2 - 3 } & 2 & 27,000 \\
\cline { 2 - 3 } & 3 & 10,000 \\
\hline Valid & 66,000 \\
\hline Missing &, 000 \\
\hline
\end{tabular}

Os valores finais para cada construto nos três conglomerados são apresentados na Tabela 18.

Tabela 18 - Valores finais das variáveis nos três conglomerados

\begin{tabular}{l|r|r|r}
\hline \multirow{2}{*}{ cultura } & \multicolumn{3}{|c}{ Cluster } \\
\cline { 2 - 4 } & \multicolumn{1}{|c}{1} & \multicolumn{1}{c}{2} & \multicolumn{1}{c}{3} \\
\hline inic_exte & 3,5347 & 2,4218 & 2,2201 \\
\hline inic_inter & 2,3116 & 1,2741 & 2,9251 \\
\hline transf_mat_sub & 3,1262 &, 8418 & 2,5590 \\
\hline transf_sub_matr & 3,0960 & 1,9760 & 2,5698 \\
\hline
\end{tabular}


Os valores expostos na Tabela 18 permitem uma caracterização inicial dos três conglomerados. Considerando que estes valores finais poderiam oscilar entre 0 e 5 , observase que os valores são predominantemente baixos ou médios. No entanto, visando facilitar a análise, procurou-se classificar tais números em categorias tais como: alto (superior a 3,5), médio alto (entre 2,7 e 3,4), médio (entre 2,1 e 2,6) e baixo (inferior a 2,0), conforme Quadro 27.

Quadro 27 - Caracterização inicial dos conglomerados

\begin{tabular}{|c|c|c|c|}
\hline \multirow{2}{*}{ Construtos } & \multicolumn{3}{|c|}{ Conglomerados } \\
\cline { 2 - 4 } & C 1 & C 2 & C 3 \\
\hline Iniciativa interna & Médio alto & Baixo & Médio \\
\hline Iniciativa externa & Médio & Baixo & Médio alto \\
\hline Cultura & Alto & Médio & Médio \\
\hline Transf. Conh. Mat. Sub. (TC_MS) & Médio alto & Baixo & Médio \\
\hline Transf. Conh. Sub. Mat. (TC_SM) & Médio & Baixo & Médio \\
\hline
\end{tabular}

Logo, observa-se que o conglomerado 1 (C 1) apresenta valores altos para a cultura, médio para a iniciativa externa e transferência de conhecimento da subsidiária para a matriz e, valores médio alto para iniciativa interna e transferência de conhecimento da matriz para a subsidiária.

Todavia, o conglomerado 2 (C 2) apresenta valor médio para a cultura e valores baixos para as demais variáveis. Desta maneira, visto que para as duas iniciativas os valores foram baixos, entende-se que as subsidiárias deste grupo visualizam muito poucas oportunidades de negócios no seu mercado local como na corporação como um todo.

Diferentemente, no conglomerado 3, o valor da iniciativa externa foi considerado médio alto, enquanto os demais, médio. Este grupo representa subsidiária que buscam e identificam muito mais oportunidades por meio dos seus relacionamentos no contexto local, ou seja, a partir do contato com os seus clientes, fornecedores e outras entidades.

\subsection{2 - Análise sobre os conglomerados}

A utilização da técnica estatística de conglomerados, conforme mencionado anteriormente, permitiu reduzir a amostra de 66 subsidiárias em três grupos, formados a partir dos valores de cultura, transferência de conhecimento (matriz para subsidiária e vice-versa) e iniciativas (interna e externa) provenientes da modelagem de equações estruturais. 
Esses resultados são discutidos à luz do modelo proposto e à sustentação teórica desta pesquisa. Salienta-se que, como é dinâmico, o modelo relaciona a transferência de conhecimento e a cultura com a iniciativa da subsidiária, sendo esta última sempre o ponto inicial para discussão dos resultados apresentados. Ressalta-se que a iniciativa da subsidiária pode ocorrer de duas maneiras: interna, no contexto da corporação como um todo ou externa, quando a unidade busca oportunidades de negócios somente no seu mercado local.

Cabe destacar que Birkinshaw (1995) desenvolveu uma tipologia para a iniciativa das subsidiárias, na qual relacionou o contexto de oportunidade de mercado utilizado pela unidade e o envolvimento da matriz no processo, em quatro categorias: iniciativa de reconfiguração, iniciativa no mercado local, iniciativa de proposta competitiva e a iniciativa da extensão do mandato.

Assim, fundamentado na proposta dessa tipologia, buscou-se uma interpretação dos conglomerados das subsidiárias brasileiras, denominando-os conforme as características da iniciativa. Para os conglomerados 1 e 3 foram utilizadas categorias predeterminadas na tipologia do Birkinshaw (1995): iniciativa de reconfiguração e iniciativa no mercado local, respectivamente. Entretanto, não foi possível classificar o conglomerado 2, diante da tipologia, visto suas características e, por isso, foi criada a denominação de iniciativa incipiente.

\begin{tabular}{|} 
Quadro 28 - Nomeação e caracterização dos conglomerados \\
\begin{tabular}{|c|c|c|c|}
\hline Característica & Conglomerado 1 & Conglomerado 2 & Conglomerado 3 \\
\hline Nomenclatura & $\begin{array}{c}\text { Iniciativa de } \\
\text { Reconfiguração }\end{array}$ & Iniciativa Incipiente & $\begin{array}{c}\text { Iniciativa no } \\
\text { Mercado Local }\end{array}$ \\
\hline Iniciativa interna & Médio alto & Baixo & Médio \\
\hline Iniciativa externa & Médio & Baixo & Médio alto \\
\hline Cultura & Alto & Médio & Médio \\
\hline $\begin{array}{c}\text { Transferência de } \\
\text { Conhecimento da Matriz para } \\
\text { Subsidiária (TC_MS) }\end{array}$ & Médio alto & Baixo & Médio \\
\hline $\begin{array}{c}\text { Transferência de } \\
\text { Conhecimento da Subsidiária } \\
\text { para Matriz ( TC_SM) }\end{array}$ & Médio & Baixo & \\
\hline Continente & $\begin{array}{l}\text { - América (do Norte) } \\
\text { - Europa } \\
\text { - Ásia }\end{array}$ & $\begin{array}{l}\text { - América (Latina) } \\
\text { - África }\end{array}$ & - América (Latina) \\
\hline - Montadoras de & - Recursos naturais & - Insumos básicos \\
\hline sistemas; \\
- Serviços e TI
\end{tabular} & & \\
\hline
\end{tabular}

O Quadro 28 apresenta a caracterização dos três conglomerados sobre as iniciativas interna e externa, cultura, transferência de conhecimento entre matriz e subsidiária. Também, buscou- 
se assinalar a predominância em cada grupo dos continentes que sediam as unidades, bem como o setor de cada uma.

As subsidiárias brasileiras do conglomerado 1, nomeadas como Iniciativa de Reconfiguração, conforme tipologia proposta por Birkinshaw (1995), apresentam predominantemente a iniciativa interna, apesar de identificarem oportunidades locais de aplicação e ampliação dos seus recursos.

É interessante destacar que neste grupo, formado por unidades alocadas principalmente na América do Norte, Europa e Ásia, continentes diferentes em termos culturais do Brasil, os valores da cultura e da transferência de conhecimento da matriz para a subsidiária são significativos, indicando que existe uma similaridade da cultura da unidade em relação à brasileira, ou seja, que alguns aspectos da cultura do Brasil podem estar presentes na dinâmica das unidades. Algo natural, visto que as subsidiárias da amostra são unidades de multinacionais brasileiras.

Desta maneira, como já discutido, o fato de a cultura da subsidiária se apresentar próxima a do Brasil, é considerado um fator relevante na transferência de conhecimento, que favorece este processo, segundo Takeuchi e Nonaka (2008).

Logo, na medida em que as subsidiárias apresentam uma melhor compreensão ou similaridade com a cultura brasileira ou organizacional da matriz, maior será o compartilhamento de conhecimentos e práticas, como observado pelos valores representativos no conglomerado 1. Este processo dinâmico de conversão do conhecimento fará com que a subsidiária compreenda cada vez mais o negócio da multinacional e, por isso, poderá vislumbrar oportunidades para otimização dos recursos, caracterizando-se como iniciativa interna.

Para essas subsidiárias, Birkinshaw (1995) destaca dois atributos essenciais: credibilidade e bom relacionamento com a matriz e, defesa dos esforços individuais da unidade.

Esses atributos podem estar relacionados a aspectos contextuais dos países nos quais as subsidiárias estão localizadas, como o alto investimento em tecnologia, pesquisa e inovação; o que pode ser uma justificativa para a alta iniciativa interna. Como nestes países o nível de desenvolvimento econômico é alto, é reconhecido o elevado grau de contribuição e evolução tecnológica nos processos organizacionais, o que faz com que as multinacionais brasileiras 
sejam favorecidas. À medida em que a unidade internacional brasileira está inserida neste ambiente e há reconhecimento destas iniciativas pela matriz, contribui para o aprendizado e desenvolvimento organizacional da multinacional brasileira.

Em relação aos setores de atuação, é interessante comparar o tipo de atividade das unidades com os resultados da iniciativa. No conglomerado 1 (Iniciativa de Reconfiguração), existe uma maior incidência de unidades montadoras de sistemas e de serviços e tecnologia da informação, caracterizadas pela necessidade do contato direto e frequente com a matriz brasileira, para alinhamento dos processos produtivos ou entre os colaboradores. Este fato justifica a média e a média alta interação por meio da transferência de conhecimento entre a matriz e a subsidiária e a alta iniciativa interna.

Entretanto, as subsidiárias do conglomerado 3, nomeadas neste estudo como Iniciativa no Mercado Local, conforme a proposta de Birkinshaw (1995), indicam que tanto a transferência de conhecimento em ambos os sentidos (matriz versus unidades) quanto a cultura são relevantes para as iniciativas destas. Ressalta-se, no entanto, mais do que interações nos contextos corporativos, as redes de contato locais com clientes, fornecedores e associações tornam-se fundamentais para a busca de oportunidades de negócios, caracterizadas como iniciativa externa.

O alto nível de autonomia e presença no ambiente local, o alinhamento com os objetivos estratégicos da multinacional e, criatividade e espírito empreendedor da unidade são para Birkinshaw (1995) os fatores chaves para o sucesso para as subsidiárias com Iniciativa no Mercado Local.

Em relação às características complementares, as subsidiárias do conglomerado 3 estão localizadas predominantemente na América Latina, sendo a maioria atuante com insumos básicos.

Por um lado, observou-se que o valor para a cultura foi médio, sendo coerente com as semelhanças que os países da América Latina apresentam com a cultura brasileira. A proximidade cultural é um fator relevante para o processo de transferência de conhecimento entre as unidades, ocasionando um melhor desempenho local. Por outro lado, o setor de atuação, insumos básicos, requer uma alta interação com os agentes do contexto local, pois se apresenta como intermediário na cadeia produtiva, propiciando uma maior iniciativa externa. Logo, as multinacionais brasileiras que atuam neste setor, para venderem seus produtos, 
precisam interagir constantemente com os seus clientes e o mercado local, o que pode gerar uma alta iniciativa externa.

Por fim, as subsidiárias do conglomerado 2, denominadas neste estudo de Iniciativa Incipiente, são unidades que tendem a apresentar culturas similares a do Brasil, mas a transferência de conhecimento é baixa tanto da matriz para a subsidiária, quanto no sentido oposto e uma das consequências destes processos, ainda que em baixa intensidade, é que as unidades internacionais não dominam bem o negócio da corporação ao ponto de poderem propor iniciativas.

As subsidiárias deste conglomerado localizam-se principalmente na América Latina e África, regiões formadas por países com baixo desenvolvimento técnico e tecnológico, apesar de certa similaridade cultural com o Brasil.

A justificativa mais provável para a baixa iniciativa das unidades deste grupo é o setor de atuação, principalmente aquelas que atuam com recursos naturais, agronegócios e mineração. Nestes casos, os processos de trabalhos são muito bem desenhados e padronizados, requerendo pouquíssimo aperfeiçoamento. Também, as multinacionais brasileiras que atuam nestes setores, na sua maioria, possuem demandas previamente definidas nos países, não necessitando de uma atuação presente com as redes de contato locais, fomentando oportunidades de negócios.

Logo, evidencia-se que cada subsidiária inicia seu processo de iniciativa levando em consideração os recursos que detém, tanto internamente quanto do contexto que está inserida. No caso da iniciativa interna, trata-se da alta transferência de conhecimento principalmente da matriz para a subsidiária e a sua proximidade cultural; enquanto que na iniciativa externa, além da transferência de conhecimento, busca otimizar suas redes de contato locais.

Provavelmente, a partir do momento em que essas subsidiárias dominarem suas iniciativas, as quais podem ser internas ou externas, dependendo de outras condições favoráveis, tais como do contexto local do país, poderão partir para o desbravamento das complementares, fomentando os dois tipos de iniciativa, na busca pela Iniciativa de Extensão de mandato (BIRKINSHAW, 1995), ou seja, unidades que procuram construir um mandato em vigor ou capacidade comprovada para atender a uma demanda internacional do produto ou oportunidade de mercado. 


\section{6 - APRESENTAÇÃO E ANÁLISE DOS RESULTADOS QUALITATIVOS}

Conforme explicado no capítulo de metodologia, este estudo caracteriza-se como uma abordagem de métodos mistos, combinando técnicas quantitativas e qualitativas, utilizando-se a estratégia sequencial explanatória (CRESWELL, 2003).

Visto que o propósito desta estratégia é utilizar os dados qualitativos para auxiliar na explicação e interpretação dos resultados no estudo quantitativo preliminar (CRESWELL, 2003); este capítulo constitui-se pelos resultados do estudo de campo realizado na Weg S.A., multinacional brasileira, buscando compreender a transferência de conhecimento e os aspectos culturais na relação entre matriz e subsidiária, destacando como estas questões influenciam a iniciativa da subsidiária.

Para análise, diversas e complementares fontes de dados foram utilizadas: dados secundários, as entrevistas com os gestores de comércio exterior e os questionários respondidos pelos diretores locais das filiais da Weg, conforme detalhados no capítulo dos procedimentos metodológicos.

O capítulo está estruturado em cinco seções, sendo que nas duas primeiras são apresentadas informações gerais da empresa e o seu processo de internacionalização. Na terceira seção, os resultados das entrevistas com os gestores de exportação da matriz são apresentados e analisados, representando assim, a visão da matriz brasileira; enquanto que na seção seguinte são relatados os resultados coletados por meio de questionários respondidos por oito diretores de filiais (escritórios e plantas) da Weg, correspondendo a visão das subsidiárias.

Por fim, são analisados os resultados em conjunto à luz das teorias de internacionalização e o modelo proposto no presente trabalho, relacionando os três construtos principais: iniciativa da subsidiária, transferência de conhecimento e cultura. 


\section{1 - A Empresa WEG S.A.}

A Weg foi fundada em 1961 por um eletricista, um administrador de empresas e um ferramenteiro; cujas letras iniciais formam o nome da empresa, que significa caminho, em alemão. Sua sede está localizada na cidade de Jaraguá do Sul, em Santa Catarina, sendo os geradores, transformadores e motores elétricos seus os principais produtos. Atua também com equipamentos e projetos para automação, geração e transmissão de energia e, tintas especiais e customizadas (SCHMITZ, 2001).

A empresa possui 8 fábricas no Brasil e 22 filiais espalhadas em diversos países, sendo 6 unidades fabris (três na Argentina, duas no México, China e Portugal) e os demais escritórios comerciais. Além destes, possui mais de 100 distribuidores no mundo.

A Weg encontra-se em plena expansão e crescimento tanto no mercado interno quanto no externo e, mediante aos muitos investimentos, no primeiro semestre de 2010, adquiriu a Zest Group, na África do Sul, que possui $51 \%$ do mercado local de motores e foi durante 30 anos parceira e representante da Weg no país; além da ampliação da sua participação (60\%) na Voltran S.A., fabricante mexicana de transformadores e, a aquisição da Instrutech no Brasil. Como investimento direto (greenfield), está implantando uma unidade de fabricação na Índia e uma unidade em Linhares (Espírito Santo - BR), cujo foco é a produção de motores comerciais, ambas com início das operações previsto para 2011.

As ações da Weg começaram a ser negociadas na Bolsa em 1971, apresentando no final do primeiro semestre de 2010, um valor superior a 620 bilhões de ações nominais, com a composição acionária formada pela Weg Participações e Serviços S.A., com 50,96\%; a família dos fundadores, com 14,41\%; os administradores, com 1,05\% e, outros investidores com $33,58 \%$. 


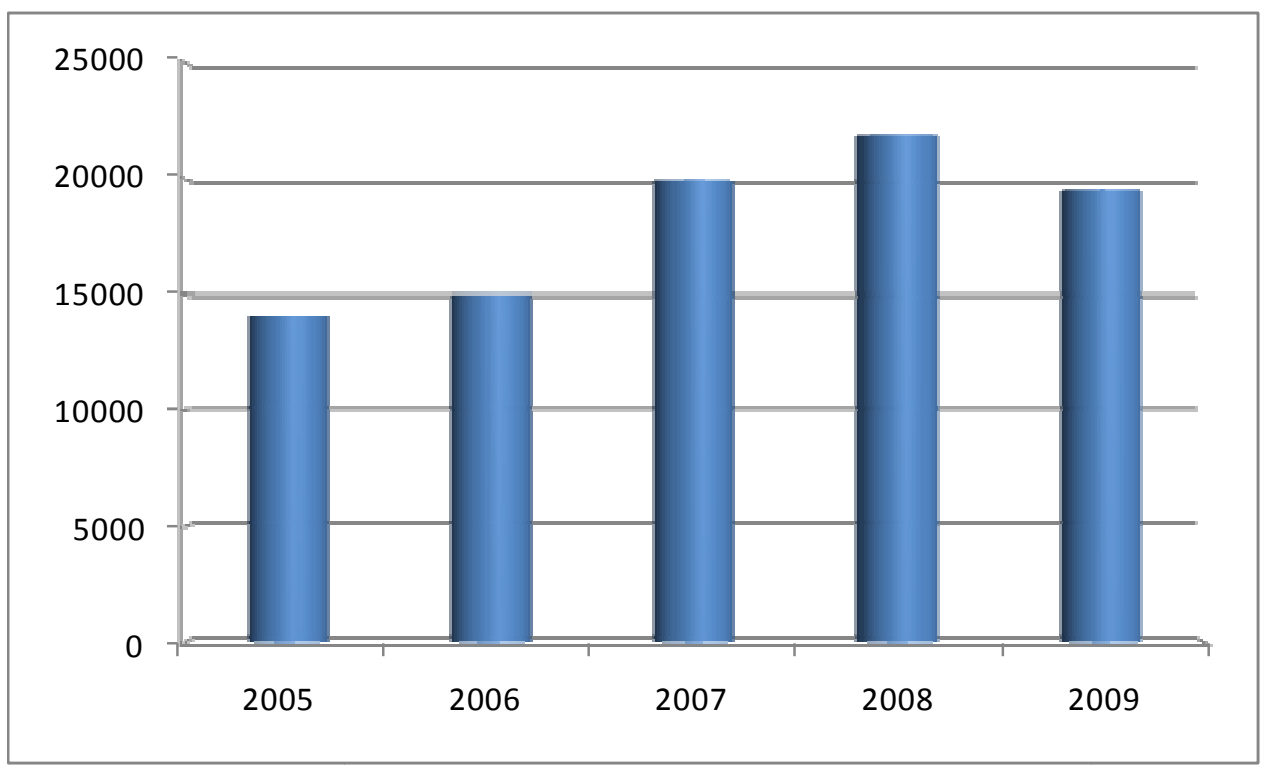

Gráfico 4 - Número de colaboradores da Weg S.A. no âmbito mundial

Fonte: site Weg S.A.

Em relação ao número de empregados no contexto mundial, apesar de pequenas oscilações nos últimos anos (

Gráfico 4), a Weg apresenta um quadro de aproximadamente 20.000 colaboradores atuando nas unidades nacionais e internacionais. Com o crescimento contínuo, este número tende a se tornar mais expressivo.

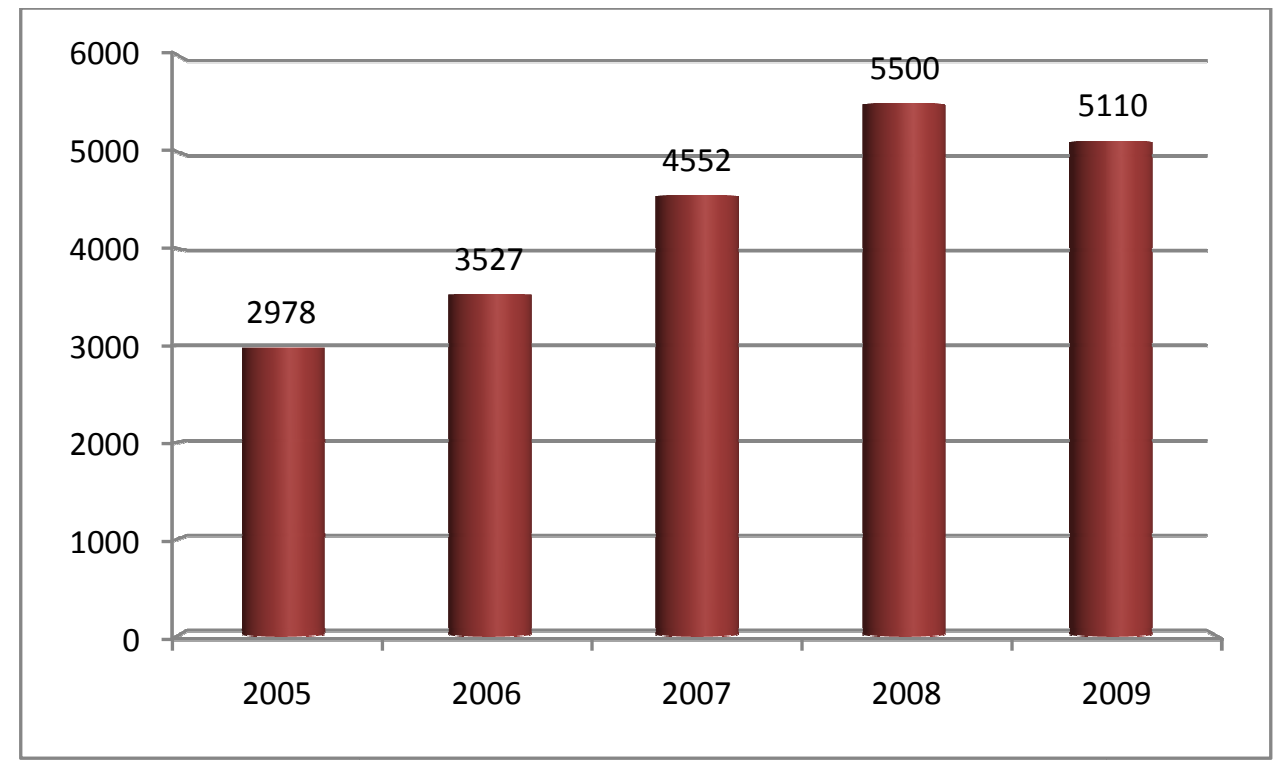

Gráfico 5 - Faturamento anual da Weg S.A. (em milhões de R\$) Fonte: site Weg S.A.

$\mathrm{O}$ aumento do faturamento da Weg nos últimos anos (Gráfico 5) reflete diretamente a sua atuação no mercado nacional e internacional, sendo que houve uma pequena queda em 2009, decorrente da crise mundial iniciada no final do ano anterior. Nos últimos anos, a participação 
do exterior no faturamento da empresa tem aumentado, representando em meados de 2010, $32 \%$ sendo $12 \%$ oriundos da América do Norte, $8 \%$ da Europa, 3\% da África, 3\% da Ásia e $6 \%$ da América do Sul.

Segundo Ranking das Transnacionais Brasileiras, desenvolvido pela Fundação Dom Cabral (2010), a WEG encontra-se na décima sexta colocação entre as empresas brasileiras mais internacionalizadas. Como $17 \%$ dos seus ativos estão no exterior, em relação a este quesito, a WEG se encontra na décima primeira posição do ranking. A receita oriunda do exterior representa $21 \%$ do total, atribuindo-se o décimo terceiro lugar na colocação.

O departamento de Pesquisa e Desenvolvimento (P\&D) é centralizado na matriz. Na matriz, há um comitê técnico, formado por engenheiros, que avaliam todas as novas sugestões e viabilidades de produtos. Este comitê anualmente se reúne com professores e pesquisadores de universidades renomadas nacionais e internacionais com o intuito de conhecer as tendências tecnológicas.

As filiais variam em porte e número de colaboradores, dependendo diretamente da atuação no país e o seu crescimento. Os colaboradores são, na maioria, engenheiros ou profissionais da área de motores.

A gestão de pessoas é descentralizada, permitindo que cada filial tenha autonomia na definição das suas políticas e processos. A Weg incentiva intercâmbios entre os colaboradores, incluindo os mais jovens contratados ou os participantes de programas de trainees (MURITIBA, 2009); no entanto, os valores da empresa são únicos para todas as unidades, nacionais e internacionais:

companhia humana: valorização e promoção do desenvolvimento pessoal dos colaboradores;

$>$ trabalho em equipe: proporcionando o compartilhamento de conhecimentos $\mathrm{e}$ experiências, visando beneficiar os clientes;

$>$ eficiência: busca pela melhoria continua nos produtos e processos;

$>$ flexibilidade: mudanças e melhorias para atender aos clientes;

$>$ inovação: promoção de um ambiente que propicie novas ideias e tecnologias;

$>$ liderança: tornar-se referência no relacionamento com clientes. 


\section{2 - Processo de internacionalização}

A Weg iniciou o seu processo de internacionalização no início da década de 70 , por meio de exportações para a Argentina e Paraguai, seus países vizinhos.

Naquela época, a empresa não tinha um interesse muito grande em exportação, mas com o passar dos anos percebeu a sua importância e começou a abrir distribuidores/revendedores em diversos países no mundo, os quais adquiriam os produtos da Weg, estocavam e distribuíam para o país inteiro.

Em um momento posterior, a empresa resolveu criar as filiais visto que muitos distribuidores não se interessavam em investimentos que pudessem oferecer novos produtos, conforme relato do entrevistado 1:

[...] Estava vendendo bem motores, mas nós queríamos que ele (o revendedor/distribuidor) vendesse automação, por exemplo; que exigiria dele contratar mais especialista, ampliar o negócio, como colocar uma nova loja, um estoque mais amplo. Então ele não queria investir tanto naquele negócio, porque ele já estava satisfeito com o primeiro negócio dele [...]. (Gerente de exportação da Weg)

Com a criação da filial, em países com grande potencialidade, a empresa obteve um crescimento muito mais acelerado quando comparado a época de somente distribuidores.

Com a decisão de possuir filiais produtivas no exterior, o crescimento da Weg foi muito maior do que as fases anteriores. O resultado é que ao final dos anos 2000, existem diversos distribuidores espalhados pelo mundo, mas nos pontos mais estratégicos a empresa possui filiais, que representam $70 \%$ do total em vendas anuais. Conforme relatado pelo entrevistado 2, o papel da filial realmente é a linha de frente com o cliente [...].

A partir de 2000, com a aquisição de fábricas no exterior, a Weg assume efetivamente o posto de multinacional brasileira.

Para a abertura de uma nova filial da Weg no mundo, segundo o Entrevistado 1 o principal critério é o "potencial do mercado local", ou seja, deve-se realizar uma análise criteriosa sobre o ambiente, principalmente em relação aos concorrentes locais e futuros, bem como a possibilidade de compra dos produtos da empresa pelo mercado local e aspectos relativos a logística, que favoreçam a instalação de uma filial devem ser questionadas. Existem alguns 
casos em que os representantes (distribuidores) se tornam filiais da empresa, principalmente quando há possibilidade de compra por parte da concorrência.

Até meados de 2010, a Weg possuía três fábricas na Argentina, uma em Portugal e uma na China. Alguns anos anteriores, a aquisição da unidade no México serviu como estratégia de ponta para a conquista do mercado de energia dos Estados Unidos, enquanto nas novas unidades na África do Sul e na Índia, o principal objetivo é o de atuar com presença mais direta nos mercados africano e asiático, respectivamente.

Tanure et al (2007) destacaram que a internacionalização da Weg era uma estratégia presente na herança administrativa, percebido como importante pelos seus fundadores já na década de 70, conforme o relato de um deles: "a Weg entendeu logo que não precisava crescer e se fortalecer para depois começar a exportar, uma vez que exportar era parte essencial do processo de crescimento" (STANGE, 2000 apud TANURE et al, 2007, p. 203).

Logo, esse resgate inicial sobre a Weg, bem como seu processo de internacionalização é importante para a compreensão, reflexão e análise acerca ou dos aspectos relacionados ao objetivo deste estudo, os quais são devidamente aprofundados a seguir.

\section{3 - Visão da matriz brasileira}

Nesta seção, apresenta-se a visão da matriz brasileira sobre o processo de transferência de conhecimento entre as unidades da multinacional, a percepção das diferenças culturais e seus impactos, além da atuação das subsidiárias na busca de novas oportunidades de negócios, ou seja, a iniciativa.

Para isso, são utilizados como subsídios para a análise os resultados das entrevistas semiestruturadas com os gestores de comércio exterior da Weg, realizadas em junho de 2010. Em relação ao perfil dos entrevistados, ambos são engenheiros de formação, há mais de 20 anos na empresa, ocupando diferentes cargos e funções. Cabe ressaltar que o entrevistado 1 (E1) atuou por um período no exterior, realizando análises de mercado e projetos de viabilidade de novas unidades.

Visando facilitar a compreensão e explanação, os resultados relativos a cada construto do estudo (transferência do conhecimento, cultura e iniciativa) são apresentados separadamente e sequencialmente. 


\subsection{1 - Transferência de conhecimento entre as unidades}

As entrevistas com os gestores indicam que a transferência de conhecimento entre as unidades não é tão formalizada; sendo que o principal mecanismo utilizado é o fluxo de pessoas, tanto da matriz para as unidades, quanto destas para a matriz.

No início de uma nova operação no exterior, sempre há presença de brasileiros, mesmo que seja por um curto período de tempo, conforme relato do entrevistado 2: "é muito comum que se tenha uma nova filial e um brasileiro [...] com o passar do tempo isso muda, pode se ter pessoas locais assumindo, porque isto é importante que aconteça [...]".

Com a criação e/ou aquisição de novas plantas no exterior, existe uma preocupação por parte da matriz em aprimorar os processos de transferência de conhecimento e experiências, visando facilitar a operação produtiva nas unidades de produtos projetados no Brasil, ressaltado pelo entrevistado 2:

é fundamental que exista essa troca de experiência para que os mesmo erros que fazemos aqui (na matriz) não sejam feitos lá fora. Isto é na verdade um grande desafio que nós temos pela frente, de aumentar essa troca de conhecimento. E2

Outro mecanismo de transferência evidenciado é a visita de colaboradores das filiais à matriz, os quais permanecem no Brasil durante uma semana, conhecendo os processos de trabalho e identificando suas possibilidades para implantação na sua unidade de origem. Nestas viagens, os colaboradores conhecem as fábricas brasileiras e participam de treinamentos sobre os produtos que são oferecidos pela unidade no mercado externo.

Há uma preocupação por parte da direção da Weg em não impor regras e normas às filiais. Por exemplo, a multinacional está implantando um sistema integrado de gestão em todas as unidades de forma gradativa, conforme as capacidades e necessidades de cada filial, como enfatizado pelo E1 “[...] uma rampa suave, não é nada assim brusco".

A matriz se preocupa com a orientação sobre a filosofia organizacional, no que diz respeito a forma de atendimento ao cliente, pois o mais importante deve receber maior atenção, ou o segmento do negócio que deve ser fortalecido e priorizado no momento. Não há uma preocupação em estabelecer regras e processos de trabalho, tais como horários ou 
procedimentos, desde que a unidade esteja apresentando retorno, com o crescimento previsto pela alta direção da empresa. Caso contrário, a matriz poderá intervir na forma de gestão da unidade.

As unidades enviam mensalmente relatórios à matriz brasileira, sendo esta uma dos mecanismos mais formais de transferência de conhecimento, tornando-o explícito e mais fácil de ser compartilhado.

As unidades compartilham conhecimentos e práticas, mas também informalmente. Uma das mais importantes ações formais por parte da Weg para transferência de conhecimento entre todas as unidades mundiais é uma reunião anual, que na maioria das vezes, é realizada no Brasil. Trata-se de uma reunião geral de benchmarking, onde cada uma das filiais/plantas expõe seus resultados, tanto positivos quanto os negativos e indica o que precisa ser melhorado, ou seja, um follow-up do ano anterior e um planejamento estratégico para os próximos períodos. O E1 acredita que este seja “[...] o momento de todos partilharem $e$ aprenderem com a experiência dos outros [...]".

Além da reunião anual, acontecem as reuniões regionais que propiciam discussões mais pontuais e locais, sendo conduzidas pelos três diretores regionais, dois brasileiros oriundos da Weg matriz e um chinês.

Também, segundo E1 o contato telefônico entre os diretores das filiais (escritórios e plantas) de uma mesma região é frequente, em alguns casos, são diárias, visto que o mesmo cliente da Weg pode estar em diferentes países.

$\mathrm{O}$ processo de expatriação de brasileiros é comum no início do processo de internacionalização da Weg, na implantação de uma nova filial e, com o passar do tempo, a empresa identificou que esta prática não era boa para todas as áreas, como a de vendas, que deveria ser composta por colaboradores nativos, pelo fato de fazerem parte da cultura local e compreenderem melhor os clientes, como exposto por um dos entrevistados:

[...] a atuação em vendas, realmente, é bem focado na relação de pessoa para pessoa, não é a empresa que vende, é a pessoa que vende. Então, é muito mais fácil para alguém local vender para o outro do local, do que alguém de fora que chegue lá... Até aprender a cultura local, mesmo que fique lá 10 anos aprendendo a cultura, conhecendo o que é certo ou errado, não será a mesma coisa... Até na hora de contar uma piada, de entender uma piada, às vezes, tem alguns jargões que você não vai entender e não consegue convencer [...]. E1 
O relacionamento com os colaboradores estrangeiros, de outras filiais, é visto como um processo fácil no contato via telefone ou email, até mesmo pelo fato de existirem na matriz, colaboradores que dominam diversos idiomas. Além disto, um dos entrevistados acredita que o brasileiro tenha a habilidade de buscar soluções e estar aberto, acessível, facilitando o entrosamento entre as partes.

De uma maneira geral, os entrevistados acreditam que o relacionamento entre brasileiros e estrangeiros nas filiais não apresente grandes problemas, enfatizam que a presença dos brasileiros é reconhecida como importante pelas unidades, pois facilita o processo de comunicação com a matriz, além destes indivíduos geralmente possuírem domínio técnico sobre os produtos e processos.

Em relação às barreiras na transferência de conhecimentos, os representantes da matriz entrevistados não percebem a ocorrência. No entanto, relatam que é mais perceptível no nível regional, por exemplo, na Europa, pelos fatos históricos de divisões e guerras entre países, nos quais existe uma postura muito bairrista e patriota, defendendo seus próprios países; mesmo com a União Européia.

O entrevistado 2 acredita que algumas filiais são mais resistentes a certas determinações da matriz, mas acredita que seja muito mais decorrente da característica da pessoa, do gestor, do que da cultura do próprio país.

Logo, observa-se que para a matriz brasileira, os processos de transferência de conhecimento ocorrem principalmente por meio de expatriados brasileiros para as unidades e de visitas técnicas dos colaboradores destas para a matriz; valorizando-se assim o contato pessoal e os mecanismos de socialização do conhecimento. Também, destaca-se como estratégia de transferência de conhecimento os encontros anuais de todas as unidades.

\subsection{2 - Cultura organizacional da WEG e diferenças culturais}

No processo de aquisição de uma filial ou de uma planta, existe uma preocupação por parte da Weg em respeitar as pessoas e a cultura local, buscando evitar reações e choques culturais, visto que 
tem uma filosofia de tentar crescer o mais rápido possível e quando tem uma aquisição de uma empresa no exterior ou abertura de uma filial se respeita muito a cultura do país, a cultura das pessoas [...]. E1

Nesses processos de aquisições, a expatriação de brasileiros para as filiais ou plantas é a principal forma de transferência da "filosofia da matriz" (E1) para a unidade e, também de aprender a cultura e as práticas de sucesso da empresa local. Para a Weg, o diferencial da expatriação de brasileiros às filiais é o fato destes indivíduos conhecerem profundamente a cultura da empresa, bem como os processos de trabalho que precisam ser implantados nas unidades, conforme as palavras do entrevistado 2:

\begin{abstract}
A vantagem desta pessoa conhecer como funciona a nossa estrutura aqui no Brasil, porém é importante também que é se contratem estrangeiros, até pra que nós aqui (na matriz) possamos aprender com novas visões. Num primeiro momento, principalmente, vejo como muito importante que sejam brasileiros porque conhecem a cultura da empresa [...] a cultura de se fazer as coisas planejadas, da simplicidade. E2
\end{abstract}

Uma das características da cultura da Weg é a valorização do colaborador. O E1 mencionou uma frase de um dos fundadores da empresa, Sr. Eggon João da Silva, e que permeia nos dias atuais: "Se faltam máquinas, você pode comprá-las. Se não há dinheiro, você toma emprestado. Mas homens, você não pode comprar nem pedir emprestado. E homens motivados por uma ideia são a base do êxito".

$\mathrm{Na}$ linha de valorização das pessoas, outra prática existente na empresa é a gestão participativa, em todos os níveis, tanto no Brasil quanto nos demais países. Qualquer colaborador pode propor uma sugestão ou melhoria, que será analisada pelos comitês locais.

Esta cultura de respeito ao colaborador e as particularidades de cada filial/planta, segundo o E1 é uma característica muito presente na cultura da Weg e que facilita a gestão nas unidades, na medida em que "[...] valoriza o que as duas partes têm de bom e evita-se o conceito de que eu [matriz] estou certo e você [unidade] está errado, então são dois pensamentos diferentes [...]", buscando identificar o que cada um pode contribuir para o outro.

Outra característica da cultura organizacional da Weg é o relacionamento aberto, entre níveis hierárquicos distintos e entre as unidades nacionais e internacionais, promovendo uma comunicação direta, com diálogos constantes. 
Segundo as entrevistas, o fato de a matriz não impor as regras e sim discuti-las e defini-las em consenso nas reuniões anuais, torna o processo de disseminação e aceitação das diretrizes mais facilmente pelas unidades a curto prazo do que se a alta direção determinasse regras a serem cumpridas.

"Os resultados são impostos, os processos não" (E1). A Weg expõe as diretrizes básicas e cobra o resultado, como o aumento de vendas, oferta de outros produtos, atendimento a determinadas empresas, mas a forma como a unidade irá atingir tais resultados não é determinada em detalhes pela matriz, desde que se respeite a filosofia e os princípios básicos da empresa.

Em relação a influência das culturais locais dos países na gestão das filiais, em alguns casos, a compreensão das suas características principais se torna fundamental. O entrevistado 1 ressaltou o caso da Índia, no qual as vendas ocorrem dentro das castas e por isso a atuação de colaboradores locais é de fundamental importância, destacado no discurso do gerente de exportação na matriz : "[...] se fôssemos aplicar o nosso sistema [brasileiro] lá hoje e fossemos trabalhar só com brasileiros lá também o resultado iria ser bem inferior [...]".

Muitas vezes, as diferenças culturais exigem uma postura mais flexível por parte da matriz. "É o caso do Japão que precisa de uma série de reuniões para que ele se convença do produto e compre", relata um dos representantes da matriz, "se olhar com a nossa visão hoje, é um pouco de exercício que a gente tem que fazer para esperar aquele tempo... novamente é a cultura daquele país e você tem que estar ambientado".

Também, nos processos de contato e negociação com as filiais, os colaboradores na matriz precisam se adequar constantemente às culturas locais, pois são bem diferentes, conforme enfatizado pelo entrevistado 2:

"[...] no dia a dia, durante os contatos, nós sempre temos que estar mudando a nossa chavinha. Opa, agora eu vou falar com um americano, agora eu vou falar com australianos, agora eu vou falar com um chinês... porque a maneira de se comunicar, a maneira de se entender as coisas é diferente $[\ldots . . . "$

O fuso horário é um aspecto da cultura que pode prejudicar o andamento das atividades e precisa ser considerado. É o caso da Austrália, conforme relato do E2: "se você deixa de dar 
uma resposta hoje no final da tarde e, responde amanhã de manhã, você perde um dia, porque o pessoal vai chegar lá e não vai ter a resposta e vai ter que esperar outro dia."

Assim, por meio das entrevistas com os representantes da matriz brasileira, acredita-se que as características da cultura organizacional da Weg são facilitadoras e impactam positivamente nas filiais, respeitando as diferenças e as particularidades de cada país, promovendo uma gestão local mais eficaz e eficiente.

\subsection{3 - Iniciativa das unidades}

De uma maneira geral, unidades no exterior (tanto filiais comerciais como as filiais produtoras) buscam identificar oportunidades no mercado local, por meio da interação com seus clientes, fornecedores e concorrentes. A partir de uma nova demanda de um cliente, a unidade comunica a matriz, o setor técnico, para verificar a possibilidade de atendimento.

Conforme relatado pelo entrevistado 1, é mais comum que essas iniciativas sejam oriundas das unidades da Europa ou Estados Unidos, devido principalmente ao alto nível de desenvolvimento tecnológico destes países e das exigências locais. Afirma "[...] não é nada pejorativo, mas a América Latina é mais seguidora... do que acontece nos EUA, do que acontece na Europa [...]”. O produto após ser lançado nos Estados Unidos, demora de um a dois anos para ser comercializado na América Latina. Isto acontece, “[...] não pelo fato da falta de capacidade das unidades, mas sim do mercado no qual está inserida, que demandará ou não novas tecnologias [...]”.

O reconhecimento dessas iniciativas das unidades acontece diariamente, após um retorno de um email ou solicitação de novos produtos. Acontece também por meio de viagens frequentes dos gerentes e engenheiros de aplicação às unidades estrangeiras, compreendendo de perto as necessidades do mercado local e as propostas desenvolvidas de atendimento.

O entrevistado 1 enfatiza que as oportunidades vislumbradas pelas filiais são "reconhecidas pela matriz na medida em que esta não mede esforços para verificar a viabilidade da proposta e a possibilidade de transformá-la em um negócio, caso se caracterizelapresente como rentável para a organização". 
Grande parte dos produtos da Weg é customizado conforme as solicitações dos clientes. A partir da identificação da necessidade na filial, esta contata a matriz solicitando orçamento e prazo de entrega. Geralmente, em dois dias a filial já detém todas as informações importantes para transmitir ao cliente.

Existem situações em que as filiais de uma mesma região entram em contato entre si, com o objetivo de atender à necessidade de um determinado cliente. É o caso das filiais localizadas na Europa que podem buscar auxílio na planta da Weg localizada em Portugal, ou utilizar o estoque de outra filial, quando lhes falta algo.

Nos países onde estão localizadas, as filiais representam a Weg perante instituições e associações, buscando sempre fortalecer relações que facilitem e promovam o crescimento e desenvolvimento da unidade naquele mercado local.

Entretanto, o desenvolvimento de novos produtos é bastante centralizado no Brasil. As filiais somente comercializam e identificam oportunidades de negócios, enquanto as fábricas no exterior possuem "certa liberdade de desenvolver produtos próprios, mas sempre existe um relacionamento muito grande com o Brasil para ver quais são até as estratégias e a viabilidade", expõe o entrevistado 2.

Desta maneira, percebe-se que existe um incentivo por parte da matriz para que as unidades vislumbrem oportunidades de negócios, principalmente no mercado local. No entanto, visto que o departamento de pesquisa e desenvolvimento da maioria dos produtos está centralizado no Brasil, as propostas de novos produtos/serviços ou mesmo daqueles customizados devem ser encaminhados pela unidade à matriz brasileira para análise de viabilidade técnica e financeira.

Assim, em relação à visão da matriz, o Quadro 29 apresenta uma síntese dos principais das principais características em relação a transferência de conhecimento, a cultura e a iniciativa da subsidiária. 
Quadro 29 - Sínteses sobre a visão da matriz da multinacional brasileira

\begin{tabular}{|c|l|}
\hline Dimensões & \multicolumn{1}{c|}{ Principais características } \\
\hline \multirow{3}{*}{$\begin{array}{c}\text { Transferência de } \\
\text { conhecimento }\end{array}$} & $\begin{array}{l}\text { - pouco formalizada } \\
\text { - o fluxo de pessoas é o principal mecanismo utilizado, sendo brasileiros expatriados (matriz } \\
\text { para subsidiária) e colaboradores estrangeiros (subsidiária para matriz) } \\
\text { - relatórios mensais enviados das unidades para a matriz } \\
\text { - reunião geral anual, no Brasil, com representantes de todas as unidades } \\
\text { - não há barreiras no processo de transferência de conhecimento no contexto corporativo } \\
\text { geral; regionalmente, pequenas dificuldades ocorrem }\end{array}$ \\
\hline \multirow{3}{*}{ Cultura } & $\begin{array}{l}\text { - respeito à cultura local e particularidades das unidades estrangeiras (processos flexíveis) } \\
\text { - expatriados brasileiros transferem a filosofia da matriz para as unidades } \\
\text { - cultura de valorização do colaborador e gestão participativa em todos os níveis } \\
\text { organizacionais } \\
\text { - alta influência da cultura local da subsidiária na área comercial }\end{array}$ \\
\hline uniciativa das & $\begin{array}{l}\text { - unidades estrangeiras identificam oportunidades de negócios nos mercados locais } \\
\text { - oportunidades vislumbradas pelas unidades de países com alto desenvolvimento } \\
\text { tecnológico } \\
\text { - reconhecimento das iniciativas e estudo de viabilidade pela matriz quando a proposta for } \\
\text { rentável } \\
\text { - desenvolvimento centralizado no Brasil } \\
\text { - atuação em rede das unidades estrangeiras na busca de oportunidades de negócios }\end{array}$ \\
\hline
\end{tabular}

\section{4 - Visão das unidades no exterior}

Contrapondo-se à seção anterior, nesta apresenta-se o ponto de vista das unidades no exterior. Para isto, utilizou-se os dados obtidos com as respostas dos questionários disponibilizados às filiais da Weg. Foram oito diretores participantes representando seis escritórios (Bélgica, Itália, Espanha, Austrália, Cingapura e Chile) e duas plantas fabris (Argentina e México). Salienta-se que todos são engenheiros elétricos, de nacionalidade distintas: um belga, um italiano, um espanhol e cinco brasileiros.

Novamente, como na seção da visão da matriz, a fim de facilitar a exploração dos resultados das unidades, estes são apresentados em subseções, conforme as variáveis de análise: aspectos culturais, transferência de conhecimento e iniciativa das filiais.

\subsection{1 - Aspectos culturais}

Todas as unidades respondentes possuem expatriados brasileiros, com exceção da filial na Espanha. No entanto, todos foram unânimes nas respostas sobre a satisfação dos 
colaboradores locais em trabalhar com profissionais brasileiros, devido algumas características culturais como enfatizado pelo diretor brasileiro da filial mexicana " $O$ mexicano gosta do brasileiro, nos consideram abertos e sociáveis, muito parecidos com eles próprios" e pelo diretor da filial australiana "Devido ao espírito cooperativo dos brasileiros e disciplina para o trabalho, há uma fácil integração deles com os funcionários locais".

Outro aspecto ressaltado pelos representantes das filiais foi a otimização na comunicação com a matriz quando existem brasileiros nas unidades, principalmente naquelas em que o idioma não é similar ao português, como o caso da Bélgica: "Ter o povo brasileiro trabalhando conosco é um trunfo. Permite nos comunicar melhor com Weg no Brasil e ter uma visão geral do ponto de vista brasileiro".

No entanto, para algumas filiais a presença de brasileiros é vista como algo natural, decorrente da origem da empresa, como indicado no depoimento do representante de Cingapura: "Não existem, a princípio, problemas na interação de asiáticos com brasileiros. Como a empresa é de origem brasileira, esta característica é vista com naturalidade".

É unânime a ideia de que, de forma positiva, existe a influência da cultura organizacional da Weg na gestão da unidade, principalmente no que diz respeito ao processo de comunicação e a gestão participativa tanto dos colaboradores nas respectivas unidades quanto destas perante a matriz, como pode ser observado nos relatos dos diretores:

Gestão participativa é algo novo na região, uma vez que a cultura asiática prega a obediência aos superiores. Porem com o tempo, os indivíduos percebem a abertura e tendem a participar, ainda que em velocidade e profundidade menos agressivas que a cultura latina. (Weg Cingapura)

Comunicação aberta (Weg Bélgica)

A cultura de gestão participativa, dando oportunidades de opinar na gestão é bastante valorizada (Weg México)

A filosofia de administração participativa da Weg contribui para a motivação dos funcionários. (Weg Austrália)

Sua cultura é bastante semelhante a nossa e é fácil a troca de experiências [...] (Weg Itália)

A abertura da matriz para a aprendizagem com as unidades, que se mostra atenciosa em entender a realidade e contextos locais, como afirma o Diretor da Weg Itália: “[...] Eles estão 
sempre disponíveis em aprender e crescer de acordo com a mentalidade européia" foi outro aspecto da cultura organizacional da Weg mencionado.

Ao serem indagados sobre como as características culturais brasileiras e do país hospedeiro influenciam a gestão da unidade, os representantes destacaram aspectos da cultura organizacional da Weg e os seus reflexos. "Por se tratar de uma filial brasileira sempre vai existir alguma influencia de atitudes e procedimentos oriundos do Brasil”, relatou o representante da Weg do Chile, enquanto que o do México enfatizou "A cultura da empresa é a de cumprir com as promessas, e o de participar ativamente nos projetos. Isto se reflete aqui”.

Por um lado, para os Diretores da Argentina e Austrália, o convívio das duas culturas tem um resultado produtivo, conforme é possível identificar nos discursos dos mesmos, respectivamente: "Como um complemento e como agente motivador" e "o Brasileiro com seu espírito dócil e cooperativo e extremamente disciplinado no trabalho e o Australiano com sua característica pratica e eficiente no trabalho, criam um mix perfeito para nosso ambiente de trabalho".

Por outro lado, o Diretor da Itália afirmou que "Não é realmente uma "influência" porque o uso de gestão local para trabalhar em autonomia total em respeito aos papéis locais. É claro que temos de seguir a sua política comercial, quando aplicável". Isto indica que o respondente não acredita que haja influência das culturas tanto brasileira quanto italiana na gestão da unidade, acredita que seja um resultado da postura e estrutura organizacional da matriz que permite e valoriza a autonomia local.

O fuso horário e a questão da dificuldade de comunicação, decorrente do idioma do país, foram aspectos destacados pelo respondente da Weg Espanha: "A diferença de tempo e a linguagem são semelhantes, mas às vezes, causam problema. Além disso, Weg no Brasil está liderando o mercado, enquanto em Espanha é quase um iniciante".

Assim, as unidades estrangeiras acreditam que a cultura organizacional da Weg reflete positivamente na administração local, principalmente pela comunicação aberta e a gestão participativa. Sinalizam também que os colaboradores locais possuem um bom relacionamento com os brasileiros e, demonstram que as diferenças culturais existem, mas são consideradas complementares, obtendo-se resultados produtivos. 


\subsection{2 - Transferência de conhecimento entre as unidades}

Para a transferência de conhecimento e práticas da filial para a matriz são utilizados diversos mecanismos, sendo que as viagens e treinamentos na matriz brasileira são as estratégias presentes para todas as unidades respondentes, como destacado em "o treinamento é um dos pontos fortes da empresa. Regularmente enviamos pessoal para treinamento na matriz" pelo representante do México.

A realização de reuniões com executivos brasileiros e o envio de manuais e relatórios para a matriz foram também mecanismos mencionados como freqüentes no processo de transferência de conhecimento; relatado pelo diretor da Weg Bélgica "Nos sempre recebemos visitas de executivos brasileiros".

O benchmarking ou a existência de um banco de melhores práticas entre todas as unidades e a matriz não parecem ser mecanismos de transferência de conhecimento frequentes na multinacional brasileira, apesar de evidências da sua realização informal, como comenta o Diretor da Weg México:

Não existe um benchmarking formal, mas de alguma forma se estabelece comparações, pois em um evento anual, reunião com todos os diretores de filiais com os executivos da casa matriz, há apresentação de casos de sucesso, além da premiação das melhores filiais em resultados. Com esta experiência se faz também transferência de conhecimento, o que cada um está fazendo de melhor pode servir para outra filial. (Weg México)

Para o representante da Argentina, o fluxo de conhecimento é mais presente no sentido da matriz para as unidades "Via de regra os conhecimentos vertem da matriz", visto que para o Diretor da Itália a matriz brasileira tem se preocupado em aprimorar os mecanismos, conforme seu discurso "Eles estão melhorando todos os mecanismos".

Em relação às barreiras no processo de transferência de conhecimentos da filial para a matriz, somente o representante da Argentina relatou a existência de distorções na transmissão das atividades devido à estrutura hierárquica na multinacional ao comentar que " $o$ desenvolvimento da matriz está muito acima da filial, dificultando a transferência de praticas da filial para matriz. A matriz dita normalmente as regras do jogo, mas respeita as praticas locais que não ferem os princípios da matriz." 
Outras dificuldades no processo de transferência de conhecimento, relatadas pelos diretores das unidades dizem respeito ao tempo de atuação da filial e aos aspectos subjetivos, como atitude e comportamento dos indivíduos. Com o decorrer do tempo, após o início ou aquisição de uma nova unidade, as relações entre esta e a matriz tornam-se mais maduras e as barreiras, antes existentes, diminuem paulatinamente; conforme relatado pelo representante da Espanha: "no início existiam algumas dificuldades, com o tempo foram desaparecendo".

Para o representante da Itália, "às vezes é difícil de transferir a atitude "européia", que muitas vezes está em contradição com a da matriz. Normalmente eles [a matriz] nos acompanham, melhorando o reconhecimento", ou seja, a visão européia se distingue da brasileira, de forma que a matriz se esforça no sentido de compreender a realidade local, acompanhando as ações da unidade, ocorrendo um aumento do reconhecimento desta pela multinacional.

Entretanto, para o diretor da Weg México não existem obstáculos na transferência de conhecimento da unidade para a matriz: "não há barreiras nem dificuldades. $O$ relacionamento é aberto, sem travas".

Portanto, em relação à transferência de conhecimento, as unidades acreditam que ocorra em maior número no sentido da matriz para a subsidiária, do que no contrário. No entanto, destacam que as visitas e treinamentos na matriz são excelentes mecanismos de transferência de conhecimento em ambos os sentidos. Acreditam, também, que este processo se torna mais eficiente com o amadurecimento da unidade ao longo do tempo.

\subsection{3 - Iniciativa das unidades}

Todas as unidades participantes da pesquisa relataram que buscam identificar novas oportunidades de negócios para a multinacional como um todo, destacando a proximidade com os clientes locais, buscando identificar suas necessidades e atender o mercado, como se pode observar nos relatos:

Informando novas evoluções e necessidades do mercado (Weg Bélgica)

Este é o maior papel da unidade, identificar oportunidades e procurar realinhar as estratégias para tirar o maior proveito possível dos pontos fortes da empresa (Weg Cingapura) 
O pouco tempo de existência da unidade também parece ser um condicionante para promissores negócios, é o que relata o representante da unidade do Chile: "Como a filial aqui existe há sete anos, existem áreas de negócios pouco exploradas".

No caso de clientes globais, as filiais buscam um atendimento em parceria entre as unidades, como exposto pelo diretor da Weg México:

Países onde existe forte atividade primária são geradores de oportunidades para outras filiais venderem. Um país tem o usuário do equipamento, a empresa de engenharia está em um segundo e os fabricantes de equipamentos em terceiros ou mais países. Freqüentemente, a filial gera oportunidades para outros países/filais. (Weg México)

Em relação às redes locais, todos os respondentes indicaram que a unidade possui contato direto com os clientes e associações setoriais, como forma de os conhecerem e compreenderem melhor o mercado, bem como seus concorrentes:

Os contatos com clientes e potenciais clientes sempre serão importantes para o crescimento dos negócios da Weg aqui no Chile. (Weg Chile)

Estas são as fontes naturais de negócios. (Weg Argentina)

Sem duvida os atuais clientes são sempre potenciais geradores de novos negócios [...] e as associações setoriais, com informações sobre novos investimentos ou projetos [...] (Weg México)

Nossa atividade é puramente comercial e nós nos baseamos no negócio do cliente ligado diretamente com a nossa organização comercial. (Weg Itália)

As filiais também possuem contato direto com entidades governamentais e fornecedores nos seus países de origem, como atestam as palavras do Diretor do México: "fornecedores podem entregar informações de concorrentes (também seus clientes) ou ainda comentar sobre algum potencial negocio de conhecimento. As entidades governamentais [...], a existência ou criação de eventuais linhas de financiamento". Cabe salientar que, além dos contatos referenciados, o Diretor da Bélgica explicitou que sua unidade mantém estreito relacionamento com universidades.

Ao serem indagados se o processo de transferência de conhecimento entre a matriz e a unidade facilita ou dificulta a identificação de novas oportunidades de negócios, todos 
responderam positivamente, com exceção do diretor da Argentina que relatou: "nem facilita nem dificulta. Ocorre naturalmente".

No entanto, apesar de não indicar que o processo de transferência de conhecimento possa dificultar o desenvolvimento de novas oportunidades de negócios, o representante da Itália indicou que às vezes pode existir alguma demanda que exija uma aplicação mecânica muito rara e específica, pouco conhecida pelo Departamento de Engenharia. Neste caso, principalmente quando não há interesse da matriz no desenvolvimento do produto, por não fazer parte do foco da empresa, visto que a oferta é declinada.

$\mathrm{Na}$ identificação de oportunidades de negócios, o processo de transferência de conhecimento parece ocorrer em todos os sentidos, ou seja, tanto da matriz para as unidades quanto destas para a matriz e demais filiais. A interface da unidade com a matriz é realizada pelo Departamento de Vendas, que trabalha estreitamente com o Departamento de Engenharia, pois a maioria das oportunidades de negócios visualizadas está relacionada ao desenvolvimento de novos produtos, como se pode perceber nos discursos:

Existe um departamento criado na casa matriz para administrar as informações e gerenciar os interesses de cada filial. Quando se identifica uma oportunidade e a informação é transmitida a este departamento, a mesma informação é entregue a todos os potencialmente envolvidos no projeto. Não apenas entregamos, mas também recebemos informações sobre oportunidades de negócios na nossa área de atuação. (Weg México)

Existe uma rede de informações formal que é usada por todas as filiais no exterior para repartir informações sobre oportunidades de negócios entre filais e também com a matriz. (Weg Austrália)

Facilita, pois algumas experiências já foram feitas no Brasil e, portanto podem servir de guia para filial, mas nunca se esquecendo da cultura e costumes locais. (Weg Chile)

Sobre o reconhecimento da matriz das oportunidades de negócios evidenciadas pelas filiais, houve uma unanimidade nas respostas indicando a existência. As filiais possuem liberdade para sugerir o desenvolvimento de novos produtos ou a identificação de diferentes segmentos de atuação; sendo estes pontos de vistas recebidos de forma favorável pela matriz brasileira, conforme relatado nos questionários: 
Como somos nós que estamos constantemente em contato com o mercado local, os comentários e pontos de vista emitidos pela filial sempre são levados em consideração. (Weg Chile)

Não poderia ser diferente. (Weg Argentina)

De forma geral há o reconhecimento e compensação, através de políticas estabelecidas (regras). (Weg México)

São reconhecidas sugestões para desenvolvimento de novos produtos e identificação de novos segmentos de mercado. (Weg Austrália)

Eles são $100 \%$ confiantes na nossa capacidade e sempre disponível para apoiar-nos. (Weg Itália)

No entanto, o reconhecimento das oportunidades pela matriz existe, mas não necessariamente é um processo automático e rápido, enfatiza o Diretor da Weg da Bélgica “... é preciso tempo para chegar às conclusões".

Outro aspecto destacado na relação entre a transferência de conhecimento e o processo de identificação de oportunidades de negócios é a presença de brasileiros nas unidades, o que otimiza a comunicação entre as partes, e o conhecimento sobre a Weg e o seu negócio, como destacado pelo representante do México: "quando os executivos das filais são brasileiros expatriados, há comunicação e visão global da empresa, ação pelo bem comum é facilitada."

Existe também uma percepção do representante da filial argentina de que tanto a transferência de conhecimento quanto dos processos de trabalho ocorre muito mais no sentido da matriz brasileira para as unidades, do que no contrário: "há muito mais influência da matriz na filial do que o reverso".

Assim, as unidades internacionais da Weg buscam oportunidades de negócios, principalmente no mercado local, por meio das redes de contato com clientes, fornecedores, associações e instituições, reconhecendo que a iniciativa das unidades é facilitada pela existência da transferência de conhecimento entre as subsidiárias e a matriz, principalmente no momento desta reconhecer tais ações e empreendimentos.

Logo, o Quadro 30 mostra o ponto de vista das subsidiárias em relação às principais características do processo de transferência de conhecimento, a percepção sobre a influência da cultura na gestão da unidade, bem como sua iniciativa. 
Quadro 30- Síntese sobre a visão das subsidiárias da multinacional brasileira

\begin{tabular}{|c|c|}
\hline Dimensões & Principais características \\
\hline $\begin{array}{l}\text { Transferência de } \\
\text { conhecimento }\end{array}$ & $\begin{array}{l}\text { - viagens e treinamentos dos colaboradores internacionais na matriz brasileira } \\
\text { - reuniões e visitas de brasileiros às unidades } \\
\text { - fluxo de conhecimento preponderante da matriz para subsidiárias } \\
\text { - poucas barreiras existentes no processo e que diminuem com o amadurecimento da } \\
\text { relação entre a matriz e a unidade }\end{array}$ \\
\hline Cultura & $\begin{array}{l}\text { - os colaboradores locais estão satisfeitos com o trabalho conjunto com profissionais } \\
\text { brasileiros } \\
\text { - a comunicação é mais eficiente quando existem brasileiros expatriados } \\
\text { - influência positiva da cultura organizacional da matriz, principalmente por meio dos } \\
\text { processos de comunicação e da gestão participativa } \\
\text { - a matriz busca aprender com as unidades, principalmente em relação aos aspectos } \\
\text { culturais } \\
\text { - as diferenças culturais (brasileiras e locais) contribuem para resultados positivos }\end{array}$ \\
\hline $\begin{array}{c}\text { Iniciativa das } \\
\text { unidades }\end{array}$ & $\begin{array}{l}\text { - as unidades buscam identificar oportunidades de negócios, por meio da proximidade } \\
\text { com o mercado local } \\
\text { - parcerias entre as unidades para atender clientes globais } \\
\text { - alta interação das subsidiárias com as redes locais } \\
\text { - a transferência de conhecimento entre as unidades e a matriz facilita a iniciativa } \\
\text { - a matriz valoriza as iniciativas das unidades internacionais }\end{array}$ \\
\hline
\end{tabular}

\section{5 - Análise comparativa dos resultados da WEG}

Nesta seção, a partir das visões e percepções da matriz brasileira e das filiais estrangeiras da Weg, realizou-se uma apreciação dos dados que permitissem explicar o modelo de pesquisa, bem como atendessem ao objetivo deste estudo: analisar a influência da transferência de conhecimento e de fatores culturais na iniciativa das subsidiárias de multinacionais brasileiras.

Inicialmente, sobre o processo de internacionalização da Weg, três fases distintas e seqüenciais ocorreram. Iniciou suas atividades no exterior por meio da exportação de produtos fabricados no Brasil e revendidos pelos distribuidores locais; posteriormente, filiais próprias foram criadas buscando maior controle e possibilidade de diversificação no atendimento ao mercado local, vislumbrando crescimento contínuo e acelerado. Num terceiro momento, a Weg buscou implantar o seu processo produtivo no exterior por meio de aquisição e de construção de plantas, facilitando e otimizando o atendimento do mercado global. 
Desta maneira, assim como outras multinacionais brasileiras, a Weg se internacionalizou e continua sua expansão pelo mundo como estratégia de crescimento, sendo o potencial do mercado local o principal critério na escolha do país, sede das filiais.

A cultura organizacional da Weg está sedimentada na sua história e nos seus fundadores, principalmente no contexto da matriz brasileira, de caráter informal, perceptível nas vestimentas informais dos colaboradores. Outro aspecto a ser destacado é a valorização de todos os profissionais, independente da área de atuação e idade, sendo incentivado o aprendizado entre os indivíduos mais maduros e os mais jovens.

Para as subsidiárias da Weg, a cultura organizacional da matriz influencia positivamente a gestão das unidades, principalmente por meio dos processos de comunicação e da gestão participativa em todos os níveis hierárquicos. Outro ponto destacado é que a matriz brasileira está disposta a aprender com as unidades e reconhece as particularidades e a cultura local, tornando os processos mais flexíveis.

Desta maneira, as diferenças entre as culturas locais e a brasileira contribuem para a obtenção de resultados positivos no contexto da multinacional como um todo. Na área comercial das unidades, os aspectos culturais se tornam mais relevantes, valorizando a atuação dos colaboradores nativos do país, pelo fato destes compreenderem mais facilmente as questões envolvidas em um processo de negociação.

A presença de brasileiros nas unidades é natural e valorizada pelos colaboradores locais, que demonstram satisfação no trabalho conjunto com os profissionais oriundos da matriz, o que denota e confirma que os brasileiros, na maioria, são profissionais com facilidade de relacionamento e adaptação em ambientes diferentes.

Considerando que a cultura organizacional reflete características do país, é importante destacar que apesar da Weg apresentar particularidades da cultura brasileira, há fortes indícios da cultura alemã na sua gestão. Isto porque, a matriz está localizada no norte do estado de Santa Catarina, cuja região foi colonizada predominantemente por imigrantes alemães no início do século XX, sendo $35 \%$ da sua população de ascendência alemã, a maior porcentagem dentre os estados brasileiros. Além da semelhança nos traços físicos, o convívio com a cultura alemã se faz por meio das festas populares, danças e gastronomia. 
Os fundadores da Weg, criados nesse contexto com fortes traços germânicos e ao instituírem a organização em 1961, incutiram valores, crenças e normas, perceptíveis nas políticas e práticas gerenciais. A visão de negócio dos fundadores se diferenciava da visão dos brasileiros naquela época, que pensava apenas no mercado local, visto que a exportação como forma internacionalização se fazia presente como estratégia de negócio na década de 80 , fomentada pela vontade de crescimento e desenvolvimento dos mesmos.

É interessante destacar, que essa característica pode ser observada em outras empresas brasileiras internacionalizadas da região sul do país, como a Marcopolo e a Embraco, contribuindo para a análise de que há influência da cultura regional, no caso alemã, no direcionamento e gestão também destas empresas.

Esses indícios sobre a cultura da Weg e demais organizações das proximidades corroboram com os estudos apontados por Hofstede et al (2010) que evidenciaram a existência de diferenças culturais entre as regiões do Brasil, visto a grande extensão geográfica do país, indicando que a região sul do país apresenta características européia, hierarquia, informalidade, individualista e masculino.

Sobre essas características, somente o individualismo não foi possível de ser identificado nos dados coletados na Weg. A hierarquia e a masculinidade, no entanto, presentes pela busca incessante dos objetivos, foram aspectos destacados no processo de coleta de dados tanto com os representantes da matriz quanto com os diretores das subsidiárias. A informalidade é muito evidente na cultura organizacional da matriz, desde a forma de vestir dos colaboradores até as estratégias de compartilhamento de conhecimentos e práticas com as unidades. Cabe salientar que as subsidiárias também identificam este aspecto menos formal, mas atribuem tal característica à cultura brasileira de forma geral.

Para além do contexto cultural, pelo fato de a Weg ser uma empresa brasileira, localizada em um país emergente, muitas vezes não é bem recebida/vista pelas sociedades mais desenvolvidas, como as européias. Percebe-se uma dificuldade das multinacionais brasileiras nos países europeus, muitas vezes, não pela diferença no nível de desenvolvimento econômico entre as nações, mas pela herança histórica. Por ser o berço da civilização ocidental e ter sido o palco da Revolução Industrial, a Europa e os seus países demonstram um ar de superioridade. 
Dentre as unidades respondentes, parece haver certa resistência da unidade da Itália em relação a gestão brasileira. No estudo realizado por Silva et al (2009) sobre o processo de internacionalização da Embraco, foi constatado que os expatriados brasileiros para a fábrica na Itália, no início do processo, tiveram dificuldades de relacionamento e de trabalho em equipe com os trabalhadores locais, decorrente do patriotismo italiano em detrimento à cultura da matriz brasileira.

Em relação à transferência de conhecimento entre as unidades da Weg, observa-se que existe uma preferência pelos encontros presenciais, que propiciem a socialização (NONAKA e TAKEUCHI, 1997) de conhecimentos tácitos. Estes caracterizam-se como um processo mais informal, privilegiando o fluxo de pessoas entre a matriz e as subsidiárias, em ambos os sentidos.

A promoção dos contatos físicos (pessoal) pela Weg pode ser explicado pela característica cultural brasileira e demais sociedades coletivistas, nas quais Bhagat et al. (2002) identificaram que os indivíduos tendem a considerar o contexto da informação e não se vinculam a questões formais, privilegiando contatos mais informais.

A presença de expatriados brasileiros parece ser muito valorizada nas filiais da multinacional. Por um lado, a matriz brasileira acredita que esta seja uma das maneiras de conseguir transferir a filosofia e cultura da Weg para as unidades, além destes indivíduos dominarem os processos no Brasil, facilitando a implementação e o controle dos mesmos nos locais. Por outro lado, as unidades reconhecem a presença dos expatriados como uma vantagem, no sentido destes compreenderem profundamente os processos organizacionais, além da otimização na comunicação com a matriz, visto a facilidade do idioma e aspectos culturais.

Desta maneira, o objetivo da expatriação na Weg é o de preencher a falta de habilidades críticas, transferindo para a subsidiária internacional o conhecimento e as técnicas das operações; além das habilidades gerenciais dominadas pelo expatriado, de modo a obter maior coordenação e controle, por parte da matriz, assegurando que a subsidiária tenha desempenho compatível com as expectativas e consistência com a estratégia da empresa (VANCE e PAIK, 2006).

Outra forma de transferência de conhecimento promovida pela Weg é o fluxo de colaboradores das filiais para a matriz brasileira para treinamentos pontuais ou visitas técnicas. O objetivo destas práticas de socialização é permitir ao indivíduo tanto o contato 
com o conhecimento técnico quanto com a cultura local e organizacional, difíceis de serem compartilhados à distância.

Como mecanismo de externalização do conhecimento (NONAKA e TAKEUCHI, 1997), da transferência de conhecimento tácito em conhecimento explícito, a Weg proporciona as reuniões anuais com todas as unidades presentes, quando o principal objetivo é o aprendizado conjunto, por meio de benchmarking.

As dificuldades na transferência de conhecimento existem, mas são mais frequentes nas unidades novas, o que de certa forma justifica a presença de um expatriado brasileiro, o que facilita o processo. Outro ponto é que a algumas unidades percebem que o know-how está concentrado na matriz brasileira, decorrente da origem da organização, fazendo com que o conhecimento flua mais desta para as unidades, as quais não se sentem capazes de contribuir com o processo.

Cabe salientar que essa situação não é exclusiva das subsidiárias da Weg, mas uma característica da maioria das multinacionais brasileiras, como constatado na primeira etapa do estudo, ou seja, as unidades estrangeiras são receptoras de conhecimentos, seguindo as orientações da matriz.

Como a maioria das filiais da Weg é fruto de processos de aquisição, a transferência de conhecimento da matriz para a subsidiária é mais intensa do que nos processos de greenfield, possibilitando a criação de valor do novo negócio (BRESMAN, 2009). No entanto, a Weg deve incentivar e valorizar o compartilhamento originado nas filiais adquiridas, pois segundo Bjorkman (2004), estas possuem conhecimentos mais estratégicos para o contexto organizacional, visto que conhecem o contexto local.

Entretanto, a questão cultural pode justificar a predominância no sentido do fluxo de conhecimento, da matriz para a subsidiária. O alto índice de distância do poder do Brasil, estabelecido por Hofstede (2001), indica sociedades e organizações verticais, em que as decisões e as informações seguem a hierarquia top-down (cima para baixo).

Sobre a identificação de oportunidades de negócios, observa-se que nas filiais da Weg as iniciativas internas são mais evidentes e presentes do que as externas, apesar do alto relacionamento das subsidiárias com as redes locais. Visto que a estratégia atual da multinacional brasileira de crescimento acelerado no mercado internacional, as unidades são 
incentivadas a otimizar os seus recursos, divulgando os produtos da Weg e atendendo necessidades customizadas de clientes locais.

Assim, as filiais internacionais da Weg podem ser classificadas como Subsidiárias de Reconfiguração, conforme tipologia desenvolvida por Birkinshaw (1995), sendo que as unidades apresentam aspectos culturais semelhantes à cultura organizacional da multinacional e, a transferência de conhecimento é intensa, principalmente a partir da matriz. Este processo dinâmico de conversão do conhecimento faz com que a subsidiária compreenda cada vez mais o negócio da multinacional e, por isso, possa vislumbrar oportunidades para otimização dos recursos, caracterizando-se como iniciativa interna.

Pelas respostas obtidas, as filiais da Weg demonstram possuir autonomia e presença local, ou seja, no contexto da unidade representam e respondem em nome da multinacional brasileira. No entanto, observa-se uma preocupação por parte das filiais em compartilhar todas as oportunidades com a matriz brasileira, principalmente com o centro de engenharia, ajustandose estrategicamente à multinacional.

Neste sentido, tanto a matriz como as filiais da Weg reconhecem que a transferência de conhecimento mútuo é fundamental para a iniciativa da subsidiária, pois quanto mais a unidade conhecer sobre o negócio da multinacional, mais fácil será a identificação de oportunidades para ampliar a atuação desta e, melhorias nos processos.

$\mathrm{Na}$ medida em que a Weg incentiva as redes de contato local, as unidades passam a ter um alto grau de dinamismo no mercado local, o qual promove a iniciativa da subsidiária (BIRKINSHAW, 1999). Com isso, o ambiente interno da unidade passa a ser permeado pela criatividade e espírito empreendedor, observa-se que o contexto local influencia com maior ênfase às iniciativas da unidade, pela demanda e exigência dos seus clientes e alta competitividade dos concorrentes.

Por meio da pesquisa foi possível constatar que a cultura organizacional da Weg, com o incentivo à gestão participativa e comunicação aberta entre as unidades, parece ser mais preponderante do que a cultura dos próprios países das unidades, facilitando e promovendo um ambiente propício às iniciativas internas e externas.

A iniciativa e a credibilidade da subsidiária estão interligadas e são cíclicas. A credibilidade indica em que medida os gestores da matriz estão conscientes e confiantes na capacidade da 
subsidiária. Assim, o reconhecimento, por parte da matriz brasileira, das oportunidades identificadas pelas unidades, faz com que haja um fortalecimento da credibilidade destas, reiniciando o ciclo das iniciativas. E, corroborando com a proposição de Birkinshaw (1999), ao ressaltar que a credibilidade da subsidiária com a matriz é fundamental para novos processos de iniciativa, assim como o alto nível de comunicação entre as unidades.

Logo, esta etapa qualitativa, permitiu verificar a aplicação do modelo de pesquisa, ou seja, a transferência de conhecimento e a cultura influenciam a iniciativa das subsidiárias da Weg. No entanto, os resultados obtidos nesta fase da pesquisa não podem ser generalizados para as demais multinacionais brasileiras. 


\section{7- DISCUSSÃO DOS RESULTADOS QUANTITATIVOS E QUALITATIVOS}

Como mencionado anteriormente, a abordagem utilizada nesta pesquisa foi de métodos mistos, com a estratégia sequencial explanatória, com a incessante busca do objetivo geral do estudo: analisar a influência da transferência de conhecimento e de fatores culturais na iniciativa das subsidiárias de multinacionais brasileiras.

Para tanto, nos capítulos anteriores, discorreu-se sobre as evidências e análise das duas etapas separadamente: a primeira caracterizada pela abordagem quantitativa, cuja análise se debruçou em uma amostra de 66 subsidiárias de multinacionais brasileiras; enquanto a segunda pela qualitativa, na qual a realidade de uma única empresa foi explorada, a Weg.

Assim, neste capítulo, apresenta-se uma análise conjunta das duas etapas de realização do estudo, ressaltando-se os principais resultados alcançados na pesquisa, cujas explanações são conduzidas pelos objetivos específicos e as sínteses apresentadas em quadros.

\section{1 - O processo de transferência de conhecimento entre a subsidiária e a matriz}

O intuito do objetivo específico de explorar o processo de transferência de conhecimento entre a subsidiária e a matriz era identificar os mecanismos utilizados pela multinacional brasileira, além do mapeamento das barreiras existentes neste processo.

$\mathrm{Na}$ etapa quantitativa, por meio da análise descritiva, pôde-se comparar como tal processo ocorre nas subsidiárias adquiridas versus greenfield. O uso de mecanismos de transferência de conhecimento nas multinacionais brasileiras é predominante, no sentido da matriz para subsidiária, principalmente com as unidades oriundas de processos de aquisição. No sentido oposto, as práticas são mais evidentes nas unidades greenfield.

Esse fato é decorrente da centralização do poder da matriz, característico da cultura brasileira e expresso pelo alto valor na dimensão de distância do poder, conforme discutido por Bhagat et al (2007). 
Outro aspecto importante diz respeito ao tipo de conhecimento e a forma adotada pelas multinacionais brasileiras. Percebe-se que se prioriza o compartilhamento do conhecimento tácito por meio do processo de socialização (NONAKA; TAKEUCHI, 1997), principalmente pelo fluxo intenso de pessoas entre unidades. Também, pelo fato de o Brasil ser um país coletivista (BHAGAT et al, 2007), existe uma tendência para que os processos, contatos e relacionamentos sejam mais informais.

Diante disso, os principais mecanismos de transferência de conhecimento são: reuniões com executivos brasileiros, viagens de colaboradores das unidades estrangeiras para a matriz e a expatriação de brasileiros. No caso das unidades adquiridas, a utilização de manuais de orientação para implantação de processos é reconhecida como prática de transferência de conhecimento da matriz para a subsidiária, enquanto nas unidades greenfield, a realização de treinamentos na matriz torna-se prioridade. Nos dois casos, apesar de serem estratégias distintas, percebe-se que o objetivo final da matriz é o mesmo, o de incutir suas políticas, diretrizes e estilo de gestão nas unidades estrangeiras.

Em relação às barreiras a transferência de conhecimento, observa-se nas multinacionais brasileiras a resistência cultural presente, tanto nos fluxos da matriz para a subsidiária, quanto no sentido contrário. Complementarmente, no caso das unidades adquiridas, a estrutura hierárquica é vista como uma barreira no processo da matriz para a unidade, provavelmente refletindo uma postura centralizadora da primeira; enquanto nas unidades greenfield, a falta de incentivos para o compartilhamento de conhecimento é evidenciado.

Nos fluxos de conhecimentos da subsidiária para a matriz, a síndrome do "não inventado" aqui é uma barreira percebida pelas unidades adquiridas, demonstrando que as multinacionais brasileiras, de maneira geral, criam um obstáculo em relação às ideias oriundas do estrangeiro.

$\mathrm{Na}$ etapa qualitativa, no contexto da multinacional nacional Weg, cujo propósito foi evidenciar resultados que pudessem ilustrar, explicar e auxiliar as interpretações das descobertas, observou-se alguns pontos em relação à transferência de conhecimento entre as unidades.

O sentido principal do fluxo de conhecimento é da matriz brasileira para as unidades e os mecanismos são mais informais e priorizam o contato pessoal, por meio de viagens e treinamentos no Brasil, reuniões e visitas de brasileiros às subsidiárias. Existe uma reunião 
geral anual para compartilhamento de melhores práticas entre todas as unidades. As barreiras são quase inexistentes e reduzem com o fortalecimento da relação entre a matriz brasileira e suas unidades.

Observa-se que a cultura organizacional da matriz é muito importante para a contribuição positiva do processo de transferência de conhecimento, pelo fato de incentivar os contatos entre todos os colaboradores das diversas unidades e a promoção da gestão participativa.

Desta maneira, em relação ao primeiro objetivo, as duas abordagens foram complementares na medida em que o estudo na Weg permitiu ilustrar detalhadamente o processo de transferência de conhecimento nas multinacionais brasileiras, conforme o Quadro 31. 


\section{Quadro 31- Processo de transferência de conhecimento entre a subsidiária e a matriz}

\begin{tabular}{|c|c|c|}
\hline \multirow{7}{*}{$\begin{array}{l}\text { Resultados Esperados e } \\
\text { Confirmados com a } \\
\text { Literatura }\end{array}$} & Evidência & Explicaçãáo \\
\hline & $\begin{array}{l}\text { - fluxo de conhecimento predominante no sentido da matriz para } \\
\text { subsidiária }\end{array}$ & $\begin{array}{l}\text { - Corrobora com Bhagat et al (2002) fluxo de informações nas culturas verticais (alta } \\
\text { distância do poder) geralmente ocorre de cima para baixo } \\
\text { - Ocorrência normal diante do fato de serem multinacionais brasileiras em início do processo } \\
\text { de internacionalização }\end{array}$ \\
\hline & $\begin{array}{l}\text { - fluxo de conhecimento da matriz para subsidiária preponderante } \\
\text { nas unidades adquiridas }\end{array}$ & $\begin{array}{l}\text { - Corrobora com Bresman }(1999,2010) \text { e Meyer et al (2009) - fundamental para criação de } \\
\text { valor do negócio e aprendizado da multinacional } \\
\text { - Unidades geralmente novas exigem maior contato para estabelecer relações de confiança }\end{array}$ \\
\hline & $\begin{array}{l}\text { - socialização de conhecimento tácito por meio do fluxo intenso de } \\
\text { pessoas e processos mais informais }\end{array}$ & \multirow{2}{*}{$\begin{array}{l}\text { Corrobora com Bhagat et al (2002) - culturas coletivistas, como o Brasil, utilizam meios mais } \\
\text { informais e contatos pessoais ou telefônicos e absorvem mais conhecimento tácito }\end{array}$} \\
\hline & $\begin{array}{l}\text { - principais mecanismos utilizados: reuniões com executivos } \\
\text { brasileiros, viagens para matriz e expatriação de brasileiros }\end{array}$ & \\
\hline & $\begin{array}{l}\text { - resistência cultural é a principal barreira no processo de } \\
\text { transferência de conhecimento em ambos os sentidos; }\end{array}$ & $\begin{array}{l}\text { Corrobora com Takeuchi e Nonaka (2008) e Bhagat et al (2002) - transferência de } \\
\text { conhecimento é mais efetiva quando envolve contexto cultural similar; }\end{array}$ \\
\hline & $\begin{array}{l}\text { - síndrome do "não inventado aqui" é percebida pelas unidades } \\
\text { adquiridas; }\end{array}$ & $\begin{array}{l}\text { Corrobora com Gupta e Govindarajam (2000) - barreira em aceitar ideias e conhecimentos } \\
\text { gerados nas unidades }\end{array}$ \\
\hline \multirow{6}{*}{$\begin{array}{l}\text { Resultados e } \\
\text { Contribuições da } \\
\text { pesquisa }\end{array}$} & Evidência & Interpretação \\
\hline & $\begin{array}{l}\text { - unidades adquiridas: baixo uso dos mecanismos de transferência } \\
\text { de conhecimento da subsidiária para matriz }\end{array}$ & $\begin{array}{l}\text { - Centralização do poder e síndrome do "não inventado aqui" por parte da matriz brasileira } \\
\text { - Multinacional brasileira pode estar perdendo conhecimentos relevantes do contexto local }\end{array}$ \\
\hline & $\begin{array}{l}\text { - unidades greenfield: os resultados evidenciaram que estas } \\
\text { utilizam mais os mecanismos de transferência de conhecimento da } \\
\text { subsidiária para matriz }\end{array}$ & $\begin{array}{l}\text { - Diferente da literatura - Gupta e Govindarajan (2000) apontam que a disseminação do } \\
\text { conhecimento é mais evidente em unidades adquiridas } \\
\text { - essas unidades apresentam alta capacidade de absorção }\end{array}$ \\
\hline & $\begin{array}{l}\text { - as barreiras a transferência de conhecimento nas unidades } \\
\text { adquiridas são mais presente em ambos os sentidos do que nas } \\
\text { greenfield }\end{array}$ & $\begin{array}{l}\text { - resistência cultural de ambas as partes, tanto da matriz quanto da subsidiária, demonstrando } \\
\text { falta de valorização do conhecimento do outro e resistência ao diferente }\end{array}$ \\
\hline & $\begin{array}{l}\text { - unidades greenfield sentem falta de incentivos para } \\
\text { compartilhamento de conhecimentos }\end{array}$ & $\begin{array}{l}\text { - Demonstra de certa forma que o conhecimento da subsidiária não é relevante ou valorizado } \\
\text { para o negócio } \\
\text { Contraditório à literatura - Gupta e Govindarajan (2000) defendem que deve existir um } \\
\text { sistema de recompensas }\end{array}$ \\
\hline & $\begin{array}{l}\text { - cultura organizacional da matriz favorece e incentiva o } \\
\text { compartilhamento de conhecimento }\end{array}$ & $\begin{array}{l}\text { - Quanto mais semelhante a cultura da subsidiária à matriz, mais fácil é a transferência de } \\
\text { conhecimento } \\
\text { - Necessário a utilização de técnicas que promovam o compartilhamento do conhecimento }\end{array}$ \\
\hline
\end{tabular}




\section{2 - Características da cultura da subsidiária}

Buscou-se como objetivo específico identificar características da cultura da subsidiária, evidenciar aspectos culturais da subsidiária e verificar se existem diferenças destes em relação ao Brasil ou mesmo se nuances da cultura brasileira são percebidas nas unidades.

A etapa quantitativa permitiu identificar que algumas características culturais brasileiras estão presentes nas subsidiárias de multinacionais brasileiras, principalmente as relacionadas à questão do poder, centralização e hierarquia, expressas pelos altos índices nas dimensões de distância do poder e controle de incerteza na sociedade brasileira, conforme estudo do Hofstede (2005).

Pelos resultados analisados, tanto a dimensão do individualismo quanto a da masculinidade não apresentaram impactos evidentes nas subsidiárias brasileiras. Em relação à masculinidade, pelo fato desta dimensão ser neutra para a sociedade brasileira, não há relevância para o modelo de gestão brasileiro tanto no contexto nacional quanto no internacional, na dinâmica das subsidiárias. No entanto, apesar de o coletivismo ser considerado uma característica positiva do Brasil, tornando os brasileiros pessoas abertas, que proporcionam o relacionamento interpessoal, e um ambiente de trabalho informal, não houve evidências destes aspectos nas subsidiárias, considerando a amostra estudada.

Foi possível constatar que a cultura do Brasil influencia a gestão das subsidiárias via cultura organizacional da matriz (ou da multinacional como um todo), visto que as unidades estrangeiras, de certa maneira, possuem aspectos da cultura do país de origem da empresa.

Essa constatação foi reafirmada com a etapa qualitativa, com o estudo na Weg. Nesta empresa, percebe-se uma influência positiva da cultura organizacional da matriz nas unidades estrangeiras, principalmente devido à contínua interação nos processos de comunicação e a promoção da valorização e gestão participativa de todos os colaboradores, em todos os níveis organizacionais.

Outras características organizacionais da Weg, valorizadas pelas unidades estrangeiras, são: respeito à cultura local e às particularidades de cada subsidiária, tornando os processos 
organizacionais mais flexíveis, a presença de expatriados brasileiros e a abertura ao aprendizado da matriz com as unidades.

Assim, apesar de cada organização ter sua própria cultura, com normas e valores particulares, a cultura nacional é um fator muito relevante e de grande influência na cultura organizacional. De forma que tornar-se relevante salientar também que os resultados deste estudo em relação à cultura indicam tendência à perspectiva divergente desta no contexto mundial, ou seja, que não há uma predominância dos modelos de gestão dos países desenvolvidos e que estes seriam utilizados como padrões para os demais países do mundo.

O Quadro 32 elenca os resultados esperados e confirmados pela literatura, bem como as contribuições da pesquisa. 


\section{Quadro 32 - Característica da cultura da subsidiária}

\begin{tabular}{|c|c|c|}
\hline \multirow{4}{*}{$\begin{array}{l}\text { Resultados Esperados e } \\
\text { Confirmados com a } \\
\text { Literatura }\end{array}$} & Evidência & Explicação \\
\hline & $\begin{array}{l}\text { - percepção de alta distancia do poder e estrutura hierárquica } \\
\text { tradicional nas subsidiárias, mesmo nas unidades localizadas em } \\
\text { países com baixo valor para esta dimensão }\end{array}$ & $\begin{array}{l}\text { - tendência dos aspectos da cultura organizacional da multinacional brasileira serem mais } \\
\text { impactantes que a própria cultura nacional do país onde a subsidiária está alocada } \\
\text { - Corrobora com os dados do Hofstede (2005) referentes ao Brasil para as dimensões de } \\
\text { distancia do poder e controle de incerteza } \\
\text { - Corrobora com os estudos sobre a existência da visão divergente da cultura, ou seja, que não } \\
\text { existe um modelo preponderante de gestão no âmbito internacional }\end{array}$ \\
\hline & $\begin{array}{l}\text { - há influência da cultura nacional do país no modelo de gestão das } \\
\text { organizações }\end{array}$ & $\begin{array}{l}\text { - Corrobora com os estudos de cultura sobre o impacto da cultura nacional na organizacional e } \\
\text { modelos de gestão. Desta maneira, as empresas multinacionais brasileiras, ao decidirem o país } \\
\text { sede da subsidiária, devem examinar a cultura local, elencando aspectos similares e diferentes } \\
\text { da cultura de origem, buscando minimizar os conflitos entre as partes }\end{array}$ \\
\hline & $\begin{array}{l}\text { - as diferenças culturais influenciam positivamente na atuação das } \\
\text { unidades estrangeiras }\end{array}$ & $\begin{array}{l}\text { - Corrobora com Moran et al (1996) que evidencia ganhos e vantagem competitiva para as } \\
\text { empresas globais quando estas são capazes de combinar diferentes traços culturais }\end{array}$ \\
\hline \multirow{3}{*}{$\begin{array}{c}\text { Resultados e } \\
\text { Contribuições da } \\
\text { pesquisa }\end{array}$} & Evidência & Interpretação \\
\hline & $\begin{array}{l}\text { - cultura organizacional da matriz parece influenciar o modelo de } \\
\text { gestão das subsidiárias } \\
\text { - no caso da Weg, os aspectos culturais tais como a gestão } \\
\text { participativa e a intensa comunicação entre a matriz e a subsidiária } \\
\text { são características relevantes para a iniciativa da unidade; além de } \\
\text { características culturais regionais do sul do país }\end{array}$ & $\begin{array}{l}\text { - a presença de características da cultura nacional brasileira nas subsidiárias pode ser } \\
\text { decorrente das próprias culturas organizacionais das matrizes visto que, estas de certa } \\
\text { maneira, apresentam aspectos da cultural do país de origem da empresa }\end{array}$ \\
\hline & $\begin{array}{l}\text { - o coletivismo e a masculinidade não se apresentam tão evidentes } \\
\text { nos aspectos da cultura da subsidiária na etapa quantitativa } \\
\text { - na Weg, o direcionamento para resultados (masculinidade) é } \\
\text { evidente e o coletivismo também visto que as relações interpessoais } \\
\text { próximas }\end{array}$ & $\begin{array}{l}\text { - No caso da masculinidade, devido os países da amostra não apresentar valores expressivos } \\
\text { para esta dimensão e mesmo pelo fato do Brasil apresentar baixo valor, não foi relevante nas } \\
\text { subsidiárias. No entanto, em casos particulares, pode existir influência. Uma explicação para } \\
\text { isso são as diferenças culturais entre as regiões do Brasil, sendo o sul mais masculino } \\
\text { (HOFSTEDE et al, 2010) } \\
\text { - O fato de o Brasil ser um país coletivista pode facilitar o processo de adaptação e integração } \\
\text { das unidades, visto que os brasileiros convivem com a diversidade cultural do próprio país e } \\
\text { são flexíveis }\end{array}$ \\
\hline
\end{tabular}




\section{3- A influência da cultura e da transferência de conhecimento na iniciativa da subsidiaria}

O propósito do objetivo específico de analisar a influência da cultura e da transferência de conhecimento na iniciativa da subsidiária foi o de identificar se a transferência de conhecimento e a cultura influenciam direta e positivamente à iniciativa da subsidiária; bem como se existe relação direta e positiva entre a cultura e a transferência de conhecimento.

Na primeira etapa, quantitativa, foi possível validar o modelo de pesquisa proposto, visto que este explicou $28,9 \%$ da variabilidade da iniciativa da subsidiária de multinacional brasileira, considerado um resultado satisfatório nos estudos de ciências sociais.

Como o modelo deste estudo relaciona dimensões predominantemente comportamentais como a cultura e a transferência de conhecimento, os $71,1 \%$ da iniciativa da subsidiária podem estar relacionados a outras variáveis estruturais, tanto no âmbito local da unidade quanto no contexto corporativo; como a centralização da decisão e a credibilidade da subsidiária, evidenciadas nas análises dos resultados da técnica estatística.

Além das variáveis comportamentais e estruturais não presentes no modelo deste estudo, outros fatores ambientais e organizacionais que podem promover a iniciativa das subsidiárias devem ser considerados. Em relação aos fatores ambientais locais, destacam-se questões administrativas (política e educacional) e econômicas do país sede da subsidiária que podem influenciar positiva ou negativamente à iniciativa da mesma.

Ainda sobre a etapa quantitativa, foi possível verificar as três hipóteses do modelo proposto do estudo, sendo que duas foram confirmadas. A iniciativa da subsidiária é diretamente influenciada pela transferência de conhecimento e este, por sua vez, influenciado pela cultura. Entretanto, a influência da cultura na iniciativa da subsidiária não foi possível confirmar com a amostra do estudo.

A transferência do conhecimento influencia em $25,3 \%$ a iniciativa da subsidiária, mostrando que quanto maior o domínio de conhecimento da unidade, melhor a possibilidade de identificar oportunidades de negócios no contexto local no da corporação. 
Os resultados evidenciaram que a cultura influencia diretamente a transferência de conhecimento nas subsidiárias de multinacionais brasileiras em todos os sentidos, corroborando com as preposições de Bhagat et al (2002) e Takeuchi e Nonaka (2008) sobre a importância da compreensão do contexto, principalmente cultural, para um eficiente processo de transferência de conhecimento.

Mesmo não sendo confirmada a hipótese de que a cultura influencia diretamente a iniciativa das subsidiárias brasileiras, houve indícios da sua importância. Pelo fato de ser indispensável para o processo de transferência de conhecimento eficiente e eficaz e, sendo este diretamente impactante na iniciativa da subsidiária, a compreensão da cultura é relevante e imprescindível para atuação e crescimento no contexto internacional.

O estudo sobre a Weg, na segunda fase da pesquisa, permitiu ilustrar o modelo proposto, bem como as relações entre os construtos: transferência de conhecimento, cultura e iniciativa. Foi possível averiguar que a transferência de conhecimento, por meio, principalmente, da socialização informal, e a cultura organizacional da multinacional favorecem a iniciativa das unidades internacionais.

Salienta-se que os resultados da pesquisa (Quadro 33) indicaram que, além dos construtos propostos no modelo, outras variáveis estruturais como o nível de desenvolvimento do país sede da subsidiária e a credibilidade desta diante da matriz, influenciam na identificação de oportunidades de negócios no local e corporativo. 
Quadro 33 - Influência da cultura e da transferência de conhecimento na iniciativa da subsidiaria

\begin{tabular}{|c|c|c|}
\hline \multirow{3}{*}{$\begin{array}{l}\text { Resultados Esperados e } \\
\text { Confirmados com a } \\
\quad \text { Literatura }\end{array}$} & Evidência & Explicação \\
\hline & $\begin{array}{l}\text { - A iniciativa da subsidiária é diretamente influenciada pela } \\
\text { transferência de conhecimento (H1) }\end{array}$ & $\begin{array}{l}\text { - Corrobora com Birkinshaw (1999) e Nohria e Ghosal (1994), sobre a relevância do } \\
\text { conhecimento para o desenvolvimento da subsidiária; } \\
\text { - Quanto mais dinâmico o processo de disseminação do conhecimento (Gupta e Govindarajan, } \\
\text { 1991), maior a aprendizagem organizacional (Garvin, 2000) }\end{array}$ \\
\hline & $\begin{array}{l}\text { - A transferência de conhecimento é diretamente influenciada pela } \\
\text { cultura (H3) }\end{array}$ & $\begin{array}{l}\text { - Corrobora com Bhagat et al (2002) e Takeuchi e Nonaka (2008) sobre a importância da } \\
\text { compreensão do contexto, principalmente cultural, para um eficiente processo de transferência } \\
\text { de conhecimento }\end{array}$ \\
\hline \multirow{6}{*}{$\begin{array}{l}\text { Resultados e } \\
\text { Contribuições da } \\
\text { pesquisa }\end{array}$} & Evidência & Interpretação \\
\hline & - Validação do modelo de pesquisa & $\begin{array}{l}\text { - Apesar da existência de outros fatores que influenciam a iniciativa das subsidiárias } \\
\text { brasileiras, a transferência de conhecimento e a cultura se fazem presentes, mesmo que } \\
\text { indiretamente. }\end{array}$ \\
\hline & $\begin{array}{l}\text { - A iniciativa da subsidiária não é diretamente influenciada pela } \\
\text { cultura (H2), mais é relevante no processo de iniciativa como } \\
\text { aspecto complementar ao contexto organizacional da unidade } \\
\text { internacional }\end{array}$ & $\begin{array}{l}\text { - Pelo fato de ser indispensável para o processo de transferência de conhecimento eficiente e } \\
\text { eficaz e sendo este diretamente impactante na iniciativa da subsidiária, a compreensão da } \\
\text { cultura é relevante e imprescindível para atuação e crescimento no contexto internacional. } \\
\text { - A não confirmação da hipótese pode estar relacionada com a abstração do construto cultura } \\
\text { e a subjetividade do respondente do instrumento de coleta de dados, pelo fato de apenas um } \\
\text { indivíduo de cada subsidiária ter participado da pesquisa; talvez com uma representatividade } \\
\text { maior, os resultados pudessem ser diferentes, mais favoráveis }\end{array}$ \\
\hline & $\begin{array}{l}\text { - Fatores ambientais e estruturais favorecem também a iniciativa da } \\
\text { subsidiária, como a centralização das decisões e a credibilidade da } \\
\text { subsidiária }\end{array}$ & $\begin{array}{l}\text { - A centralização das decisões influencia o processo de transferência de conhecimento, } \\
\text { afetando negativamente a iniciativa das subsidiárias; } \\
\text { - Quanto maior a credibilidade da subsidiária perante a matriz, provavelmente menor será a } \\
\text { possibilidade da existência da síndrome do "não inventado aqui" }\end{array}$ \\
\hline & $\begin{array}{l}\text { - O nível de desenvolvimento do país sede da subsidiária influencia } \\
\text { na identificação de oportunidades de negócios no local e } \\
\text { corporativo }\end{array}$ & $\begin{array}{l}\text { - O nível de desenvolvimento econômico do país, representando pelo custo e qualidade dos } \\
\text { recursos naturais, financeiros, humanos, infraestrutura e informações (GHEMAWAT, 2008), } \\
\text { pode influenciar positiva ou negativamente à iniciativa da subsidiária, principalmente à } \\
\text { externa }\end{array}$ \\
\hline & Importância da liderança e capacidades distintivas para a iniciativa & $\begin{array}{l}\text { - O papel do gestor na subsidiária é fundamental para a busca de novas oportunidades de } \\
\text { negócios, bem como a capacidade da unidade apreender os novos conhecimentos e aplicá-los } \\
\text { no contexto local de forma a contribuir para o desenvolvimento da multinacional como um } \\
\text { todo. }\end{array}$ \\
\hline
\end{tabular}


7.4 - Configuração de grupos homogêneos de subsidiárias a partir da cultura, transferência de conhecimento e iniciativa

O objetivo específico de identificar se a cultura, a transferência de conhecimento e a iniciativa permitem a configuração de grupos homogêneos de subsidiárias foi atingido, posto que os resultados da modelagem de equações estruturais para das variáveis: cultura, transferência de conhecimento (entre matriz e subsidiária) e, a iniciativa (interna e externa), foram os critérios para o agrupamento das 66 subsidiárias brasileiras da amostra em três conglomerados.

Fundamentado na tipologia desenvolvida por Birkinshaw (1995) para classificar as subsidiárias segundo a iniciativa, os três conglomerados foram classificados em: (1) Iniciativa de reconfiguração e (3) - Iniciativa no mercado local. Visto que as subsidiárias do conglomerado (2) não puderam ser classificadas na tipologia referenciada, foi denominado de Iniciativa incipiente. Também, buscou-se assinalar a predominância em cada grupo dos continentes que sediam as unidades, bem como o setor de atuação das mesmas.

O conglomerado 1, denominado de Iniciativa de reconfiguração, é caracterizado pelas subsidiárias com características culturais semelhantes às do Brasil, e apresentam uma alta interação com a matriz em termos de transferência de conhecimento. Esta dinâmica permite que as unidades internacionais conheçam o negócio da multinacional brasileira a ponto de fomentarem propostas de melhoria nos processos da corporação como um todo. Neste grupo predominam empresas do setor de serviço, tecnologia e montadoras de sistemas, que estão localizadas em países que possuem um alto desenvolvimento em pesquisa e tecnologia, o que promove um aprendizado ainda maior para a matriz brasileira.

Por sua vez, as subsidiárias classificadas como Iniciativa no mercado local, conglomerado 3, apresentam valores altos para a iniciativa externa, buscando oportunidades a partir das redes de contato no seu contexto local. As demais variáveis apresentaram valores médios, indicando a importância da transferência de conhecimento entre as unidades e a proximidade cultural com o Brasil para a atuação local. De alguma forma, este processo pode ser facilitado pela localização dos países das unidades, predominantes na América Latina, e pela característica 
dos insumos básicos como setor de atuação, que necessita de prospecção de clientes constantemente.

Entretanto, devido às características do conglomerado 2, o mesmo não pode ser classificado em relação a tipologia inicial de Birkinshaw (1995), sendo denominado de Iniciativa Incipiente. Este grupo apresenta valores baixos para todas as variáveis com exceção do grau médio para a cultura, cujas subsidiárias estão localizadas principalmente na América Latina e África. Acredita-se que a baixa iniciativa (interna e externa) seja decorrente, fundamentalmente, do campo de atuação, de recursos naturais, onde as demandas de atendimento internacional antecedem o processo de internacionalização da multinacional brasileira.

Originalmente, a etapa qualitativa da pesquisa não contemplava este objetivo. No entanto, a partir da classificação e denominação dos conglomerados das subsidiárias brasileiras em relação à iniciativa (reconfiguração, incipiente e de mercado) e da análise da Weg, foi possível constatar que as subsidiárias da multinacional brasileiras apresentam-se como iniciativa de reconfiguração.

Os principais resultados obtidos em relação a este objetivo estão expostos no Quadro 34. 
Quadro 34- Configuração de grupos homogêneos de subsidiária

\begin{tabular}{|c|c|c|}
\hline \multirow[b]{2}{*}{$\begin{array}{c}\text { Resultados Esperados e } \\
\text { Confirmados com a } \\
\text { Literatura }\end{array}$} & Evidência & Explicação \\
\hline & $\begin{array}{l}\text { - caracterização de conglomerados em relação a iniciativa, } \\
\text { considerando os construtos: transferência de conhecimento da } \\
\text { matriz para subsidiária, desta para matriz, além da cultura }\end{array}$ & $\begin{array}{l}\text { - Birkinshaw (1995) propôs uma tipologia para a iniciativa das subsidiárias que foi } \\
\text { parcialmente verificado neste estudo; somente as iniciativas de reconfiguração e mercado } \\
\text { local foram identificadas }\end{array}$ \\
\hline \multirow{3}{*}{$\begin{array}{l}\text { Resultados e } \\
\text { Contribuições da } \\
\text { pesquisa }\end{array}$} & Evidência & Interpretação \\
\hline & $\begin{array}{l}\text { - identificação de características dos conglomerados em relação a } \\
\text { dinâmica de transferência de conhecimento entre os aspectos } \\
\text { culturais na iniciativa da subsidiária dos conglomerados em } \\
\text { relação ao nível }\end{array}$ & $\begin{array}{l}\text { - Iniciativa de reconfiguração - subsidiárias com características culturais semelhantes ao } \\
\text { Brasil, apresentam uma alta interação com a matriz em termos de transferência de } \\
\text { conhecimento, permitindo que as unidades internacionais conheçam o negócio da } \\
\text { multinacional brasileira a ponto de fomentarem propostas de melhoria nos processos da } \\
\text { corporação como um todo } \\
\text { - Iniciativa no mercado local - unidades apresentam valores altos para a iniciativa externa, } \\
\text { buscando oportunidades a partir das redes de contato no seu contexto local. As demais } \\
\text { variáveis apresentaram valores médios, indicando a importância da transferência de } \\
\text { conhecimento entre as unidades e a proximidade cultural com o Brasil para a atuação local } \\
\text { - Iniciativa Incipiente - unidades com valores baixos para todas as variáveis com exceção da } \\
\text { cultura (médio), consequentemente, uma baixa iniciativa }\end{array}$ \\
\hline & $\begin{array}{l}\text { - caracterização dos conglomerados em relação setor de atuação e } \\
\text { continente em que as subsidiárias estão localizadas }\end{array}$ & $\begin{array}{l}\text { - Iniciativa de reconfiguração- predomínio de empresas do setor de serviço, tecnologia e } \\
\text { montadoras de sistemas, que estão localizadas em países que possuem um alto } \\
\text { desenvolvimento em pesquisa e tecnologia, o que promove um aprendizado ainda maior para } \\
\text { a matriz brasileira } \\
\text { - Iniciativa de Mercado Local - unidades predominantes na América Latina, atuantes no setor } \\
\text { de insumos básicos, que necessitam de prospecção de clientes constantemente } \\
\text { - Iniciativa Incipiente - unidades localizadas na América Latina e África, com atuação no } \\
\text { setor de recursos naturais; com demandas de trabalho previamente definidas }\end{array}$ \\
\hline
\end{tabular}




\section{8 - CONSIDERAÇÕES FINAIS}

O aumento da presença de capital brasileiro no exterior nos anos 2000 tem fomentado os estudos acadêmicos sobre a internacionalização das multinacionais emergentes do país.

Assim como há diversas teorias para explicar o processo de internacionalização, a gestão de multinacionais é um campo de estudo muito abrangente, que possibilita reflexões sobre diversos temas. Dentre as vertentes de pesquisa dos estudos de gestão internacional, a importância das subsidiárias para o negócio das empresas multinacionais tem sido destacada e discutida.

No entanto, visto o estágio inicial de internacionalização das empresas brasileiras, os estudos acadêmicos sobre as subsidiárias são recentes, o que permite explorar novas e complementares vertentes. Diante disto, esta pesquisa surgiu com o propósito de contribuir aos conhecimentos sobre as empresas multinacionais brasileiras, mais particularmente sobre suas subsidiárias.

Assim, este estudo teve como objetivo geral analisar a influência da transferência de conhecimento e de fatores culturais na iniciativa das subsidiárias de multinacionais brasileiras, cujas principais contribuições são apresentadas neste capítulo, bem como suas limitações e sugestões para futuros estudos.

\section{1 - Contribuições do estudo}

Dentre os propósitos de uma pesquisa em ciências sociais aplicada, destaca-se a contribuição em termos teóricos, metodológico e para o contexto empresarial.

Uma das contribuições do estudo foi o enriquecimento da literatura acadêmica em construção sobre as subsidiárias de multinacionais brasileiras, principalmente o olhar acerca da iniciativa das mesmas, bem como a influência da transferência de conhecimento e da cultura na dinâmica organizacional. 
A definição de um modelo teórico com variáveis predominantemente comportamentais e que pôde ser validado com a utilização da técnica estatística de modelagem de equações estruturais também é relevante para os estudos em negócios internacionais, principalmente no contexto brasileiro.

Em termos metodológicos, a utilização de uma estratégia mista de pesquisa, com abordagem quantitativa e qualitativa em dois momentos, demonstrou ser engrandecedora para o estudo em internacionalização, identificando e aprofundando discussões, principalmente no caso brasileiro, visto que se trata de um movimento novo e que as empresas se encontram em um estágio inicial.

Os resultados obtidos na primeira etapa do estudo, quantitativa, foram fundamentais para explorar e descrever aspectos relevantes das subsidiárias, bem como analisar o modelo proposto; enquanto a etapa qualitativa, com o estudo na Weg, permitiu ilustrar e confirmar algumas evidências da fase anterior.

Para o contexto empresarial, a realização da pesquisa permitiu identificar algumas sugestões para a atuação das multinacionais brasileiras no contexto internacional, tais como: erradicar as barreiras existentes e promover mais mecanismos de transferência de conhecimento entre as unidades; valorizar as características culturais da multinacional e do país sede da subsidiária, favorecendo uma aproximação das unidades, principalmente, das adquiridas à realidade da organização brasileira, promovendo assim a iniciativa das subsidiárias.

Outro ponto a ser destacado é que as multinacionais brasileiras devem explorar o potencial de desenvolvimento tecnológico do país sede da subsidiaria, visto que os resultados da pesquisa demonstraram ser esta uma excelente forma de visualizar oportunidades de negócios para a corporação como um todo.

\section{2 - Limitações do estudo}

Como toda pesquisa acadêmica apresenta limitações, este estudo não poderia ser diferente.

Apesar de o tamanho da amostra na etapa quantitativa, constituído por 66 subsidiárias, ter permitido a análise e validação do modelo de pesquisa, tal número é restrito. Caso no modelo 
de pesquisa outros construtos de análise e variáveis fossem incluídas, como as estruturais, seria necessário uma amostra de tamanho maior para viabilizar a análise.

Outro aspecto limitador é o fato de ter sido realizado um estudo transversal, retratando a dinâmica das subsidiárias em um determinado período específico, em cada uma das etapas da pesquisa.

Em relação aos procedimentos metodológicos, na fase quantitativa, o questionário autopreenchido foi respondido por um representante de cada subsidiária da amostra, o que pode ter gerado um viés, visto que o respondente pode ter explicitado, muitas vezes, a sua percepção pessoal sobre a unidade. Quanto às questões relativas à cultura, essa situação tornase mais sensível, visto que este construto apresenta caráter subjetivo.

\section{3 - Sugestões para pesquisas futuras}

A pesquisa científica é entendida como a busca constante de explicações e de soluções, um processo dinâmico e contínuo. Assim, de uma pesquisa como esta, surgem diversas ideias e indagações para futuras.

Visto que este estudo foi de cunho transversal, uma sugestão seria investigar novamente uma amostra de subsidiárias de multinacionais brasileiras, aplicando o modelo proposto de estudo, que permitisse uma análise longitudinal. Também, torna-se interessante a aplicação do modelo em multinacionais de outros países, que permitisse um estudo comparativo com os resultados brasileiros.

Em relação ao modelo de pesquisa proposto, seria relevante inserir outras variáveis, tais como as estruturais e as do contexto sócio econômico do país sede da subsidiária.

Para aprofundar a interpretação dos dados resultantes da etapa quantitativa, sugere-se, portanto, a realização de pesquisas em outras multinacionais brasileiras utilizando a abordagem qualitativa como na segunda fase deste estudo.

Da mesma forma que Ambos et al (2010) pesquisaram as consequências da iniciativa das subsidiárias para as multinacionais em três diferentes países (Austrália, Canadá e Inglaterra), outros poderiam pesquisar tais consequências na realidade brasileira. 


\section{REFERÊNCIAS}

AIDAR, M. M.; BRISOLA, A. B.; MOTTA, F. C. P.; WOOD, T (Org.). Cultura organizacional brasileira. In: Mudança organizacional. 4ed. São Paulo: Atlas, 2004.

AMBOS, T.; ANDERSSON, U.; BIRKINSHAW, J. What are the consequences of initiativetaking in multinational subsidiaries? Journal of International Business Studies, v.41, n.7, 2010.

ANDERSSON, U.; FORSGREN, M.; HOLM, U. The strategic impact of external networks: subsidiary performance and competence development in the multinational corporation. Strategic Management Journal, v.23, 2002.

ANG, Z.; MASSINGHAM, P. National culture and the standardization versus adaptation of knowledge management in Journal of knowledge management, v.11, n.2, 2007.

BABBIE, E. Métodos de pesquisas de survey. Belo Horizonte, Ed. UFMG, 2005.

BARTLETT, C; GHOSHAL, S. Managing across Borders - The Transnational solution. HBS Press, 1999.

BARNEY, J. Firm resources and sustained competitive advantage. Journal of Management, v.17, n.1, p.99-120, 1991.

BHAGAT, R. S.; ENGLIS, P.; KEDIA, B. L. Creation, diffusion, and transfer of organizational knowledge in transnational and global organizations In: Management: International Perspectives, p.101-125, 2007.

BHAGAT, R. S.; HAVERSTON, P. D.; TRIANDIS, H. C. Cultural variations in the crossborder transfer of organizational knowledge: an integrative framework. Academy of Management Review, v.27, n.2, p.21-204, 2002.

BJORKMAN, I; BARNER-RASMUSSEN, W.; LI, L. Managing Knowledge Transfer in MNCs: The Impact of Headquarters Control Mechanisms. Journal of International Business Studies, v.35, p.443-445, 2004.

BIRKINSHAW, J. Entrepreneurship in Multinational Corporations: the Initiative Process in Foreign Subsidiaries. The University Western of Ontario, Faculty of Graduate Studies. London, TESE, March, 1995.

BIRKINSHAW, J. Entrepreneurship in multinational corporations: the characteristics of subsidiary indicatives. Strategic Management Journal, 1997.

BIRKINSHAW, J.; NOBEL, R.; RIDDERSTRALE, J. Knowledge as a contingency variable: do the characteristics of knowledge predict organization structure? Organization Science, may/jun, p.3-13, 2002.

; The Determinants and Consequences of Subsidiary Initiative in Multinational Corporations. Entrepreneurship Theory and Practice. Fall, 1999. 
BIRKINSHAW, Julian and HOOD, Neil. Multinational Corporate Evolution and Subsidiary Development. Macmillan Press Ltd, 1998.

; HOOD, N.; STEFAN, J. Building firm-specific advantages in Multinational Corporations: the role of subsidiary initiative. Strategic Management Journal, March, p.319, 1998.

; MORRISON, A. Configurations of strategy and structure in subsidiaries of multinational corporations. Journal of International Business Studies, fourth quarter, 1995.

; FRY, N. Subsidiary Initiatives to develop new markets. Sloan Management Review, spring, p.3-39, 1998.

BORINI, F. M. Transferência, desenvolvimento e reconhecimento de competências organizacionais em subsidiárias estrangeiras de multinacionais brasileiras. São Paulo, 2008. Tese (Doutorado em Administração). Programa de Pós-Graduação em Administração. Faculdade de Economia, Administração e Contabilidade da Universidade de São Paulo.

As estratégias das subsidiárias brasileiras no exterior IN: FLEURY, A. Gestão empresarial para a internacionalização das empresas brasileiras. São Paulo: Atlas, 2010.

BOURDIEU, P. O Poder Simbólico. Rio de Janeiro: Editora Bertrand Brasil SA. 1989.

BRESMAN, H.; BIRKINSHAW, J.; NOBEL, R. Knowledge transfer in international acquisitions. Journal of International Business Studies, p.3-30, 1999.

Decade Award Winning Article. Knowledge transfer in international acquisitions. Journal of International Business Studies v.41, p.5-20, 2010.

CANCLINI, N. G. Diferente, desiguais e desconectados. Rio de Janeiro: Editora UFRJ, 2005.

CAVEDON, N. Antropologia para administradores. Porto Alegre: Editora da UFRGS, 2008.

CAVUSGIL, S.; KNIGHT, G.; RIESENBERGER, J. Negócios Internacionais: estratégia, gestão e novas realidades. São Paulo: Pearson Prentice Hall, 2010.

CHAI, K.; GREGORY, M.; SHI, Y. Bridging Islands of Knowledge: A Framework of Knowledge Sharing Mechanisms. International Journal of Technology Management. v.25, n.8, p.703-727, 2003.

CHIN, W. Issues and opinion on structural equation modeling. MIS Quarterly; March, p.1$21,1998$.

CYRINO, A.; BARCELLOS, E.; TANURE, B. International trajectories of Brazilian companies: Empirical contribution to the debate on the importance of distance. International Journal of Emerging Markets, v.5, n.3-4, p. 358-376(19), 2010.

COOPER, D.; SCHINDLER, P. Métodos de pesquisa em administração. 7.ed. Porto Alegre: Bookman, 2003. 
CRESWELL, J. Research design: qualitative, quantitative and mixed method approaches. Estados Unidos: Sage Publications, 2003.

DaMATTA, Roberto. Que faz o Brasil, Brasil?. Rio de Janeiro: Editora Rocco, 8ed, 1997.

DENCKER, A. F. M., VIÁ, S. C. Pesquisa empírica em ciências humanas. São Paulo: Ed. Futura, p.115-187, 2001.

FARIAS, S.; SANTOS, R. Modelagem de equações estruturais e satisfação do consumidor: uma investigação teórica e prática. Revistas de Administração Contemporânea, v.4, n. 3, p. 107-132, set./dez. 2000.

FAUL, F.; ERDFELDER, E.; BUNCHENER, A.; LANG, A. G*Power 3: A flexible statistical power analysis program for the social, behavioral, and biomedical sciences. Behavior Research Methods, v.39 n.(2), p.175-191, 2007.

Statistical power analyses using $\mathrm{G}^{*}$ Power 3.1: Tests for correlation and regression analyses. Behavior Research Methods, v.41, n.(4), p.1149-1160, 2009.

FINESTONE, N., SNYMAN, M., Corporate South Africa - making multicultural knowledge sharing work. Journal of Knowledge Management, v.9 n.4, p.41-128, 2005.

FLEURY, M. T. L. O desvendar a cultura de uma organização - uma discussão metodológica, in: Cultura e poder nas organizações. São Paulo: Atlas, 1996.

FLEURY, A. Gestão empresarial para a internacionalização das empresas brasileiras. São Paulo: Atlas, 2010.

FLEURY, A. FLEURY, M. A. Internacionalização das empresas brasileiras: em busca de uma abordagem teórica para os lates movers. In: FLEURY, A. FLEURY, M. A. (org.) Internacionalização e os países emergentes. São Paulo: Atlas, 2007.

FLEURY, A.; FLEURY, M. A.; OLIVEIRA, M.; BORINI, F. Relatório da Pesquisa sobre Estratégias e Competências das Multinacionais Brasileiras. São Paulo: FAPESP, 2007.

FLICK, U. Uma introdução à pesquisa qualitativa. 2. ed. Porto Alegre: Bookman, 2004.

FORNELL, C.; LARCKER, D. Evaluating structural equation models with unobservable variables and measure. Journal of Marketing Research; feb. 1981.

FUNDAÇÃO DOM CABRAL. Ranking Transnacionais Brasileiras: investimentos no exterior crescem apesar da crise mundial. Relatório de pesquisa - RAMSEY, J.; BARAKAT, Lívia Lopes, 2009.

. Ranking Transnacionais Brasileiras: repensando as estratégias globais. Relatório de pesquisa - RAMSEY, J.; BARAKAT, Lívia Lopes; CRUZ, L.; CRETOIU, Sherban Leonardo, 2010.

GARVIN, D. Building learning organization in BARTLETT, C.; GHOSHAL, S. Transnational management: text, cases, and readings in cross-border management. 3ed. Boston: McGraw-Hill, 2000. 
GIBBS, G. Análise de dados qualitativos. Porto Alegre: Artmed, 2009.

GIL, A. C. Como elaborar projetos de pesquisa. 4ed. São Paulo: Atlas, 2002.

GHEMAWAT, P. Redefinindo estratégia global: Cruzando fronteiras em um mundo de diferenças que ainda importam. São Paulo: Bookman, 2008.

GODOY, A. S. Introdução à pesquisa qualitativa e suas possibilidades. Revista de Administração de Empresas, v.35, n.2, março-abril, p. 57-63, 1995.

GUPTA, A.; GOVINDARAJAN, V. Knowledge flows and the structure of control within multinational corporations. Academy of Management Review, v.16, n.4, p.768-792, 1996.

Knowledge flows within multinational corporations. Strategic Management Journal, apr. v.21, 2000.

KOGUT, B.; SINGH, H. The effect of national culture on the choice of entry mode. Journal of International Business Studies. fall, p.411-432, 1988.

HALL, S. A identidade cultural na pós-modernidade; tradução Tomaz Tadeu da Silva e Guacira Lopes Louro: Rio de Janeiro: DP\&A, 1998.

HAIR JR. J.; BABIN, B.; MONEY, A.; SAMOUEL, P. Fundamentos de métodos de pesquisa em Administração. Porto Alegre: Bookman, 2006.

HAIR JR. J.; ANDERSON, R.; TATHAM, R. BLACK, W. Análise multivariada de dados. Porto Alegre: Bookman, 2005.

HAYTON, J.; GEORGE, G.; ZAHRA, S. National Culture and Entrepreneurship:

A Review of Behavioral Research. Entrepreneurship: Theory \& Practice. v.26. n.(4), p.3352. 2002.

HILL, Charles W. L. International Business: Competing in the Global Marketplace. New York: Mc Graw Hill, 2005.

HITT, M.; IRELAND, R.; HOSKISSON, R. Administração estratégica: competitividade e globalização. 2ed. São Paulo: Thomson Learning: Cengage Learning, 2008.

HOFSTEDE, G. Culture's consequences: comparing values, behaviors, institutions and organizations across nations. Estados Unidos: Sage Publications, 2001.

Culturas e Organizações: Compreender a nossa programação mental. Portugal: Edições Sílabo, 2003.

HOFSTEDE, G.; HOFSTEDE, G. J. Cultures and Organizations: Software of the Mind, McGraw - Hill, 2005.

HOFSTEDE, G. et al. What do business leaders pursue? A study in fifteen countries. Journal of International Business Studies, v.33, n.4, p.785-808, oct/dec. 2002. 
HOFSTEDE, G.; HILAL, A.; MALVEZZI, S.; TANURE, B.; VINKEN, H. Comparing regional cultures within a country: lessons from Brazil. Journal of Cross-Cultural Psychology, v.41, p.336, 2010.

HOLDEN, Nigel. Knowledge management: raising the specter of the cross-cultural dimension. Knowledge and Process Management, v.8, n.3., jul/sep, 2001.

HOLDEN, N.; VON KORTZFLEISCH, H. Why cross-cultural knowledge transfer is a form of translation in more way than you think. Knowledge and Process Management, v. 11, n. 2, p. 127-136, 2004.

HOLSAPPLE, C.; JOSHI, K. A knowledge management ontology. In: Handbook on knowledge management I. org: Clyde W. Holsapple, springer, 2003.

HOUSE, R.J., HANGES, P.J., JAVIDAN, M., DORFMAN, P., GUPTA, V. Cultures, Leadership, and Organizations: GLOBE Study of 62 Societies, Sage Publications: Newbury Park, CA, 2004.

INGLEHART, R. Modernization and postmodernization - cultural, economic and political change in 43 societies. New Jersey: Princeton University Press, 1997.

JARVIS, C. B.; MACKENZIE, S. B.; PODSAKOFF, P. M. A critical review of construct indicators and measurement model misspecification in Marketing and Consumer Research. Journal of Consumer Research, v.30, n.2, p.199-218, set. 2003.

LANE. Absortive capacity, learning and performance in international joint ventures-Strategic Management Journal, v.22, 2001.

LEUNG, Kwok, BHAGAT, Rabi S, BUCHAN, Nancy R, EREZ, Miriam, GIBSON Cristina B. Culture and international business: recent advances and their implications for future research. Journal of International Business Studies, p.357-378, 2005.

LITTLE, T.; LINDENBERG, U.; NESSELROAD, J. On selecting indicators for Multivariate Measurement and Modeling with latent variables: when "good" indicators are bad and "bad" indicators are good. Psychological Methods, v.4, n.2, 1999.

MALHOTRA, N. Pesquisa de marketing: uma orientação aplicada. 3ed. Porto Alegre: Bookman, 2004.

MARCONI, M. A.; LAKATOS, E. M. Metodologia do Trabalho Científico. São Paulo: Atlas, 2001.

MARSCHAN-PIEKKARI, R.; WELCH, C.; PENTTINEN, H.; TAHVANAINEN, M. Interviewing in the multinational corporation: challenges of the organizational context. In: MARSCHAN-PIEKKARI, R.; WELCH, C. Handbook of qualitative research methods for international business. London: Edward Elgar, 2004.

MEYER, K.; WRIGHT, M.; PRUTHI, S. Managing knowledge in foreign entry strategies: a resource-based analysis. Strategic Management Journal, v.30, p.557-574, 2009. 
MINBAEVA, D.; PEDERSEN, T.; BOJÖRKMAN, I.; FEY, C.; PARK, H. MNC knowledge transfer, subsidiary absorptive capacity and HRM. Journal of International Business Studies, v.34, 586-599, 2003.

MINAYO, Maria C. S. O desafio do conhecimento: pesquisa qualitativa em saúde. São Paulo: Ed. Abrasco, p. 9-197, 2000.

MURITIBA, P. Estratégia internacional de gestão de pessoas nas multinacionais brasileiras. São Paulo, 2009. Tese (Doutorado em Administração). Programa de PósGraduação em Administração. Faculdade de Economia, Administração e Contabilidade da Universidade de São Paulo.

MORAN, R. T.; HARRIS, P. R.; STRIPP, W. G. Desenvolvendo organizações globais: como preparar sua empresa para a competição mundial. São Paulo: Futura, 1996.

MOTTA, F. C. P., CALDAS, M. P. Cultura organizacional e cultura brasileira. São Paulo: Atlas, 1997.

NEWMAN, B. Agents, artifacts and transformations: the foundations of knowledge flows in Handbook on knowledge management I. org: Clyde W. Holsapple, springer, 2003.

NIÑO, F. M. A oferta de serviços turísticos nos ambientes de comércio online e offline. São Paulo, 2009. Tese (Doutorado em Administração). Programa de Pós-Graduação em Administração. Faculdade de Economia, Administração e Contabilidade da Universidade de São Paulo.

NOHRIA, Nitin; GHOSHAL, Sumantra. The differentiated network: organizing multinational corporations for value creation. San Francisco: Jossey-Bass, 1997.

NONAKA, I.; TAKEUCHI, H.. Criação de conhecimento na empresa: como as empresas japonesas geram a dinâmica da inovação. Rio de Janeiro: Campus, 1997.

OUCHI, W.; WILKINS, A. Organizational culture. Annual Review of Sociology, 1985.

OLIVEIRA JUNIOR, M. Internacionalização de Empresas Brasileiras: o papel da subsidiária. São Paulo, 2009. Tese de Livre Docência. Faculdade de Economia, Administração e Contabilidade da Universidade de São Paulo.

OLIVIERA JUNIOR, M.; BORINI, F. Estratégias e mecanismos para transferência de conhecimento nas multinacionais brasileiras In: FLEURY, A. Gestão empresarial para a internacionalização das empresas brasileiras. São Paulo: Atlas, 2010.

PAULEEN, D.J.; MURPHY, P. In: Praise of cultural bias, MIT Sloan Management Review. v.46, n.2, 2005.

PRAHALAD, C.; DOZ, Y. An approach to strategic control in MNCs. Sloan Management Review, summer, p.5-13, 1981.

PENG, M. Estratégia Global. São Paulo: Thomson Learning, 2008.

PETTIGREW, A. On studying organizacional cultures. Administrative Science Quarterly, v.24, n.(4), 1979. 
POHLMANN, M. Análise de Conglomerados. In: CORRAR, L.; PAULO, E.; DIAS FILHO, J. Análise multivariada para os cursos de administração, ciências contábeis e economia. São Paulo: Atlas, 2007.

REVISTA VALOR ECONÔMICO ESPECIAL, 2010. Multinacionais brasileiras: as mais internacionalizadas.

RINGLE, C. M.; WENDE, S.; WILL, A. SmartPLS 2.0 M3 (beta). Germany: University of Hamburg, 2005. Disponível em: <http://www.smartpls.de $>$.

RONEN S.; SHENKAR, O. Clustering countries on attitudinal dimensions: a review and synthesis. Academy of Management Review, v.80, n.(609), p.435-454, 1985.

ROOT, F. Entry Strategies for International Markets. San Francisco, USA: JOSSEY BASS, 1994.

RUGMAN, A.; VERBEKE, A. Subsidiary-specific advantages in multinational enterprises, Strategic Management Journal, v.22, p.237-250, 2001.

SAMPIERI, R. H.; COLLADO, C.F.; LUCIO, P.B. Metodologia de Pesquisa. 3ed. São Paulo: Mc Graw-Hill, 2006.

SILVA, N.; URBAN, T.; BERLATO, H. Internacionalização: Estratégia de Gestão Intercultural de Pessoas In: Encontro de Estudos em estratégia - 3E's, 2009. Recife, anais eletrônicos. Recife: 3E's, 2009.

SIMONIN, B. Ambiguity and the process of knowledge transfer in strategic alliances, Strategic Management Journal. v.20, n.7, p.595-623, 1999.

SCHEIN, E. H. Organizational culture and leadership. 2ed. San Francisco: Jossey-Bass, 1989.

2001.

Guia de sobrevivência da cultura corporativa. Rio de Janeiro: José Olympio,

SMITH, P., DUGAN, S.; TROMPENAARS, F. National culture and the values of organizational employees: A dimensional analysis across 43 nations. Journal of CrossCultural Psychology, v.27, p.231-264, 1996.

SCHMITZ, A. WEG, 40 anos. Jaraguá do Sul: Weg Indústrias S.A., 2001.

SMIRCICH, Linda. Concepts of Culture and Organizational Analysis. Administrative Science Quarterly, v.28, 1983.

SOUZA, C. Uso organizacional da tecnologia de informação: um estudo sobre a avaliação do grau de informatização de empresas industriais paulistas. São Paulo, 2004. Tese (Doutorado em Administração). Programa de Pós-Graduação em Economia, Faculdade de Economia, Administração e Contabilidade da Universidade de São Paulo.

SUDMAN, S.; BRADBURN, N. Asking questions. San Francisco: Jossey-Bass, 1982. 
SUMELIUS, J.; SARALA, R. Knowledge development in MNC subsidiaries: the influence of MNC internal and external knowledge and controls mechanisms. Thunderbird International Business Review, v.50, n.4, July/August, 2008.

TAKEUCHI, H.; NONAKA, I. Gestão do conhecimento. Porto Alegre: Bookman, 2008.

TANURE, B. Gestão à brasileira: uma comparação entre América Latina, Estados Unidos, Europa e Ásia. São Paulo: Atlas, 2007.

TANURE, B., DUARTE, R.. O impacto da diversidade cultural na gestão internacional. In: TANURE, Betania, DUARTE, Roberto Gonzalez (Orgs.). Gestão Internacional. São Paulo: Saraiva, 2006.

TANURE, B.; CYRINO, A.; PENIDO, E. Estratégias de internacionalização: evidências e reflexões sobre as empresas brasileiras IN FLEURY, A. FLEURY, M. A. (org.) Internacionalização e os países emergentes. São Paulo: Atlas, 2007.

THEVENET, M. A cultura de empresa hoje em dia. Revista de Administração. São Paulo, v.26, n.2, 1991.

TUNG, R. The cross-cultural research imperative: the need to balance cross-national and intra-national diversity. Journal of International Business Studies, v.39, p.41-46, 2008.

VANCE, Charles M.; PAIK, Yongson. Managing a Global Workforce-Challenges and Opportunities. London: M.E. Sharpe, 2006.

VOEL, S.; HAN, C. Managing knowledge sharing in China: the case of Siemens ShareNet. Journal of Knowledge Management, v.9, n.3, p.51-63, 2005.

ZWICKER, R.; SOUZA, C.; BIDO, D. Uma revisão do modelo do grau de informatização de empresas: novas propostas de estimação e modelagem usando PLS (partial least squares). In: ENCONTRO DA ASSOCIAÇÃO NACIONAL DE PÓS-GRADUAÇÃO E PESQUISA EM ADMINISTRAÇÃO - ENANPAD 32, 2008. Rio de Janeiro, anais eletrônicos. Rio de Janeiro: ANPAD, 2008. 1 CD-ROM.

ZHU, Z. Knowledge management: towards a universal concept or cross-cultural contexts? Knowledge Management Research \& Practice, v.2, n.2, p.67-79(13), August 2004.

WEG S.A. disponível em: http://www.weg.net/br, acesso em 10 de outubro de 2010.

WETZELS, M.; ODEKERKEN-SCHRODER, G.; OPPEN, C. Using PLS path modeling for assessing hierarchical construct models: guidelines and empirical illustration. MIS Quarterly, v.33, n.1, p.177-195/March, 2009.

WOOD, T. Cultura organizacional brasileira IN: Mudança organizacional: aprofundando temas atuais em administração de empresas. Thomaz Wood Jr. (Coord). São Paulo: Atlas, 1995. 


\section{APÊNDICES}

APÊNDICE 1 - ROTEIRO DE ENTREVISTA SEMI-ESTRUTURADO

APÊNDICE 2 - QUESTIONÁRIO AUTO-PREENCHIDO PARA SUBSIDIÁRIAS

APÊNDICE 3 - RESULTADOS DOS CONGLOMERADOS DE CULTURA

APÊNDICE 4 - MODELO DE MENSURAÇÃO FINAL

APÊNDICE 5 - RESULTADOS DOS CONGLOMERADOS DE INICIATIVA 


\section{APÊNDICE 1 - ROTEIRO DE ENTREVISTA SEMI-ESTRUTURADO}

\section{Perfil do Respondente}

Formação:

Cargo:

Tempo no cargo:

Tempo na empresa:

\section{Processo de internacionalização}

1- Porque a WEG optou pela aquisição de plantas no exterior ao invés de iniciar uma do zero?

2- Quais critérios foram utilizados para a escolha dos países?

3- Em algum momento a cultura do país foi um fator relevante para a tomada de decisão? Por quê?

\section{Transferência de conhecimento entre matriz e subsidiária}

4 - Como ocorre o processo de transferência de conhecimento entre a matriz e as unidades da WEG?

5 - Quais os principais meios / mecanismos utilizados?

- Realização de reuniões com os principais executivos da matriz

- Criação de manuais para orientar a implementação e divulgação para as unidades

- Expatriações de executivos brasileiros para as unidades

- Realização de treinamentos na matriz

- Incentivo às práticas de benchmarking entre todas as unidades e a matriz

- Existe um banco de melhores práticas entre todas as unidades e a matriz

6 - Existe alguma dificuldade nesse processo de transferência de conhecimentos da matriz para as unidades? Existe algum tipo de barreira ou resistência?

- Resistência cultural por parte da Unidade ou da Matriz

- Crença de que a atividade não é importante e sua transferência não origina melhorias de eficiência para a corporação

- O compartilhamento da atividade não é bem visto pois demanda a alocação de tempo, pessoal e recursos para benefício de outras unidades ou matriz

- Receio em perder o controle da atividade

- Inexistência de incentivos para estimular o compartilhamento do conhecimento

- Existem distorções na transmissão das atividades devido à estrutura organizacional

- Síndrome do "não inventado aqui", ou seja, a matriz ou as outras subsidiárias apresentam forte relutância em aceitar a atividade criada na sua Unidade

\section{Cultura local e cultura organizacional}


7 - Quais são as principais características da cultura organizacional da WEG?

8 - Existe influência positiva e/ou negativa da cultura organizacional da WEG (matriz) na gestão das unidades?

9 - Quais são os aspectos de destaque (positivo e negativo) da cultura dos países onde estão as unidades da WEG?

10 - De que maneira, esses aspectos influenciam (facilitam ou dificultam) o processo de transferência de conhecimento entre as unidades e a matriz brasileira?

11 - De que maneira, esses aspectos culturais influenciam (facilitam ou dificultam) a gestão da unidade?

12 - Existem brasileiros expatriados? Com qual objetivo principal?

13 - Como você percebe o relacionamento dos estrangeiros com os brasileiros?

\section{Oportunidades de negócios}

14 - As Unidades identificam novas oportunidades de negócios para a multinacional como um todo (matriz e subsidiárias)?

15 - As Unidades têm contato direto com clientes, fornecedores, entidades governamentais e associações setoriais? Buscam oportunidades a partir destes contatos?

16 - De que maneira a transferência de conhecimento entre a matriz e a Unidade facilita e/ou dificulta a identificação dessas novas oportunidades?

17 - De que maneira, os aspectos culturais do país, onde a Unidade está localizada, influenciam (facilitam ou dificultam) a busca e identificação de oportunidades?

18 - A matriz brasileira reconhece as oportunidades de negócios identificadas pela Unidade? Como? 


\section{APÊNDICE 2 - QUESTIONÁRIO AUTO-PREENCHIDO PARA SUBSIDIÁRIAS}

Prezado (a) Senhor (a):

A internacionalização de empresas brasileiras é o tema central da pesquisa da tese referente ao Doutorado em Administração que curso na Universidade de São Paulo.

Desta maneira, os seus relatos sobre esta Unidade Internacional da WEG serão de extrema valia para o objetivo principal do estudo que é compreender os aspectos culturais do país e identificar como ocorre o processo de transferência de conhecimento entre a subsidiária e a matriz, bem como os impactos no negócio da empresa.

Para responder ao questionário são necessários aproximadamente 20 minutos. Assim, solicito sua colaboração, não sendo obrigatória sua identificação.

No caso de dúvidas ou sugestões, por gentileza, encaminhá-las pelo email: nbertoia@usp.br ou natacha@uol.com.br.

Muito obrigada.

Natacha Bertoia da Silva

\section{Perfil do Respondente}

Formação:

\section{Cargo:}

Nacionalidade:

Tempo na empresa (na subsidiária): |

\section{Perfil da Unidade (Subsidiária)}

Nome ou Local da Unidade:

Principal atuação: 
País da Unidade:

Origem da Unidade: $\square$ joint venture $\square$ greenfield $\square$ aquisição Outros

\section{Perguntas:}

\section{1- Brasileiros expatriados:}

a) Existem brasileiros trabalhando na Unidade?

$\mathbb{C} \operatorname{Sim} \mathbb{C}$ Não

Os trabalhadores locais gostam de trabalhar com os brasileiros?

$\mathbb{C} \operatorname{Sim} \mathbb{E}$ Não

C Comente:

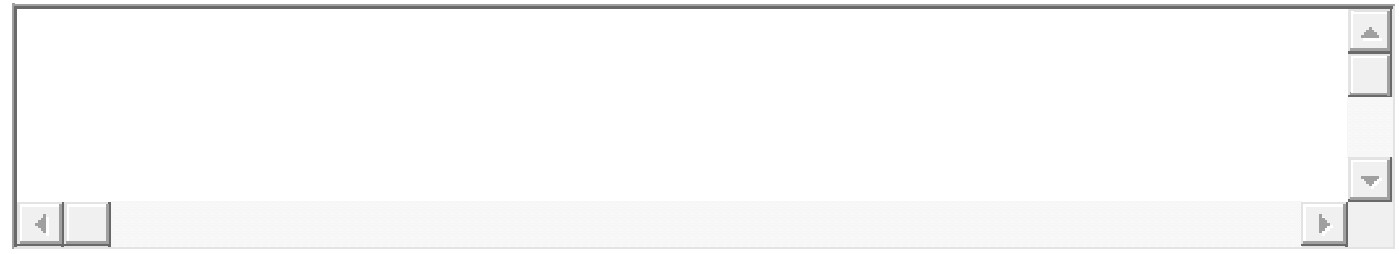

\section{2 - Cultura local e cultura organizacional}

a) Existe influência positiva e/ou negativa da cultura organizacional da WEG (matriz) na gestão da unidade?

$\ulcorner$ Influência positiva $\sqsubset \quad$ Influência negativa

Comente:

b) Como as características culturais brasileiras e do país onde você trabalha influenciam a gestão da unidade? 


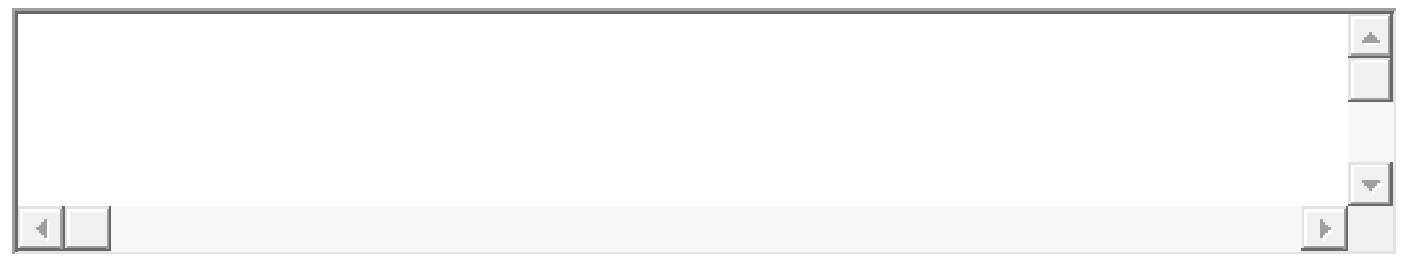

3 - Transferência de conhecimento (inclusive atividades) entre subsidiária e matriz

a) Dentre os mecanismos existentes de transferência de conhecimento, assinale os pertinentes a realidade da Unidade:

\begin{tabular}{|c|c|}
\hline Mecanismos & $\begin{array}{c}\text { Unidade para } \\
\text { a Matriz }\end{array}$ \\
\hline Realizamos reuniões com os principais executivos da matriz & Г $\mathrm{SIM}$ \\
\hline $\begin{array}{l}\text { Criamos manuais para orientar a implementação e divulgamos para a } \\
\text { matriz }\end{array}$ & $\Gamma \mathrm{SIM}$ \\
\hline Enviamos executivos para a matriz & $\bar{\Gamma} \mathrm{SIM}$ \\
\hline Ministramos treinamentos na matriz & $\Gamma \mathrm{sIM}$ \\
\hline Existe um benchmarking entre todas as unidades e a matriz & $\Gamma \mathrm{SIM}$ \\
\hline $\begin{array}{l}\text { Existe um banco de melhores práticas entre todas as unidades e a } \\
\text { matriz }\end{array}$ & $\Gamma \mathrm{SIM}$ \\
\hline
\end{tabular}

Comente:

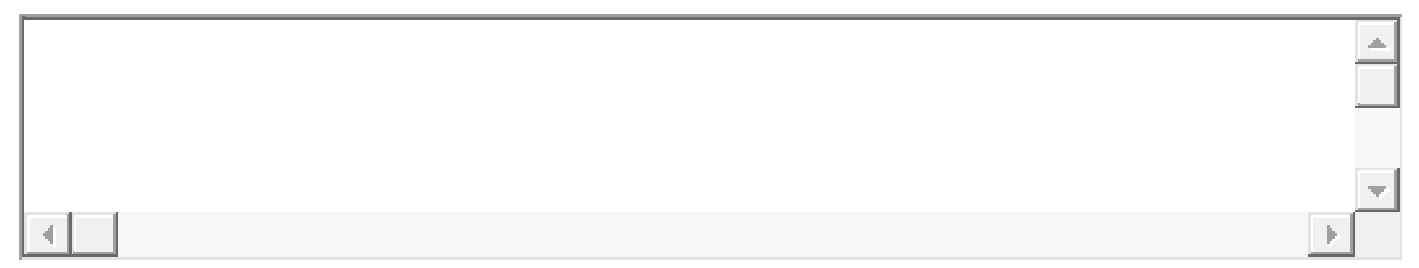

b) Existe alguma dificuldade nesse processo de transferência de conhecimentos da subsidiária para a matriz?

$\mathbb{C} \operatorname{Sim} \mathbb{C}$ Não

c) Se sim, assinale as barreiras existentes: 


\begin{tabular}{|c|c|}
\hline Barreiras & $\begin{array}{l}\text { Subsidiária } \\
\text { para matriz }\end{array}$ \\
\hline Resistência cultural por parte da Unidade ou da Matriz & $\Gamma \quad \mathrm{SIM}$ \\
\hline $\begin{array}{l}\text { Crença, por parte da Unidade, de que a atividade não é importante e sua } \\
\text { transferência não origina melhorias de eficiência para a corporação }\end{array}$ & $\Gamma \operatorname{siM}$ \\
\hline $\begin{array}{l}\text { O compartilhamento da atividade não é bem visto pela Unidade, pois } \\
\text { demanda a alocação de tempo, pessoal e recursos para benefício de outras } \\
\text { unidades ou matriz }\end{array}$ & $\Gamma \operatorname{SIM}$ \\
\hline Receio por parte da Unidade em perder o controle da atividade & $\Gamma_{\mathrm{SIM}}$ \\
\hline $\begin{array}{l}\text { Inexistência de incentivos por parte da matriz para estimular o } \\
\text { compartilhamento do conhecimento }\end{array}$ & $\overline{\Gamma \mathrm{SIM}}$ \\
\hline $\begin{array}{l}\text { Existem distorções na transmissão das atividades devido à estrutura } \\
\text { hierárquica na Corporação }\end{array}$ & Г $\mathrm{SIM}$ \\
\hline $\begin{array}{l}\text { Síndrome do "não inventado aqui”, ou seja, a matriz ou as outras } \\
\text { subsidiárias apresentam forte relutância em aceitar a atividade criada na } \\
\text { sua Unidade }\end{array}$ & $\Gamma \operatorname{SIM}$ \\
\hline
\end{tabular}

Comente:

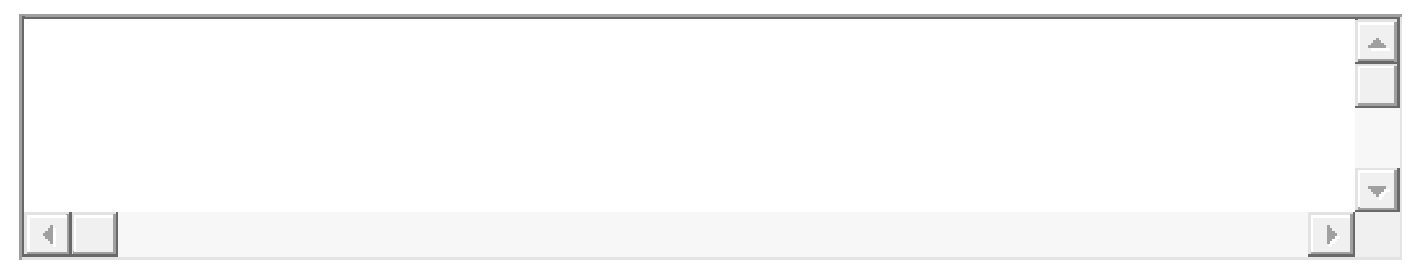

\section{4 - Oportunidades de negócios}

a) A Unidade identifica novas oportunidades de negócios para a multinacional como um todo (matriz e subsidiárias)?

$\boldsymbol{C}_{\operatorname{Sim}} \boldsymbol{C}$ Não

Comente:

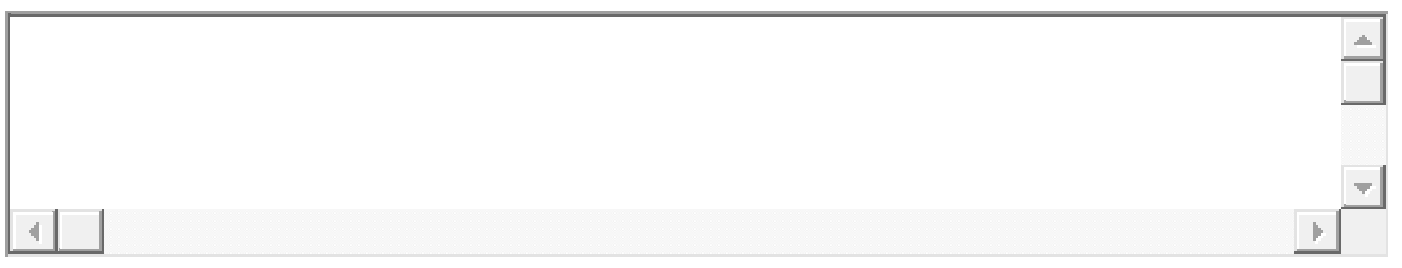

b) No seu contexto local, a Unidade tem contato direto com: 


\begin{tabular}{|c|c|}
\hline Clientes & $\ulcorner\mathrm{SIM}$ \\
\hline Fornecedores & $\Gamma \quad \mathrm{SIM}$ \\
\hline Entidades governamentais & $\Gamma \mathrm{SIM}$ \\
\hline Associações setoriais & $\Gamma \mathrm{SIM}$ \\
\hline Outros & \\
\hline
\end{tabular}

c) A Unidade identifica oportunidades de negócios a partir desses contatos?

C $\operatorname{Sim}$ C Não

Comente:

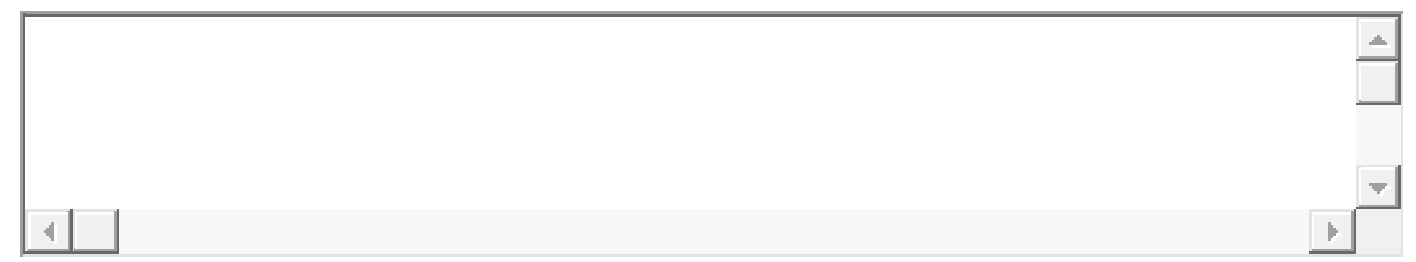

d) A transferência de conhecimento entre a matriz e a Unidade facilita e/ou dificulta a identificação dessas novas oportunidades?

\begin{tabular}{|l|l|}
\hline Facilita & $\Gamma$ \\
& SIM \\
\hline Dificulta & $\Gamma$ \\
& SIM \\
\hline
\end{tabular}

Comente:

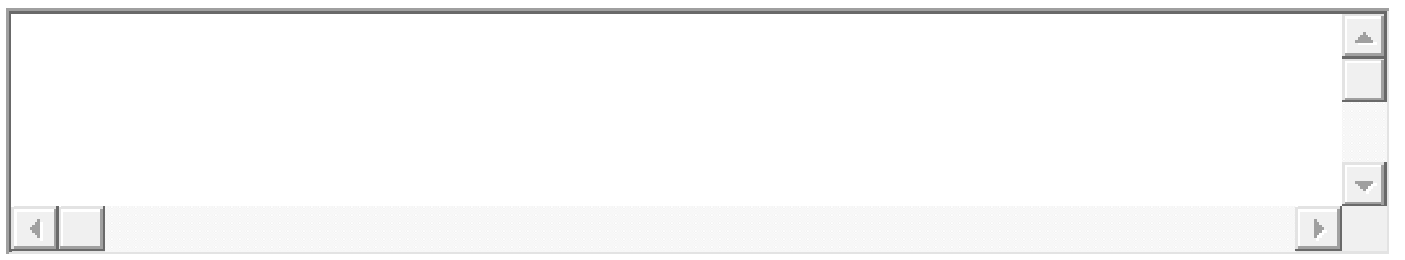

e) A matriz brasileira reconhece as oportunidades identificadas pela Unidade?

$\mathbb{C} \operatorname{Sim} \mathbb{C}$ Não

Comente:

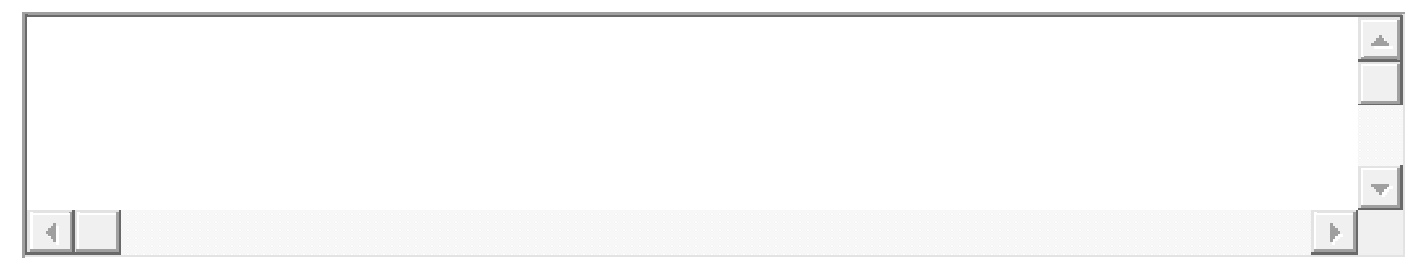


Comentários Adicionais :

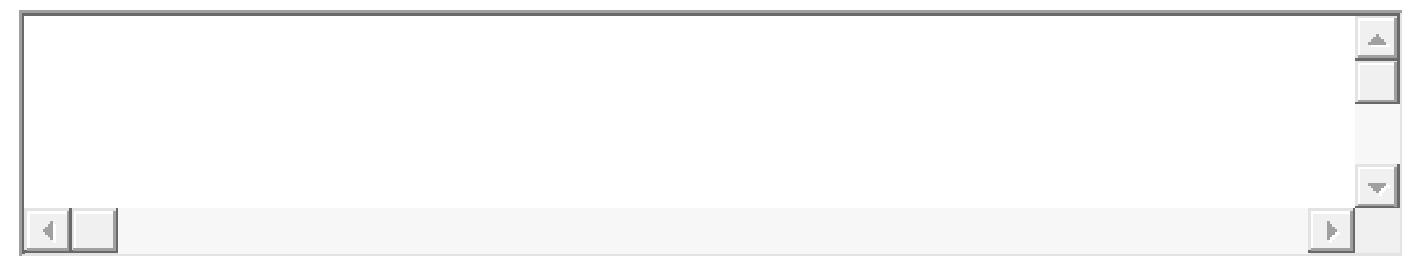


APÊNDICE 3 - RESULTADOS DOS CONGLOMERADOS DE CULTURA

Agglomeration Schedule

\begin{tabular}{|c|c|c|c|c|c|c|}
\hline \multirow[b]{2}{*}{ Stage } & \multicolumn{2}{|c|}{ Cluster Combined } & \multirow[b]{2}{*}{ Coefficients } & \multicolumn{2}{|c|}{$\begin{array}{c}\text { Stage Cluster First } \\
\text { Appears }\end{array}$} & \multirow[b]{2}{*}{ Next Stage } \\
\hline & Cluster 1 & Cluster 2 & & Cluster 1 & Cluster 2 & \\
\hline 1 & 19 & 20 & 150,000 & 0 & 0 & 9 \\
\hline 2 & 3 & 17 & 161,000 & 0 & 0 & 13 \\
\hline 3 & 9 & 22 & 194,000 & 0 & 0 & 13 \\
\hline 4 & 10 & 21 & 206,000 & 0 & 0 & 7 \\
\hline 5 & 4 & 18 & 224,000 & 0 & 0 & 15 \\
\hline 6 & 5 & 13 & 226,000 & 0 & 0 & 14 \\
\hline 7 & 8 & 10 & 253,500 & 0 & 4 & 11 \\
\hline 8 & 2 & 12 & 285,000 & 0 & 0 & 17 \\
\hline 9 & 6 & 19 & 371,500 & 0 & 1 & 18 \\
\hline 10 & 15 & 23 & 422,000 & 0 & 0 & 12 \\
\hline 11 & 8 & 16 & 457,333 & 7 & 0 & 15 \\
\hline 12 & 1 & 15 & 550,500 & 0 & 10 & 14 \\
\hline 13 & 3 & 9 & 605,750 & 2 & 3 & 16 \\
\hline 14 & 1 & 5 & 631,167 & 12 & 6 & 21 \\
\hline 15 & 4 & 8 & 639,750 & 5 & 11 & 16 \\
\hline 16 & 3 & 4 & 571,688 & 13 & 15 & 19 \\
\hline 17 & 2 & 14 & 767,250 & 8 & 0 & 18 \\
\hline 18 & 2 & 6 & 1094,778 & 17 & 9 & 19 \\
\hline 19 & 2 & 3 & 1286,931 & 18 & 16 & 20 \\
\hline 20 & 2 & 7 & 2871,117 & 19 & 0 & 21 \\
\hline 21 & 1 & 2 & 3440,723 & 14 & 20 & 22 \\
\hline 22 & 1 & 11 & 5432,707 & 21 & 0 & 0 \\
\hline
\end{tabular}

Number of Cases in each Cluster

\begin{tabular}{|ll|r|}
\hline Cluster & 1 & 5,000 \\
& 2 & 16,000 \\
& 3 & 2,000 \\
Valid & & 23,000 \\
Missing & &, 000 \\
\hline
\end{tabular}

Case Processing Summary

\begin{tabular}{|c|c|c|c|c|c|c|}
\hline & \multicolumn{6}{|c|}{ Cases } \\
\hline & \multicolumn{2}{|c|}{ Valid } & \multicolumn{2}{|c|}{ Missing } & \multicolumn{2}{|c|}{ Total } \\
\hline & $\mathrm{N}$ & Percent & $\mathrm{N}$ & Percent & $\mathrm{N}$ & Percent \\
\hline $\begin{array}{l}\text { pais * Cluster } \\
\text { Number of Case }\end{array}$ & 23 & $100,0 \%$ & 0 &, $0 \%$ & 23 & $100,0 \%$ \\
\hline
\end{tabular}


Relação dos países por conglomerados

\begin{tabular}{|c|c|c|c|c|c|}
\hline & \multicolumn{3}{|c|}{ Cluster Number of Case } & \multirow[b]{2}{*}{ Total } \\
\hline & & 1 & 2 & 3 & \\
\hline \multirow[t]{23}{*}{ pais } & África do Sul & 1 & 0 & $\overline{0}$ & $\overline{1}$ \\
\hline & Alemanha & 1 & 0 & 0 & 1 \\
\hline & Angola & 0 & 1 & 0 & 1 \\
\hline & Argentina & 0 & 1 & 0 & 1 \\
\hline & Bolívia & 0 & 1 & 0 & 1 \\
\hline & Brasil & 0 & 1 & 0 & 1 \\
\hline & Canadá & 1 & 0 & 0 & 1 \\
\hline & Chile & 0 & 1 & 0 & 1 \\
\hline & China & 0 & 0 & 1 & 1 \\
\hline & Colômbia & 0 & 1 & 0 & 1 \\
\hline & Emirados & 0 & 1 & 0 & 1 \\
\hline & Equador & 0 & 1 & 0 & 1 \\
\hline & Eslováquia & 0 & 0 & 1 & 1 \\
\hline & Espanha & 0 & 1 & 0 & 1 \\
\hline & Estados Unidos & 1 & 0 & 0 & 1 \\
\hline & França & 0 & 1 & 0 & 1 \\
\hline & Itália & 1 & 0 & 0 & 1 \\
\hline & México & 0 & 1 & 0 & 1 \\
\hline & Paraguai & 0 & 1 & 0 & 1 \\
\hline & Peru & 0 & 1 & 0 & 1 \\
\hline & Portugal & 0 & 1 & 0 & 1 \\
\hline & Uruguai & 0 & 1 & 0 & 1 \\
\hline & Venezuela & 0 & 1 & 0 & 1 \\
\hline Total & & 5 & 16 & 2 & 23 \\
\hline
\end{tabular}


APÊNDICE 4 - MODELO DE MENSURAÇÃO FINAL

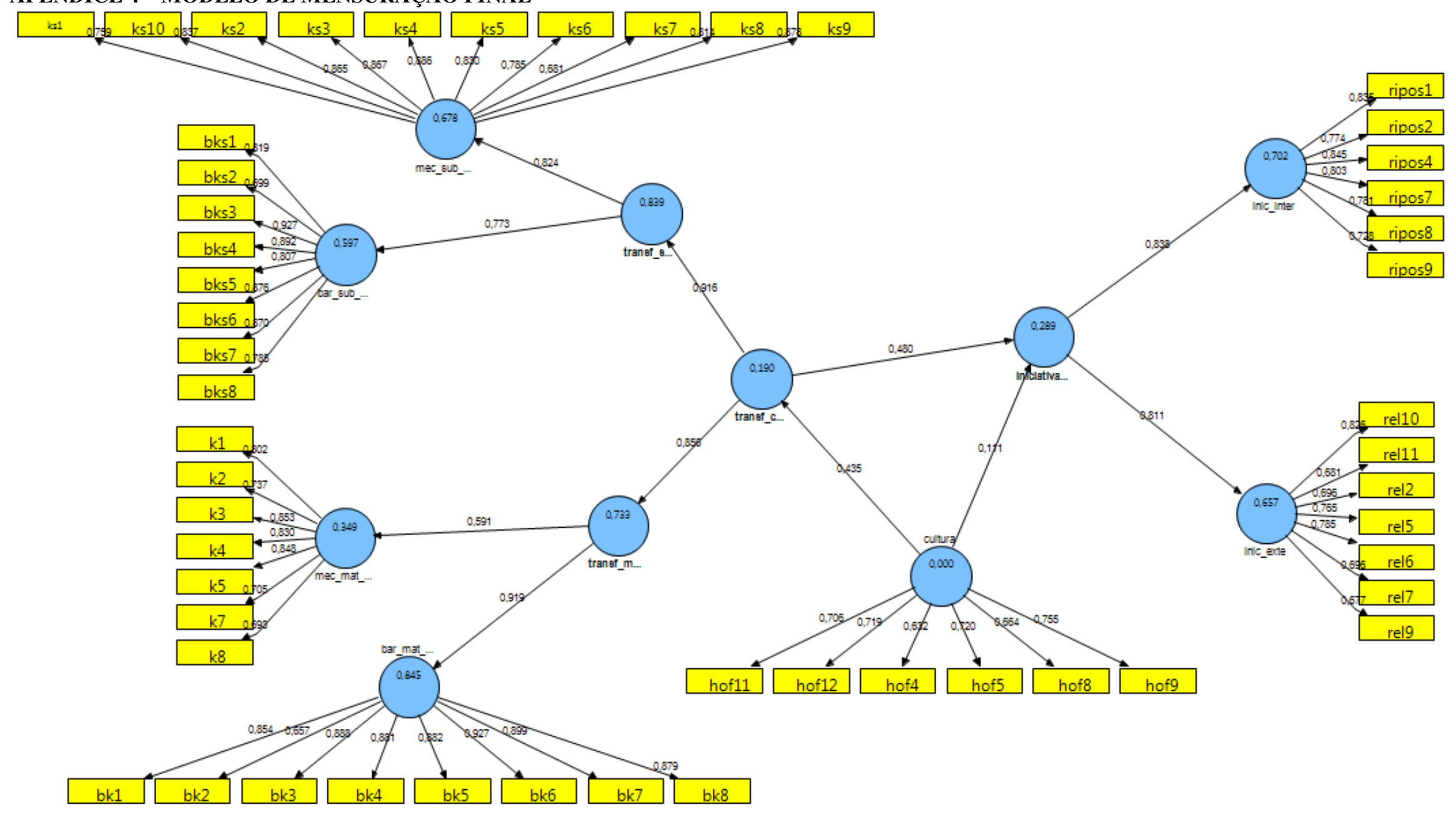


Agglomeration Schedule

\begin{tabular}{|c|c|c|c|c|c|c|}
\hline \multirow[b]{2}{*}{ Stage } & \multicolumn{2}{|c|}{ Cluster Combined } & \multirow[b]{2}{*}{ Coefficients } & \multicolumn{2}{|c|}{$\begin{array}{c}\text { Stage Cluster First } \\
\text { Appears }\end{array}$} & \multirow[b]{2}{*}{ Next Stage } \\
\hline & Cluster 1 & Cluster 2 & & Cluster 1 & Cluster 2 & \\
\hline 1 & 15 & 16 & ,005 & 0 & 0 & 10 \\
\hline 2 & 58 & 59 &, 116 & 0 & 0 & 4 \\
\hline 3 & 39 & 41 & ,195 & 0 & 0 & 16 \\
\hline 4 & 58 & 60 & ,347 & 2 & 0 & 16 \\
\hline 5 & 32 & 42 & ,361 & 0 & 0 & 21 \\
\hline 6 & 64 & 65 & ,461 & 0 & 0 & 26 \\
\hline 7 & 1 & 56 & ,470 & 0 & 0 & 29 \\
\hline 8 & 27 & 50 & ,722 & 0 & 0 & 32 \\
\hline 9 & 22 & 35 & ,756 & 0 & 0 & 20 \\
\hline 10 & 8 & 15 & 813 & 0 & 1 & 30 \\
\hline 11 & 2 & 24 & ,828 & 0 & 0 & 34 \\
\hline 12 & 12 & 14 & ,845 & 0 & 0 & 25 \\
\hline 13 & 33 & 57 & ,862 & 0 & 0 & 19 \\
\hline 14 & 10 & 62 & ,968 & 0 & 0 & 29 \\
\hline 15 & 46 & 47 & 970 & 0 & 0 & 35 \\
\hline 16 & 39 & 58 & 1,016 & 3 & 4 & 25 \\
\hline 17 & 43 & 55 & 1,035 & 0 & 0 & 60 \\
\hline 18 & 3 & 37 & 1,064 & 0 & 0 & 37 \\
\hline 19 & 33 & 48 & 1,125 & 13 & 0 & 43 \\
\hline 20 & 22 & 34 & 1,190 & 9 & 0 & 33 \\
\hline 21 & 18 & 32 & 1,275 & 0 & 5 & 26 \\
\hline 22 & 5 & 13 & 1,289 & 0 & 0 & 27 \\
\hline 23 & 51 & 54 & 1,371 & 0 & 0 & 49 \\
\hline 24 & 30 & 66 & 1,375 & 0 & 0 & 39 \\
\hline 25 & 12 & 39 & 1,482 & 12 & 16 & 33 \\
\hline 26 & 18 & 64 & 1,531 & 21 & 6 & 35 \\
\hline 27 & 5 & 49 & 1,586 & 22 & 0 & 43 \\
\hline 28 & 26 & 36 & 1,588 & 0 & 0 & 46 \\
\hline 29 & 1 & 10 & 1,725 & 7 & 14 & 50 \\
\hline 30 & 8 & 63 & 1,848 & 10 & 0 & 55 \\
\hline 31 & 23 & 45 & 1,904 & 0 & 0 & 32 \\
\hline 32 & 23 & 27 & 1,964 & 31 & 8 & 39 \\
\hline 33 & 12 & 22 & 1,974 & 25 & 20 & 38 \\
\hline 34 & 2 & 61 & 2,042 & 11 & 0 & 40 \\
\hline 35 & 18 & 46 & 2,077 & 26 & 15 & 44 \\
\hline 36 & 20 & 25 & 2,191 & 0 & 0 & 41 \\
\hline 37 & 3 & 9 & 2,194 & 18 & 0 & 42 \\
\hline 38 & 12 & 19 & 2,234 & 33 & 0 & 47 \\
\hline 39 & 23 & 30 & 2,320 & 32 & 24 & 48 \\
\hline 40 & 2 & 31 & 2,448 & 34 & 0 & 52 \\
\hline 41 & 20 & 29 & 2,519 & 36 & 0 & 57 \\
\hline 42 & 3 & 11 & 2,604 & 37 & 0 & 53 \\
\hline
\end{tabular}




\begin{tabular}{|c|c|c|c|c|c|c|}
\hline 43 & 5 & 33 & 2,778 & 27 & 19 & 45 \\
\hline 44 & 18 & 53 & 3,015 & 35 & 0 & 51 \\
\hline 45 & 5 & 6 & 3,077 & 43 & 0 & 52 \\
\hline 46 & 21 & 26 & 3,283 & 0 & 28 & 48 \\
\hline 47 & 12 & 28 & 3,537 & 38 & 0 & 49 \\
\hline 48 & 21 & 23 & 3,627 & 46 & 39 & 54 \\
\hline 49 & 12 & 51 & 3,690 & 47 & 23 & 51 \\
\hline 50 & 1 & 7 & 3,742 & 29 & 0 & 58 \\
\hline 51 & 12 & 18 & 4,342 & 49 & 44 & 53 \\
\hline 52 & 2 & 5 & 4,925 & 40 & 45 & 54 \\
\hline 53 & 3 & 12 & 5,201 & 42 & 51 & 55 \\
\hline 54 & 2 & 21 & 6,241 & 52 & 48 & 62 \\
\hline 55 & 3 & 8 & 6,636 & 53 & 30 & 57 \\
\hline 56 & 38 & 40 & 6,768 & 0 & 0 & 61 \\
\hline 57 & 3 & 20 & 7,893 & 55 & 41 & 58 \\
\hline 58 & 1 & 3 & 8,666 & 50 & 57 & 59 \\
\hline 59 & 1 & 52 & 9,874 & 58 & 0 & 61 \\
\hline 60 & 43 & 44 & 10,283 & 17 & 0 & 62 \\
\hline 61 & 1 & 38 & 10,431 & 59 & 56 & 64 \\
\hline 62 & 2 & 43 & 10,839 & 54 & 60 & 63 \\
\hline 63 & 2 & 17 & 13,710 & 62 & 0 & 64 \\
\hline 64 & 1 & 2 & 16,082 & 61 & 63 & 65 \\
\hline 65 & 1 & 4 & 21,150 & 64 & 0 & 0 \\
\hline
\end{tabular}

Case Processing Summary

\begin{tabular}{|c|c|c|c|c|c|c|}
\hline & \multicolumn{6}{|c|}{ Cases } \\
\hline & \multicolumn{2}{|c|}{ Valid } & \multicolumn{2}{|c|}{ Missing } & \multicolumn{2}{|c|}{ Total } \\
\hline & $\mathrm{N}$ & Percent & $\mathrm{N}$ & Percent & $\mathrm{N}$ & Percent \\
\hline $\begin{array}{l}\text { Empresa * Cluster } \\
\text { Number of Case }\end{array}$ & 66 & $100,0 \%$ & 0 &, $0 \%$ & 66 & $100,0 \%$ \\
\hline
\end{tabular}




\section{ANEXOS}

ANEXO A - QUESTÕES RELEVANTES PARA O ESTUDO

ANEXO B - VALORES DAS DIMENSÕES DE HOFSTEDE DOS PAÍSES EXISTENTES NA AMOSTRA 


\section{ANEXO A - QUESTÕES RELEVANTES PARA O ESTUDO}

\section{Extrato do Questionário aplicado às Subsidiárias de Empresas Multinacionais Brasileiras}

Em que país está localizada a subsidiária:

Qual o escopo geográfico de suas operações? (ex. onde seus clientes estão localizados?).

\begin{tabular}{|l|l|}
\hline & Exclusivamente no país \\
\hline & América Latina \\
\hline & América do Norte \\
\hline & Leste Europeu \\
\hline & Europa \\
\hline & Ásia \\
\hline & Oriente Médio \\
\hline & África \\
\hline
\end{tabular}

Como a subsidiária foi formada? (circule o número correspondente)

Uma companhia local foi adquirida pela multinacional brasileira Investimento direto - greenfield operation (ex. nova empresa criada) Alianças e Joint-Ventures

Como as relações com organizações específicas têm influenciado o desenvolvimento das competências distintivas da sua subsidiária? (Por favor, use uma escala de 1 "nenhuma influência" a 5 "influência muito alta") nenhuma influência influência

\begin{tabular}{|l|l|l|l|l|l|}
\hline A matriz localizada no Brasil & 1 & 2 & 3 & 4 & 5 \\
\hline Outras subsidiárias da empresa no exterior & 1 & 2 & 3 & 4 & 5 \\
\hline Clientes corporativos preferenciais no país & 1 & 2 & 3 & 4 & 5 \\
\hline Clientes de mercado específicos & 1 & 2 & 3 & 4 & 5 \\
\hline Fornecedores corporativos preferenciais no país & 1 & 2 & 3 & 4 & 5 \\
\hline Fornecedores de mercado específicos & 1 & 2 & 3 & 4 & 5 \\
\hline Universidades ou institutos de pesquisa específicos & 1 & 2 & 3 & 4 & 5 \\
\hline Competidores específicos & 1 & 2 & 3 & 4 & 5 \\
\hline Unidade de P\&D corporativa (no exterior) & 1 & 2 & 3 & 4 & 5 \\
\hline Unidades de P\&D de outras empresas & 1 & 2 & 3 & 4 & 5 \\
\hline Empresas de engenharia de outras empresas & 1 & 2 & 3 & 4 & 5 \\
\hline Instituições governamentais & 1 & 2 & 3 & 4 & 5 \\
\hline
\end{tabular}

Com que extensão as seguintes atividades ocorreram em sua subsidiária nos últimos anos. Nunca

\begin{tabular}{|l|l|l|l|l|l|}
\hline $\begin{array}{l}\text { Novos produtos desenvolvidos no mercado nacional e } \\
\text { então vendidos internacionalmente }\end{array}$ & 1 & 2 & 3 & 4 & 5 \\
\hline Ampliação da responsabilidade Internacional existente & 1 & 2 & 3 & 4 & 5 \\
\hline Resultados bem sucedidos dos investimentos no país & 1 & 2 & 3 & 4 & 5 \\
\hline Transferência do processo de produção para o país & 1 & 2 & 3 & 4 & 5 \\
\hline Aquisição de companhias nacionais conduzidas pela subsidiária & 1 & 2 & 3 & 4 & 5 \\
\hline Atividades inovadoras de negócio internacional criadas no país & 1 & 2 & 3 & 4 & 5 \\
\hline $\begin{array}{l}\text { Expansão da linha de produtos que já eram vendidas } \\
\text { internacionalmente }\end{array}$ & 1 & 2 & 3 & 4 & 5 \\
\hline $\begin{array}{l}\text { Novos investimentos corporativos em P\&D ou em processos } \\
\text { produtivos obtidos pela subsidiária }\end{array}$ & 1 & 2 & 3 & 4 & 5 \\
\hline $\begin{array}{l}\text { Reconfiguração das operações nacionais de uma orientação } \\
\text { doméstica para orientação internacional }\end{array}$ & 1 & 2 & 3 & 4 & 5 \\
\hline
\end{tabular}


Para implementar uma atividade desenvolvida pela matriz, assinale sua concordância ou discordância para as seguintes atividades realizadas por sua subsidiária

\begin{tabular}{|c|c|c|c|c|c|}
\hline \multicolumn{5}{|c|}{$\begin{array}{c}\text { Discordo } \\
\text { plenamente }\end{array}$} & $\begin{array}{l}\text { concordo } \\
\text { plenamente }\end{array}$ \\
\hline Realizamos reuniões com os executivos principais da matriz & 1 & 2 & 3 & 4 & 5 \\
\hline Seguimos manuais de orientação e implementação & 1 & 2 & 3 & 4 & 5 \\
\hline Recebemos executivos brasileiros & 1 & 2 & 3 & 4 & 5 \\
\hline Realizamos treinamentos na matriz & 1 & 2 & 3 & 4 & 5 \\
\hline Realizamos viagens para a matriz & 1 & 2 & 3 & 4 & 5 \\
\hline Apenas recebemos a ordem e implementamos da nossa maneira & 1 & 2 & 3 & 4 & 5 \\
\hline Existe um benchmarking interno na matriz & 1 & 2 & 3 & 4 & 5 \\
\hline Criamos um banco de melhores práticas & 1 & 2 & 3 & 4 & 5 \\
\hline Contratamos consultores especializados & 1 & 2 & 3 & 4 & 5 \\
\hline $\begin{array}{l}\text { Recebemos uma equipe de projetos da matriz responsável } \\
\text { somente pela implementação }\end{array}$ & & & & & \\
\hline
\end{tabular}

Quando sua subsidiária cria alguma inovação ou competência que é transferida para a matriz, assinale sua concordância ou discordância para as seguintes atividades desempenhadas.

\begin{tabular}{|c|c|c|c|c|c|}
\hline \multicolumn{5}{|c|}{$\begin{array}{l}\text { Discordo } \\
\text { plenamente }\end{array}$} & \multirow{2}{*}{ 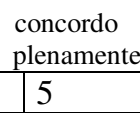 } \\
\hline Realizamos reuniões com os executivos principais da matriz & 1 & 2 & 3 & 4 & \\
\hline Criamos manuais para orientar a implementação & 1 & 2 & 3 & 4 & 5 \\
\hline Alocamos executivos para a matriz ou outra subsidiária & 1 & 2 & 3 & 4 & 5 \\
\hline Ministramos treinamentos na matriz & 1 & 2 & 3 & 4 & 5 \\
\hline Realizamos viagens para a matriz & 1 & 2 & 3 & 4 & 5 \\
\hline Existe um benchmarking interno na matriz & 1 & 2 & 3 & 4 & 5 \\
\hline $\begin{array}{l}\text { Apenas damos a ordem e a implementação é por conta da matriz } \\
\text { da nossa maneira }\end{array}$ & 1 & 2 & 3 & 4 & 5 \\
\hline Criamos um banco de melhores práticas & 1 & 2 & 3 & 4 & 5 \\
\hline Contratamos consultores especializados & 1 & 2 & 3 & 4 & 5 \\
\hline $\begin{array}{l}\text { Alocamos uma equipe de projetos da matriz responsável } \\
\text { somente pela implementação }\end{array}$ & & & & & \\
\hline
\end{tabular}

$\mathrm{Na}$ tentativa de transferir o conhecimento e best practices da sua subsidiária para a matriz ou para as outras subsidiárias, assinale sua concordância para as barreiras enfrentadas nessa tarefa

\begin{tabular}{|c|c|c|c|c|c|}
\hline \multicolumn{5}{|c|}{$\begin{array}{c}\text { Discordo } \\
\text { plenamente }\end{array}$} & \multirow{2}{*}{$\begin{array}{l}\begin{array}{l}\text { concordo } \\
\text { plenamente }\end{array} \\
5\end{array}$} \\
\hline $\begin{array}{l}\text { Dificuldade para integrar e aplicar as } \\
\text { atividades devido à resistência da cultura organizacional }\end{array}$ & 1 & 2 & 3 & 4 & \\
\hline $\begin{array}{l}\text { Turnover dos empregados-chave responsáveis } \\
\text { pela função de transferência }\end{array}$ & 1 & 2 & 3 & 4 & 5 \\
\hline $\begin{array}{l}\text { Crença de que a atividade não era importante e sua transferência } \\
\text { não originava melhorias de eficiência para a corporação }\end{array}$ & 1 & 2 & 3 & 4 & 5 \\
\hline $\begin{array}{l}\text { O compartilhamento da atividade não foi bem visto pois } \\
\text { demandava a alocação de tempo, pessoal e recursos para } \\
\text { benefício de outras unidades }\end{array}$ & 1 & 2 & 3 & 4 & 5 \\
\hline Receio de perder o poder do controle daquela atividade & 1 & 2 & 3 & 4 & 5 \\
\hline $\begin{array}{l}\text { Os incentivos relacionados com a performance não estimulavam } \\
\text { o compartilhamento do conhecimento }\end{array}$ & 1 & 2 & 3 & 4 & 5 \\
\hline $\begin{array}{l}\text { A estrutura hierárquica levou a distorções na } \\
\text { transmissão da atividade }\end{array}$ & 1 & 2 & 3 & 4 & 5 \\
\hline $\begin{array}{l}\text { Síndrome do "não inventado aqui”, ou seja, a matriz } \\
\text { ou as outras subsidiárias apresentavam forte } \\
\text { relutância em aceitar a atividade criada na sua subsidiária }\end{array}$ & 1 & 2 & 3 & 4 & 5 \\
\hline
\end{tabular}


$\mathrm{Na}$ tentativa de transferir o conhecimento e best practices da matriz ou outras subsidiárias para sua subsidiária, assinale sua concordância para as barreiras enfrentadas nessa tarefa

\begin{tabular}{|c|c|c|c|c|c|}
\hline \multicolumn{5}{|c|}{$\begin{array}{l}\text { Discordo } \\
\text { plenamente }\end{array}$} & \multirow{2}{*}{$\begin{array}{l}\begin{array}{l}\text { concordo } \\
\text { plenamente }\end{array} \\
5\end{array}$} \\
\hline $\begin{array}{l}\text { Dificuldade para integrar e aplicar as } \\
\text { atividades devido à resistência da cultura organizacional }\end{array}$ & 1 & 2 & 3 & 4 & \\
\hline $\begin{array}{l}\text { Turnover dos empregados-chave responsáveis } \\
\text { pela função de transferência }\end{array}$ & 1 & 2 & 3 & 4 & 5 \\
\hline $\begin{array}{l}\text { Crença de que a atividade não era importante e sua transferência } \\
\text { não originava melhorias de eficiência para a corporação }\end{array}$ & 1 & 2 & 3 & 4 & 5 \\
\hline $\begin{array}{l}\text { O compartilhamento da atividade não foi bem visto pois } \\
\text { demandava a alocação de tempo, pessoal e recursos para } \\
\text { benefício de outras unidades }\end{array}$ & 1 & 2 & 3 & 4 & 5 \\
\hline Receio de perder o poder do controle daquela atividade & 1 & 2 & 3 & 4 & 5 \\
\hline $\begin{array}{l}\text { Os incentivos relacionados com a performance não estimulavam } \\
\text { o compartilhamento do conhecimento }\end{array}$ & 1 & 2 & 3 & 4 & 5 \\
\hline $\begin{array}{l}\text { A estrutura hierárquica levou a distorções na } \\
\text { transmissão da atividade }\end{array}$ & 1 & 2 & 3 & 4 & 5 \\
\hline $\begin{array}{l}\text { Síndrome do "não inventado aqui”, ou seja, a matriz } \\
\text { ou as outras subsidiárias apresentavam forte } \\
\text { relutância em aceitar a atividade criada na sua subsidiária }\end{array}$ & 1 & 2 & 3 & 4 & 5 \\
\hline
\end{tabular}

Em relação às características do país em que sua subsidiária se encontra, assinale as alternativas abaixo

\begin{tabular}{|c|c|c|c|c|c|}
\hline & \multicolumn{3}{|c|}{$\begin{array}{l}\text { Discordo } \\
\text { plenamente }\end{array}$} & \multicolumn{2}{|c|}{$\begin{array}{r}\text { concordo } \\
\text { plenamente }\end{array}$} \\
\hline $\begin{array}{l}\text { No dia-dia do trabalho todas as pessoas tem suas funções e } \\
\text { responsabilidades muito bem definidas }\end{array}$ & 1 & 2 & 3 & 4 & 5 \\
\hline $\begin{array}{l}\text { No dia-dia do trabalho os superiores têm total autoridade e respeito na } \\
\text { determinação das atividades dos seus subordinados }\end{array}$ & 1 & 2 & 3 & 4 & 5 \\
\hline $\begin{array}{l}\text { Os subordinados aceitam as atividades e responsabilidades que } \\
\text { que o superior determina }\end{array}$ & 1 & 2 & 3 & 4 & 5 \\
\hline $\begin{array}{l}\text { As pessoas na organização acreditam que a maneira de mudar } \\
\text { as políticas internas da organização é pela substituição das pessoas que } \\
\text { estão no poder }\end{array}$ & 1 & 2 & 3 & 4 & 5 \\
\hline $\begin{array}{l}\text { As pessoas enxergam a possibilidade de promoção baseada } \\
\text { nos anos de experiência do empregado como um todo e do empregado } \\
\text { na empresa. }\end{array}$ & 1 & 2 & 3 & 4 & 5 \\
\hline $\begin{array}{l}\text { É normal a pratica de um superior conceder emprego para } \\
\text { um de seus familiares }\end{array}$ & 1 & 2 & 3 & 4 & 5 \\
\hline $\begin{array}{l}\text { As pessoas no ambiente de trabalho são incentivadas, sobretudo, } \\
\text { por metas e resultados }\end{array}$ & 1 & 2 & 3 & 4 & 5 \\
\hline $\begin{array}{l}\text { As pessoas enxergam a competitividade interna como um aspecto } \\
\text { normal, pois a lei é "competir ou morrer }\end{array}$ & 1 & 2 & 3 & 4 & 5 \\
\hline $\begin{array}{l}\text { Os homens são muito mais orientados para o sucesso material e as } \\
\text { metas financeiras }\end{array}$ & 1 & 2 & 3 & 4 & 5 \\
\hline Não é bem visto que as pessoas mostrem suas emoções em público & 1 & 2 & 3 & 4 & 5 \\
\hline .As pessoas dão importância muito alta para a titulação do cargo & 1 & 2 & 3 & 4 & 5 \\
\hline Existem muitas regras que devem ser seguidas fielmente & 1 & 2 & 3 & 4 & 5 \\
\hline $\begin{array}{l}\text { As pessoas não tem opiniões muito contraditórias sobre o que } \\
\text { é bom ou mal }\end{array}$ & 1 & 2 & 3 & 4 & 5 \\
\hline $\begin{array}{l}\text { As pessoas dão importância significativa para } \\
\text { a estabilidade dos eventos e cargos }\end{array}$ & 1 & 2 & 3 & 4 & 5 \\
\hline As pessoas não gostam de informações contraditórias & 1 & 2 & 3 & 4 & 5 \\
\hline
\end{tabular}


ANEXO B - Valores das dimensões de Hofstede dos países existentes na amostra estudada e o Brasil

\begin{tabular}{|lcccc}
\hline País & Distância do Poder & Individualismo & Masculinidade & Controle da incerteza \\
África do Sul & 49 & 65 & 63 & 49 \\
Alemanha & 35 & 67 & 66 & 65 \\
Argentina & 49 & 46 & 56 & 86 \\
Angola & 77 & 20 & 46 & 54 \\
Bolívia & 64 & 12 & 50 & 75 \\
Canadá & 39 & 80 & 52 & 48 \\
Chile & 63 & 23 & 28 & 86 \\
China & 80 & 20 & 66 & 30 \\
Colômbia & 67 & 13 & 64 & 80 \\
Emirados & 80 & 38 & 52 & 68 \\
Equador & 78 & 8 & 63 & 67 \\
Eslováquia & 104 & 52 & 110 & 51 \\
Espanha & 57 & 51 & 42 & 86 \\
Estados Unidos & 40 & 91 & 62 & 46 \\
França & 68 & 71 & 43 & 86 \\
Itália & 50 & 76 & 70 & 75 \\
México & 81 & 30 & 69 & 82 \\
Paraguai & 73 & 26 & 56 & 51 \\
Peru & 64 & 16 & 42 & 87 \\
Portugal & 63 & 27 & 31 & 104 \\
Uruguai & 61 & 36 & 38 & 100 \\
Venezuela & 81 & 12 & 73 & 76 \\
Brasil & 69 & 38 & 49 & 76 \\
Fonte: adaptado de & $50 f 5 t e d$ & & \\
\hline
\end{tabular}

Fonte: adaptado de Hofstede (2001) 